\title{
COUNTERFEITING ROMAN SILVER COINS IN THE 1ST - 3RD CENTURIES A.D. STUDY ON ROMAN PROVINCES FROM MIDDLE DANUBE TO LOWER RHINE
}

\begin{abstract}
The newly written paper for Roman imperial silver coins is expanding the studied area of counterfeited silver coins discovered on archaeological sites by analyzing a hole geographic region stretching from the middle Danube in the East to the shores of the lower Rhine in the West.

Aiming to prove the existence of a centralize pattern regarding silver plated coins distribution, the study expanded its investigation to include the random appearance of hybrid and plated hybrid coins. Besides this the focus will remain on counterfeited pieces, their proportions and distribution, with a smaller case study for the Severian period during when most plated pieces were dated for.

Towards the end of the study new results can finally support previous debated arguments regarding coin distribution and patterns of distribution in frontier provinces, alongside with Rome's approach to silver plated pieces.

Keywords: Roman Empire, silver, coins, Denarius, Antoninianus, numismatics, Dacia, Pannonia, Noricum, Raetia, Germania Superior, Germania Inferior, Gallia Belgica, hybrid, plates, graphs, coefficients.
\end{abstract}

\section{INTRODUCTION}

$\mathbf{T}$

he studied area includes sites from Roman provinces of Dacia, Pannonia, Noricum, Raetia, Germania Superior, Germania Inferior and Gallia Belgica. This layout was chosen because of its geographical and historical background, the Roman Danube and Rhine frontiers being settled in these regions between the I and III centuries A.D.

If we wanted to study the coin finds around these areas it was necessary to study various catalogues regarding Roman coins, to gather all silver denarius and antoninianus pieces and divide the coins by type and issuer's reign. Thus, we have genuine coins officially issued by Rome, plated pieces, hybrid coins and plated hybrid pieces.

Further on, the coins were inserted into graphs to represent the proportion of finds and monetary circulation for each site. After analyzing the sites all data was used to form new graphs which represent the monetary situation at the level of the provinces and regions, finally comparing the two major frontiers Danube vs. Rhine.

In these circumstances it was possible to study the situation of counterfeited and hybrid coins belonging to these areas and make a case study on the Severian period and the counterfeited coins dated at their period.
Răzvan Bogdan Gaspar

University Babeş-Bolyai of Cluj-Napoca gaspar.razvan.bogdan@gmail.com

DOI: $10.14795 /$ j.v5i1.300

ISSN 2360 - 266X

ISSN-L 2360 - 266X 
Chronological, all silver coins from Augustus (27BC14AD) to Philip I (244-249) have been integrated in the study, denarius and antoninianus pieces. This way the "Golden Age" of the Roman Empire and the beginning of the "Downfall" are all recorded in coin finds, as historians can see the progressive debasement of silver coinage for this period.

Also, this period involves the conquest (106 AD) and abandonment (270-275) of Dacia, formation of Roman Pannonia (9 AD), annexation of Noricum, Raetia and Germania Superior during the I century AD and partially abandonment after the Alamanni attack of 250-260.

New historical sites are included in the studied area stretching from Vienna up the Danube and down the Rhine to Nijmegen, being included Roman sites such as Vindobona (Vienna, Austria) and Ovilava (Wels, Austria) situated in Noricum, Sorviodurum (Straubing, Germany), Castra Regina (Regensburg, Germany), Castra Vetoniana (Pfunz, Germany), Ingolstadt (Germany), Abusina (Eining, Germany), Augusta Vindelicorum (Augsburg, Germany) and Aislingen (Germany) for the province of Raetia.

In the case of Germania Superior we have the sites from Bad Cannstatt (Germany), Sumelocenna (Rottenburg am Neckar, Germany), Tabernae (Rheinzabern, Germany), Noviomagus (Speyer, Germany), Heidelberg (Germany), Miltenberg (Germany), Stockstadt (Germany), Nida (Germany), Rückingen (Germany), Friedberg (Germany), Mogontiacum (Mainz, Germany), Hofheim (Germany), Wiesbaden (Germany), Zugmantel (Germany), Heldenbergen (Germany), Ober-Florstadt (Germany) and Butzbach (Germany), Germania Inferior sites from Mariaweiler (Germany), Nörvenich (Germany), Colonia Agrippina (Köln, Germany), Novaesium (Neuss, Germany) and Ulpia Noviomagus (Nijmegen, Holland), also Treverorum (Trier, Germany) located in Gallia Belgica.

All studied sites were later integrated in geographical regions to facilitate the study of counterfeited coin patterns and monetary circulation in the area. Consequently, sites situated in Roman Noricum and Raetia formed the Upper Danube region, sites from Germania Superior are represented by Upper Rhine area and sites from Germania Inferior and Belgica form the Lower Rhine area.

Regarding the chosen chronological time frame, between August (27BC-14AD) and Philip I (244 - 249), the reason behind this was influenced by the local history of the provinces. Dacia was included in the empire on $106 \mathrm{AD}$ and abandoned between 270-275, Pannonia acquired after 9 $\mathrm{AD}$, Noricum during the first half of the I century AD while Germania Superior and Raetia during the Flavian dynasty (70 - 90) and partially abandoned during the Alamanni attack of $250-260 \mathrm{AD}$.

To facilitate the acquisition of more historical information just by using some coin catalogs there were some methodological steps performed. First step was to find the right scientific material that covered the archaeological sites from Roman provinces of Noricum, Raetia, Germania Superior, Germania Inferior and Gallia Belgica, today part of Austria, Germany and the Netherlands.

Second, it was necessary to gather all silver coins dated between the reign of Augustus (27BC-14AD) and that of Philip I (244-249) so that a register could be created. This chronological period was chosen because it represents both the days of glory for The Roman Empire and the beginning of its fall because of the debasement of the silver coins and scarcity of silver in genuine pieces.

Also, during this time frame part of the Roman provinces would go through transformations, Dacia will be integrated in $106 \mathrm{AD}$ and abandoned between 270-275, Pannonia will be added in $9 \mathrm{BC}$, Noricum integrated in the first half of the I century, Raetia and Germania Superior added during the Flavian dynasty (70-90) and partially abandoned after the Alamanni attacks (250-260).

Third, pie charts that show type, number and proportion of coins and graphs that show distribution of the pieces according to the issuer were created for a better representation of the results.

For the fourth step, a modification of the Ravetz formula ${ }^{1}$ was used in order to create monetary coefficients for the study regions. Thus, the used formula was: coins per issuer from all sites years of reign
Using the new formula, it was possible to represent the coin distribution for silver pieces, genuine and plated, on all studied regions regardless of quantity of discovered coins for each particular site.

\section{MONETARY SITUATION ON STUDIED SITES:}

First, we observe the individual sites and discovered silver coins to gather all pieces of the puzzle and asses the information.

Around the year 89 AD, Domitian (81-96) moves Legio XIII Geminae from Poetovio to Vindobona ${ }^{2}$ (Vienna, Austria) where the soldiers raised a new castrum feting for a legion, which in time will become ground zero for the future city of Vienna ${ }^{3}$.

Later Legio XIII Geminae was send to fight with the Dacians at the lower Danube, in her place arriving Legio $X$ Geminae from Nijmegen/Noviomagus which will remain here for the next three centuries ${ }^{4}$.

Using coin catalogs, it was possible to create pie charts and graphs showing the coin distribution on archaeological sites. Thus, for Roman Vindobona Fig. 1 we can see 281 silver coins that were dated between the I and III centuries $\mathrm{AD}^{5}$. From the total number of coins, 187 pieces with a proportion of $67 \%$ are genuine, 66 with a proportion of $23 \%$ are plated, 19 pieces with a proportion of $7 \%$ are plated hybrids and 9 coins representing $3 \%$ are hybrids.

Fig. 2 shows coin distribution based on issuer and his time of reign, the earliest pieces being dated to Vespasian (69-79) and most of genuine coins are dated during the Severian period, especially during the reign of Septimius Severus (193-211), Elagabalus (218-222) and Severus Alexander (222-235). In the case of plated coins most of them have shown on their surface the image of Septimius Severus (193-211).

CASEY 1974, 41.

BÖRNER 2002, 241-252

VICI.ORG/VICI/1936.

MASPOLI 2014

FMRÖ 1978 


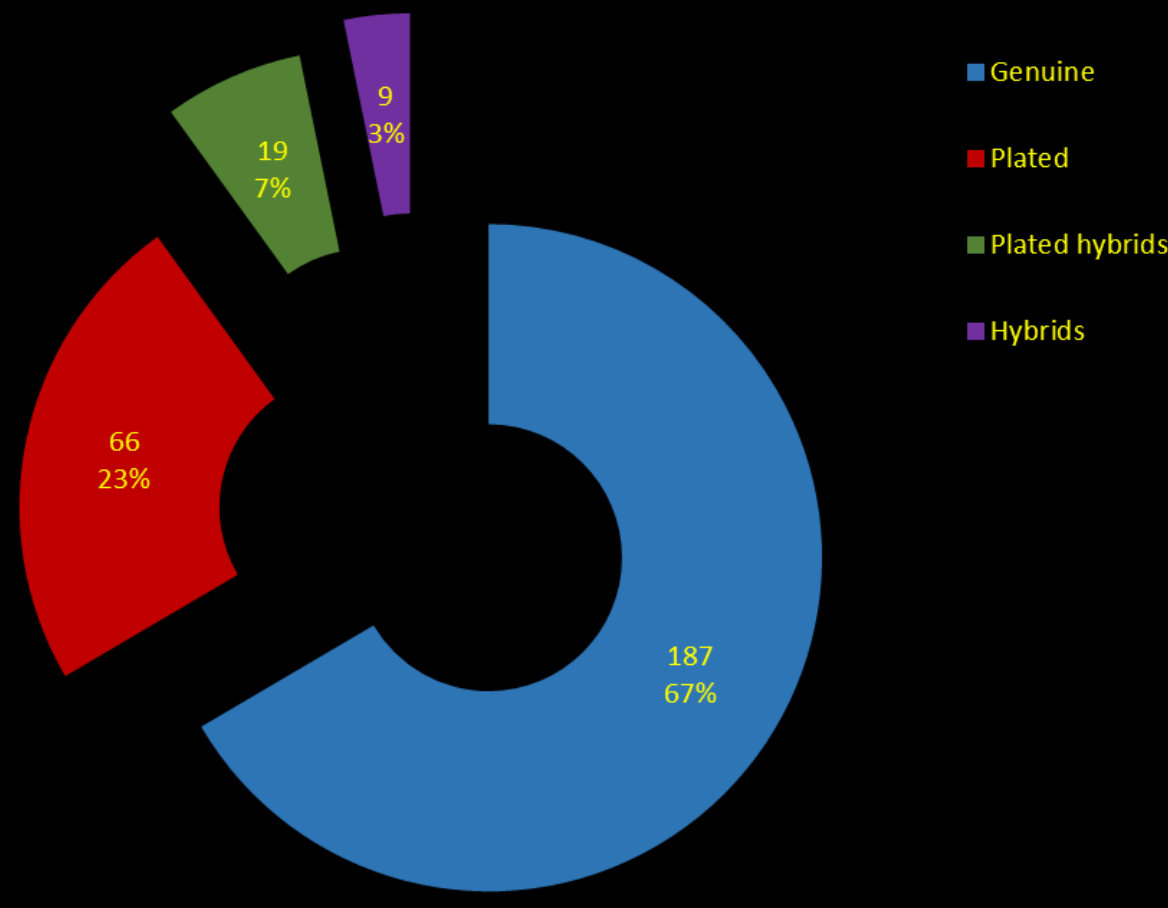

Fig.1. Graph of silver coins from Vindobona - number of coins and their proportion on the site;

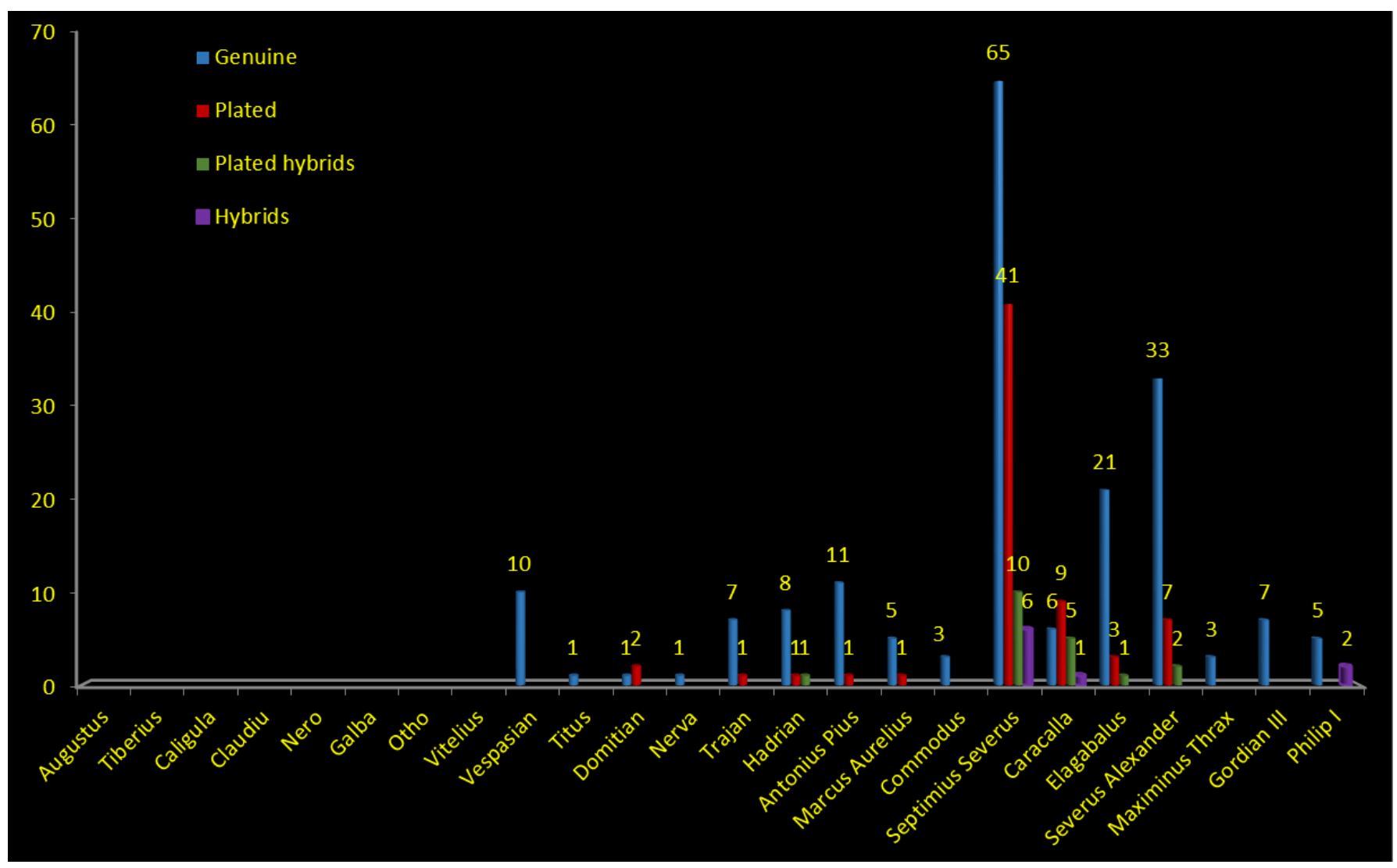

Fig.2. Graph of silver coins from Vindobona - number of pieces for each issuer;

Under the reign of Hadrian (117-138) Ovilava ${ }^{6} \vdots$ (Wels, Austria) will receive the title of Municipium Ovilavis ${ }^{7}$,

${ }_{6}$ VICI.ORG/vici/2884.

7 WINKLER 1981, 61-68. sign that this settlement had a regional importance and it was able to govern the surrounding area by itself ${ }^{8}$.

8 MIGLBAUER 1997, 165. 


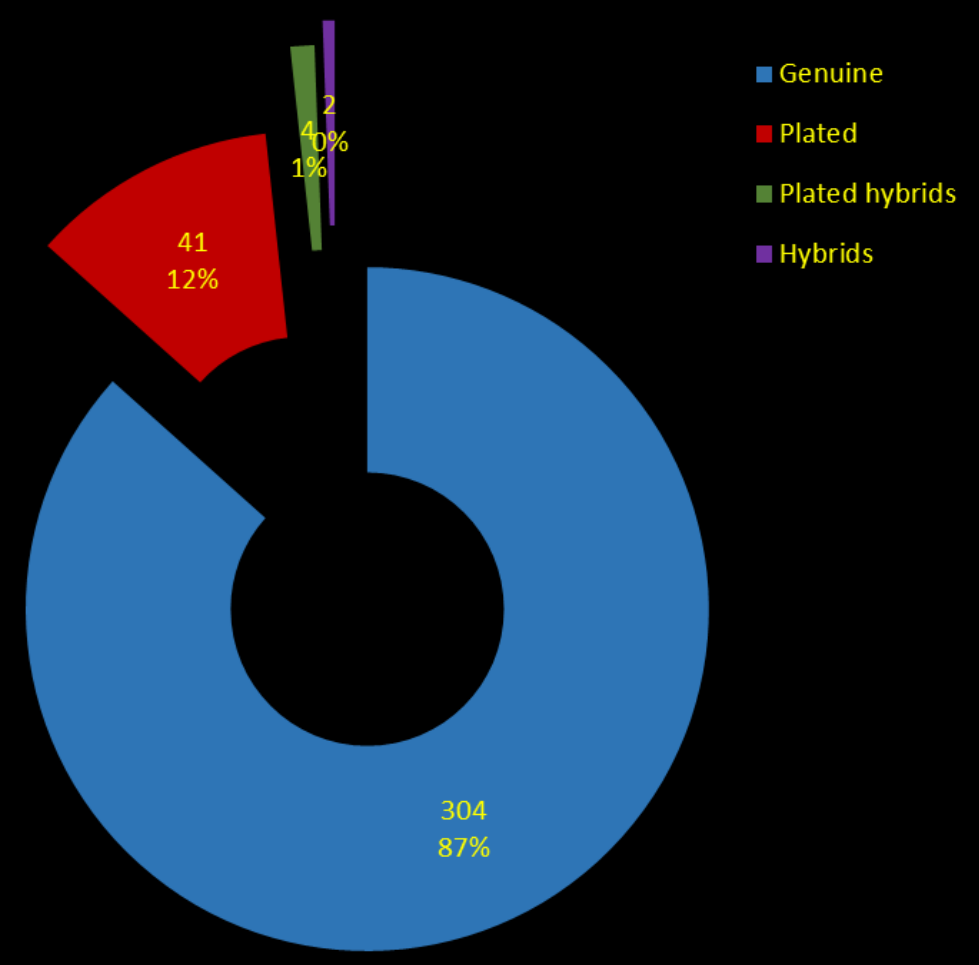

Fig.3. Graph of silver coins from Ovilava - number of coins and their proportion on the site;

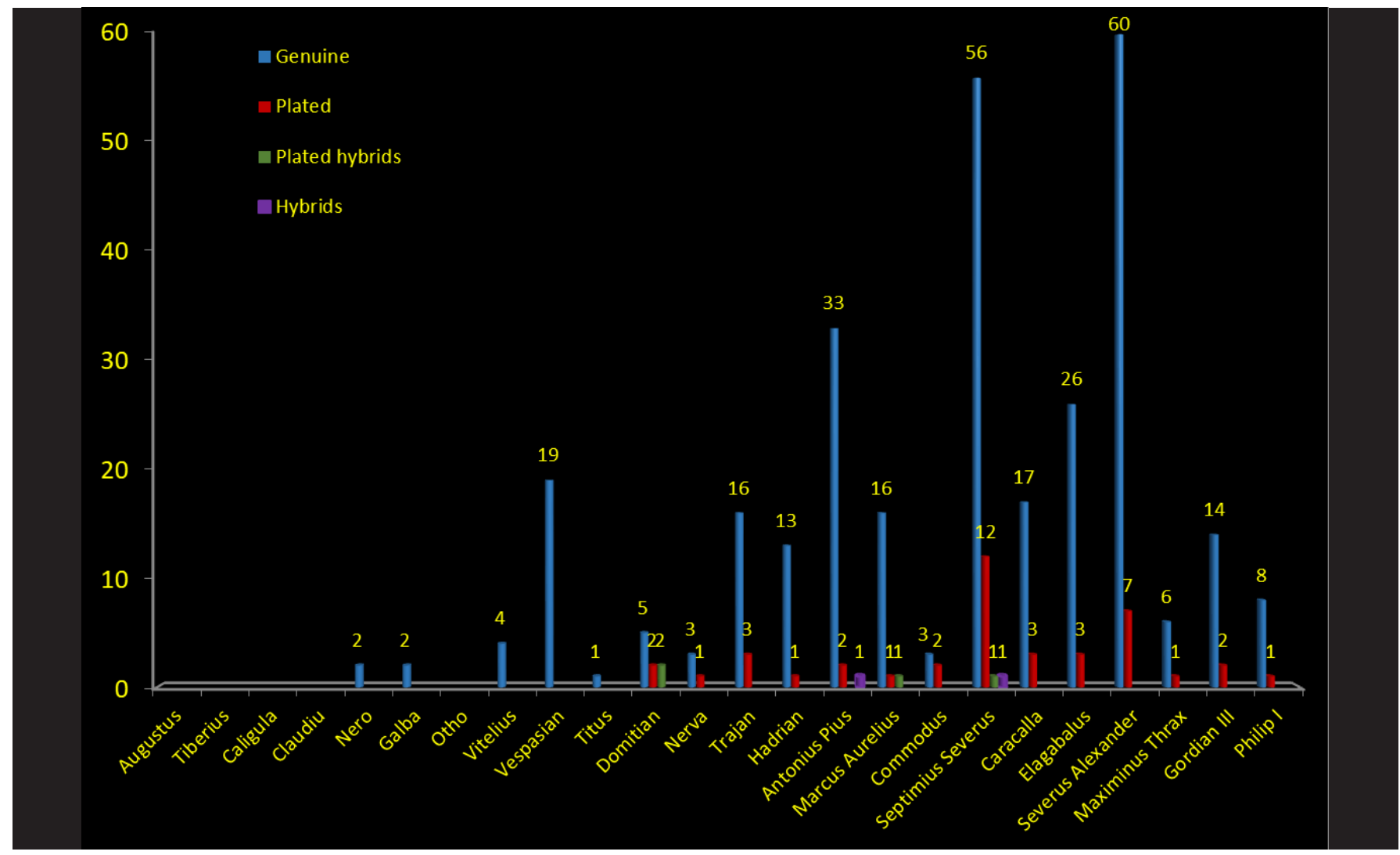

Fig.4. Graph of silver coins from Ovilava - number of pieces for each issuer;

Fig. 3 shows the presence of 351 silver coins ${ }^{9}$ on this site, $87 \%$ from the total number being genuine, $12 \%$ are plated, $1 \%$ identify as plated hybrids and $0,5 \%$ are hybrids.

9 VONDROVEC 2003.
As we can see in Fig. 4, genuine coins are represented more for the reign of Vespasian (69-79) and during the Antoninian and Severian dynasty, especially Antoninus Pius (138-161), Septimius Severus (193-211) and Severus 


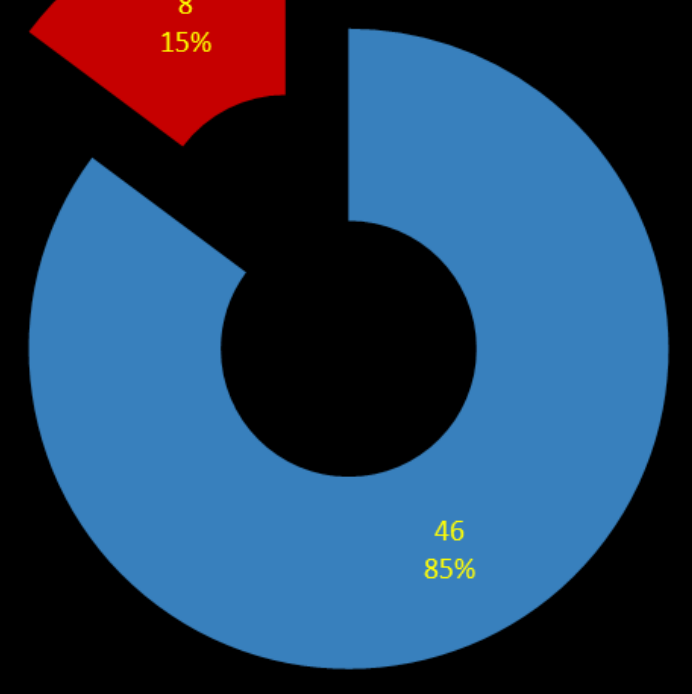

$15 \%$

Fig.5. Graph of silver coins from Sorviodurum - number of coins and their proportion on the site;

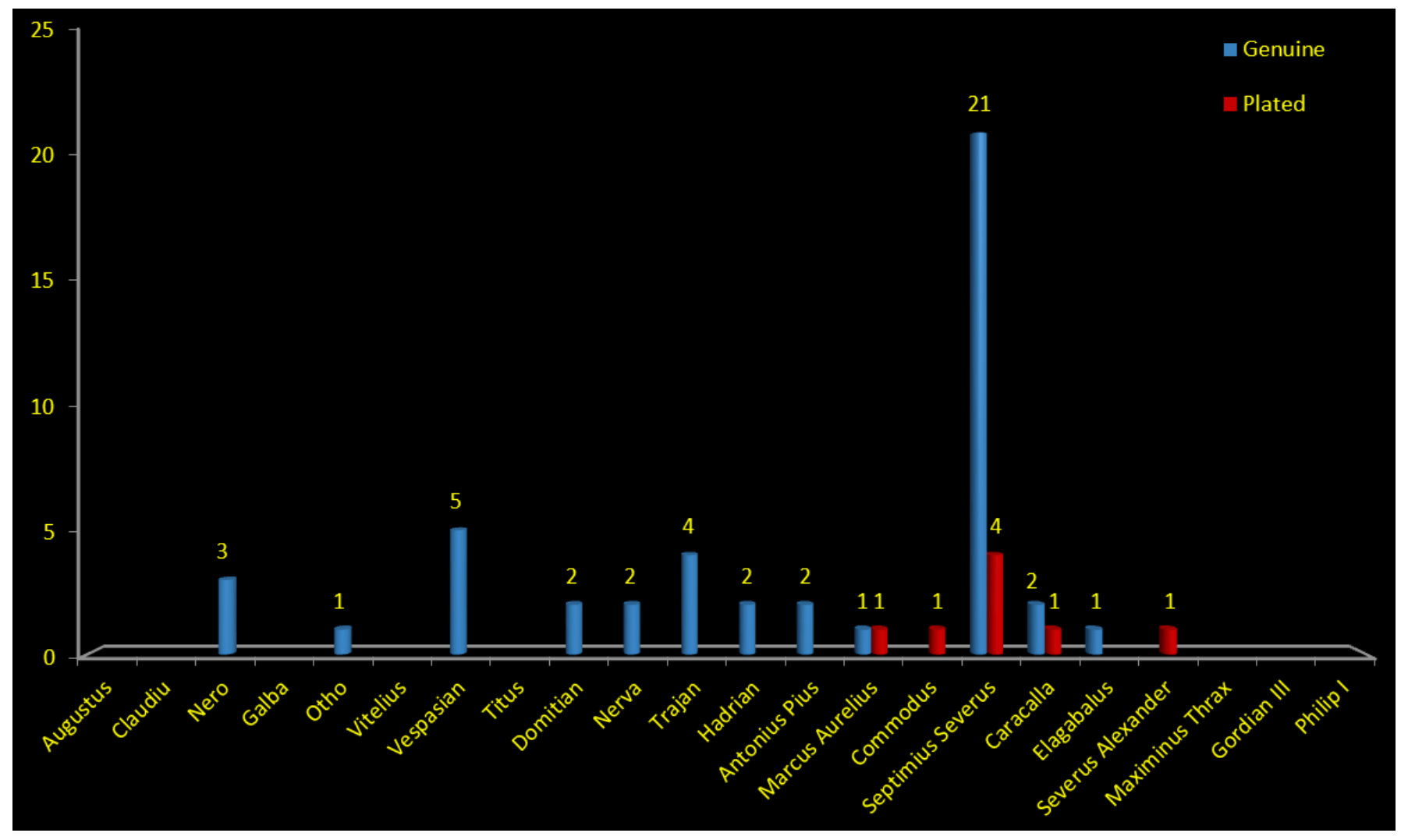

Fig.6 - Graph of silver coins from Sorviodurum - number of pieces for each issuer;

Alexander (222-235).

At Sorviodurum (Straubing, Germany) was the site of a Roman military camp ${ }^{10}$, which served as a strategic point along the Danube frontier for the I century $\mathrm{AD}^{11}$. The military camp served as garrison for Cohors III Batavorum 10 VICI.ORG/vici/7263.

11 WALKE 1965, 9-17. PRAMMER 1989, 6-7, 14-16. equitata milliaria ${ }^{12}$ and later for Cohors I Flavia Canathenorum milliaria sagittariorum ${ }^{13}$. Alongside the camp was a military harbor which most likely was used from Vespasian (69-79) to Trajan (98-117) or Hadrian (117-138) ${ }^{14}$.

2 PRAMMER 1989, 22-29. AE 1995, 1185.

13 AE 2005/1152. CIL III/11976. AE 2005/1153. SCHÖNBERGER 1985, 457.

14 PRAMMER 1989, 73-78. 


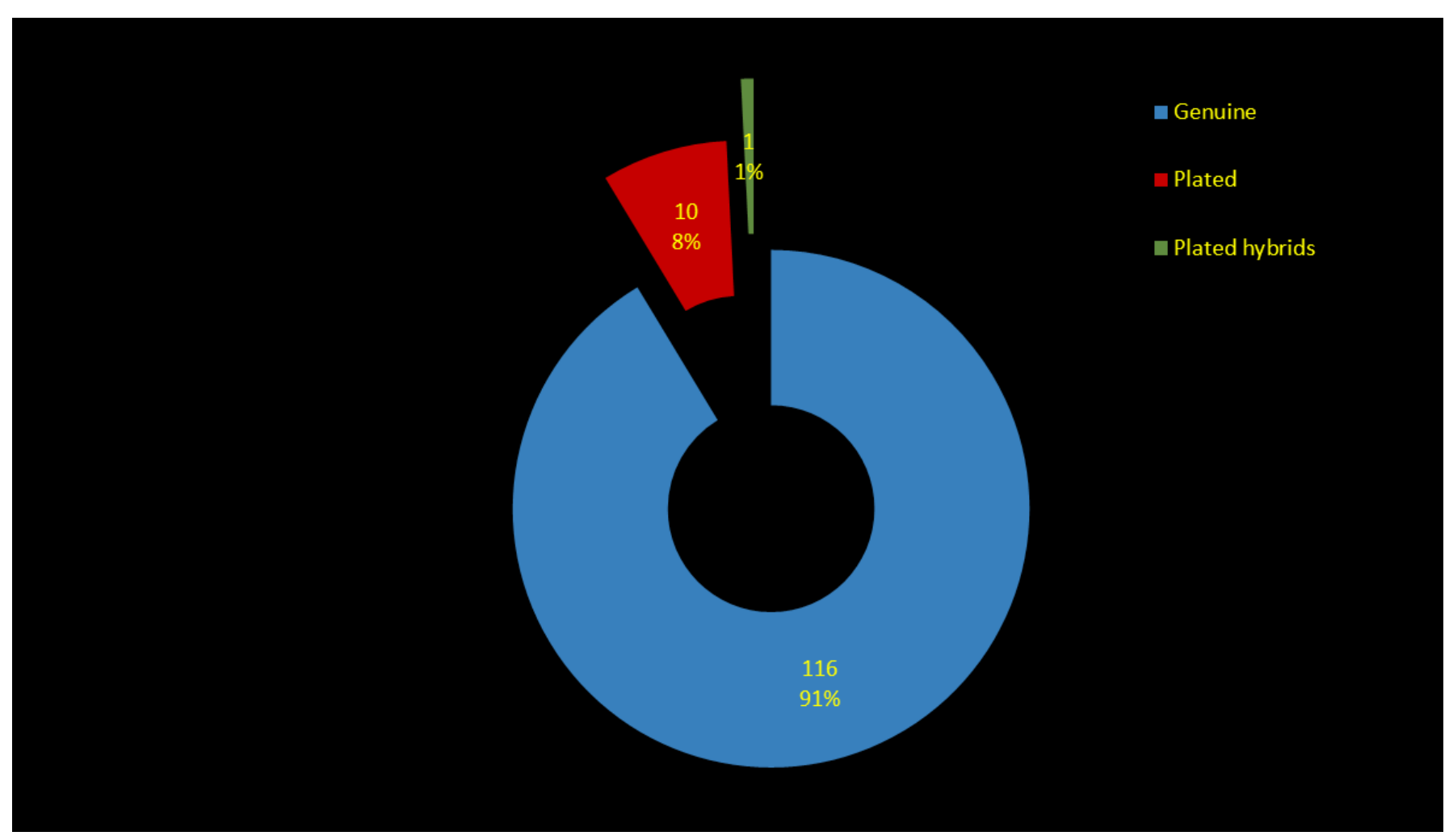

Fig.7. Graph of silver coins from Castra Regina - number of coins and their proportion on the site;

For this location, there have been identified 54 silver coins $^{15}$ from witch 46 pieces representing $85 \%$ are genuine and 8 coins with a proportion of $15 \%$ are plated, as seen in Fig. 5.

We have coins dated under many issuers, Fig. 6, most of them are showing images dated under Septimius Severus (193-211).

Castra Regina (Regensburg, Germany) was a Roman legionary camp, situated on the shores of the Danube which expanded and established the foundation for the future town of Regensburg ${ }^{16}$. It served as garrison for Legio III Italica ${ }^{17}$ which was brought here to protect this area of the limes.

There have been discovered 127 silver coins ${ }^{18}$ as seen in Fig. 7, from which 116 representing $91 \%$ are genuine, 10 pieces with $8 \%$ are plated and one coin representing $1 \%$ is a plated hybrid.

Also, we can see in Fig. 8 that most of the genuine pieces have been dated for Vespasian (69-79), Severian dynasty and the beginning of the Military Anarchy period.

Roman camp of Castra Vetoniana ${ }^{19}$ (Pfunz, Germany) was a cavalry camp erected around year 90 $\mathrm{AD}^{20}$. Here were identified 57 silver pieces ${ }^{21}$ as seen in Fig. 9. From the total number of coins 52 with a proportion of $91 \%$ are genuine, four pieces with $7 \%$ are plated and one coin representing $2 \%$ is hybrid.

Also, we can observe how these pieces were dated for

\footnotetext{
15 FMRD 1970, 152.

16 Vici.Org/vici/9829.

17 STROBEL 1999. ANTIKEFAN.DE/REGENSBURG. LIPPOLD 1979, 21-35.

18 FMRD 1978, 51.

19 VICI.ORG/vici/4435.

20 FASSBINDER 2008, 163

21 FMRD 1963, 60.
}

the II and III centuries AD, Fig. 10, most of them being dated for Septimius Severus (193-211), Elagabalus (218-222) and Severus Alexander (222-235).

At 6 kilometers south from modern Ingolstadt (Germany), there have been identified three Roman military camps dated at the I century $\mathrm{AD}^{22}$, unfortunately because of the movement of the shapeshifting Danube and modern rock excavations most of their layout was destroyed ${ }^{23}$.

Fortunately, there have been discovered 53 genuine silver coins ${ }^{24}$ as shown in Fig. 11. These coins were arranged in order of represented issuer, and as seen in Fig. 12 the majority of them were dated to Septimius Severus (193211).

At Eining (Germany) was a castrum ${ }^{25}$ for a cavalry unit which's aim was to control the eastern area of the limes for this region ${ }^{26}$. Constructed under Titus (79-81) by Cohors IIII Gallorum using wood and earth elements ${ }^{27}$.

Later towards the end of Trajan's reign (98-117) the unit was replaced by a detachment of Cohors II Tungrorum milliaria equitata ${ }^{28}$. Around AD 153 Cohors III Britannorum equitata was brought here and helped raise the stone phase of the castrum under Antoninus Pius (138-161), place where the horseman remained until late antiquity ${ }^{29}$.

Thus in Fig. 13 we can observe the 172 silver pieces ${ }^{30}$ discovered at Eining, 161 of them representing 94\% are genuine, nine coins representing $5 \%$ are plated while two

\footnotetext{
2 HÜSSEN 1995, 95-110.

23 VICI.ORG/vici/16449.

${ }^{24}$ FMRD 1960.

25 JÄGER 1993.

26 VICI.ORG/vici/4438.

27 FMRD 1970, 47.

28 GSCHWIND 2004.

29 COH-II-RAET.DE.

${ }_{30}$ FMRD 1970.
} 


\section{Studies}

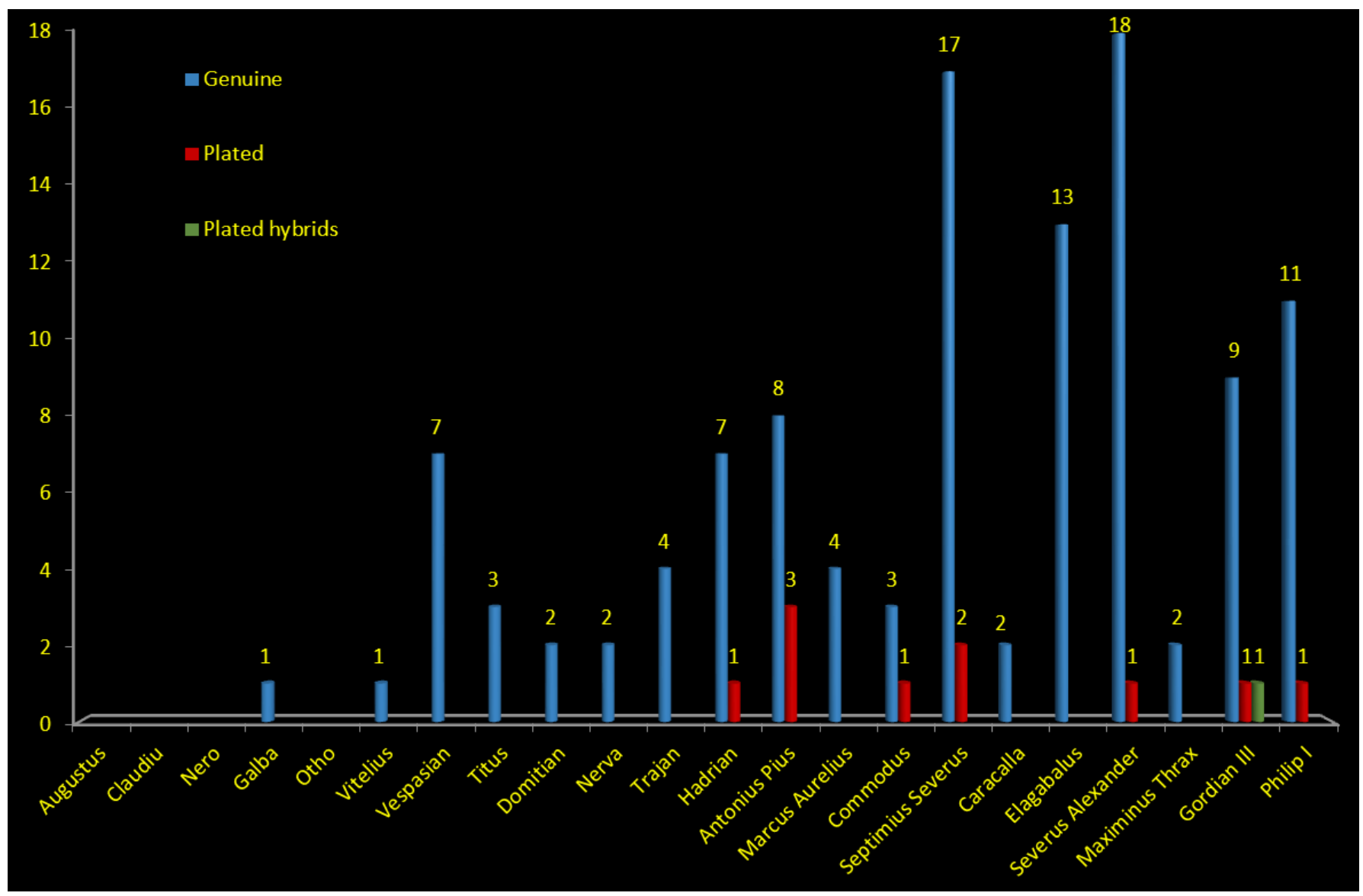

Fig.8. Graph of silver coins from Castra Regina - number of pieces for each issuer;

coins which represent $1 \%$ are hybrids.

Also, in Fig. 14 we can see how many of the coins were dated during the reign of Septimius Severus (193-211),
Elagabalus (218-222) and Severus Alexander (222-235). Augusta Vindelicorum ${ }^{31}$ (Augsburg, Germany) was a Roman town originating during the reign of Augustus

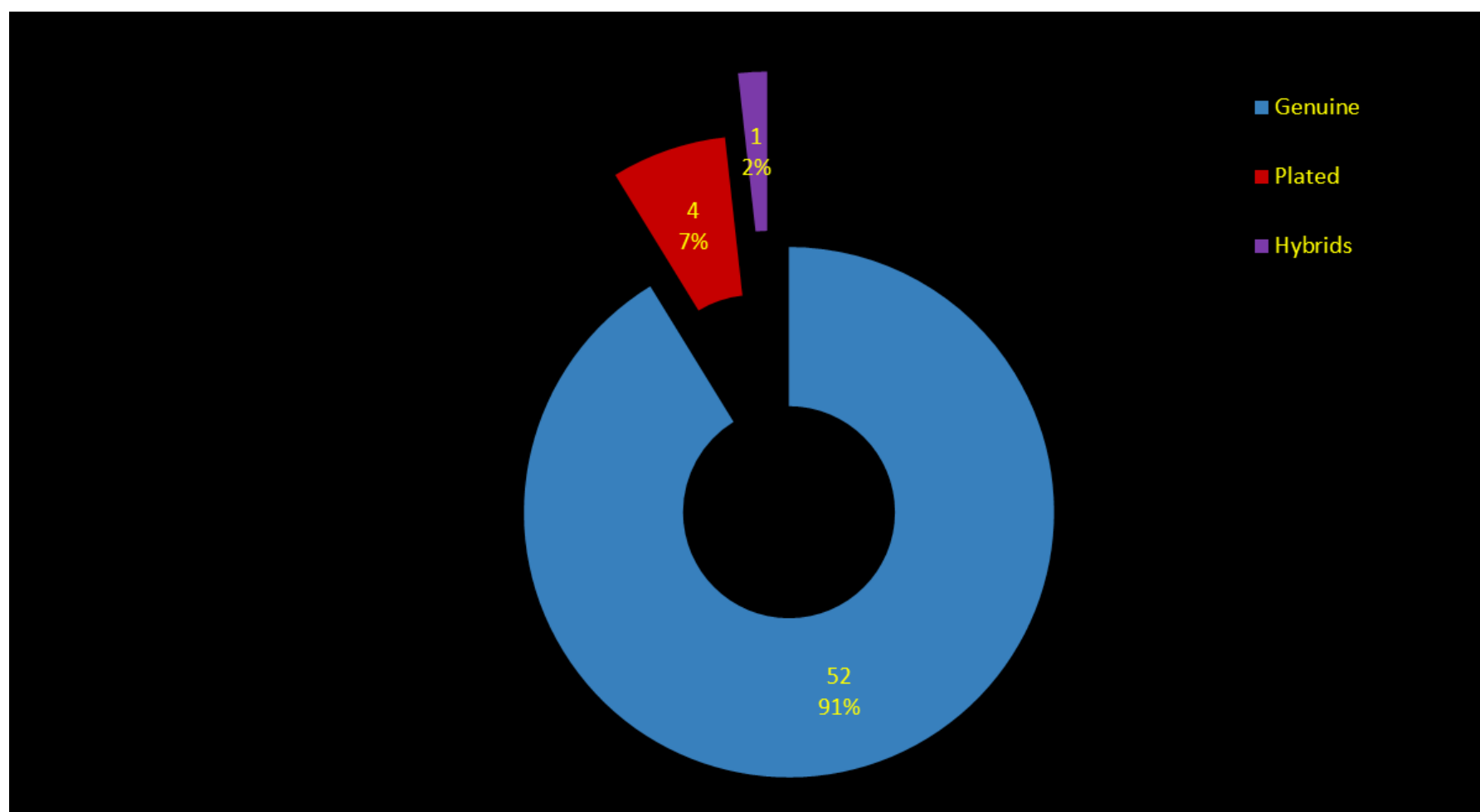

Fig.9. Graph of silver coins from Castra Vetoniana - number of coins and their proportion on the site;

$$
\text { : } 31 \text { VICI.ORG/vici/22884. }
$$




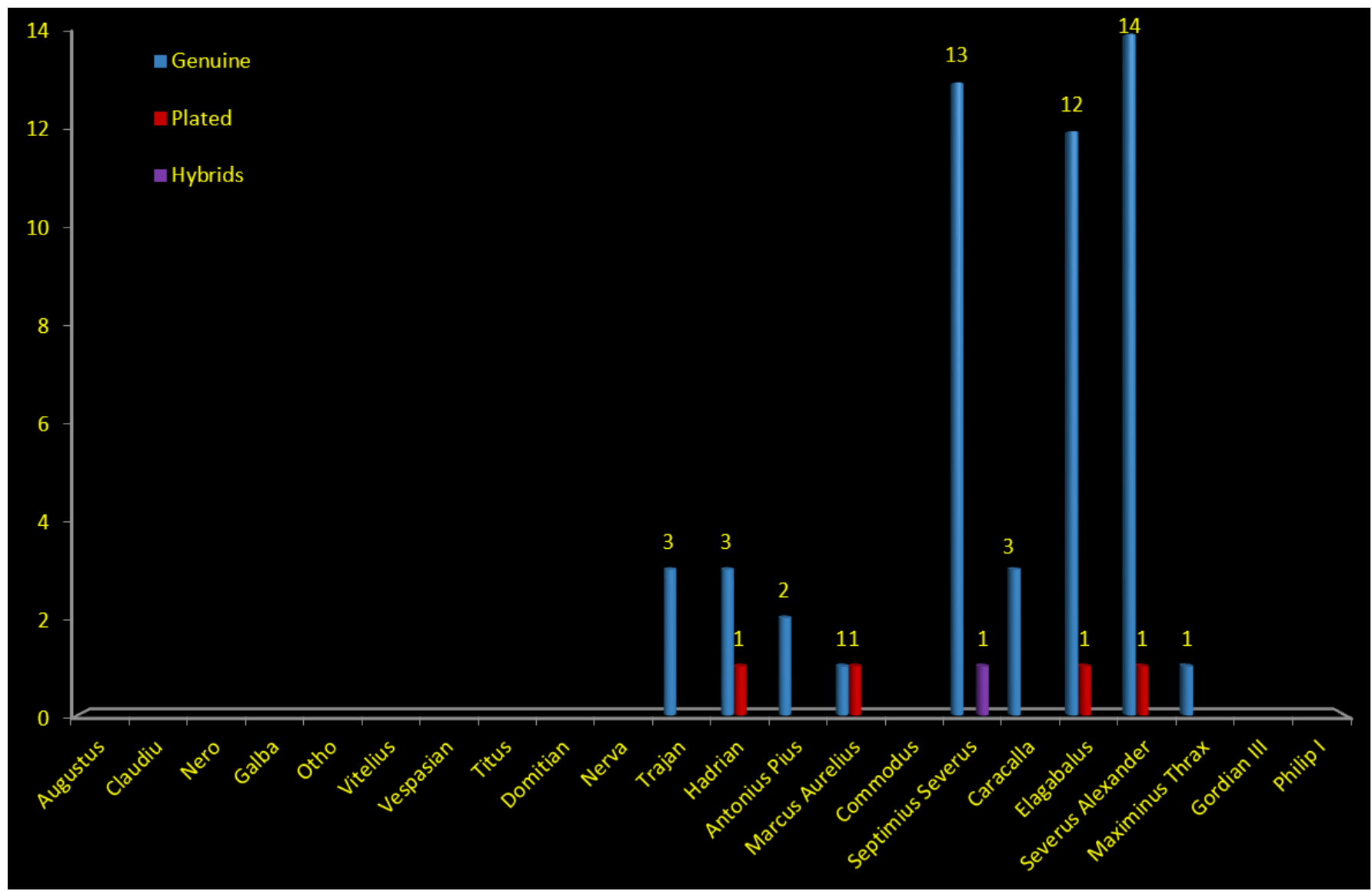

Fig.10. Graph of silver coins from Castra Vetoniana - number of pieces for each issuer;

口 Genuine

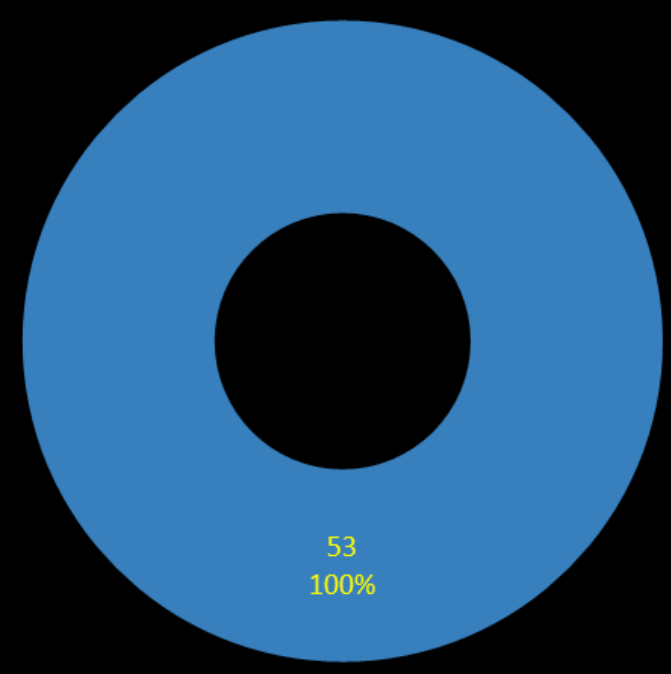

Fig.11. Graph of silver coins from Ingolstadt - number of coins and their proportion on the site;

(27 BC-AD 14) when the entire region was conquered by the romans and here was constructed a military camp ${ }^{32}$.

Later the settlement will continue to grow so that in 121 AD during the reign of Hadrian (117-138) the town will receive the rank of Municipium under the name of Municipium

\footnotetext{
32 ROECK 2005. VICI.ORG/vici/22858.
}

Aelium Augustum ${ }^{33}$.

In the case of silver pieces discovered at Augusta Vindelicorum, there have been discovered 120 coins $^{34}$ as seen in Fig. 15, from which 113 representing 94\% are genuine, six pieces representing $5 \%$ are plated and one coin representing 33 FMRD 1962.

${ }^{34}$ FMRD 1962, 31. 


\section{Studies}

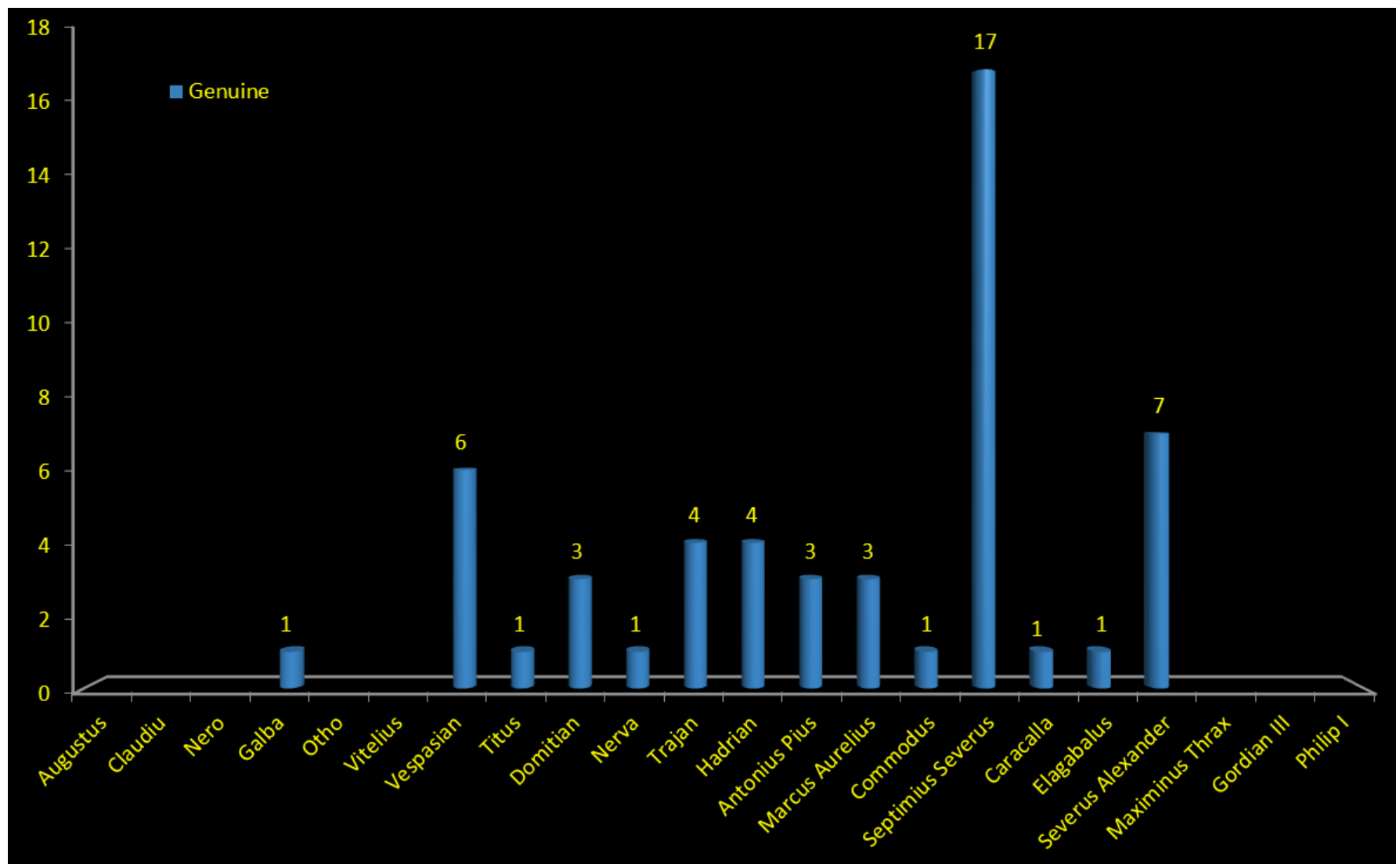

Fig.12. Graph of silver coins from Ingolstadt - number of pieces for each issuer;

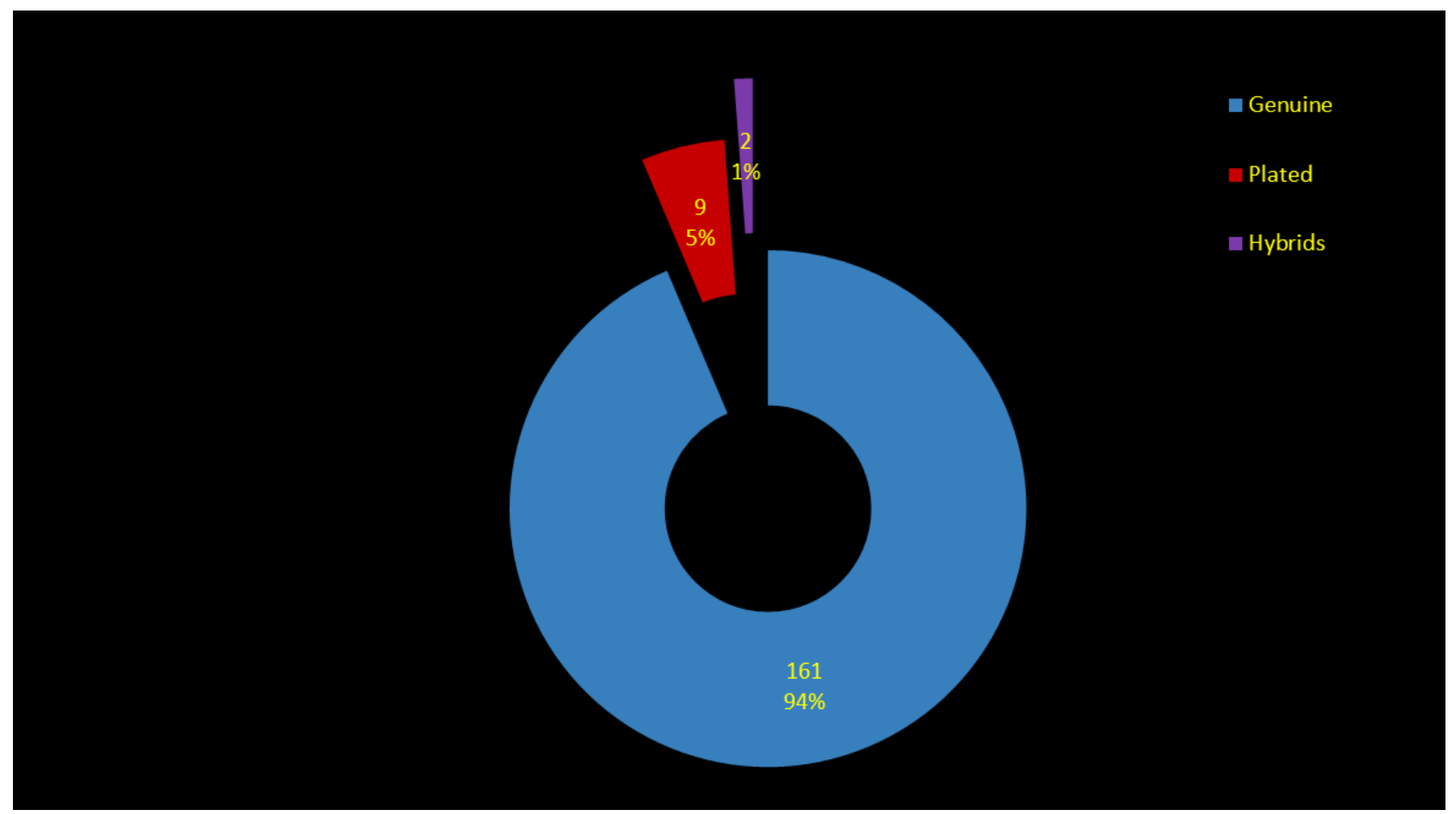

Fig.13. Graph of silver coins from Eining - number of coins and their proportion on the site;

\section{$1 \%$ is hybrid.}

On the other hand, in Fig. 16 we can observe that most of the pieces were representing images dated during the reign of Vespasian (69-79), Trajan (98-117), Septimius
Severus (193-211) and Severus Alexander (222-235). Also, the few identified silver plated coins were dated for the Severian dynasty.

Roman fort of Aislingen (Germany) was constructed 


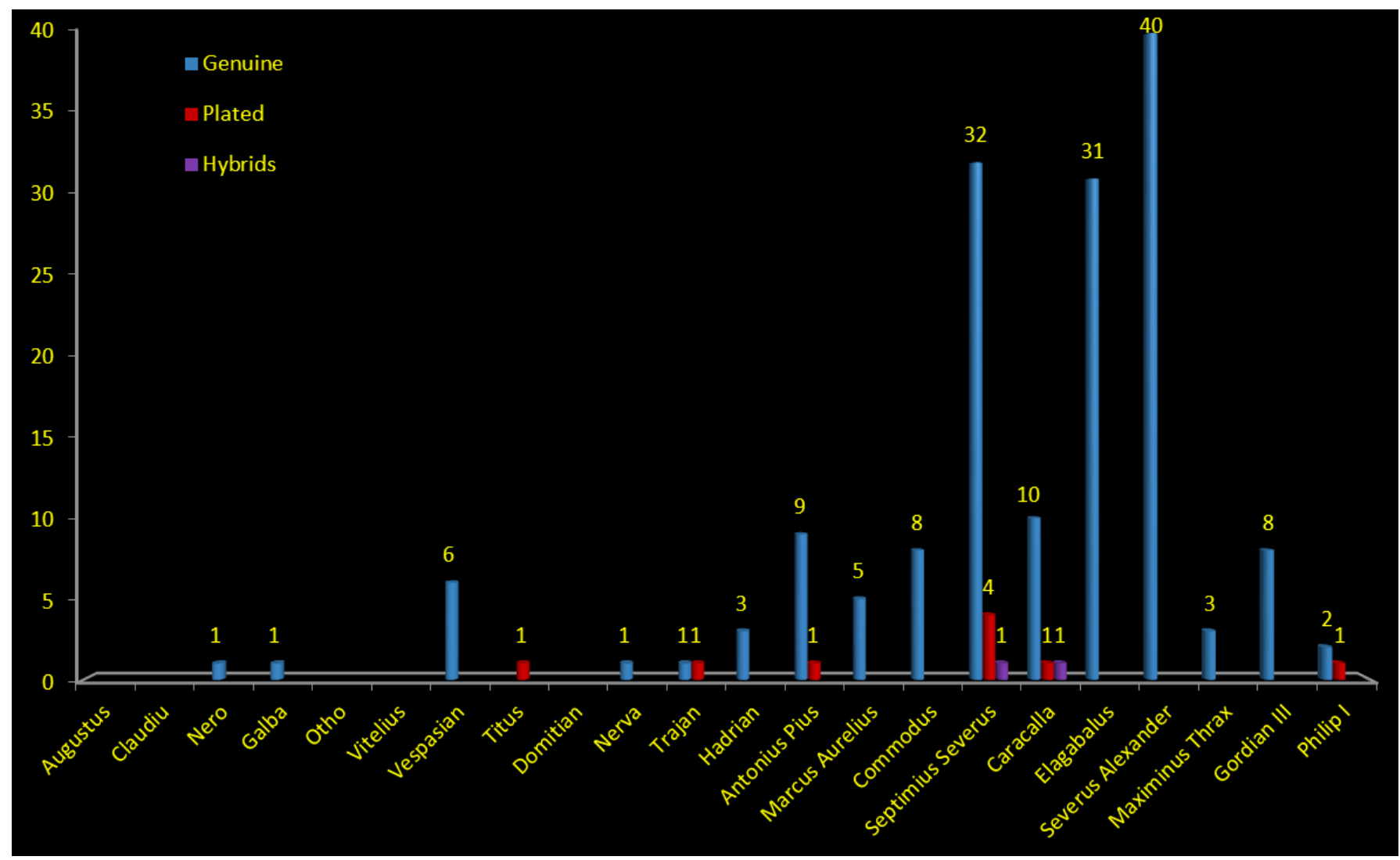

Fig.14. Graph of silver coins from Eining - number of pieces for each issuer;

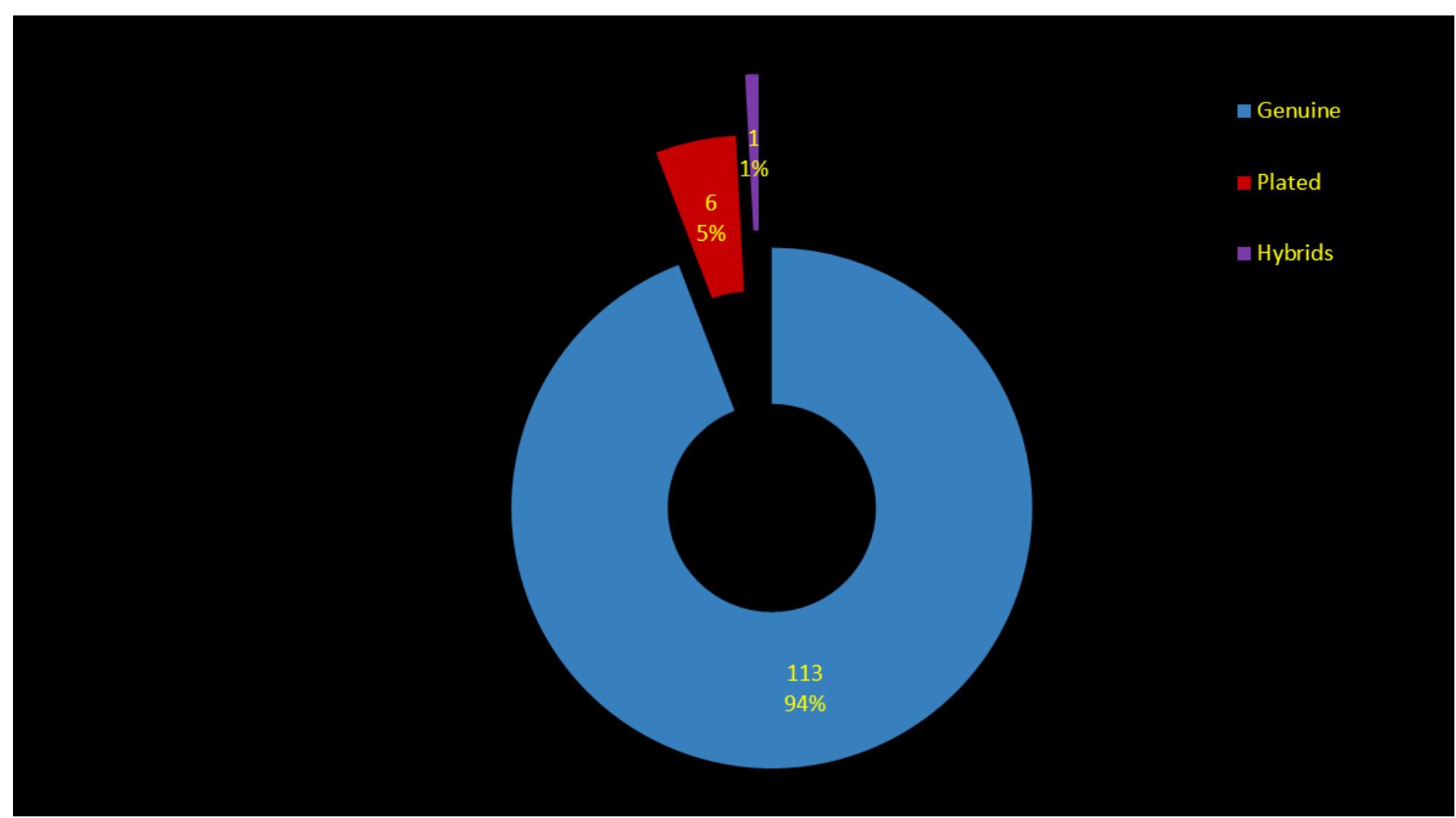

Fig.15. Graph of silver coins from Augusta Vindelicorum - number of coins and their proportion on the site;

in the first half of I century AD., later being destroyed during the civil war of $69 \mathrm{AD}^{35}$. The vicus formed around the castrum managed to continue its existence even after this event ${ }^{36}$.

35 VICI.ORG/vici/9743.

36 WÖRISHOFER/SIGG/SEITZ 2005, 127-133.
On this archaeological site, there have been found 59 silver coins ${ }^{37}$ all of them genuine as seen in Fig. 17. Most of them have been dated for Trajan (98-117), Antoninus Pius (138-161) and Septimius Severus (193-211).

${ }_{37}$ FMRD 1962, 114. 


\section{Studies}

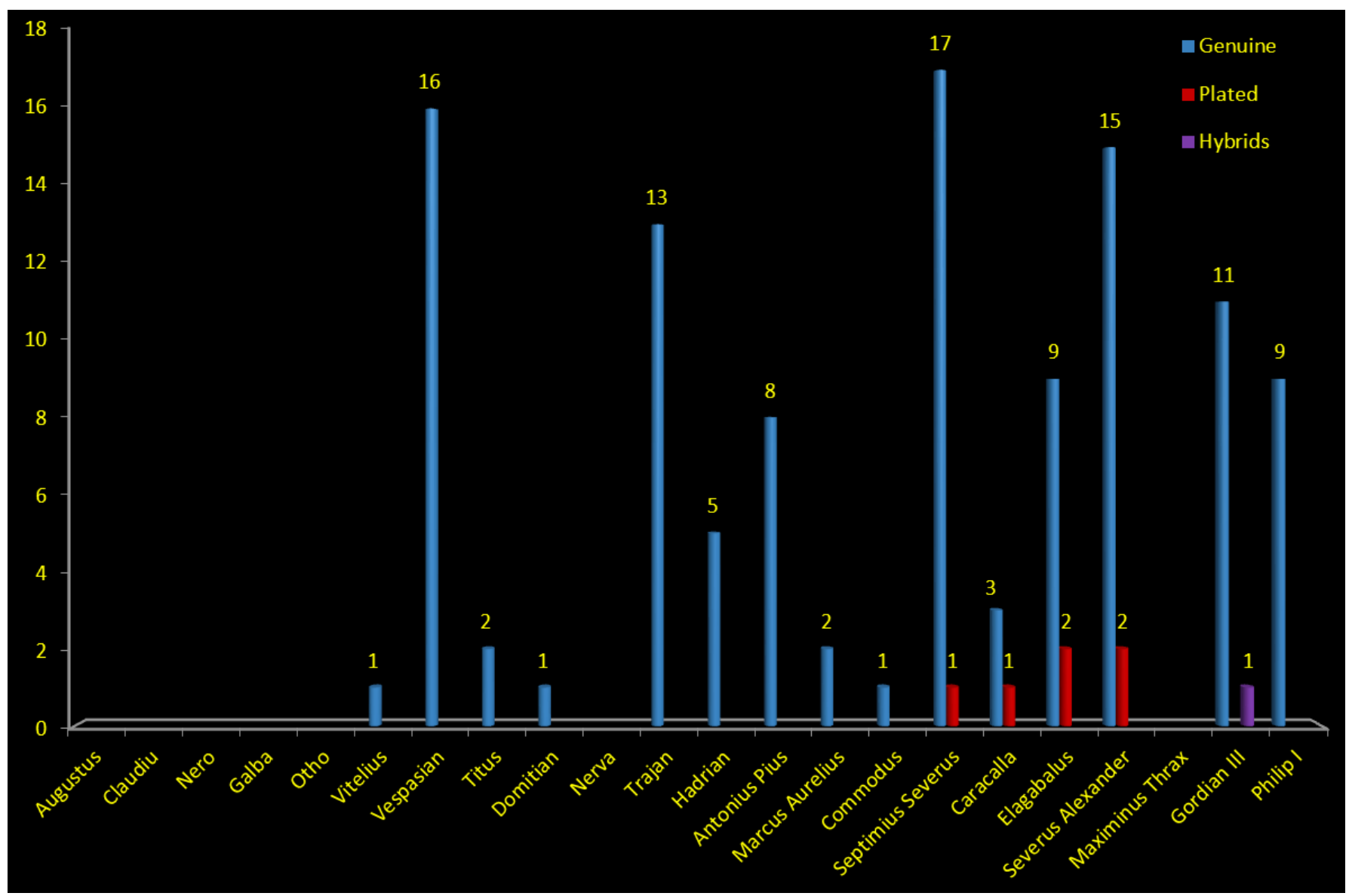

Fig.16. Graph of silver coins from Augusta Vindelicorum - number of pieces for each issuer;

When the Roman frontier moved on the Neckar : the territory of modern town Rottenburg am Neckar river during the reign of Trajan (98-117) around $98 \mathrm{AD}:$ (Germany) also got under Roman authority, the town of

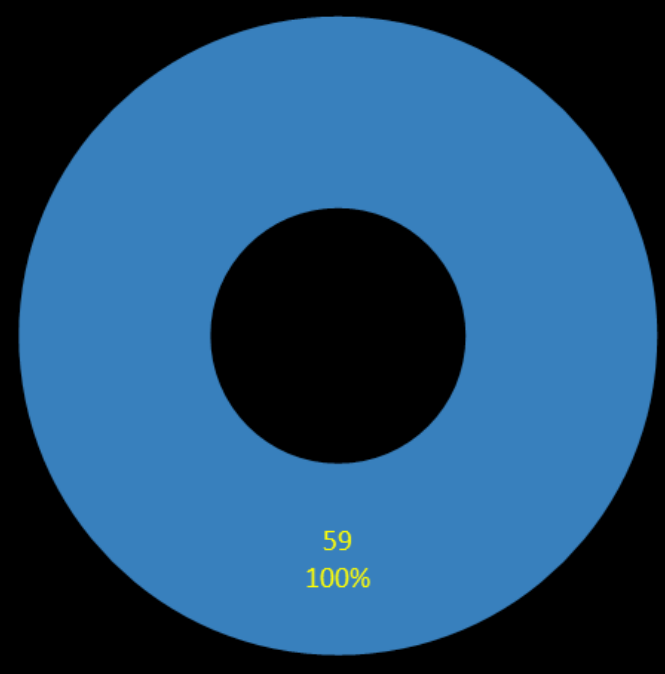

Fig.17. Graph of silver coins from Aislingen - number of coins and their proportion on the site; 


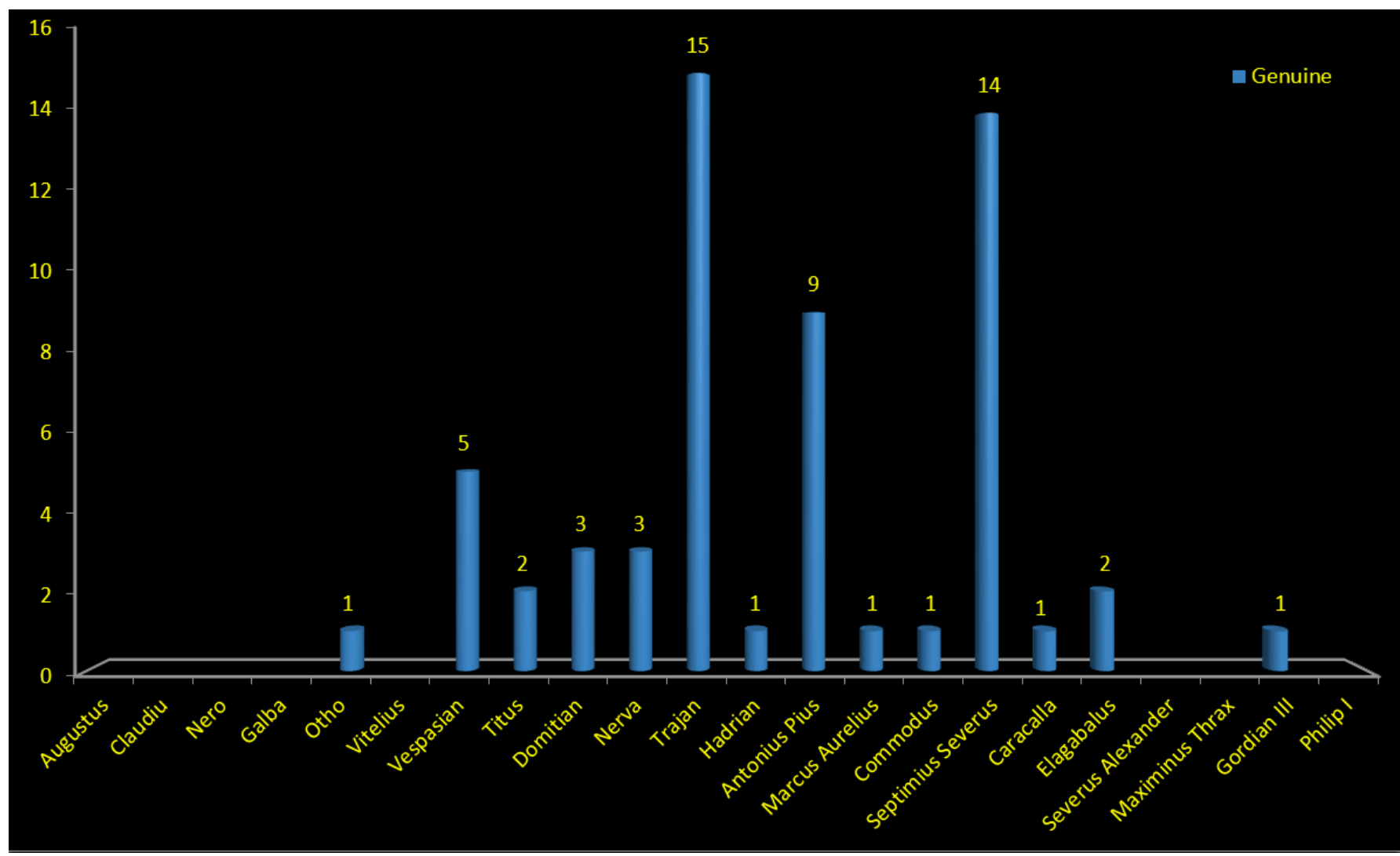

Fig.18. Graph of silver coins from Aislingen - number of pieces for each issuer;

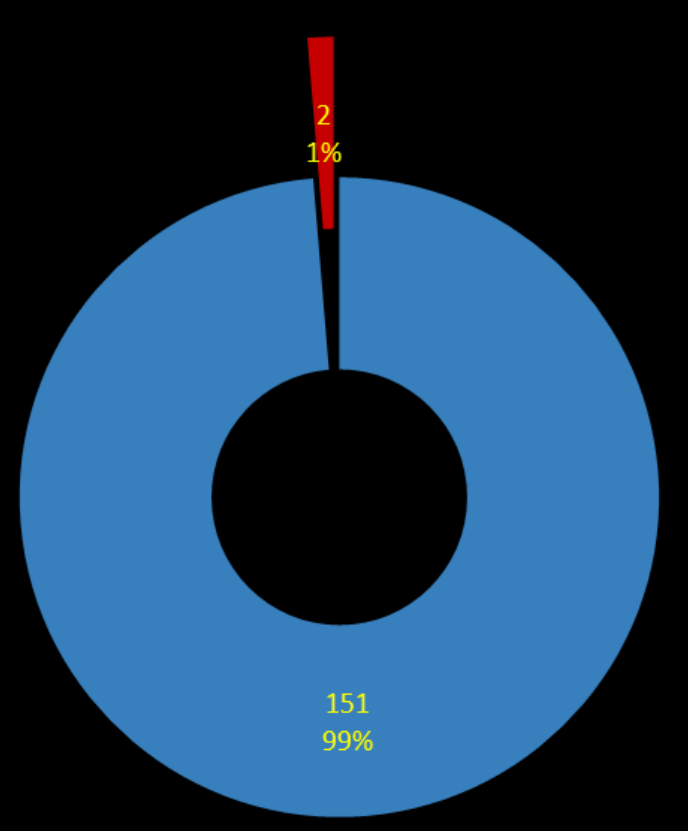

口 Genuine

口 Plated

Fig.19. Graph of silver coins from Sumelocenna - number of coins and their proportion on the site;

Sumelocenna being settled here.

On this location, there have been identified 153 silver coins $^{38}$ as seen in Fig. 19, 151 on them representing 99\% are genuine while two pieces which make up $1 \%$ are plated. 38 FMRD 1964/3, 225.
When distributing these pieces according to the issuer as seen in Fig. 20 we can observe how the majority of coins are dated during Vespasian (69-79), the Antoninian period, the Severian Dynasty or beginning of Military Anarchy period. : Highest values are reached during Septimius Severus (193- 


\section{Studies}

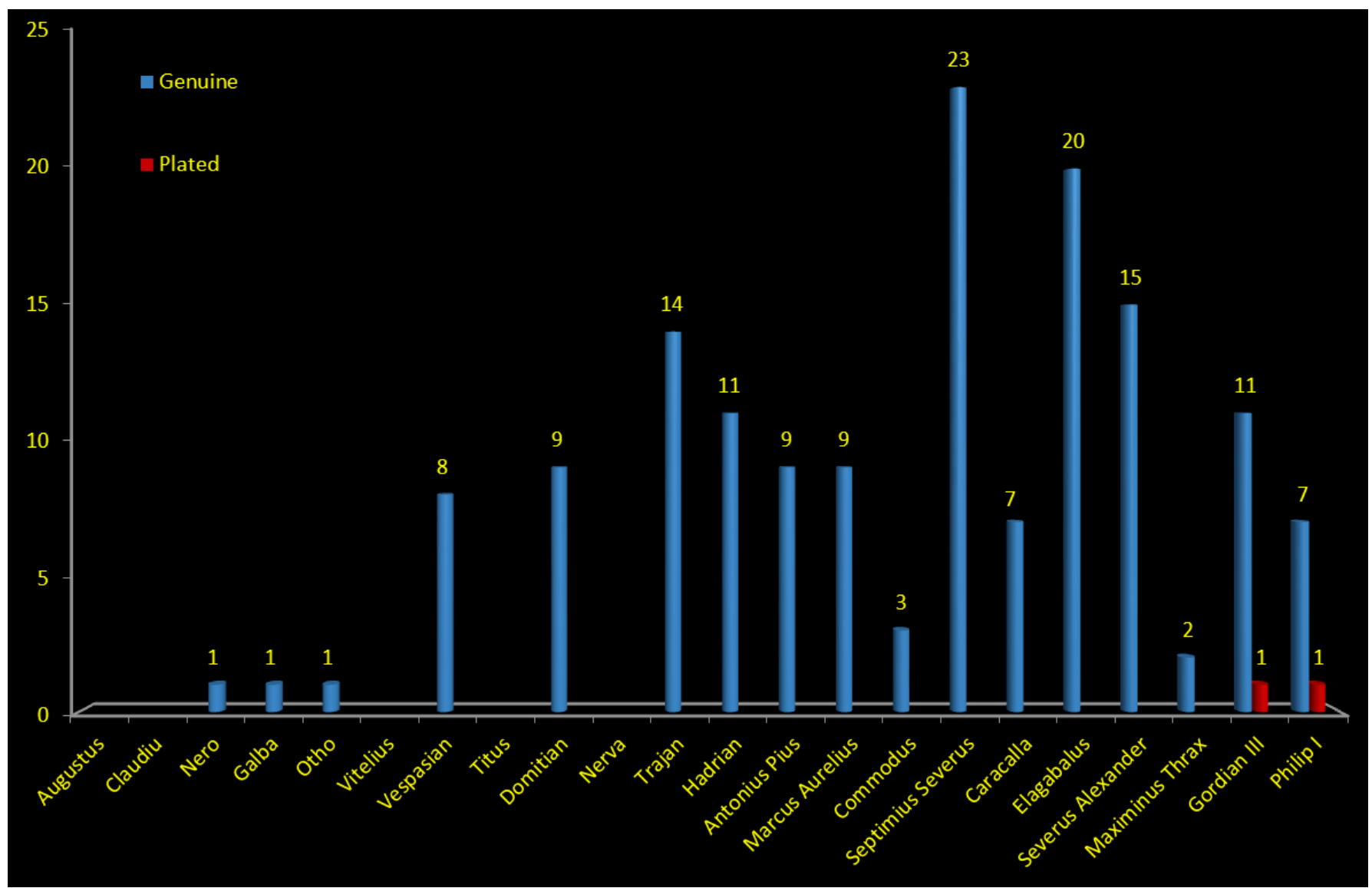

Fig.20. Graph of silver coins from Sumelocenna - number of pieces for each issuer;

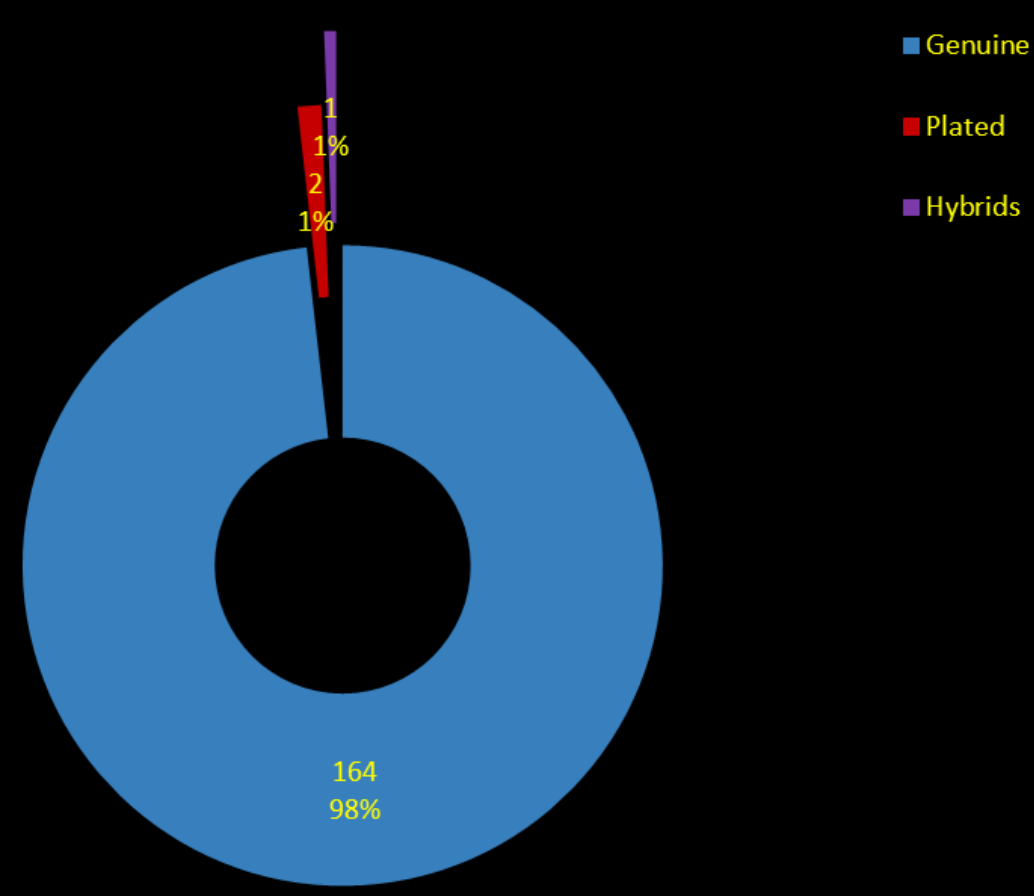

Fig.21. Graph of silver coins from Bad Cannstatt - number of coins and their proportion on the site;

211) and Elagabalus (218-222).

Close to modern town of Stuttgart, on the shore of the Neckar river, there use to be a Roman cavalry fort situated at Bad Cannstatt (Germany) around 85-90 $\mathrm{AD}^{39}$. Close to this camp which was garrisoned by Ala I Scubulorum ${ }^{40}$ 39 VICI.ORG/vici/9681.

40 DENKMALPFLEGE-SEITEN.DE. FMRD 1964, 259. 


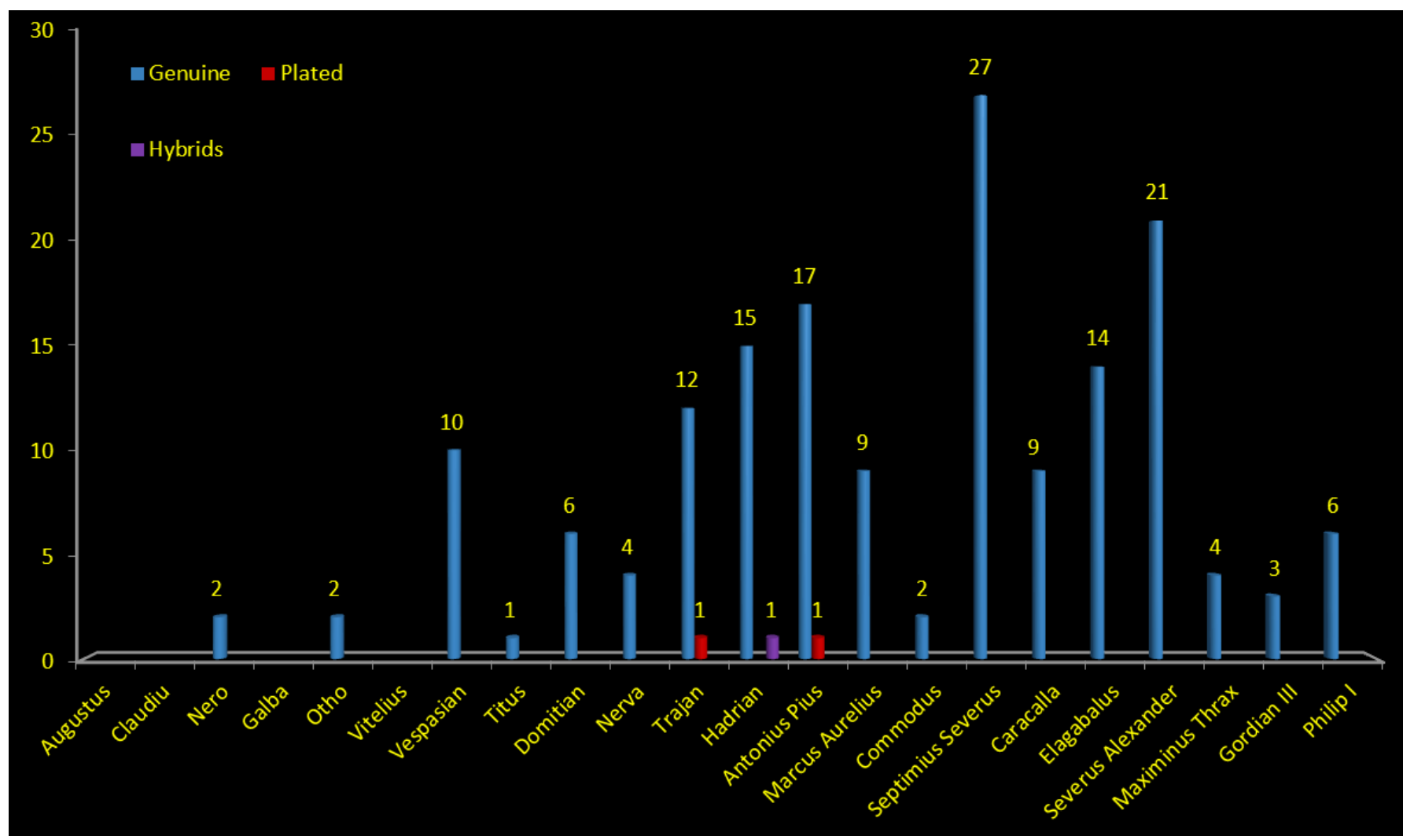

Fig.22. Graph of silver coins from Bad Cannstatt - number of pieces for each issuer;

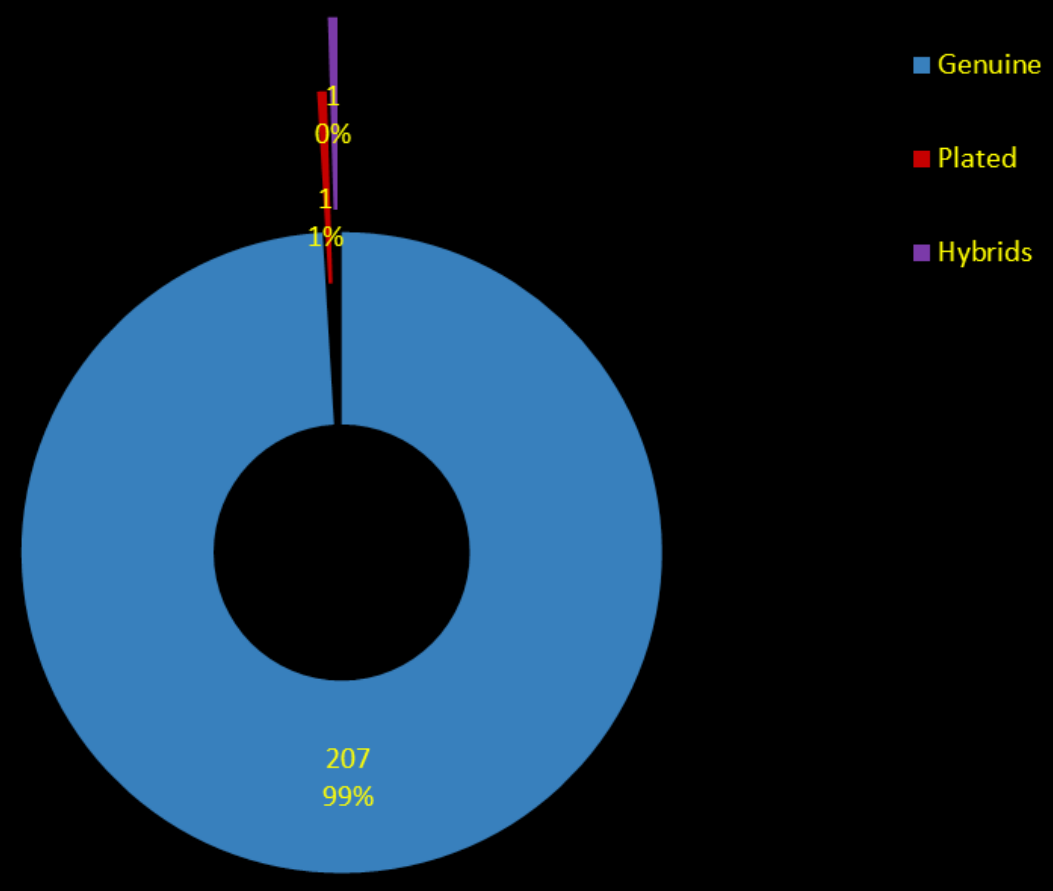

Fig.23. Graph of silver coins from Rheinzabern - number of coins and their proportion on the site;

a civilian settlement appeared ${ }^{41}$ that continued to survive even after the Roman troops were moved on the new expanded frontier around $150 \mathrm{AD}^{42}$.

Thus, in Fig. 21 it's possible to see the 167 silver coins

41 VICI.ORG/vici/14198.

42 DENKMALPFLEGE-SEITEN.DE. discovered at Bad Cannstatt ${ }^{43}, 164$ with a proportion of $98 \%$ are genuine, two coins representing $1 \%$ are plated and one piece representing $1 \%$ is hybrid.

Also, in Fig. 22 the distribution of these pieces is showed, the majority of genuine pieces are showing images 43 FMRD 1964/4, 262. 


\section{Studies}

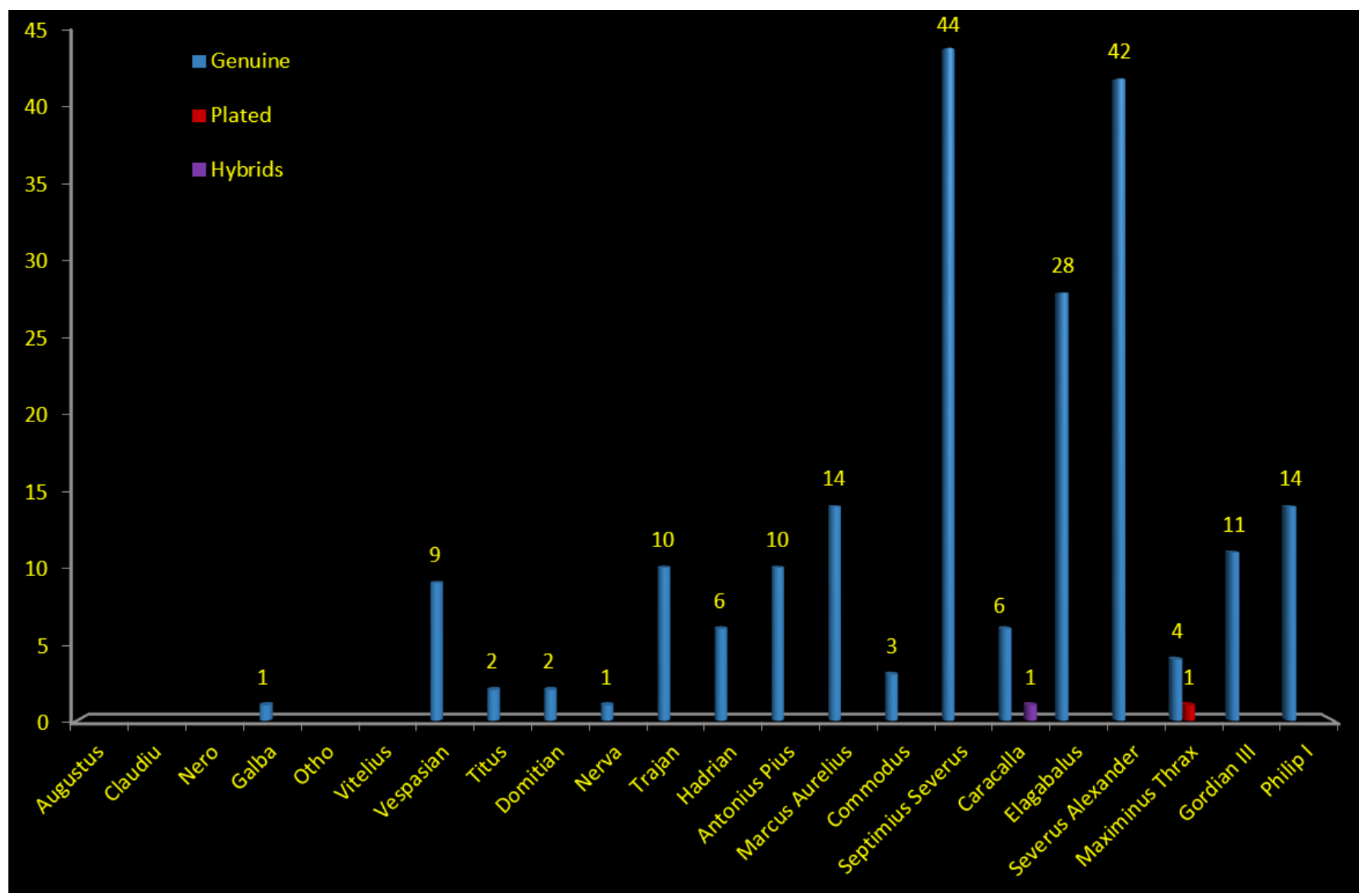

Fig.24. Graph of silver coins from Rheinzabern - number of pieces for each issuer;

dated during the reign of Vespasian (69-79), Antoninian and Severian period, especially under Septimius Severus (193211) and Severus Alexander (222-235).

Tabernae was the Latin name of the Roman settlement situated under the modern town of Rheinzabern (Germany) $)^{44}$, an economic center for pottering manufacturing, especially Terra Sigillata from I century AD until late antiquity ${ }^{45}$.

Looking at Fig. 23 we find that there have been discovered 209 silver coins at Rheinzabern ${ }^{46}$, from witch 207 representing $99 \%$ are genuine, one piece is plated and one is a hybrid, both representing under $1 \%$.

Meanwhile, Fig. 24 shows how the distribution of these coins spreads from Vespasian (69-79) until the beginning of the Military Anarchy at 235 AD. As seen in many other cases, most of the coins are dated for the period Severian period, especially during the reign of Septimius Severus (193-211), Elagabalus (218-222) and Severus Alexander (222-235).

Around the year $10 \mathrm{BC}$ on the territory of modern Speyer (Germany), a Roman castrum was constructed which became the foundation for the future town of Noviomagus ${ }^{47}$.

During Domitian's reign (81-96) the soldiers are transferred on the new frontier and the settlement will be administrated by civilians. During the III century, by the

\footnotetext{
44 VICI.ORG/vici/2785.

45 PLEIADES.STOA.ORG.

46 FMRD 1965, 91.

47 VICI.ORG/vici/2784.
}

same time with the Alamanni attacks and the abandonment of the extended Limes Germanicus, Speyer will become again a frontier town which will fall to invading barbarians around $275 \mathrm{AD}^{48}$.

For the site of Speyer/Noviomagus there have been identified 56 silver coins ${ }^{49}$, showed in Fig. 25, from witch 55 pieces representing $98 \%$ are genuine and one coin representing $2 \%$ is plated.

In Fig. 26 we can see how most of the coins are dated at the Severian Dynasty and beginning of Military Anarchy.

The Roman settlement at Heidelberg (Germany) was formed by a military fort constructed around $70 \mathrm{AD}$ and the surrounding canabae which appeared around the fort ${ }^{50}$. The castrum was originally made of wood ${ }^{51}$ but it was later destroyed in a fire and rebuild in stone around $90 \mathrm{AD}^{52}$.

Ever since 80/90 AD there used to be a wooden bridge over the Neckar river which was replaced by a stone based bridge around $200 \mathrm{AD}^{53}$.

Graphs made for Heidelberg show the 30 silver pieces $^{54}$ discovered, all of them being genuine coins as seen in Fig. 27. We can also see the distribution of these pieces in Fig. 28 and how they were dated for the Flavian, Antoninian and Severian period.

Around the year $155 \mathrm{AD}$ a Roman fort was constructed
48 CÜPPERS 2005
49 FMRD 1965, 503.
50 LUDWIG 1997, 37.
51 VICI.ORG/vici/10492
${ }_{52}$ LUDWIG 1997, 37.
53 LUDWIG 1997, 44
${ }^{54}$ FMRD 1980, 75. 


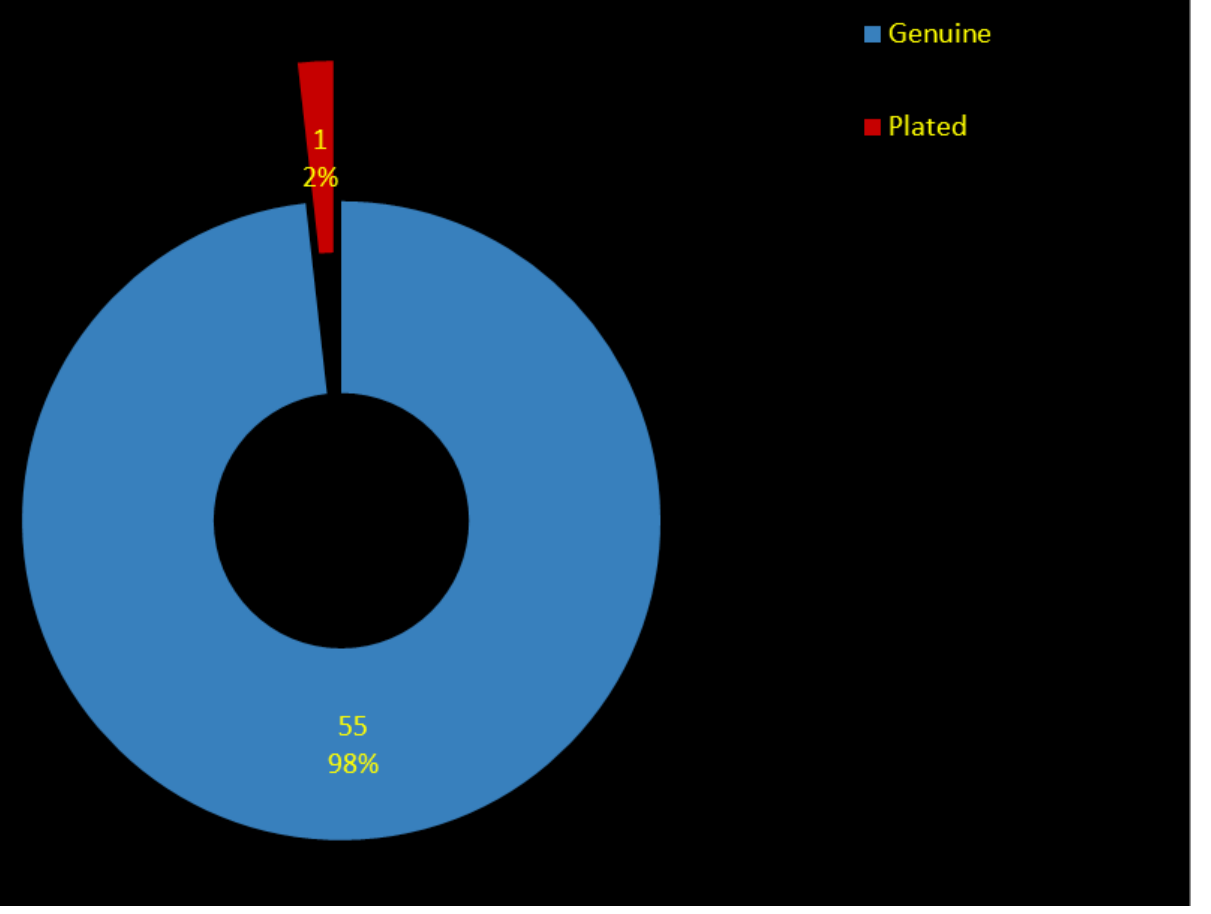

Fig.25. Graph of silver coins from Speyer - number of coins and their proportion on the site;

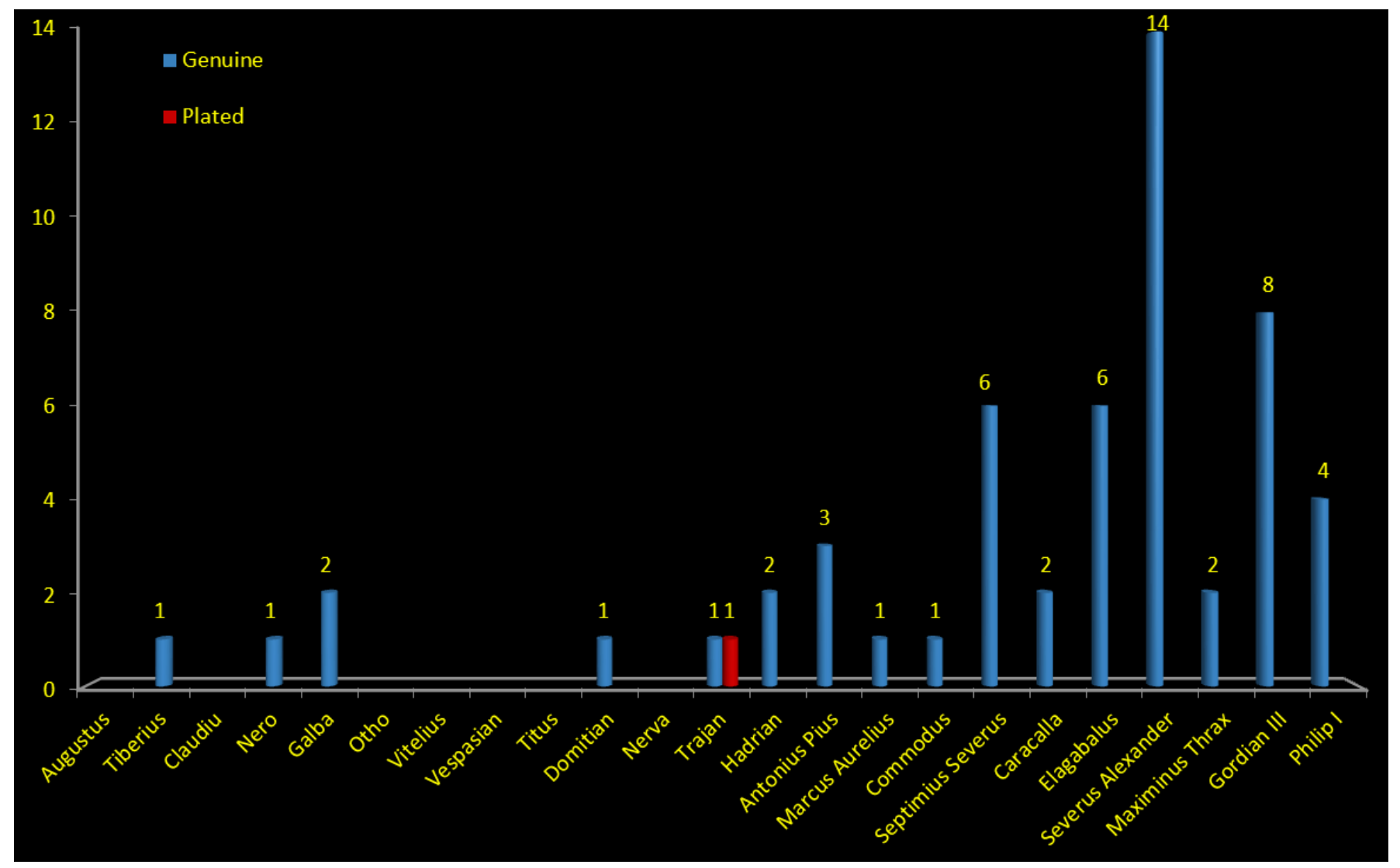

Fig.26. Graph of silver coins from Speyer - number of pieces for each issuer;

close to modern Miltenberg (Germany), a cavalry camp with the purpose of keeping a watch on where the limes meet the Main river ${ }^{55}$.

This camp, initially raised using wood and earth

55 Vici.Org/vici/9805. by Cohors I Sequanorum et Rauracorum equitata and later reinforced using stone ${ }^{56}$.

There have been discovered 75 silver pieces ${ }^{57}$, all of them identified as genuine as see in Fig. 29, most of them ${ }^{56}$ FMRD 1975, 120.

57 FMRD 1975, 121. 


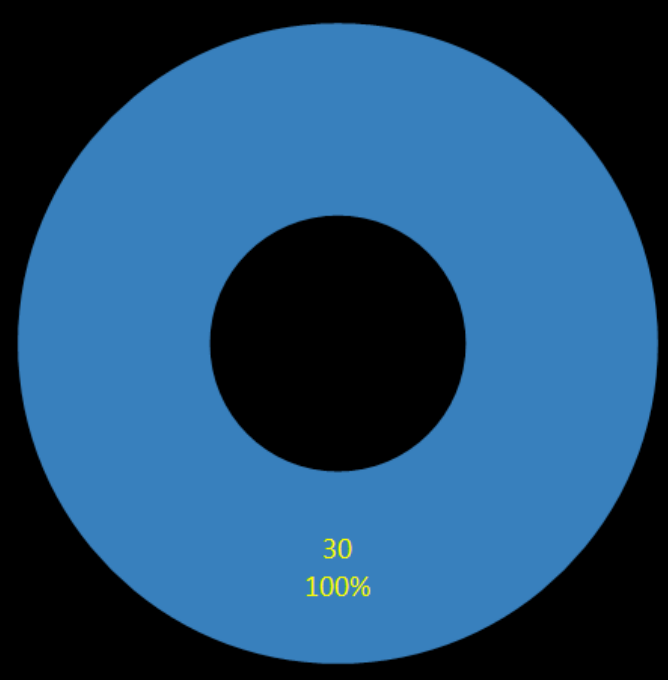

Fig.27. Graph of silver coins from Heidelberg - number of coins and their proportion on the site;

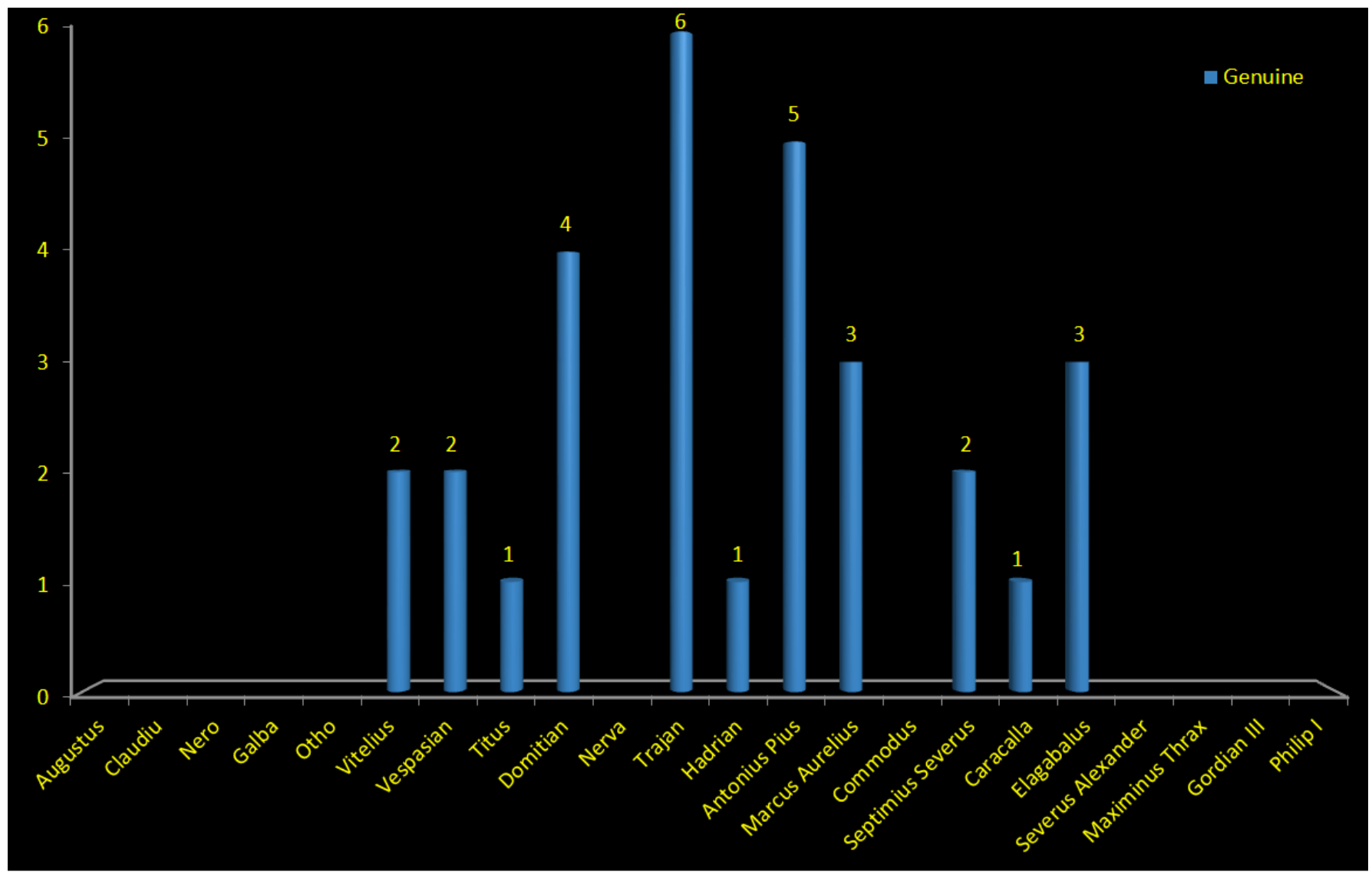

Fig.28. Graph of silver coins from Heidelberg - number of pieces for each issuer;

were dated for Septimius Severus (193-211) as seen in Fig. 30.

Close to Stockstadt am Main (Germany) were identified two Roman forts, one of them made using earth and wood ${ }^{58}$ while the second using stone ${ }^{59}$. With the help of archaeological discoveries, the arriving of the garrison was dated between 90-100 $\mathrm{AD}^{60}$.

58 VICI.ORG/vici/10369.

59 VICI.ORG/vici/4407.

60 BAATZ 1969, 71. KORTÜM 1998, 5-65. SCHÖNBERGER 1985, 465. 


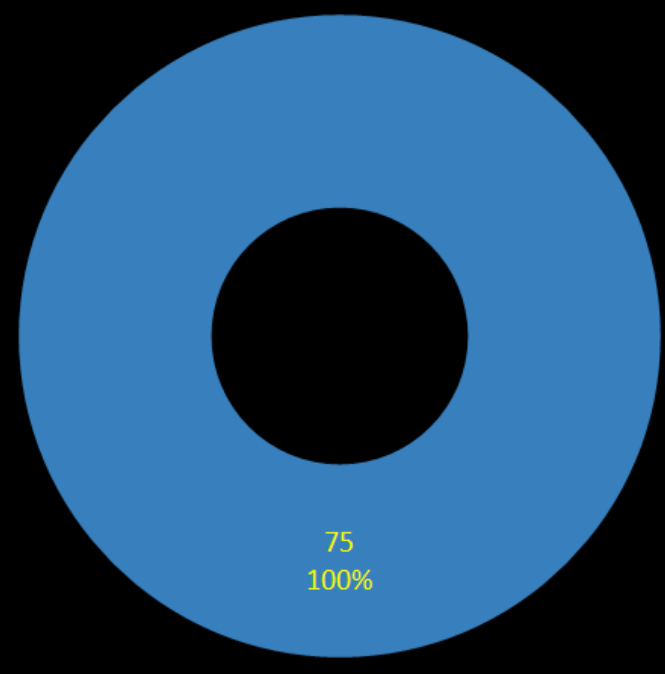

Fig.29. Graph of silver coins from Miltenberg - number of coins and their proportion on the site;

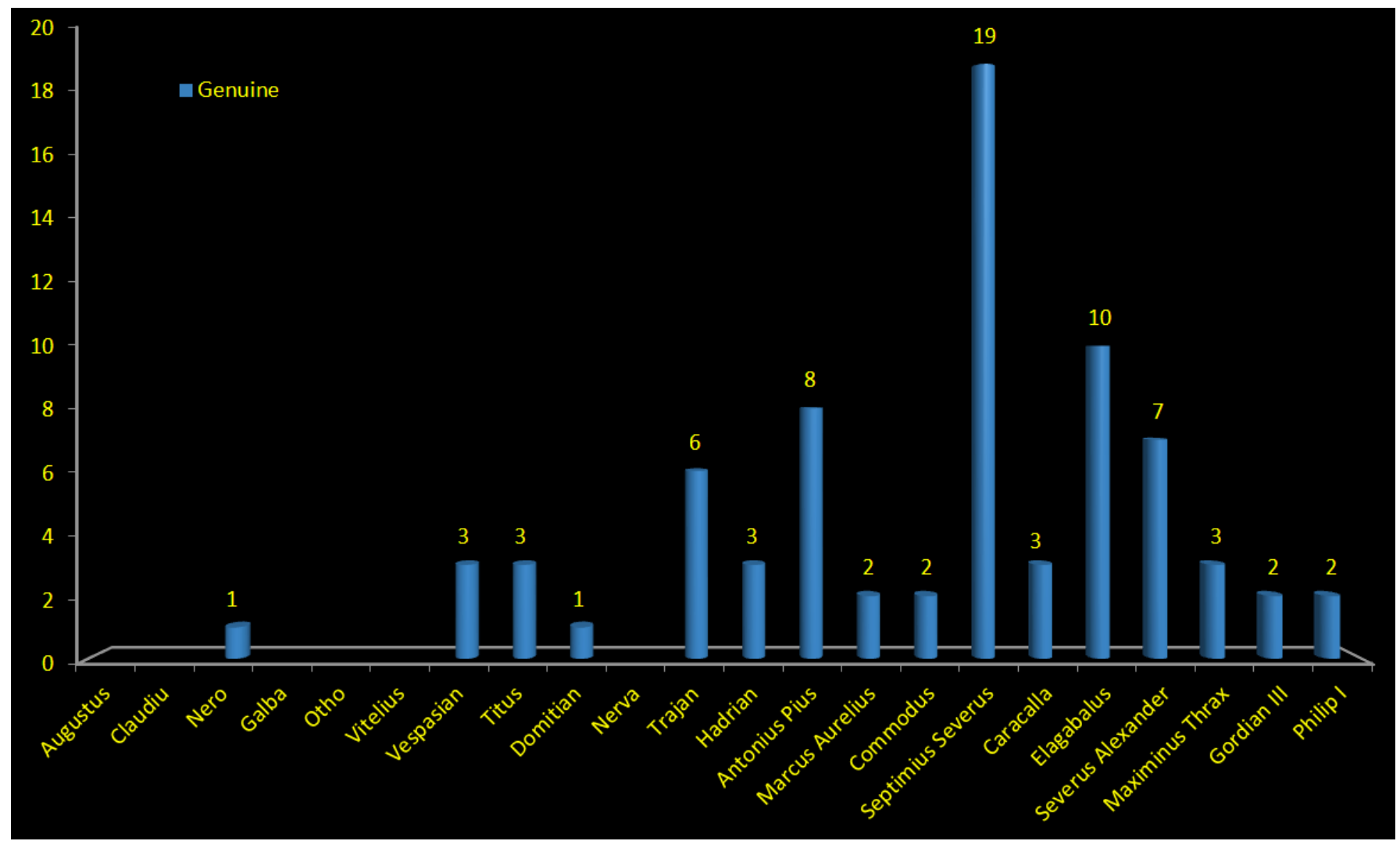

Fig.30. Graph of silver coins from Miltenberg - number of pieces for each issuer;

This fort served as garrison for cohors III Aquitanorum equitata civium Romanorum ${ }^{61}$ until it was relocated at the beginning of the II century ${ }^{62}$. In her place was brought cohors II Hispanorum equitata Pia Fidelis which only remained until

\footnotetext{
61 SCHÖNBERGER 1985, 465

62 FMRD 1975, 25
}

the middle of the II century ${ }^{63}$ being replaced by cohors I Aquitanorum veterana equitata ${ }^{64}$.

Therefore, on the site from Stockstadt am Main there were discovered 144 silver pieces ${ }^{65}$ all of them being genuine

${ }_{63}$ CASTRITIUS/CLAUSS/HEFNER 1977, 237-308. SCHÖNBERGER 1985, 465.

${ }^{64}$ CIL XIII/11780. CIL XIII/11782. SCHÖNBERGER 1985, 465.

65 FMRD 1975, 28 


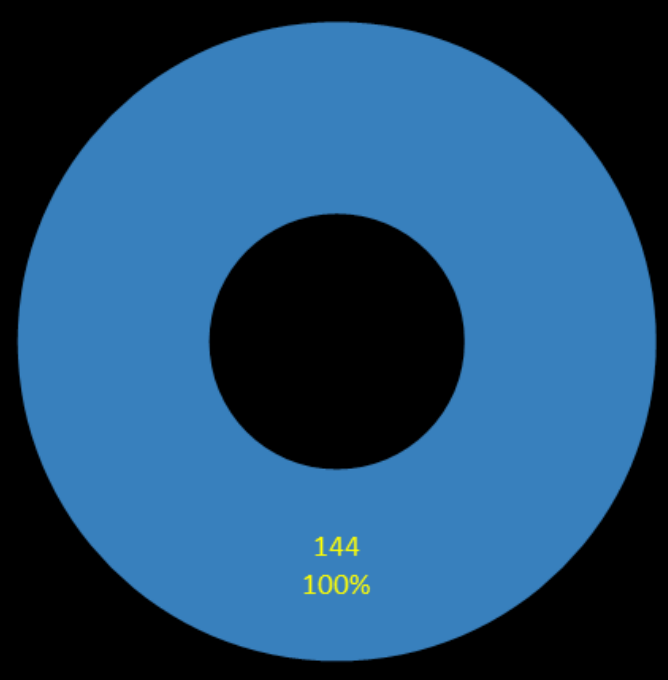

Fig.31. Graph of silver coins from Stockstadt am Main - number of coins and their proportion on the site;

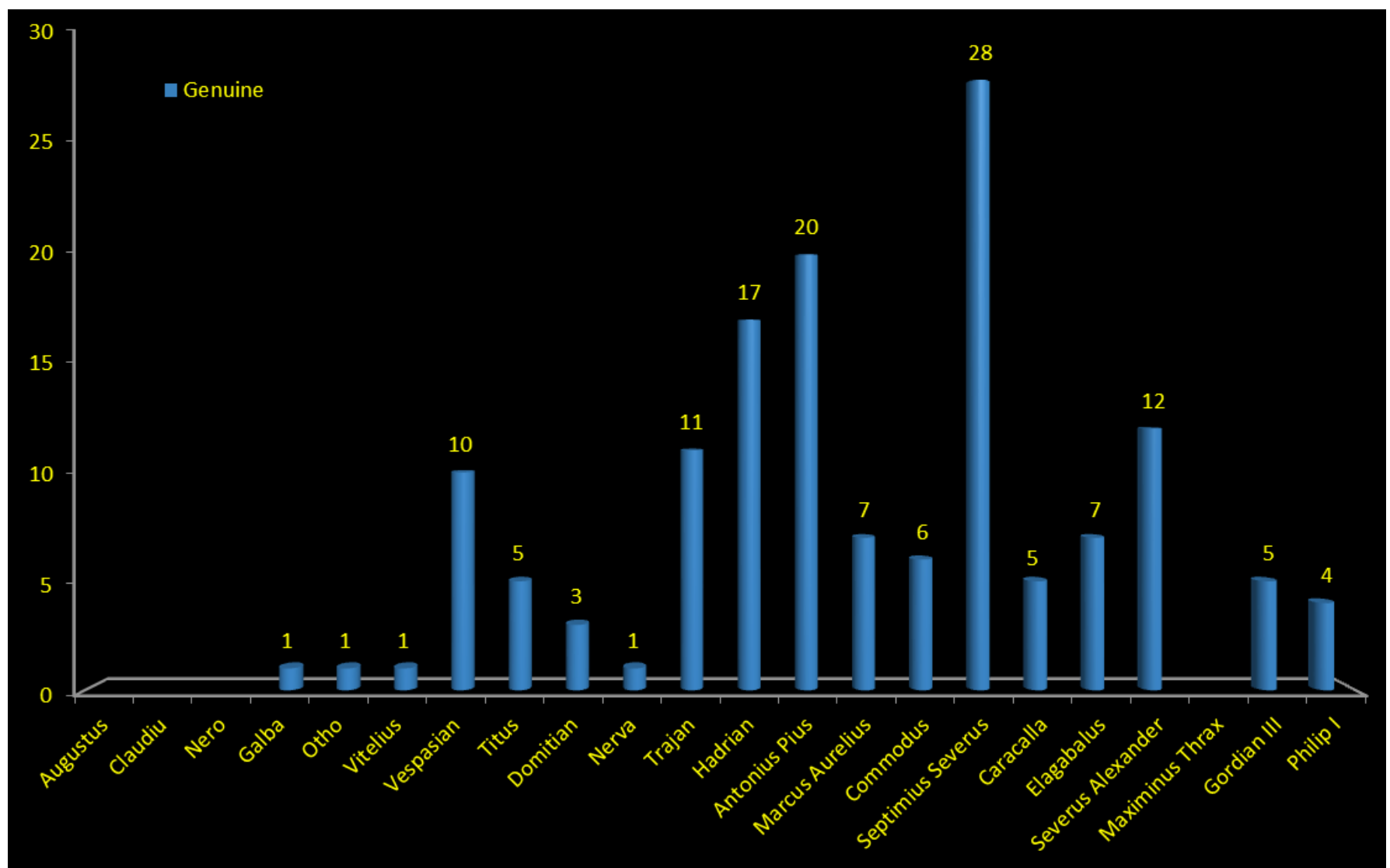

Fig.32. Graph of silver coins from Stockstadt am Main - number of pieces for each issuer;

as seen in Fig. 31. After distributing the coins according to their issuer and his time of reign we get the graph from Fig. 32, from which we can observe how many of the coins are dated during the reign of Hadrian (117-138), Antonius Pius (138-161) and Septimius Severus (193-211).

Nida was a settlement located north-west from modern city of Frankfurt am Main ${ }^{66}$ (Germany), first Roman finds in the area date back during the reign of Vespasian (69-79) ${ }^{67}$.

The area received some kind of "special" attention

${ }_{66}$ VICI.ORG/vici/10379.

${ }_{67}$ FORUM/NIDA. 


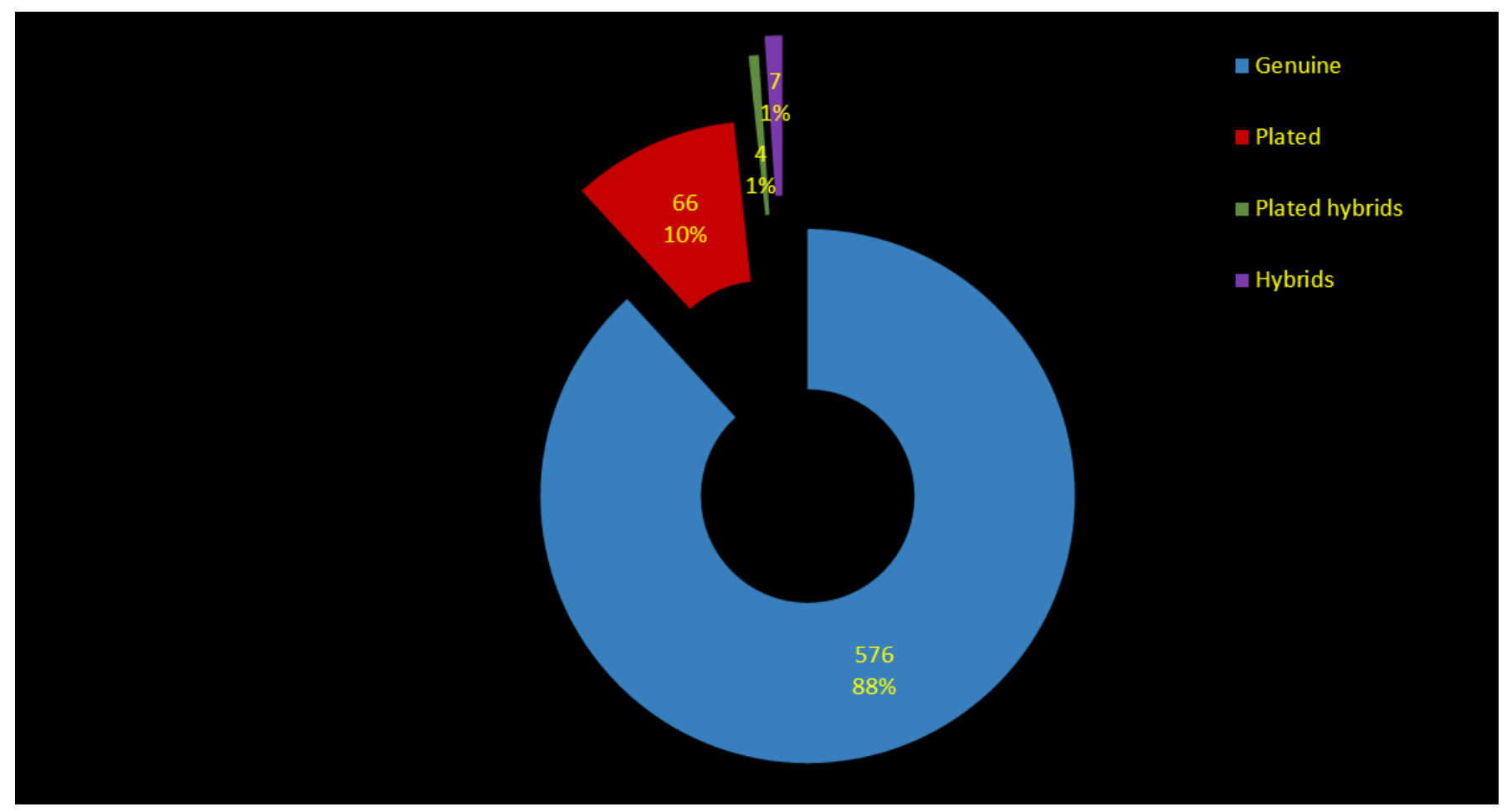

Fig.33. Graph of silver coins from Nida - number of coins and their proportion on the site;

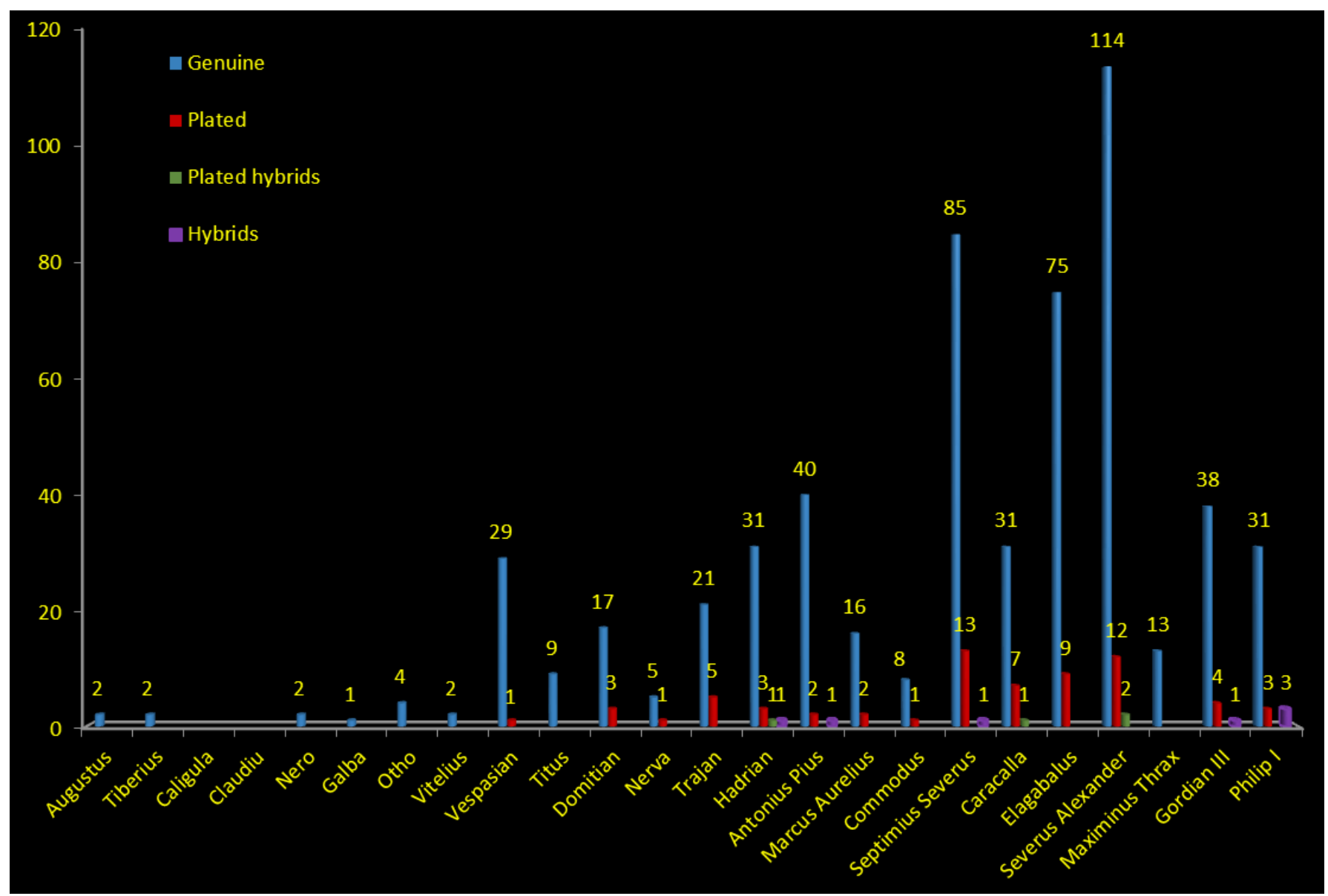

Fig.34. Graph of silver coins from Nida - number of pieces for each issuer;

from the Roman High Command since archaeological there have been identified ten military encampments which were active around $75 \mathrm{AD}^{68}$, among the recognized troops were 68 FASOLD 1998, 14.
Ala I Flavia Gemina ${ }^{69}$, Cohors XXXII Voluntariorum Civium

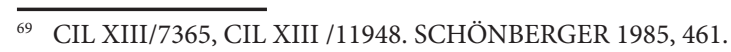




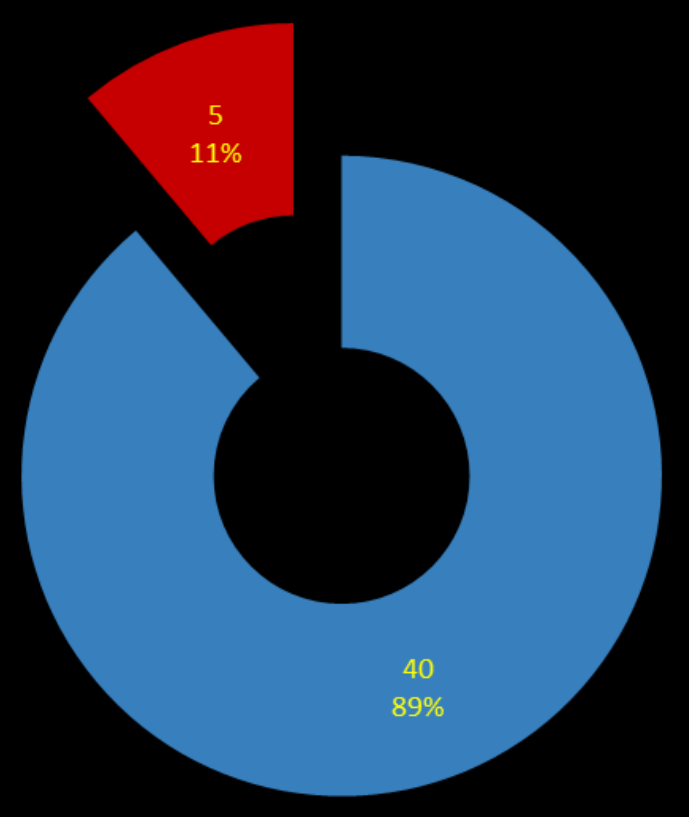

口 Genuine

- Plated

Fig.35. Graph of silver coins from Rückingen - number of coins and their proportion on the site;

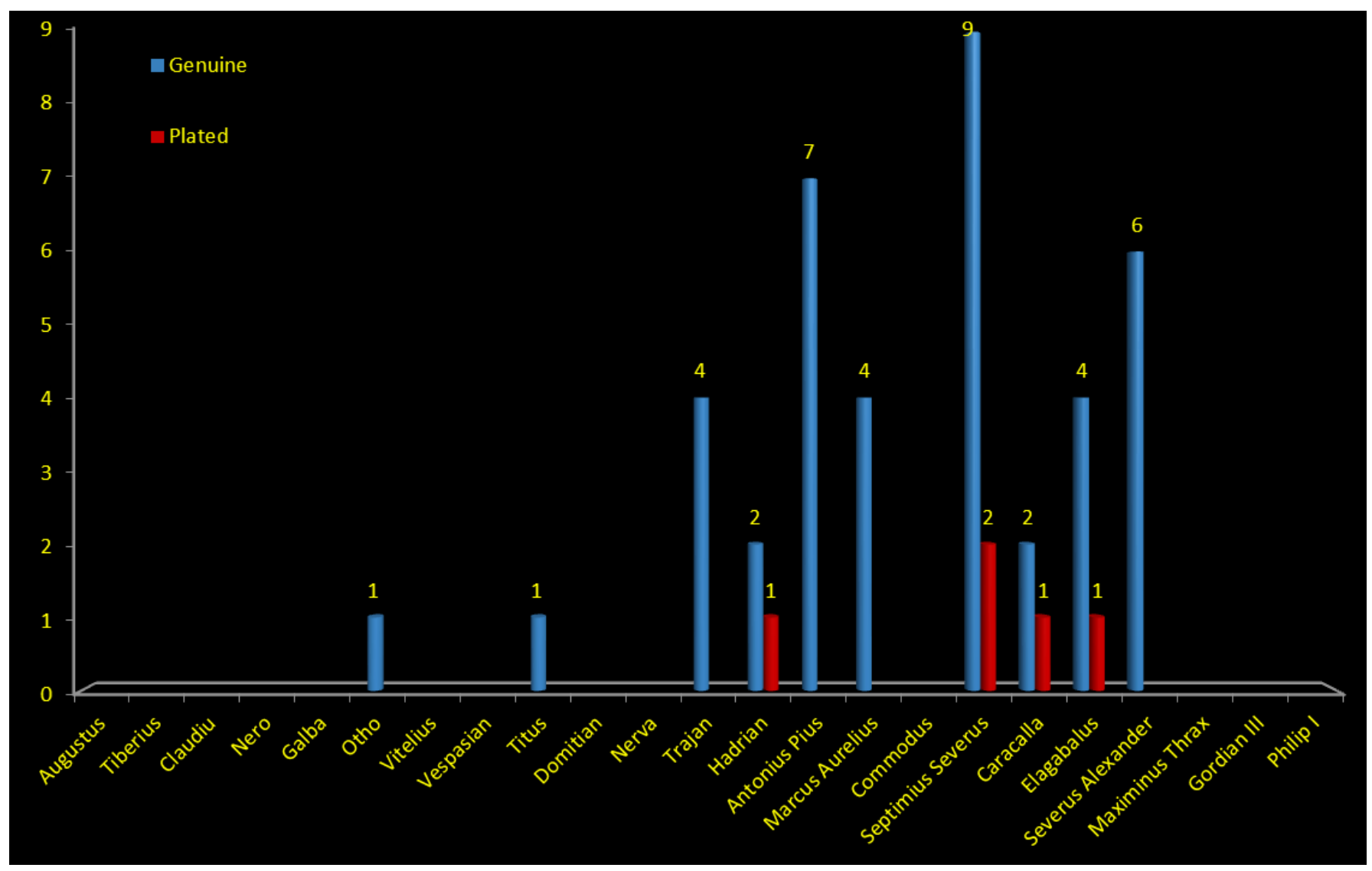

Fig.36. Graph of silver coins from Rückingen - number of pieces for each issuer;

Romanorum ${ }^{70}$ and Cohors IIII Vindelicorum ${ }^{71}$.

During the reign of Trajan (98-117) the soldiers were moved on new defensive positions ${ }^{72}$ and the civil settlement ${ }_{70}$ CIL XIII /7362, CIL XIII /7381, CIL XIII /7382, CIL XIII /7383. SCHÖNBERGER 1985, 461.

${ }^{71}$ CIL XIII /7331, CIL XIII /11947, AE 1978/542.

72 FORUM/NIDA. will expand in the former military quarters where new monumental buildings were raised ${ }^{73}$.

Thus, in the area of Nida there were discovered 653 silver coins $^{74}, 576$ representing $88 \%$ are genuine, 66

73 HULD-ZETSCHE 1994, 18-19.

${ }_{74}$ FMRD 1989b. 


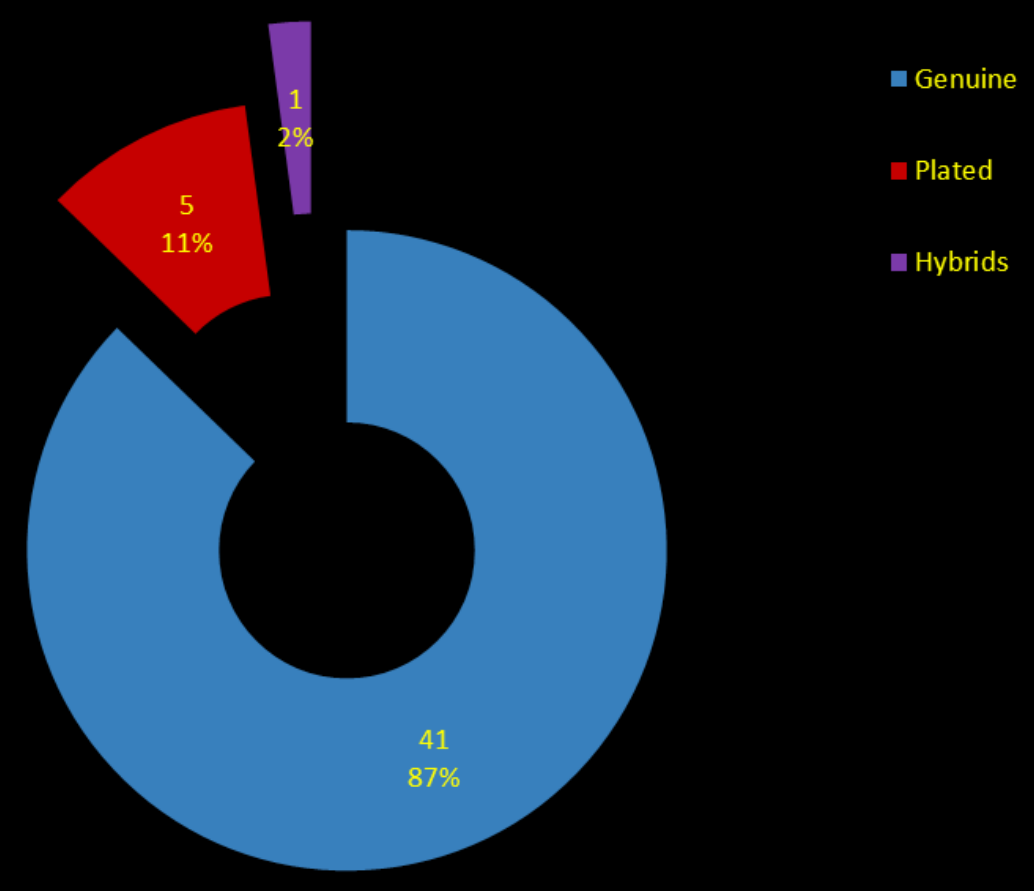

Fig.37. Graph of silver coins from Friedberg - number of coins and their proportion on the site;

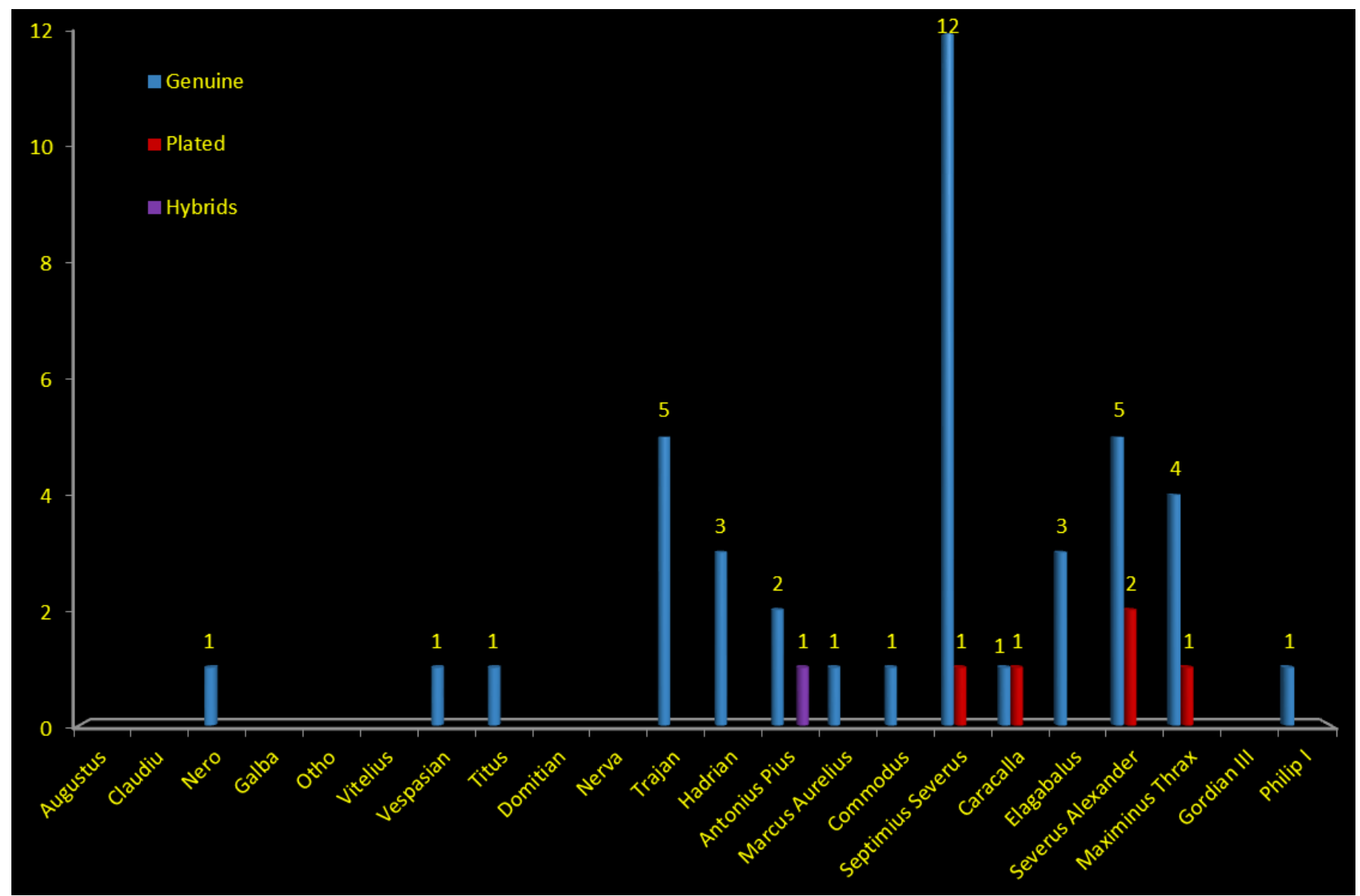

Fig.38. Graph of silver coins from Friedberg - number of pieces for each issuer;

representing $10 \%$ are plated, four coins representing $1 \%$ are plated hybrids and another seven pieces representing $1 \%$ are hybrids, as seen in Fig. 33.
Regarding the distribution of coins for this location Fig. 34 was created, we can see that there were discovered coins with the image of issuers from the beginning of the I 


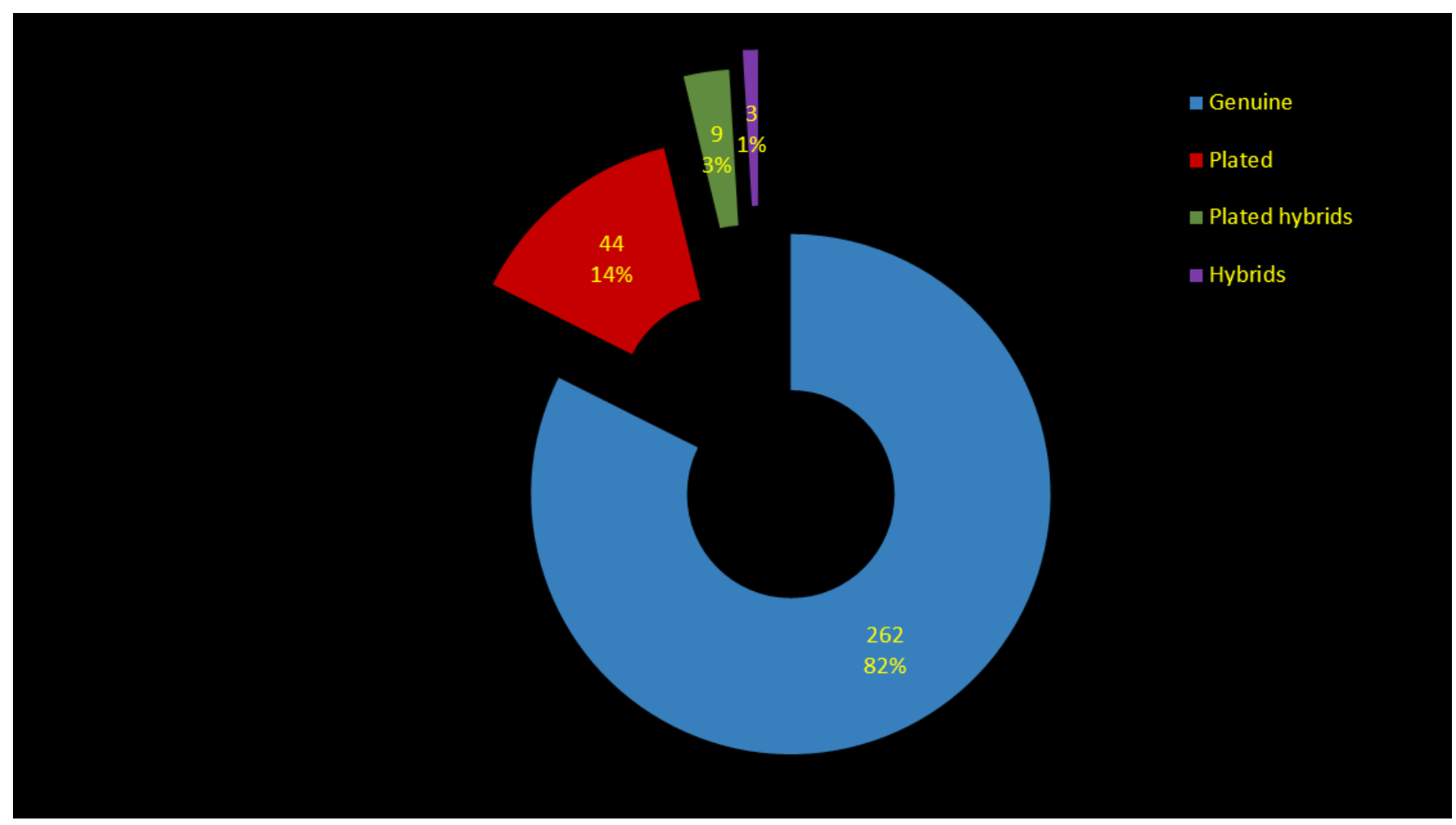

Fig.39. Graph of silver coins from Mogontiacum - number of coins and their proportion on the site;

century. By the time of Vespasian (69-79) the coin index goes visible up, the highest values being recorded for the Severian Dynasty when the coin index doubles in quantity for issuers like Septimius Severus (193-211), Elagabalus (218-222) and Severus Alexander (222-235).

Roman castrum of Rückingen (Germany) was situated at $300 \mathrm{~m}$ from the limes ${ }^{75}$, constructed between 110-125 AD during the reign of Trajan (98-117) and Hadrian $(117-138)^{76}$ and served as garrison for Cohors III Dalmatarum pia fidels which was brought here in the same period ${ }^{77}$.

For this location, there have been discovered 45 silver coins $^{78}$ as seen in Fig. 35, from which 40 pieces which form $89 \%$ are genuine and five coins are plated with a representation of $11 \%$. Fig. 36 shows the distribution of these pieces, not very helpful because of the small number of coins for this site.

At Friedberg (Germany) used to be a Roman fort dated at the I century AD, more exactly during the military expeditions carried out by Germanicus ${ }^{79}$. The fort was abandoned and during the reign of Vespasian (69-79) a new camp was built in this area which was used until the frontier was moved further east and the troops along with it.

There have been identified 47 silver pieces ${ }^{80}$ as seen in Fig. 37. From these coins 41 were identified as genuine representing $87 \%$, five were plated representing $11 \%$ and one piece is a hybrid representing $2 \%$.

Also, in Fig. 38 we can see how these coins were distributed according to the issuer represented on them,

\footnotetext{
FMRD 1994a, 99.

76 REUTER 2004, 97-106.

77 FMRD 1994a, 100.

78 FMRD 1994a.

79 VICI.ORG/vici/4414.

80 FMRD 1989a.
}

many of them being dated for during Septimius Severus (193-211).

The origin of Mogontiacum (Mainz, Germany) is close related with the first legionary camp erected by Drusus in 13-12 BC on a strategic hill near the shore of the river Rhine ${ }^{81}$. This first camp could garrison two Roman legions, first arrived here were most likely Legio I Germanica și $V$ Alaudae $^{82}$.

The garrison from Mainz was transferred, other troops will pass through here like Legio XIV Gemina and XVI Gallica, Legio XIII Gemina and II Augusta ${ }^{83}$. In the end Legio XXII Primigenia will garrison the fort and maintain it until the middle of the IV century.

For Mainz/Mogontiacum, showed in Fig. 39, there have been discovered 318 silver coins ${ }^{84}, 262$ of them with a proportion of $82 \%$ are genuine, 44 with a proportion of $14 \%$ are plated, nine pieces with $3 \%$ are plated hybrids and three coins with $1 \%$ are hybrids.

Looking at Fig. 40 we can see how these pieces were distributed, very high values during the reign of Septimius Severus (193-211), Elagabalus (218-222) and Severus Alexander (222-235).

On the territory of modern Hofheim-Main-Taunus (Germany), there used to be two Roman forts but none are visible anymore at the surface of the soil ${ }^{85}$. One of them was constructed around $72 \mathrm{AD}$ using stone and was soon surrounded by a civilian vicus ${ }^{86}$.

According to Fig. 41, at Hofheim-Main-Taunus were

\footnotetext{
VICI.ORG/vici/9754. WITTEYER 1999, 1026.

82 LIVIUS.ORG/MOGONTIACUM-MAINZ.

83 LIVIUS.ORG/MOGONTIACUM-MAINZ.

84 FMRD 2006a, 33.

85 VICI.ORG/vici/8150.

86 NUBER 1983.
} 


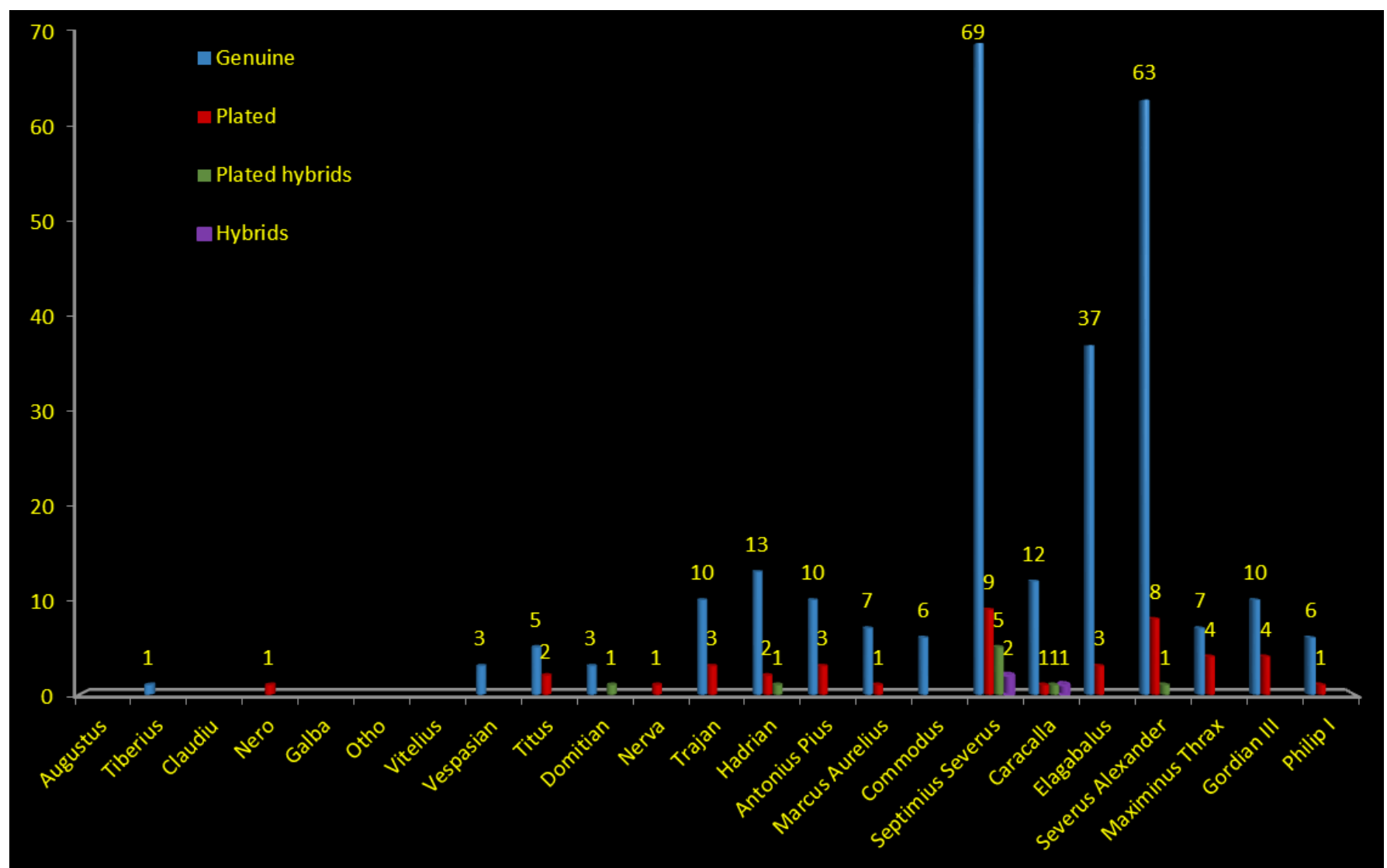

Fig.40. Graph of silver coins from Mogontiacum - number of pieces for each issuer;

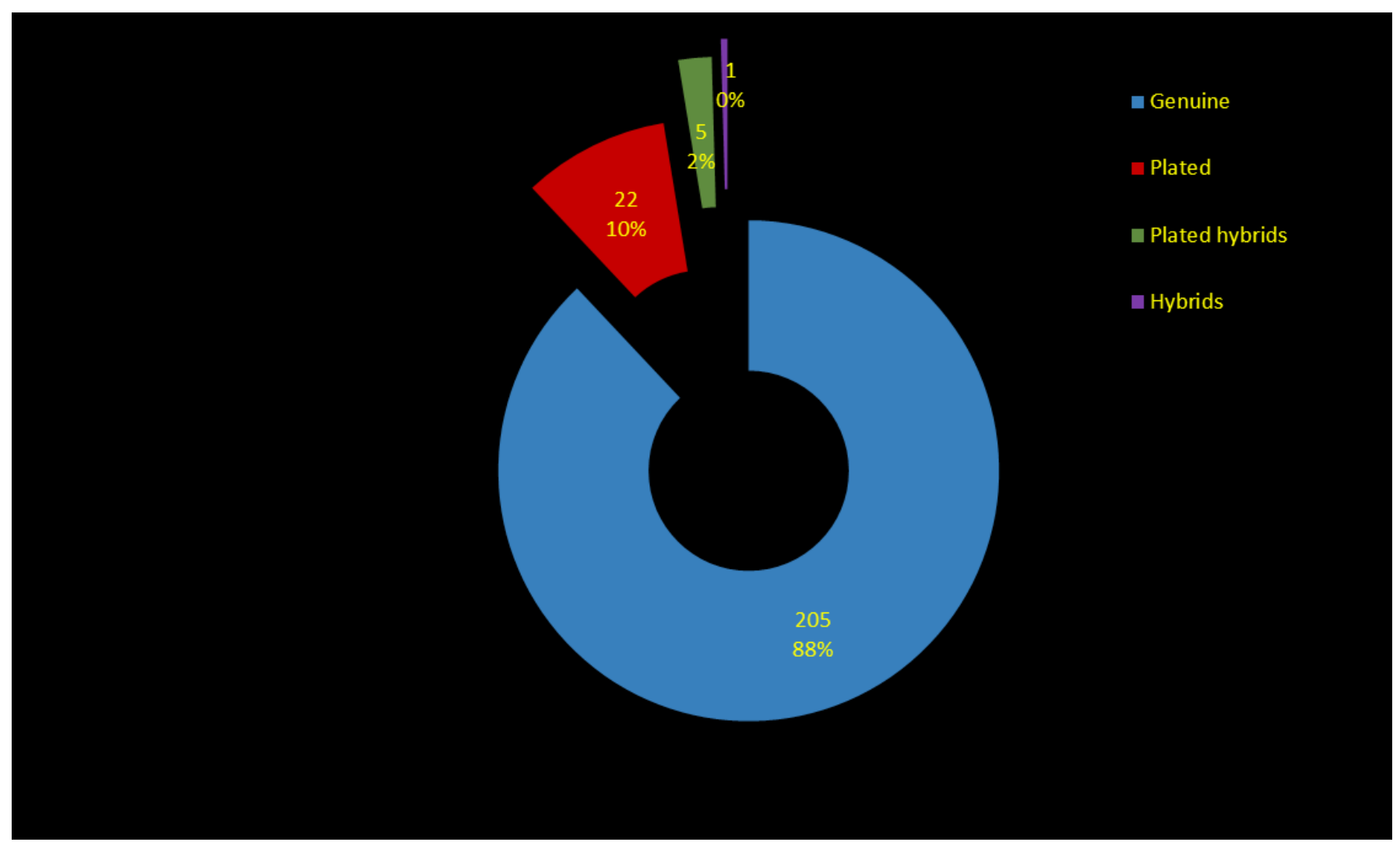

Fig.41. Graph of silver coins from Hofheim-Main-Taunus - number of coins and their proportion on the site;

discovered 233 silver coins ${ }^{87}, 205$ of these were identified

87 FMRD 1994a. as genuine representing $88 \%$ of the total number of coins, 22 pieces are plated representing $10 \%$, five coins are plated 


\section{Studies}

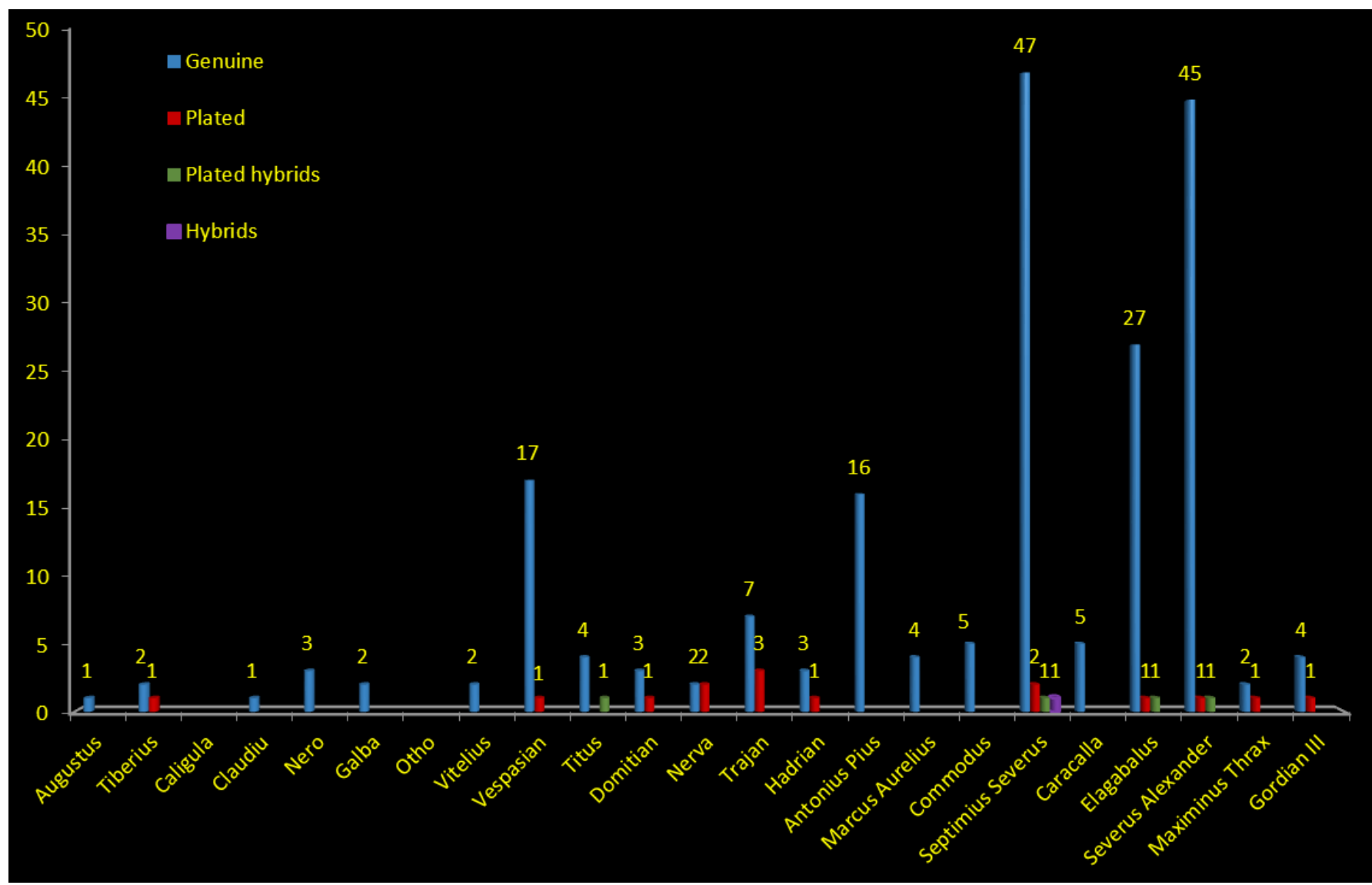

Fig.42. Graph of silver coins from Hofheim-Main-Taunus - number of pieces for each issuer;

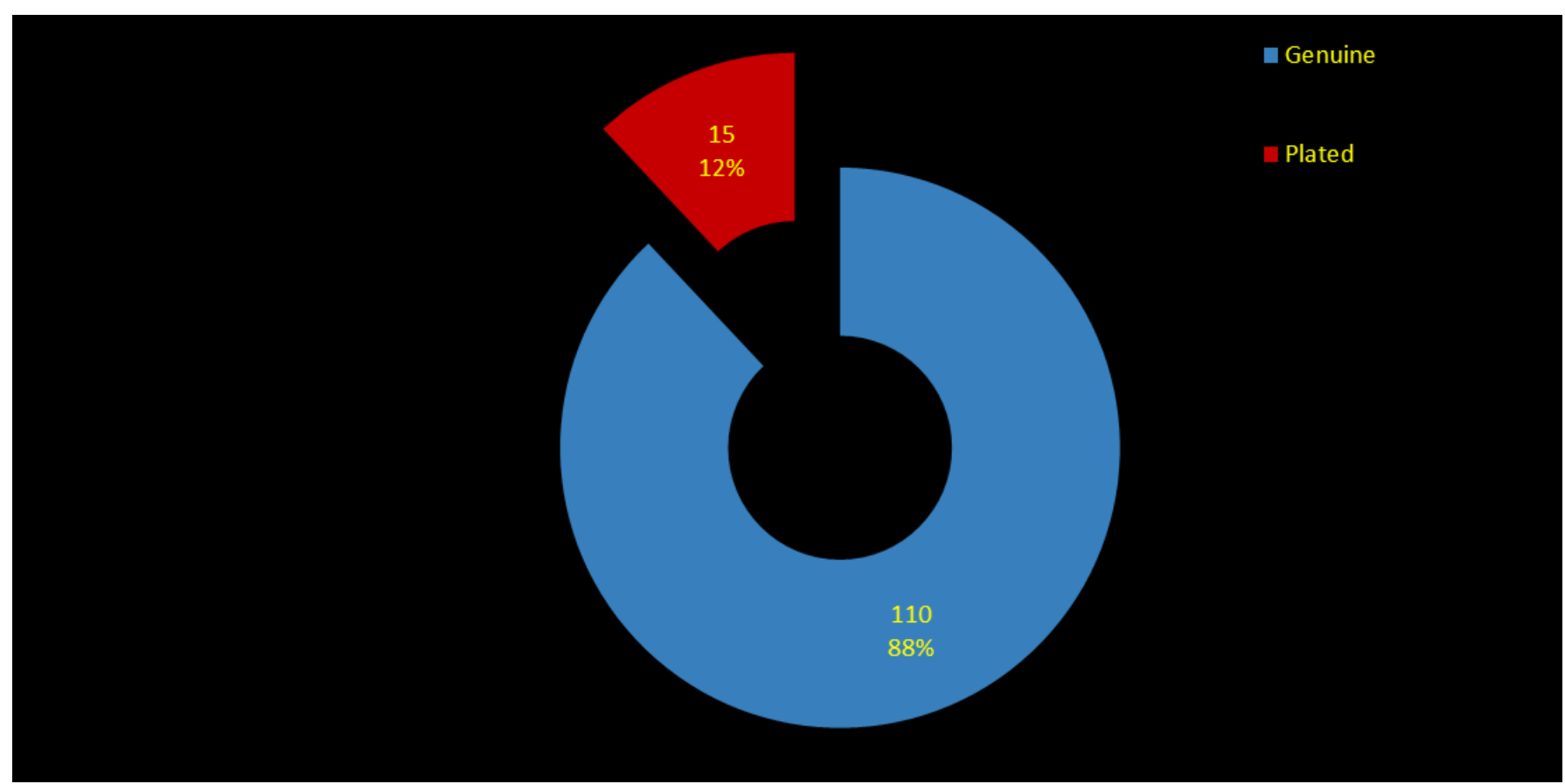

Fig.43. Graph of silver coins from Wiesbaden - number of coins and their proportion on the site;

hybrids with a proportion of $2 \%$ and one coins is a hybrid representing $1 \%$.

Looking at Fig. 42, we can observe that many coins were dated during the period of Vespasian (69-79), Antonius Pius (138-161), Septimius Severus (193-211), Elagabalus (218-222) and Alexander Severus (222-235).
Aquae Mattiacorum was the Roman name of the settlement located near modern Wiesbaden (Germany). Here was the place where a castrum was built ${ }^{88}$ and a civilian settlement was raised around it $^{89}$.

88 VICI.ORG/vici/9759.

89 VICI.ORG/vici/9758. 


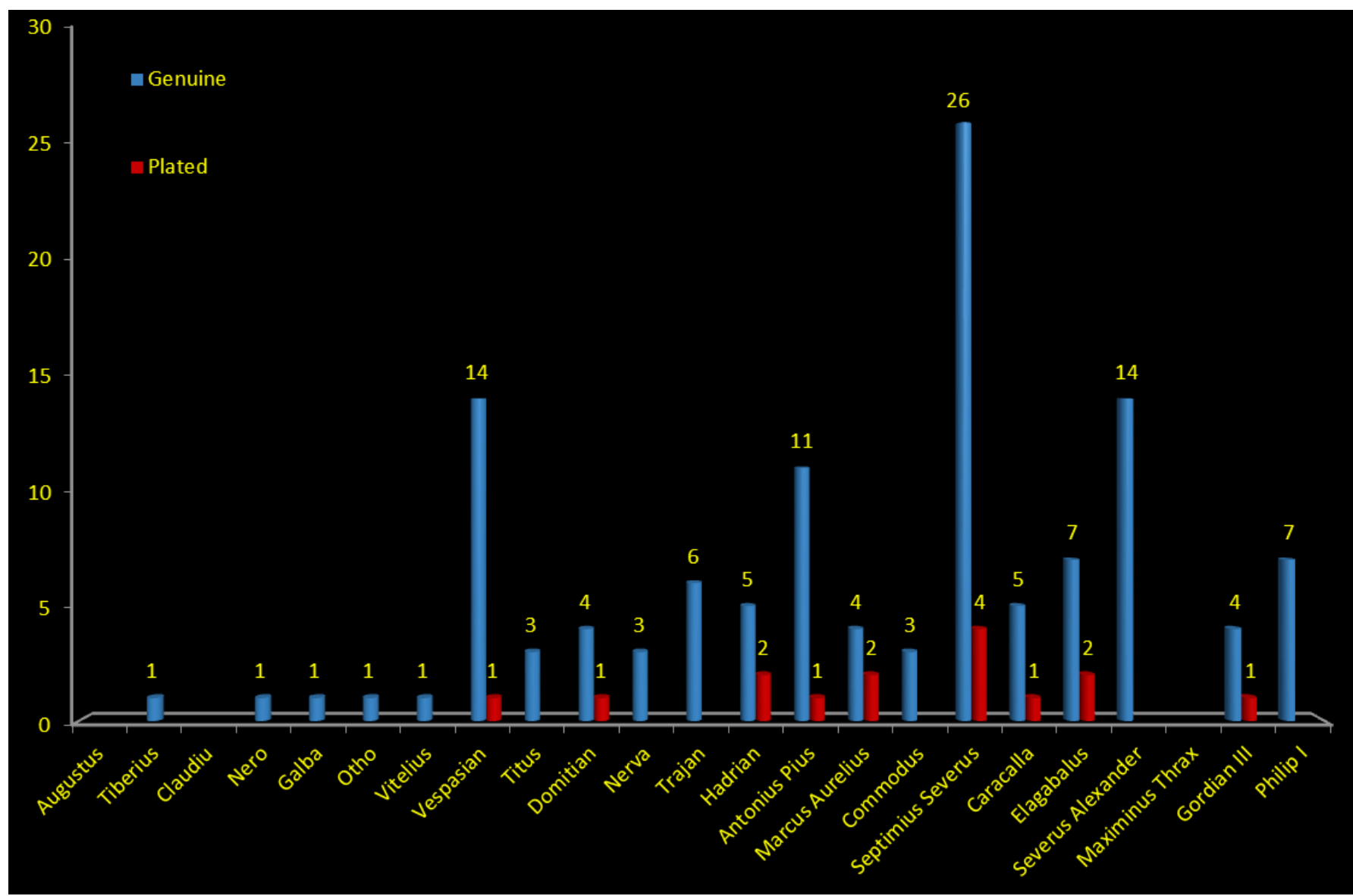

Fig.44. Graph of silver coins from Wiesbaden - number of pieces for each issuer;

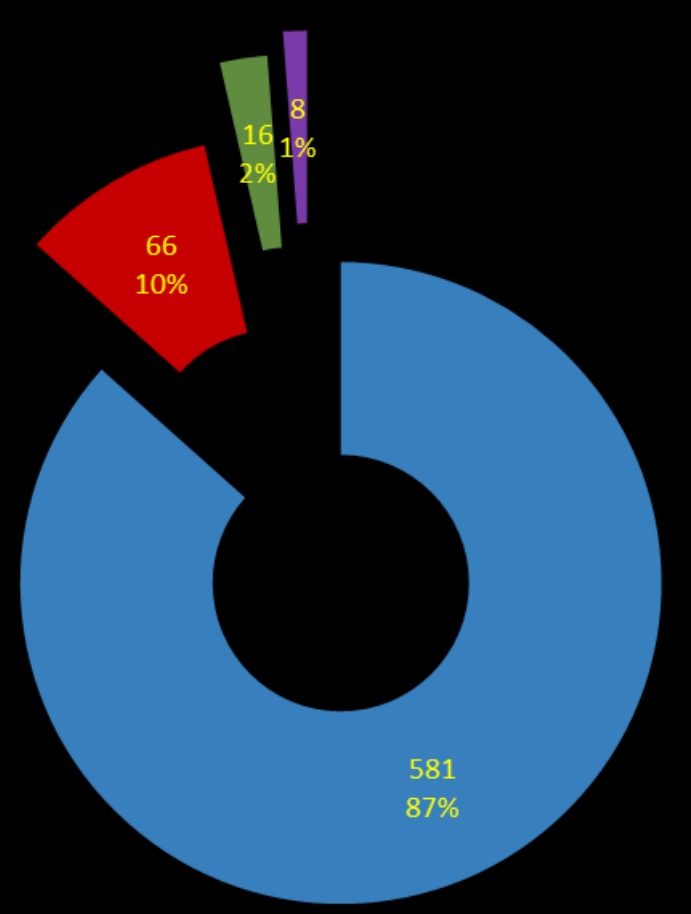

- Genuine

口 Plated

- Plated Hybrids

- Hybrids

Fig.45. Graph of silver coins from Zugmantel - number of coins and their proportion on the site;

First Roman finds were dated before the Flavian period, the stone version of the fort being build most likely during Domitian's (81-96) period ${ }^{90}$ while the vicus appeared 90 RITTERLING 1909. by the same time ${ }^{91}$.

For Wiesbaden/Aquae Mattiacorum 125 silver coins

91 TAUNUS-WETTERAU-LIMES/WIESBADE. 


\section{Studies}

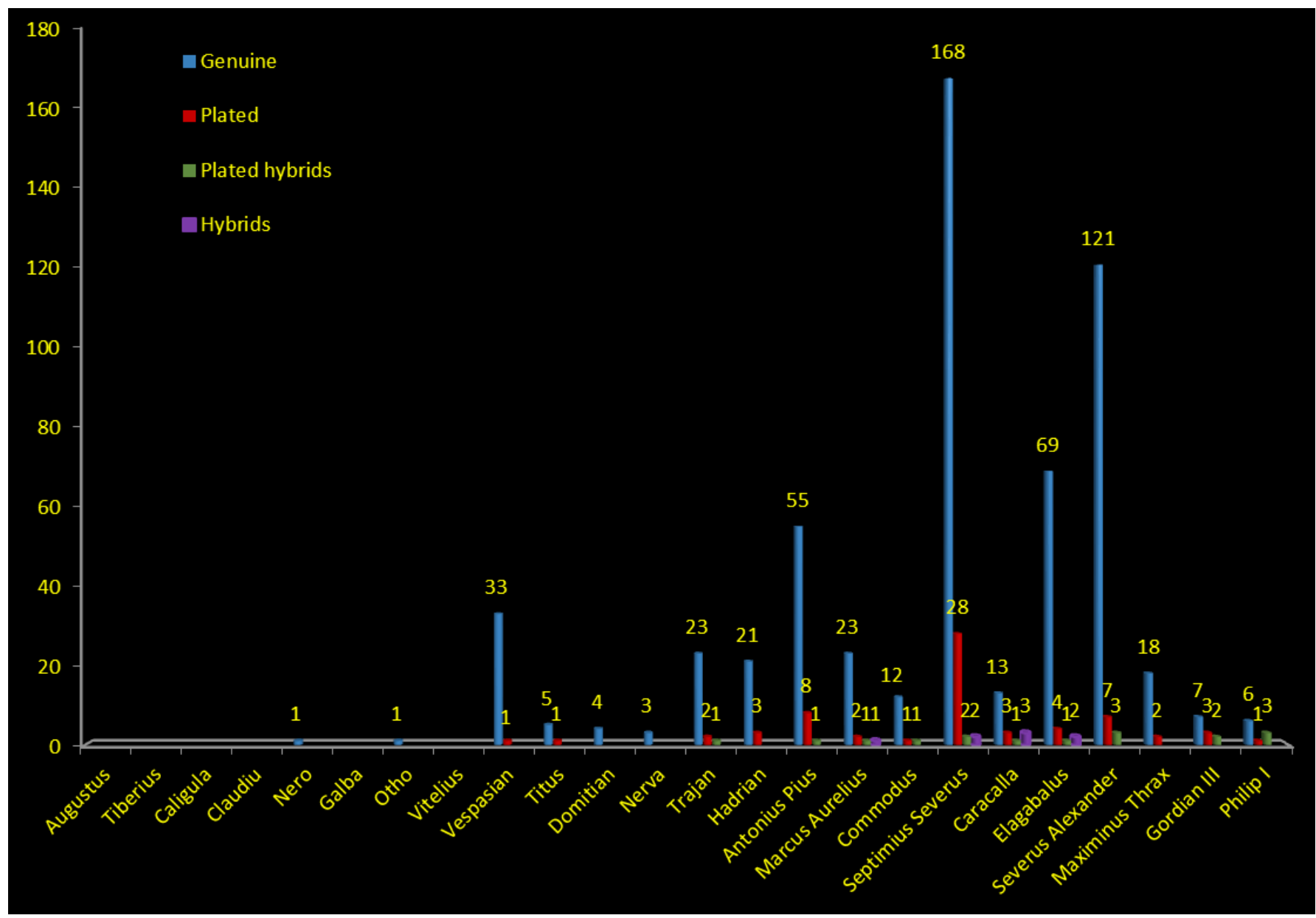

Fig.46. Graph of silver coins from Zugmantel - number of pieces for each issuer;

were found $\mathrm{d}^{92}$ as seen in Fig. 43, 110 identified as genuine with a proportion of $88 \%$ and 15 coins are plated and represent $12 \%$.

Also, looking at Fig. 44 we can observe how these coins ware dated for issuers all along the first three centuries $\mathrm{AD}$, many genuine pieces being dated during the period of Vespasian (69-79), Antonius Pius (138-161), Septimius Severus (193-211) and Severus Alexander (222-235).

The Roman fort of Zugmantel (Germany) was a strategic camp ${ }^{93}$ on the German frontier, garrisoned by the time of Caracalla (211-217) by Cohors I Treverorum equitata which will receive the extension of Maximiniana ${ }^{94}$ under the reign of Maximinus Thrax (235-238). Around this camp a civilian settlement will be built as well ${ }^{95}$.

Archaeological discoveries have brought to light 671 silver coins ${ }^{96}, 581$ with a proportion of $87 \%$ are genuine, 66 coins with a proportion of $10 \%$ are plated, 16 pieces with a proportion of $2 \%$ are plated hybrids and eight pieces representing 1\% are hybrids, as seen in Fig. 45.

In the case of silver pieces issued by each separate issuer we have Fig. 46, we can observe high coin values dated during the reign of Vespasian (69-79), for the Antoninian period and Maximinus Thrax (235-238). On the other hand, for the Severian dynasty we can see 2-3 times more

\footnotetext{
92 FMRD 1994b.

93 VICI.ORG/vici/4409

94 CIL XIII/11971.

95 SOMMER 1988

96 FMRD 1994b.
}

discovered coins, especially with images dated at Septimius Severus (193-211), Elagabalus (218-222) and Severus Alexander (222-235).

Roman fort from Heldenbergen (Germany)was situated in Germania Superior, around the fort a civilian settlement was build ${ }^{97}$.

On the site from Heldenbergen there have been identified 70 silver pieces ${ }^{98}$, Fig., 47, 68 of them representing $97 \%$ are genuine while two coins representing $3 \%$ are plated.

In Fig. 48, we can see how these pieces are distributed among reigning periods, first coins are dated at Vespasian (69-79) while most of them are dated for Septimius Severus (193-211).

At Ober-Florstadt (Germany) use to be a Roman castrum $^{99}$ that was constructed after $90 \mathrm{AD}^{100}$. First detachments that arrived here were part of Legio XXII Primigenia from Mainz, stamped bricks with their sigil being discovered here ${ }^{101}$. These units were later replaced by Cohors XXXII voluntariorum civium Romanorum ${ }^{102}$ which stayed here until the region was abandoned ${ }^{103}$.

Here there were discovered 79 silver coins ${ }^{104}$, as seen

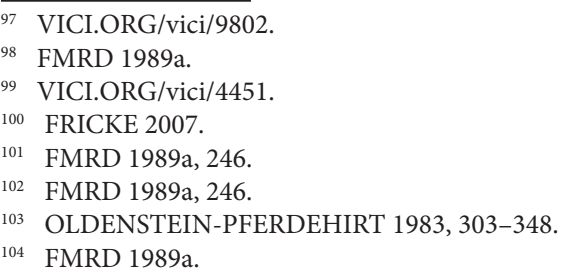




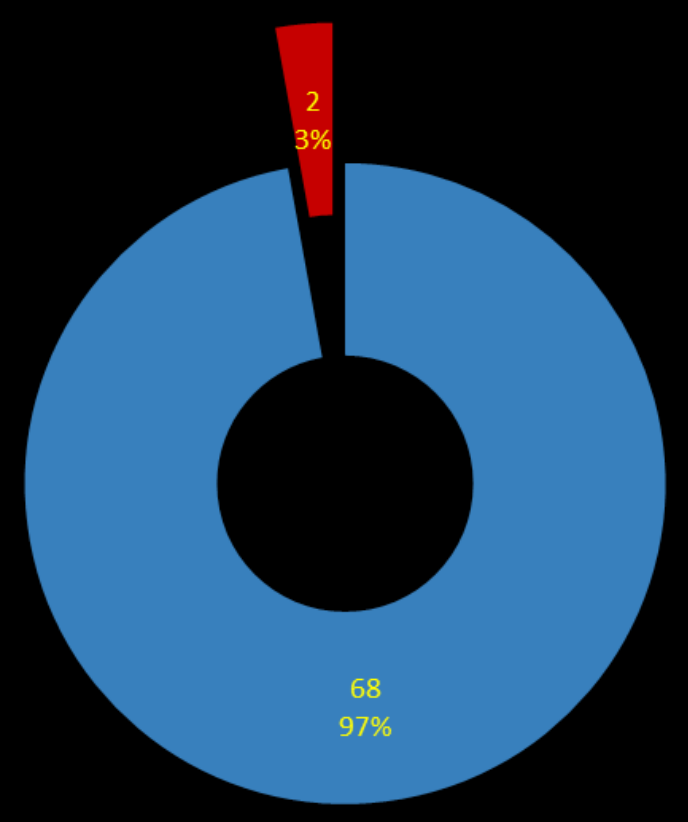

口 Genuine

口 Plated

Fig.47. Graph of silver coins from Heldenbergen - number of coins and their proportion on the site;

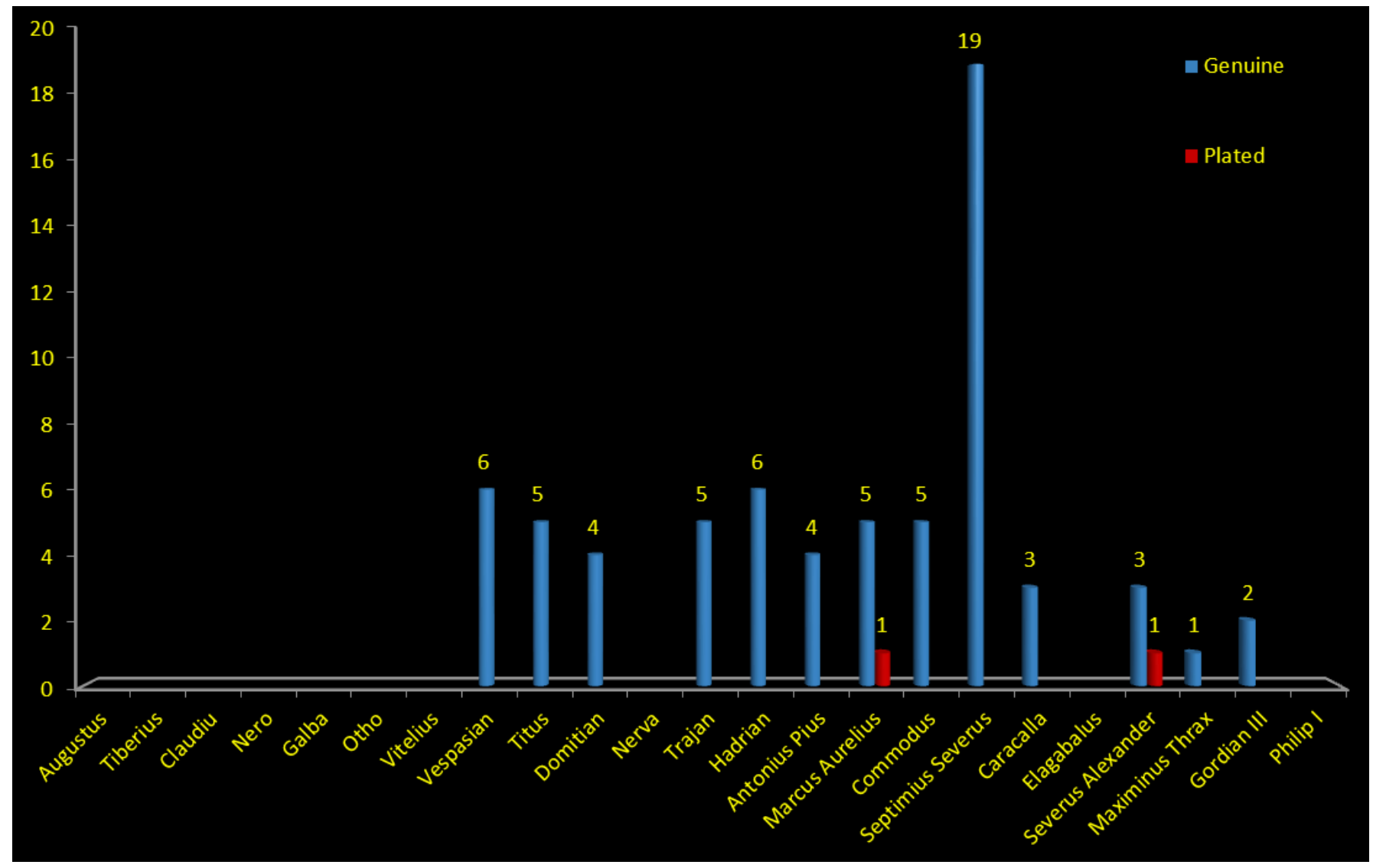

Fig.48. Graph of silver coins from Heldenbergen - number of pieces for each issuer;

in Fig. 49, 74 pieces with a proportion of $94 \%$ are genuine, four coins with a proportion of $5 \%$ are plated and one piece representing $1 \%$ is hybrid.

Fig. 50 on the other hand shows the distribution of the coins, facilitating to observe the high quantity of pieces for Septimius Severus (193-211), Elagabalus (218-222) and
Severus Alexander (222-235).

At Butzbach (Germany) used to be a Roman cohors fort which was keeping a watch on this section of the frontier ${ }^{105}$. The fort was constructed out of earth and wood around 90 AD during Domitian (81-96) by cohors II Raetorum

$\overline{105 \text { VICI.ORG/vici/4450. }}$ 


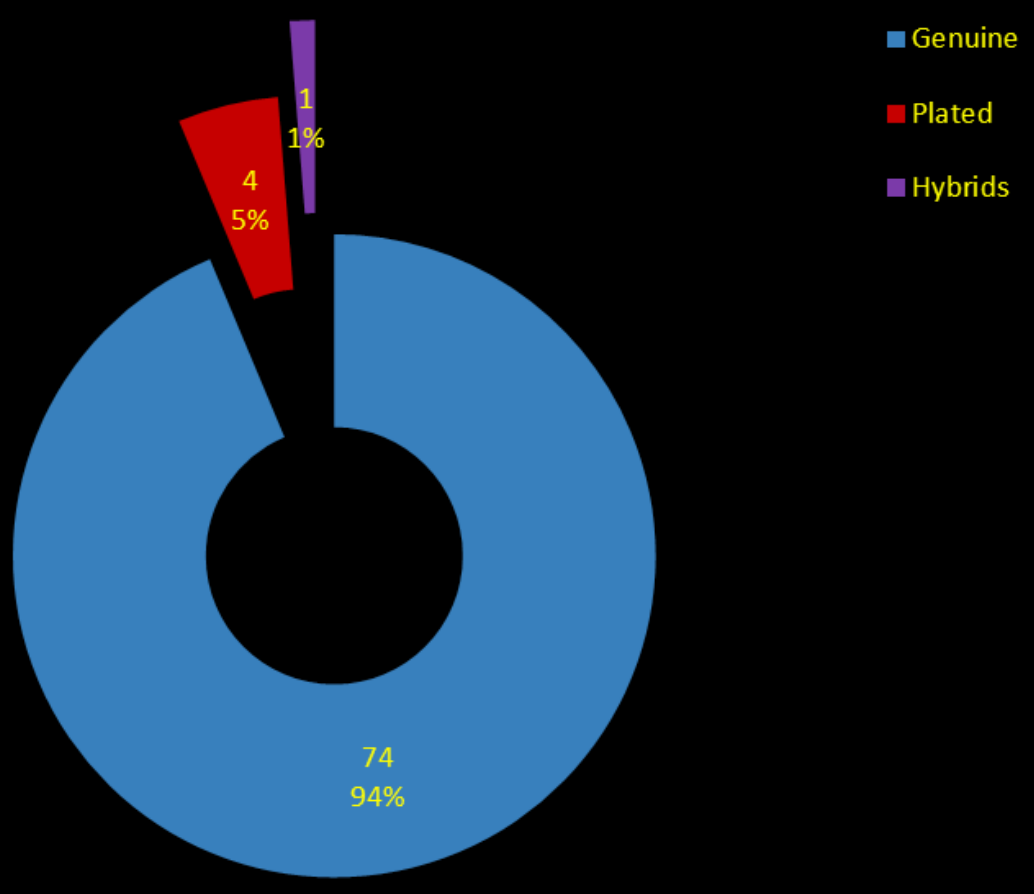

Fig.49. Graph of silver coins from Ober-Florstadt - number of coins and their proportion on the site;

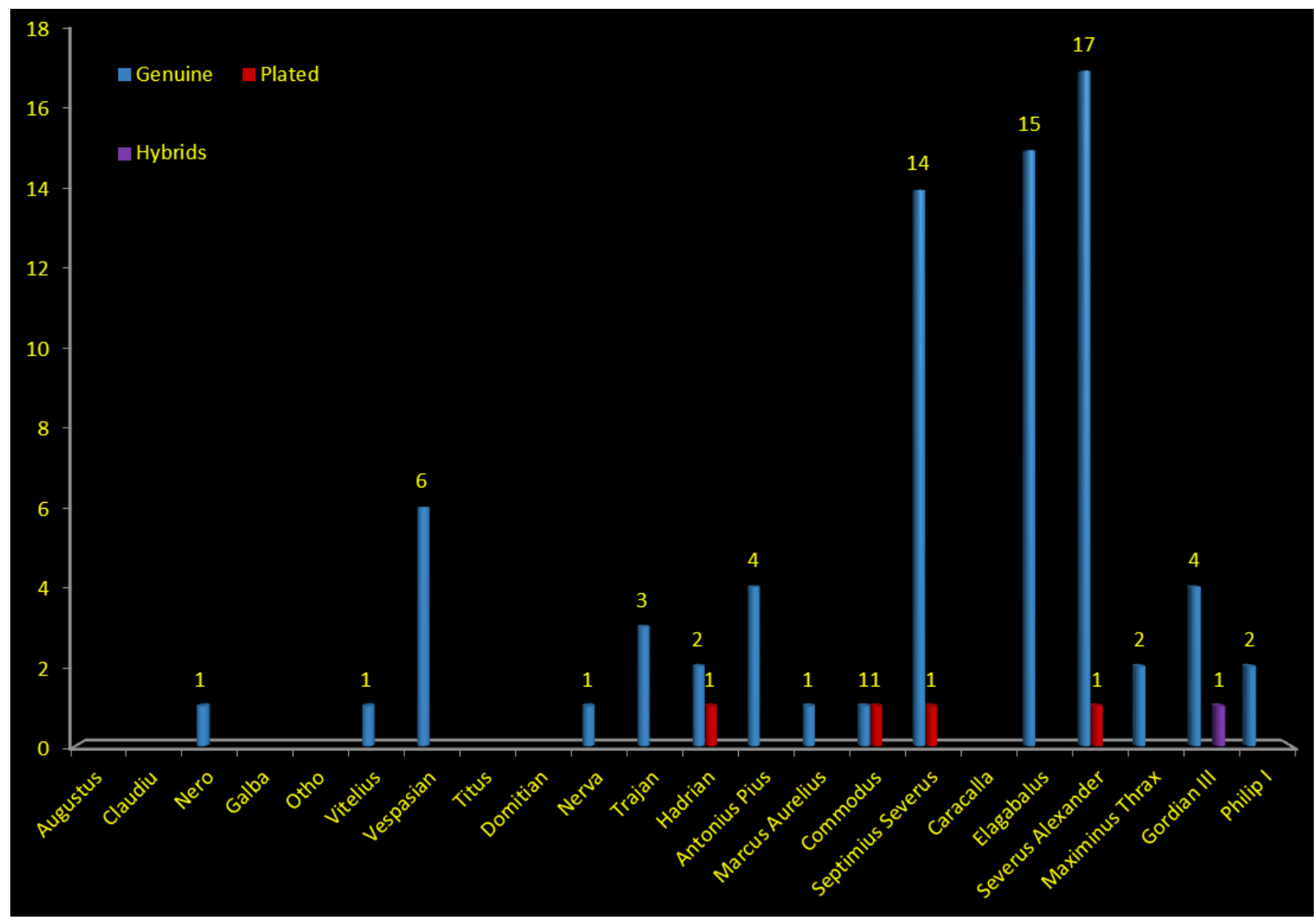

Fig.50. Graph of silver coins from Ober-Florstadt - number of pieces for each issuer;

civium Romanorum $^{106}$, later around $135 \mathrm{AD}$ the unit will be $\vdots$ replaced by cohors II Augusta Cyrenaica equitata which will
${ }_{106}$ KORTÜM 1998, 5-65. 


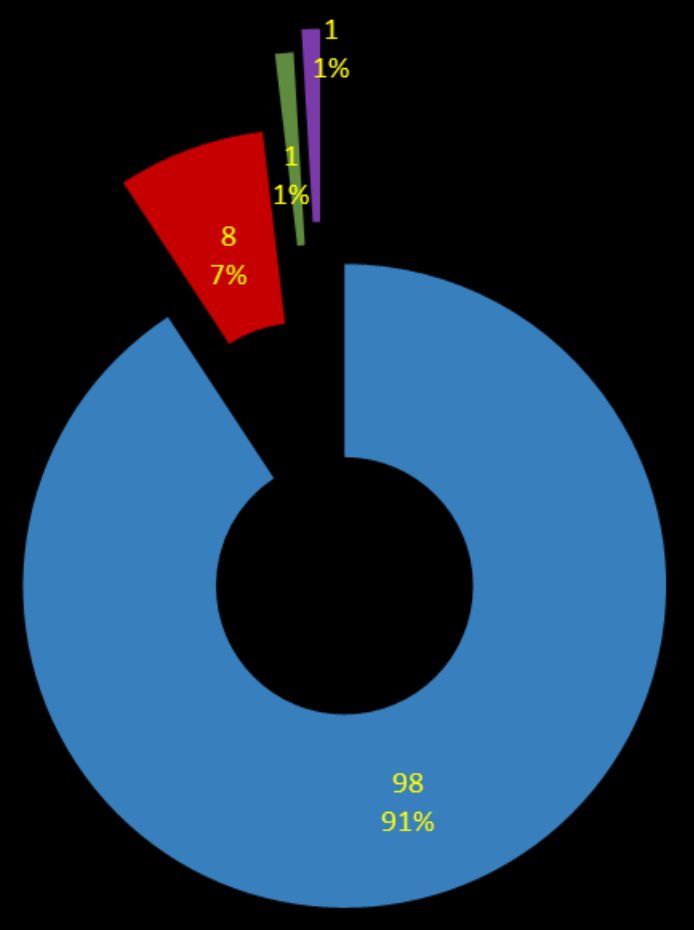

- Genuine

口Plated

- Plated hybrids

CHybrids

Fig.51. Graph of silver coins from Butzbach - number of coins and their proportion on the site;

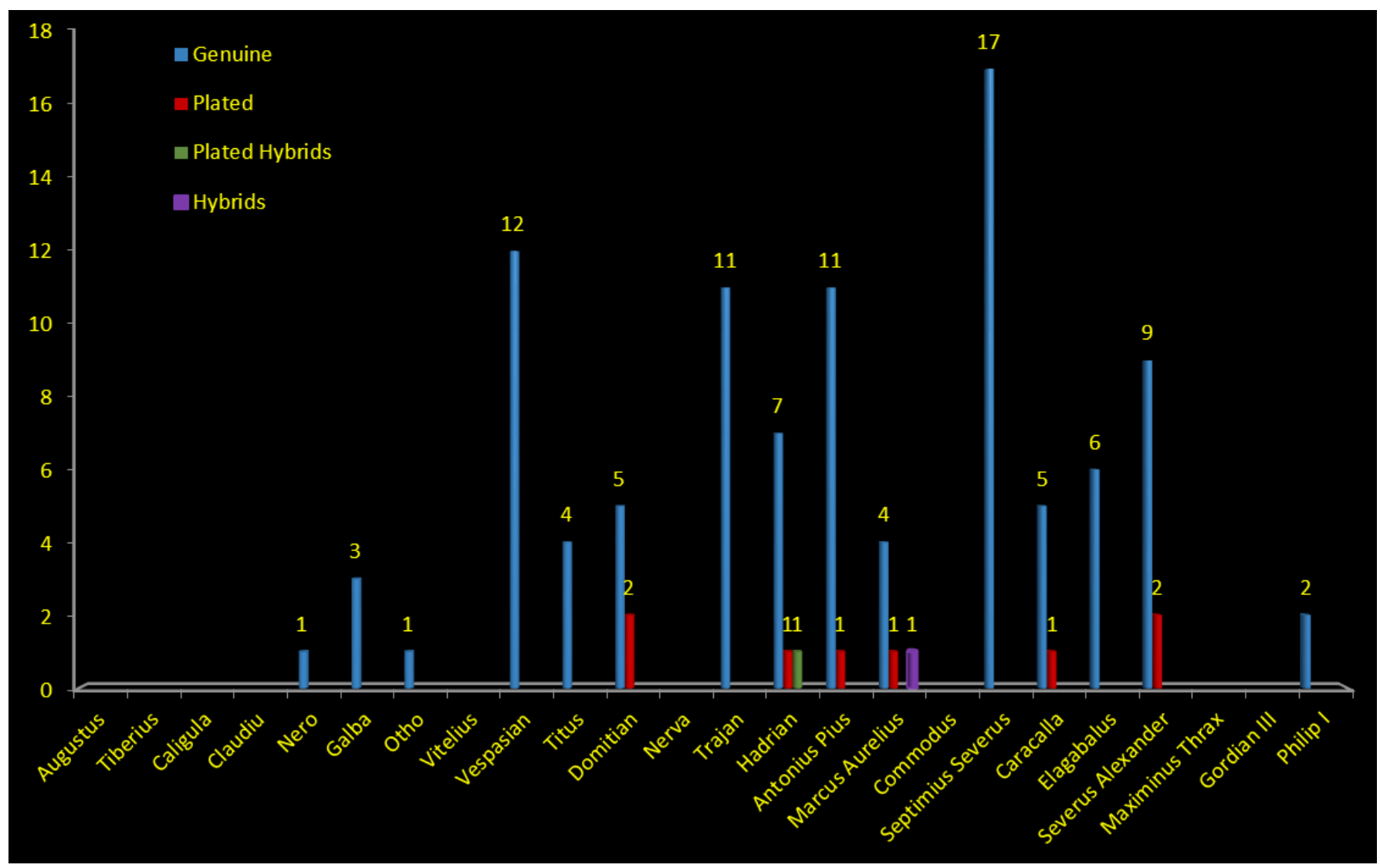

Fig.52. Graph of silver coins from Butzbach - number of pieces for each issuer;

In the second half of the II century AD the fort was further expanded towards south since a new unit was added, alla Moesica felix torquata ${ }^{107}$.

$\frac{\text { After stud }}{107 \text { CIL XIII/7433. }}$
108 silver coins were discovered at Butzbach ${ }^{108}, 98$ pieces which represent $91 \%$ are genuine, eight coins representing $7 \%$ are plated, one coin with $1 \%$ is a plated hybrid and another piece with $1 \%$ is a hybrid, as seen in Fig. 51. 108 FMRD 1989a. 


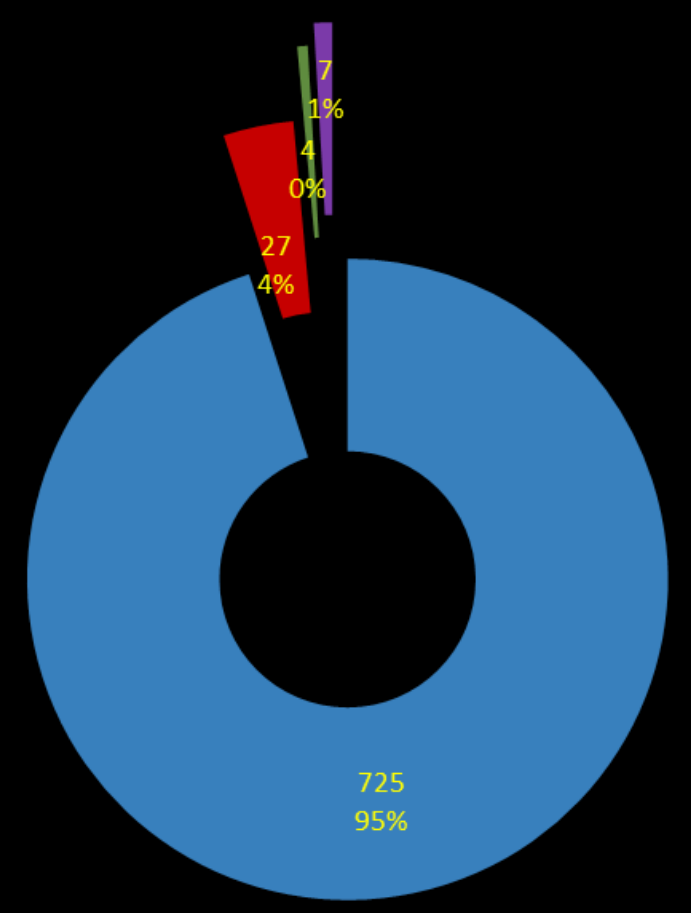

口 Genuine

口 Plated

- Plated hybrids

- Hybrids

Fig.53. Graph of silver coins from Augusta Treverorum - number of coins and their proportion on the site;

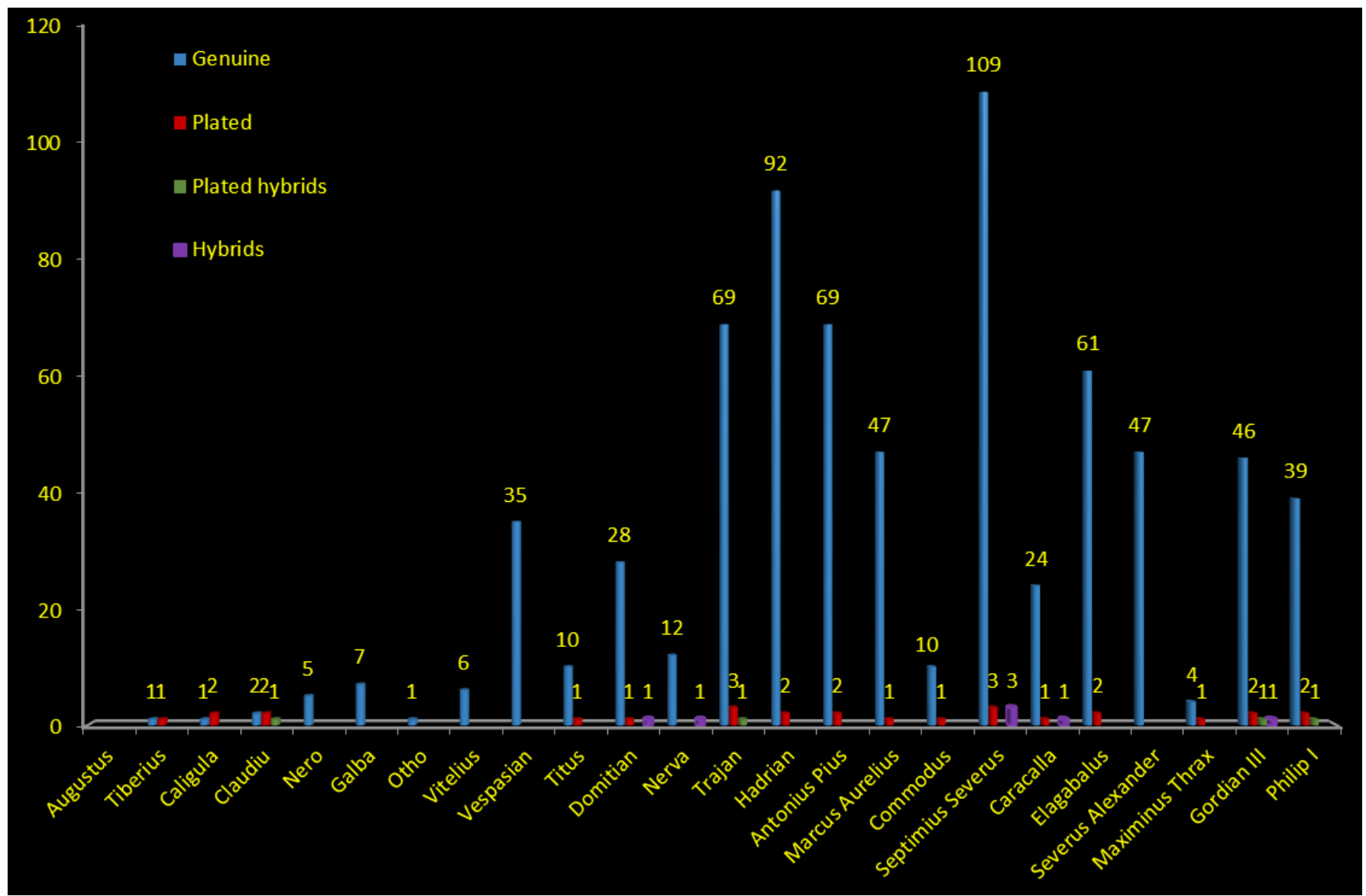

Fig.54. Graph of silver coins from Augusta Treverorum - number of pieces for each issuer;

Second graph represented by Fig. 52 shows how the pieces were distributed along time periods, more of them were dated for Vespasian (69-79), Trajan (98-117), Antonius Pius (138-161), Septimius Severus (193-211) and Severus
Alexander (222-235).

The town of Augusta Treverorum (Trier, Germany) ${ }^{109}$ was founded by Augustus (27BC-AD14) 109 VICI.ORG/vici/2799. 


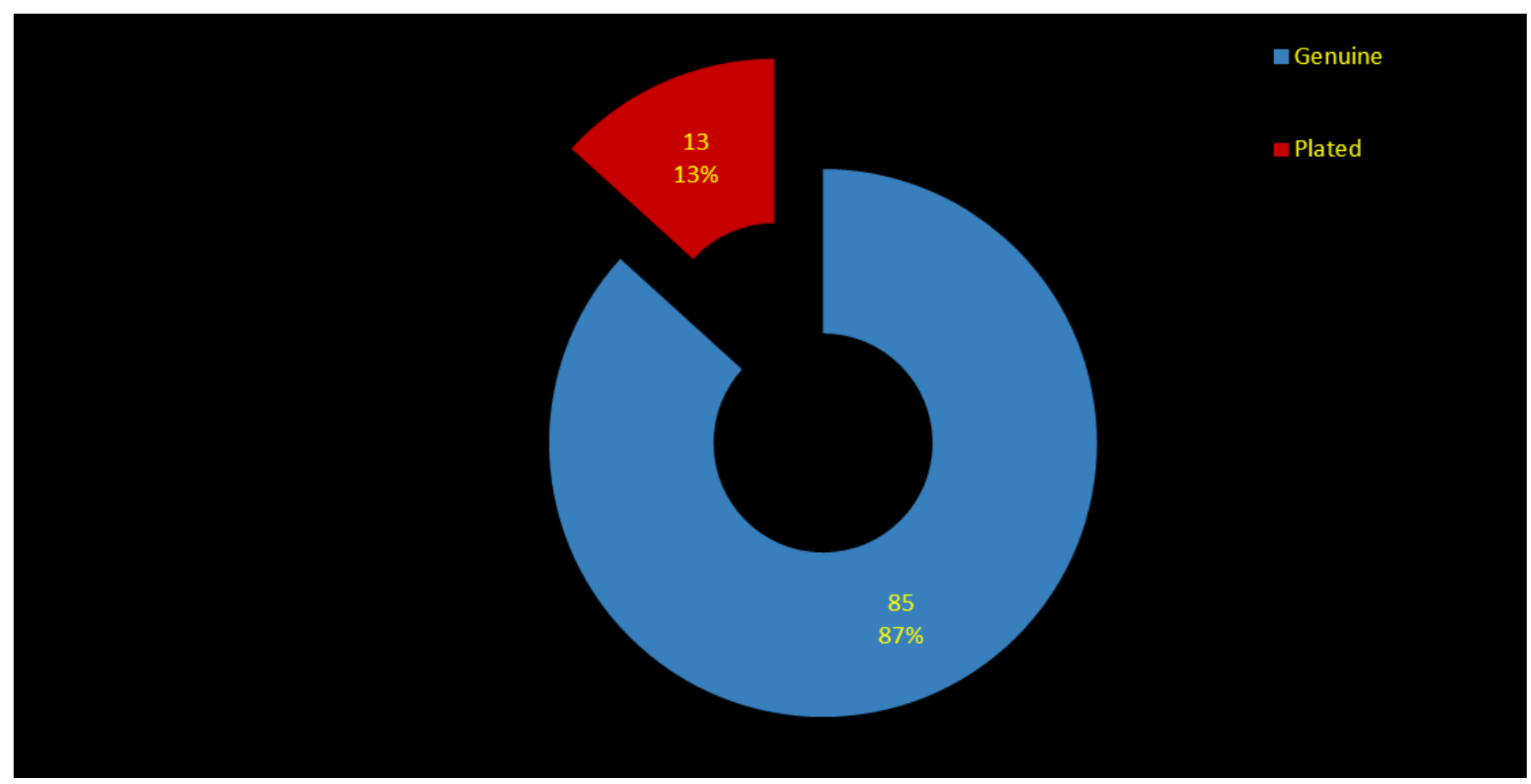

Fig.55. Graph of silver coins from Marcodurum - number of coins and their proportion on the site;

around 18/17 $\mathrm{BC}^{110}$ in the future Roman province of Gallia Belgica. By the same time a bridge was built over the Moselle river as part of the new road network for the area ${ }^{111}$.

In one of Tacitus reports dated at $69 \mathrm{AD}^{112}$ the town of Trier is mentioned with the title of Colonia Treverorum ${ }^{113}$.

Fig. 53 shows the 763 silver coins ${ }^{114}$ discovered here, 725 representing 95\% from the total amount are genuine, 27 pieces representing $4 \%$ are plated, four coins with $0,5 \%$ are plated hybrids and six coins are hybrids forming the last $0,5 \%$.

On the other hand, Fig. 54 shows very high values for genuine pieces dated during the Flavian, Antoninian and Severian periods, especially for Hadrian (117-138) and Septimius Severus (193-211).

Marcodurum was a Roman vicus close to the Rhine and modern town of Mariaweiler-Hoven (Germany) ${ }^{\mathbf{1 1 5}}$. According to Tacitus, close by this settlement, Roman troops were defeated by the Batavians in $69 \mathrm{AD}^{116}$.

On the site of Mariaweiler-Hoven/Marcodurum there have been identified 98 silver coins ${ }^{117}$. As seen in Fig. 55, 85 pieces which represent $87 \%$ are genuine while 13 coins representing $13 \%$ are plated.

Also in Fig. 56 we can observe high values for number of coins dated for Vespasian (69-79), Antonius Pius (138161) and Septimius Severus (193-211).

Roman vicus from Nörvenich (Germany) was present between the I and IV centuries $\mathrm{AD}^{118}$, many ceramic pieces, bricks, roof tiles and pottery fragments being visible

110 HEINEN 1984, 41. CÜPPERS 1990, 579.

111 HEINEN 1984, 40. NEYSES-EIDEN 2009, 50.

112 TACITUS, Historiae 4, 72.

113 TACITUS, Historiae 4, 72.

114 FMRD 2004. FMRD 2006b. FMRD 2007.

115 VICI.ORG/vici/23320.

116 TACITUS, Historien 4, 28: Caesae cohortes eorum in vico Marcoduro incuriosius agentes, quia procul ripa aberant.

117 FMRD 2008.

118 VICI.ORG/vici/14220. at the surface of the ground ${ }^{119}$.

Around the researched area there have been found 106 silver pieces ${ }^{120}, 97$ of them which represent $92 \%$ are genuine while nine pieces representing $8 \%$ are plated, as seen in Fig. 57.

In the case of coin distribution, Fig. 58, most of the pieces are dated for Antonius Pius (138-161), Septimius Severus (193-211), Elagabalus (218-222) and Severus Alexander (222-235).

Around $19 \mathrm{BC}$ the tribe of the Uubii was forced to move on the western shore of the Rhine, here the founded the new settlement of Oppidum Ubiorum ${ }^{121}$. In time, the settlement will be influenced by the Roman authorities becoming Colonia Agrippinensium, the future city of Köln (Germany) ${ }^{122}$.

Between 9-30 $\mathrm{AD}^{123}$ Legio I Germanica and Legio XX Valeria Victrix ${ }^{124}$ stayed here, after $30 \mathrm{AD}$ Legio I was transferred at Bonna (Bonn) and Legio XX at Novaesium (Neuss) $)^{125}$. No other legion will be brought at Köln, but the town will remain the military headquarters for Germania Inferior ${ }^{126}$

Around the area of Köln/Colonia Claudia Ara Agrippinensium, there were discovered 91 silver coins ${ }^{127}$ as seen in Fig. 59, from which 86 pieces representing 95\% were genuine, three coins representing $3 \%$ are plated, one plated hybrid and one hybrid piece both representing in total $2 \%$.

On the other hand, in Fig. 60 we observe the distribution of the coins, higher values are easy to notice for

\footnotetext{
119 HGV-NOERVENICH.DE.

120 FMRD 2008.

121 HEINRICHS 1996.

122 VICI.ORG/vici/104.

123 KEMKES 2006, 46.

124 TACITUS: Annales. I, 39,1.

125 HORN 2003, 54.

126 KUNOW 2002, 27-109. ECK 2005, 63-126.

127 FMRD 1984.
} 


\section{Studies}

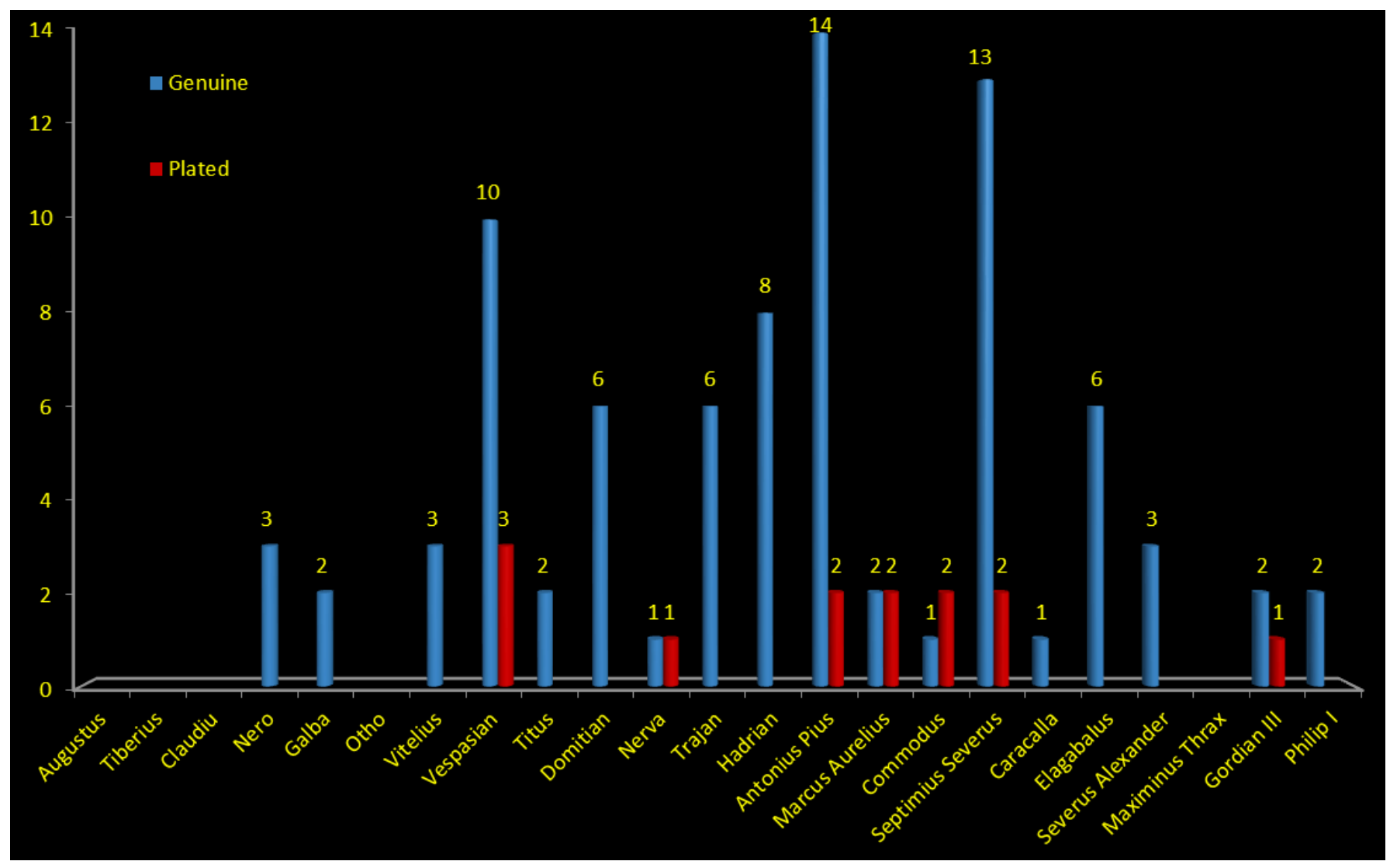

Fig.56. Graph of silver coins from Marcodurum - number of pieces for each issuer;

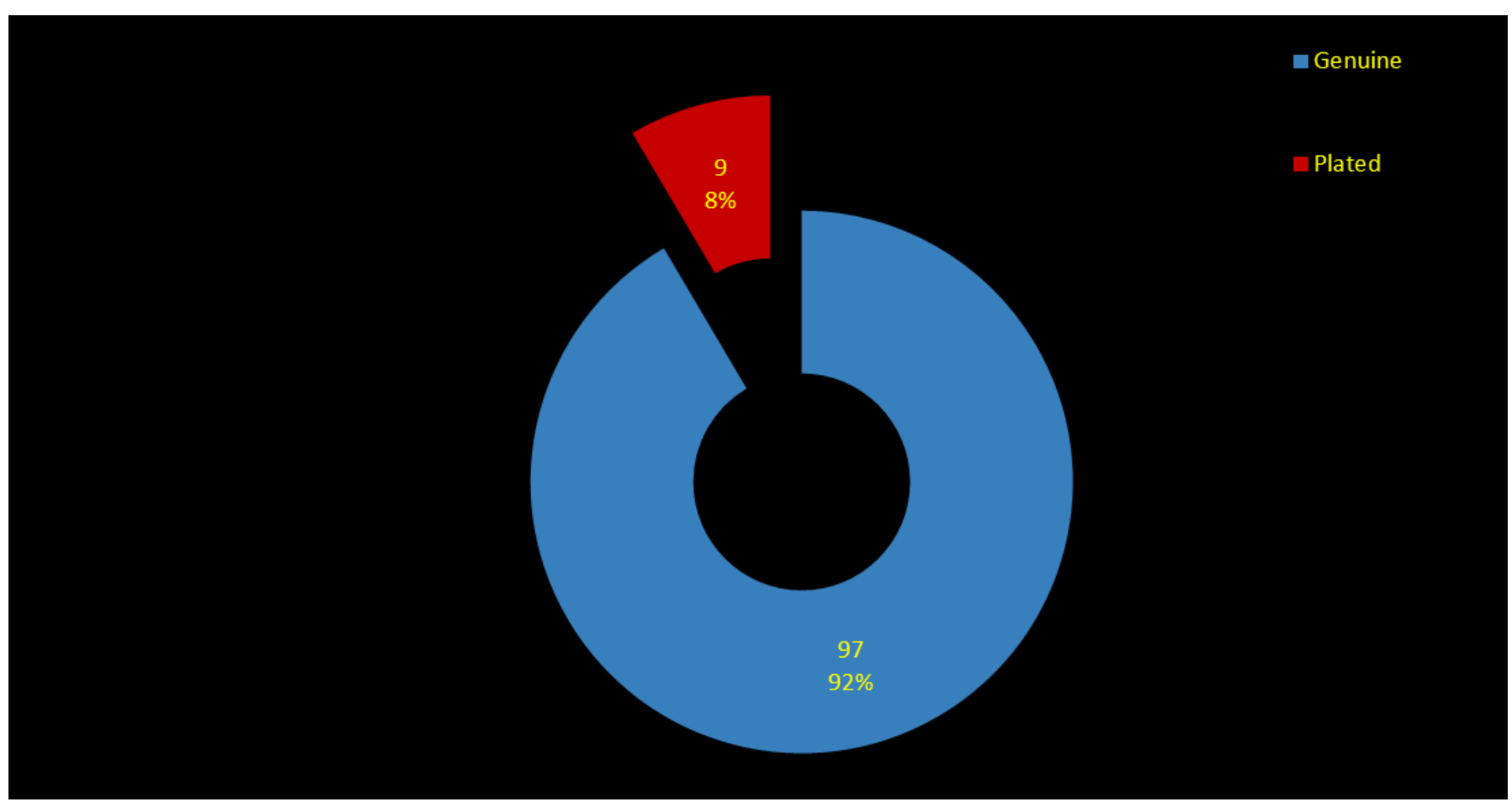

Fig.57. Graph of silver coins from Nörvenich - number of coins and their proportion on the site;

the period of Vespasian (69-79), Antoninian, Severian, most especially during the reign of Septimius Severus (193-211) and Severus Alexander (222-235).

Around 16 BC, Roman soldiers constructed a fort on the road between Köln and Xanten, at Novaesium (Neuss,
Germany) ${ }^{128}$. The fort was influenced by the Batavian revolt from $70 \mathrm{AD}$, Legio XVI Gallica which fought in the area was replaced by Legio VI Victrix ${ }^{129}$ which also raised the stone

$\overline{128}$ VICI.ORG/vici/366.

129 RITTERLING 1925, 1598-1614. RÜGER 1984, 40-44. 


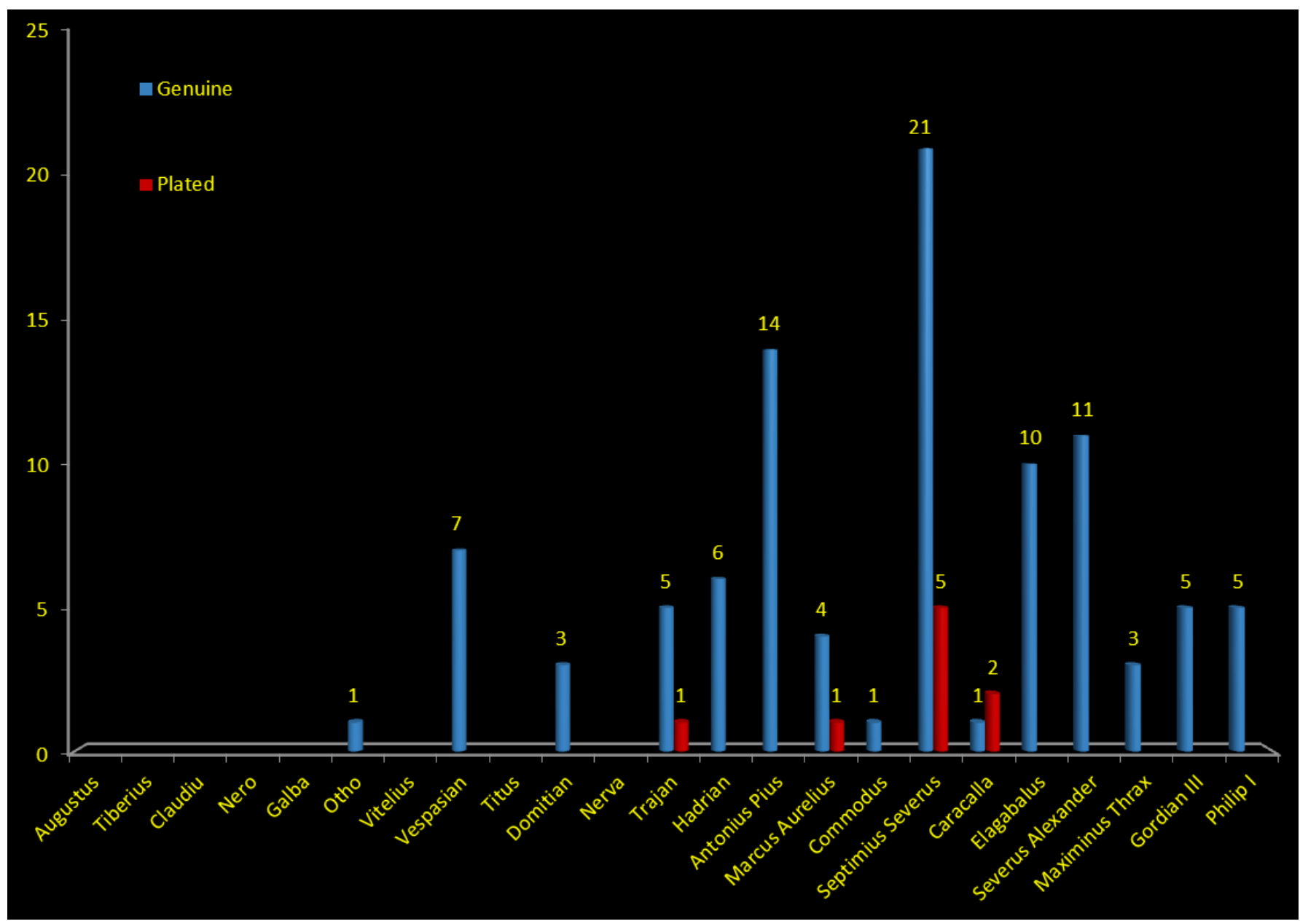

Fig.58. Graph of silver coins from Nörvenich - number of pieces for each issuer;

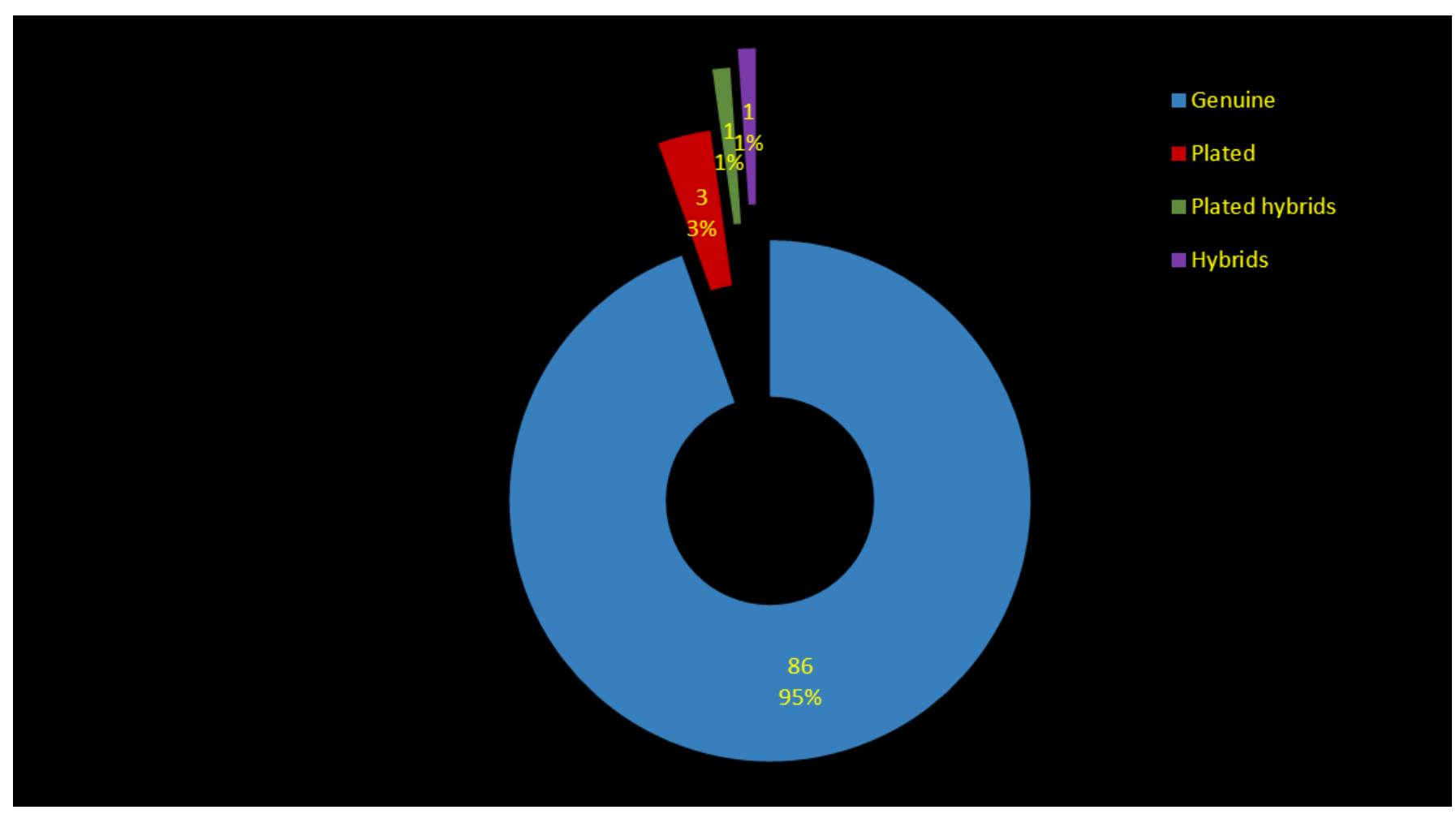

Fig.59. Graph of silver coins from Colonia Agrippinensium - number of coins and their proportion on the site;

phase of the fort, the old one being damaged in the war ${ }^{130}$.

130 LIVIUS.ORG/ARTICLES/PLACE/NOVAESIUM-NEUSS.
During the Flavian period the region was calm, therefor the legions were moved to another sector and the 


\section{Studies}

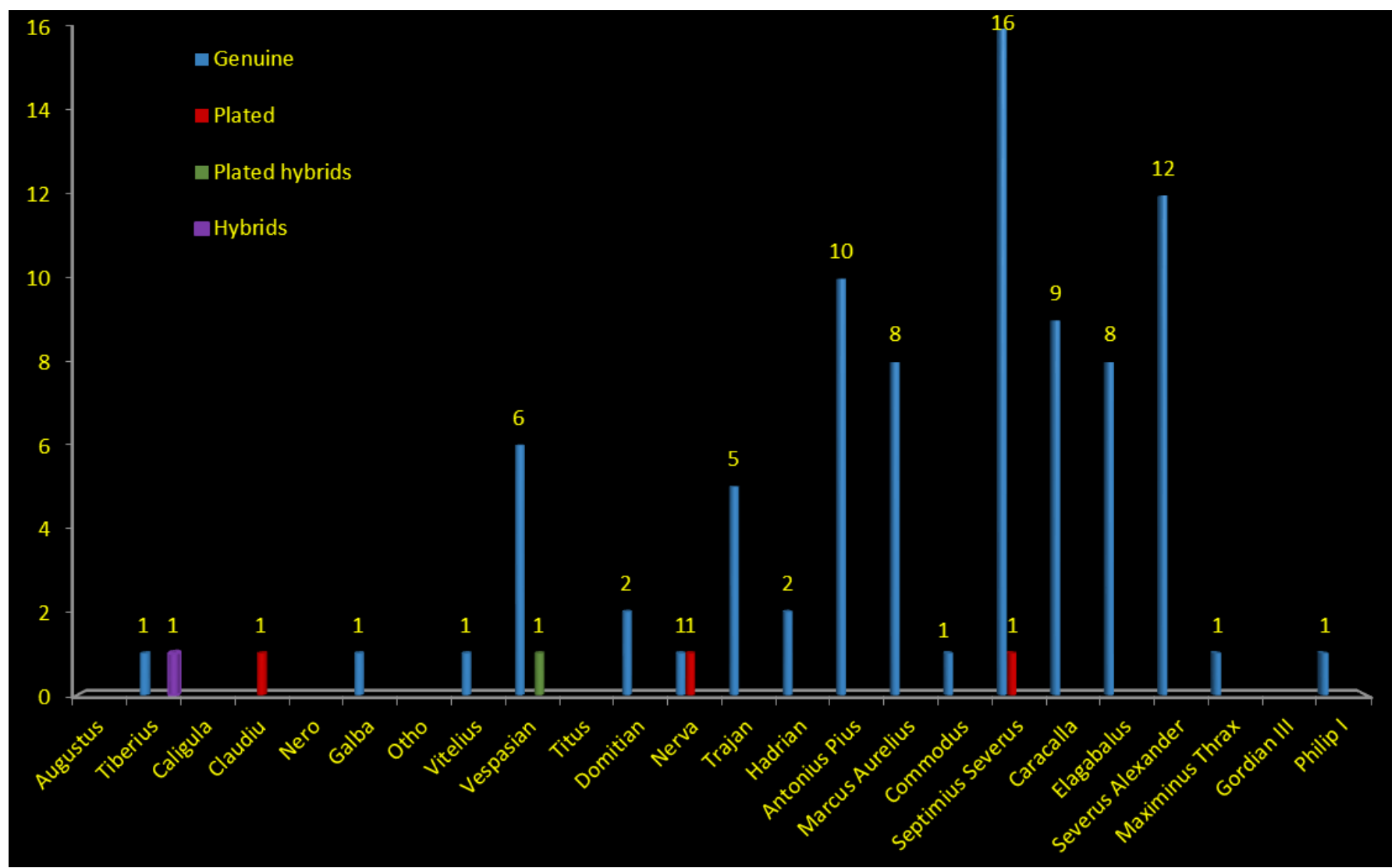

Fig.60. Graph of silver coins from Colonia Agrippinensium - number of pieces for each issuer;

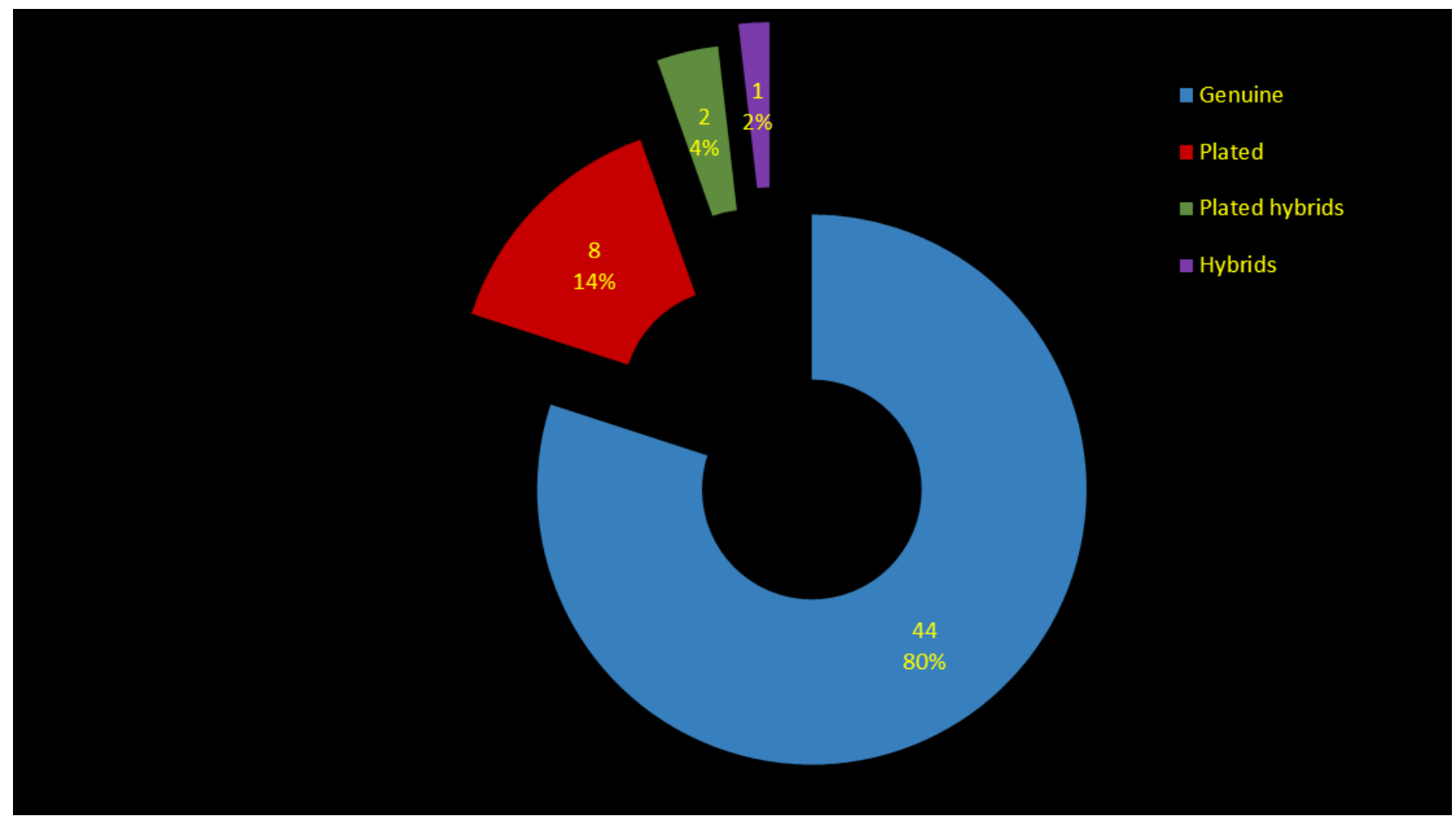

Fig.61. Graph of silver coins from Novaesium - number of coins and their proportion on the site;

camp was garrisoned by an auxiliary unit which hold the fort well into the IV century ${ }^{131}$.

As we can see in Fig. 61, around Neuss/Novaesium

131 MÜLLER 1984. there have been identified 65 silver pieces ${ }^{132}, 44$ of them representing $80 \%$ are genuine, eight coins representing $14 \%$ are plated, two pieces with $4 \%$ are plated hybrids and one coin with $2 \%$ is a hybrid. 


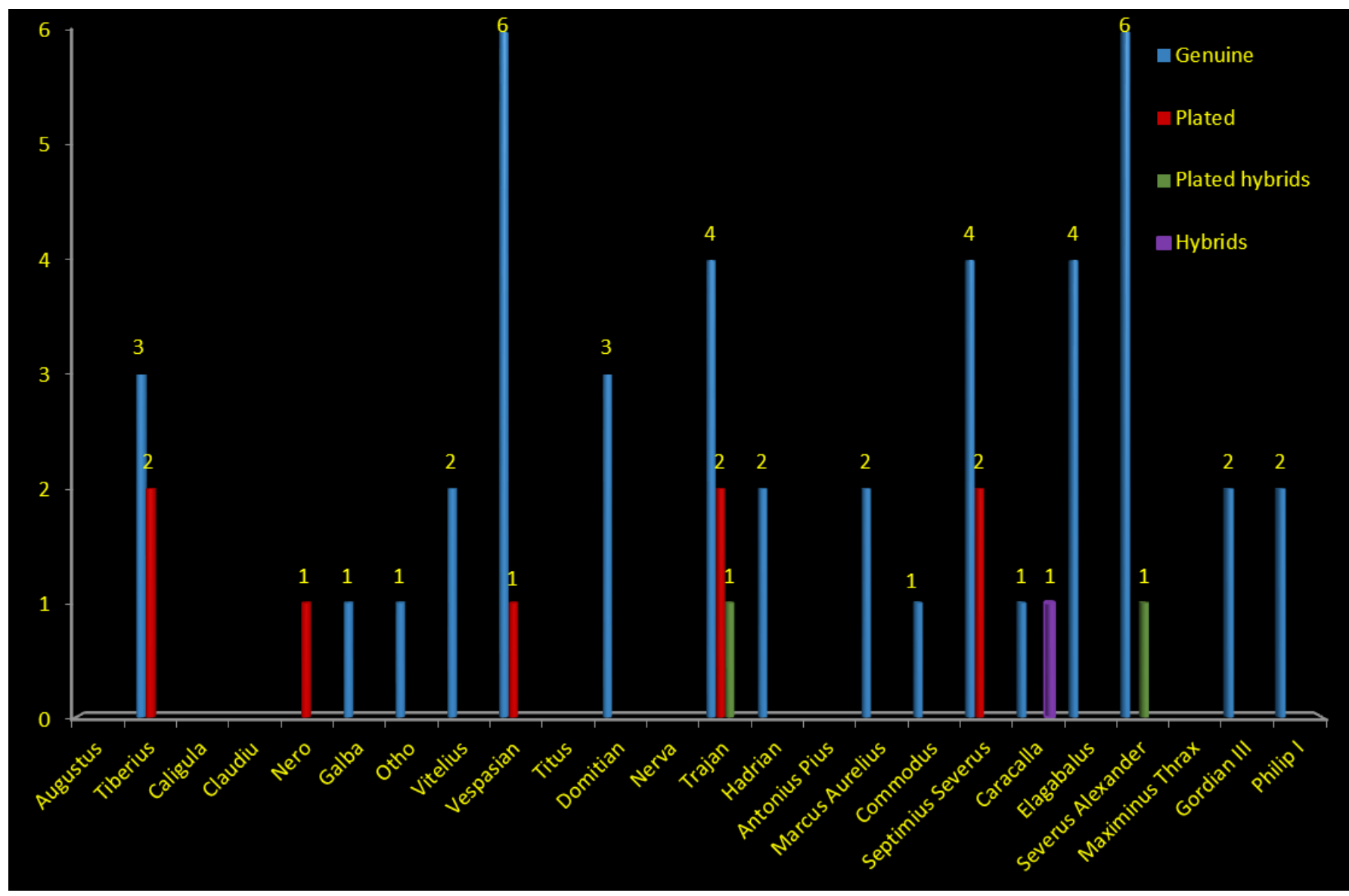

Fig.62. Graph of silver coins from Novaesium - number of pieces for each issuer;

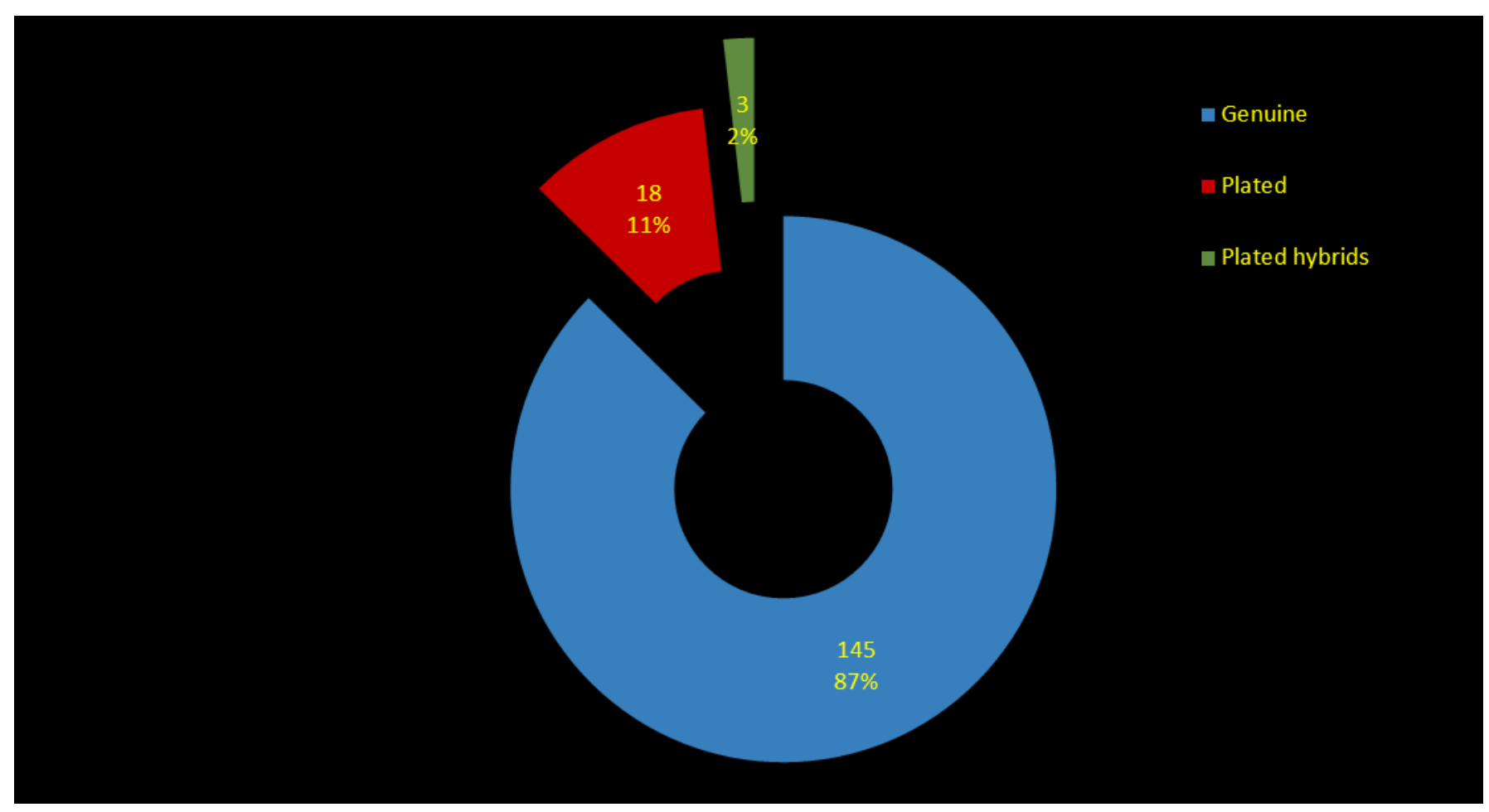

Fig.63. Graph of silver coins from Noviomagus - number of coins and their proportion on the site;

Unfortunately, Fig. 62 which shows the distribution of these pieces does not show an accurate situation because of the small number of coins identified and of the large historical period for which they have been dated.

On a plateau close to Noviomagus, Nijmegen

(Holland) a legionary fort was placed during the reign of 


\section{Studies}

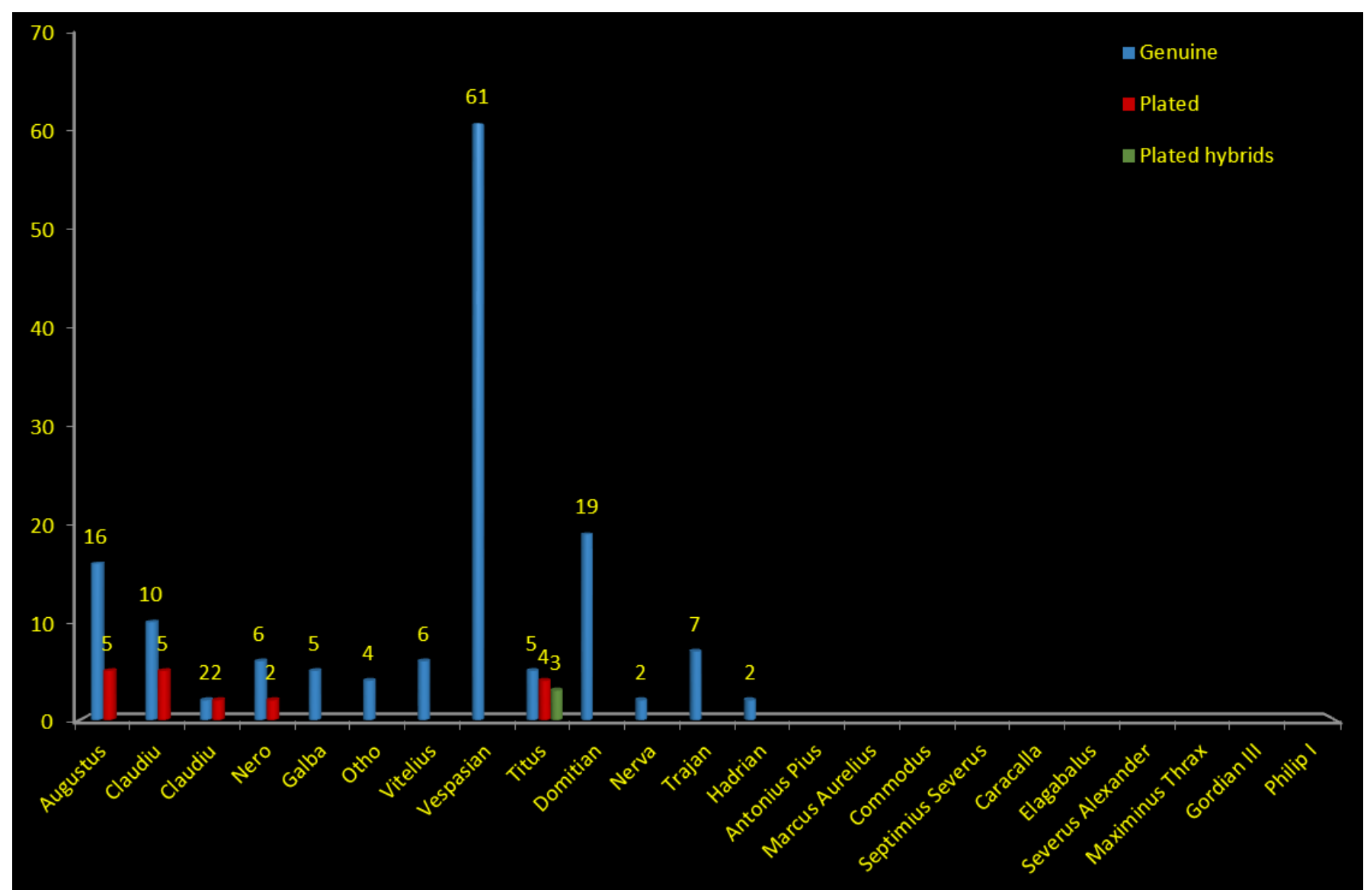

Fig.64. Graph of silver coins from Noviomagus - number of pieces for each issuer;

Augustus (27BC-AD14) which served as garrison for Legio $X$ Gemina $^{133}$ supported by the many graffiti, stamp bricks and inscriptions ${ }^{134}$. The fort was quite spacious and could garrison many troops ${ }^{135}$, archaeological discoveries proven the fact that it was able to sustain between two and three legions ${ }^{136}$.

The legion was transferred in $104^{137}$, in its place just some detachments from alae Vexillatio Britannica remained, but towards the middle of the II century the fort was completely abandoned ${ }^{138}$.

For the site of Nijmegen/Noviomagus, Fig. 63, there have been identified 166 silver pieces ${ }^{139}, 145$ representing $87 \%$ of the total amount of coins were identified as genuine, 18 coins with $11 \%$ are plated and three coins with $2 \%$ are plated hybrids.

For coin distribution, we have Fig. 64 where we can observe how the pieces were assigned according to the issuer they represent. All coins were dated only for the I and II century AD, most of them during the reign of Vespasian (6979).

\section{MONETARY SITUATION AT REGIONAL LEVEL:}

If we want to extract more useful information from the graphs we need to dig a little deeper and play with the

${ }_{133}$ KEMMERS 2006, 16. VICI.ORG/vici/84.

134 HAALEBOS 2000, 18.

135 HAALEBOS 1995, 29. VICI.ORG/vici/69.

136 KEMMERS 2006, 16.

137 KEMMERS 2006, 119. SCHÖNBERGER 1985, 449;

138 HAALEBOS 1995, 87-88.

139 KEMMERS 2006. numbers. Thus, because of historical and geographical influences all studied sites were divided into three regions.

Sites from Roman provinces of Noricum and Raetia will form the Upper Danube area, those from Germania Superior will remain in the Upper Rhine area while sites from Germania Inferior and Gallia Belgica will form the Lower Rhine area.

Hybrid coins were added to genuine pieces for these graphs since they were made by striking and therefor guaranteed Rome, while plated hybrids were added to plated pieces.

Armed with these areas, new graphs were successfully formed. For Upper Danube area, we have Fig. 65 regarding genuine pieces and Fig. 66 for plated coins, for Upper Rhine region we have Fig. 68 and Fig. 69 while for Lower Rhine area we have Fig. 71 and Fig. 72. For comparing the situation of both genuine and plated coins for a region we have Fig. 67, Fig. 70 and Fig. 73.

For a better showing some issuers with shorter periods of reign were compiled to present a more accurate situation. That is why we have the 54-69 time frame which includes Nero (54-68), Galba, Otho and Vitelius, the last three ruling between 68-69 AD. This new layout was chosen so that short periods of reign do not influence the overall results, only exceptions that are admitted are for Severian dynasty when a lot of coins were issued in a brief period.

As we can see in Fig. 65, for Upper Danube area coins were dated from Nero (54-68) until the beginning of the Military Anarchy period. 


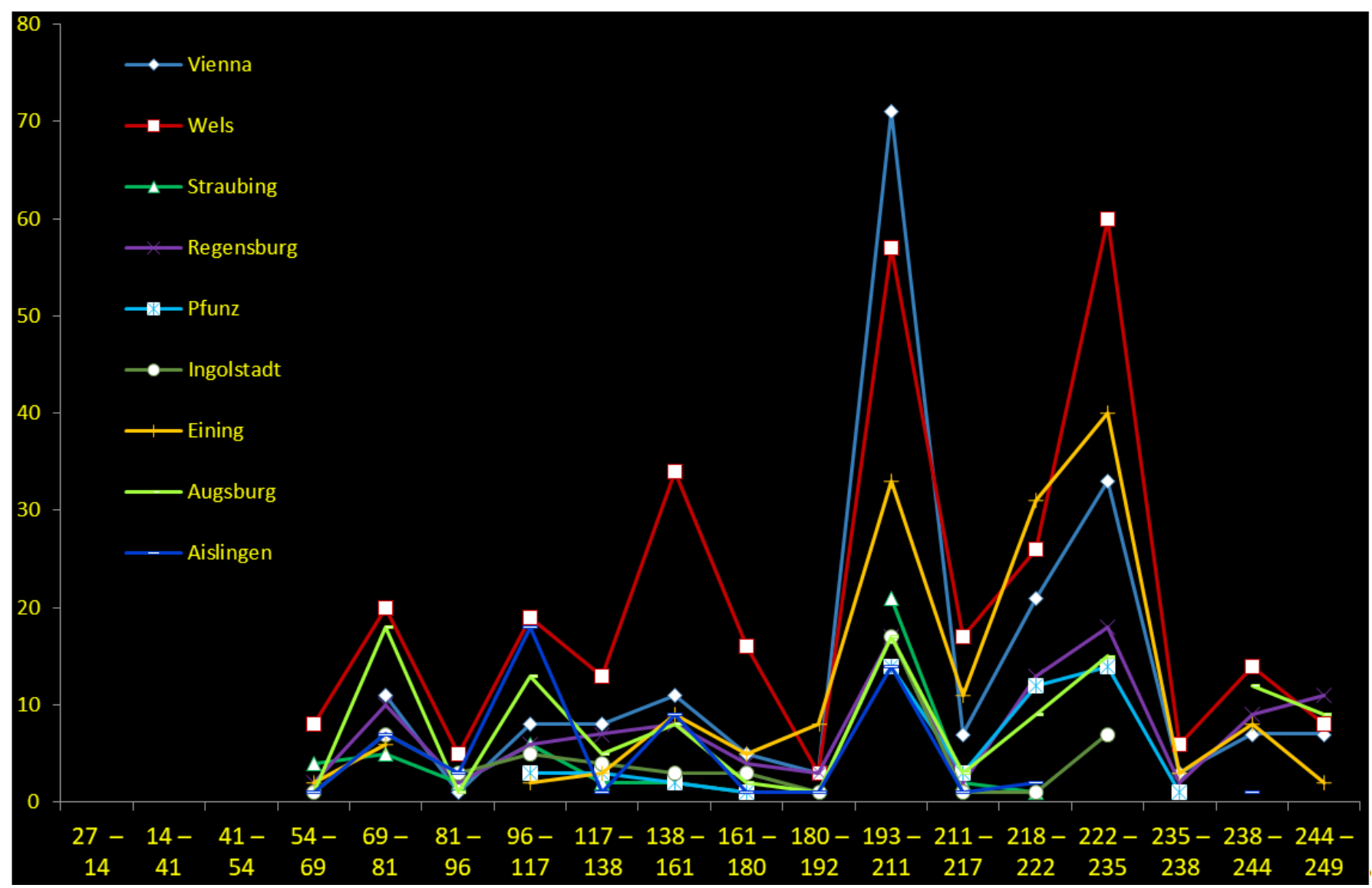

Fig.65. Graph with number of silver coins for Upper Danube region - genuine pieces;

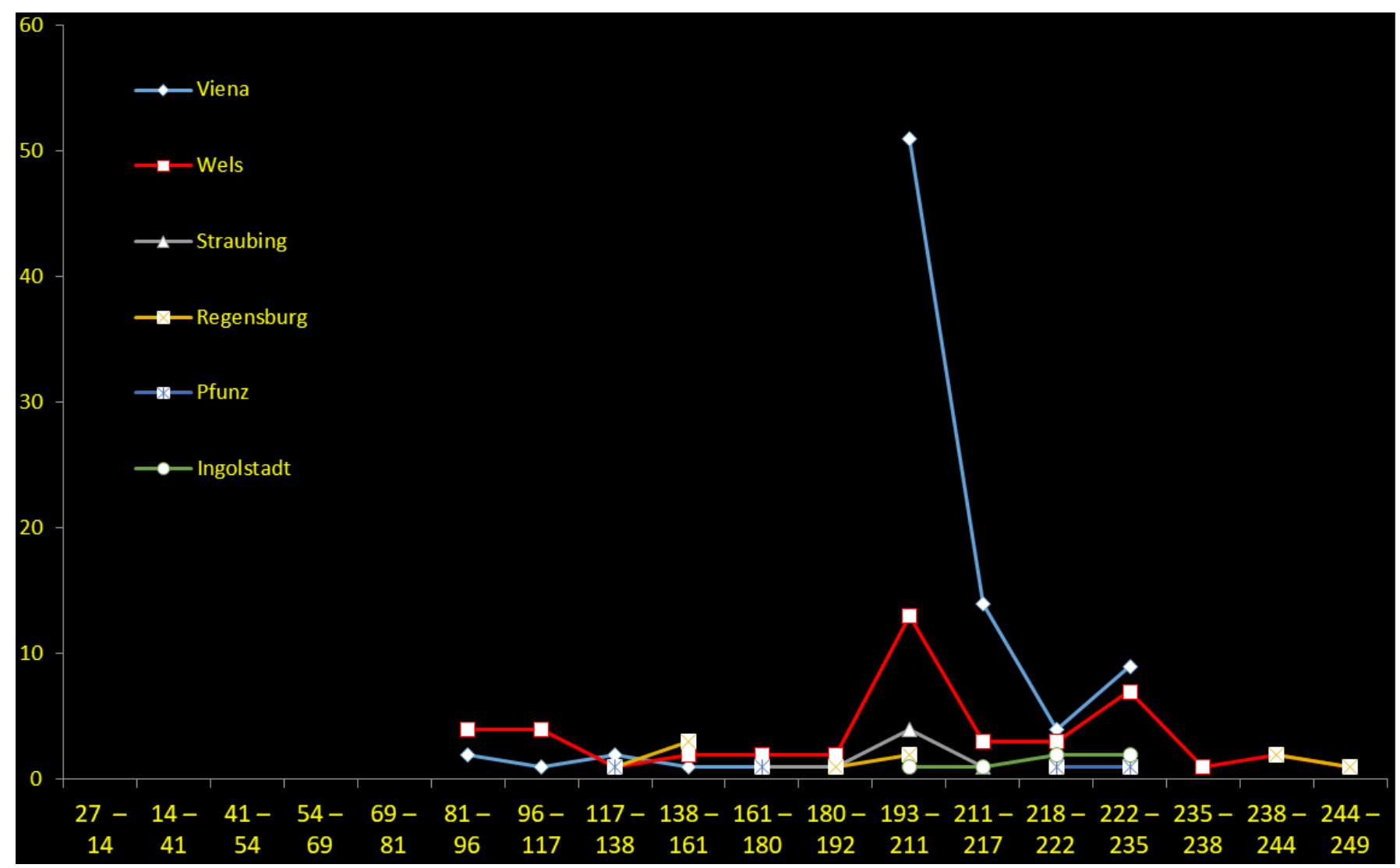

Fig.66. Graph with number of silver coins for Upper Danube region - plated pieces; 
The coefficients for genuine coins is not very high during Nero and the civil war of $69 \mathrm{AD}$ but the coefficients will increase in value during Vespasian (69-79) and Titus (79-81) and decrease during Domitian (81-96). With the reign of Nerva (96-98) and Trajan (98-117) the coefficients will go up again.

During the Antoninian period most sites show a steady rhythm, only at Wels/OIvilava there is a higher value for genuine pieces especially under Antonius Pius (138161). At Commodus (180-192) all index decreases while during Septimius Severus (193-211) all sites show their coin coefficients going up. For Caracalla (211-217) they will decrease in value but go up again under Elagabalus (218222) and Severus Alexander (222-235).

With the beginning of the Military Anarchy during Maximinus Thrax (235-238) all coefficients go down, a few will increase again under Gordian III (238-244).

In the case of plated coins discovered on sites from this area, Fig. 66, we can see that they were dated from Domitian (81-96) to Philip I (244-249).

Also, there are far fewer identified pieces compared to discovered genuine coins from Fig. 65, most plated coins were identified at Wels dated for the reign of Septimius Severus (193-211) and Severus Alexander (222-235) and at Vienna with the image of Septimius Severus (193-211), Caracalla (218-222) and Severus Alexander (222-235).

For a better representation of the general situation on the region Fig. 67 was created, where both the number of genuine and plated coins are showed for a better comparison. Take into consideration that to create the graph all coins from the sites were considered according to issuer that they represent.

Thus, in the case of the 1.104 identified genuine pieces we can see how the dating starts during Nero (54-68) and the civil war of $69 \mathrm{AD}$, the index goes up for Vespasian (69-79) and Titus (79-81) and decreases during Domitian (81-96). During the Antoninian period, the index will remain on a steady rhythm decreasing only at Commodus (180-192) and increasing very much for the Severian dynasty. The highest value will be reached at Septimius Severus (193-211) but at Maximinus Thrax (235-238) the index will decrease very much, increasing just a little for Gordian III (238-244) and Philip I (244-249).

Plated pieces show another situation. First of all, only 159 pieces were identified and the only during the Severian period the coefficient for plated coins will increase in value, especially for Septimius Severus (193-211).

Next studied sites, belonging from Germania Superior, were integrated in the Upper Rhine region, Fig. 68. There are a few sites where there have been discovered coins with images from the first half of the I century but the majority of pieces are dated starting with Nero (54-68) and the civil war of $69 \mathrm{AD}$ or during Vespasian (69-79) and Titus (79-81).

The genuine coin index will remain on a steady course for the time of Domitian (81-96) and Antoninian period, only at Nida and Zugmantel higher coin values being identified. For the period of Commodus (180-192) all index values decrease for all sites but will increase again during the reign of Septimius Severus (193-211), decrease again during Caracalla (211-217) and increase under Elagabalus (218222) and Severus Alexander (222-235), highest values of

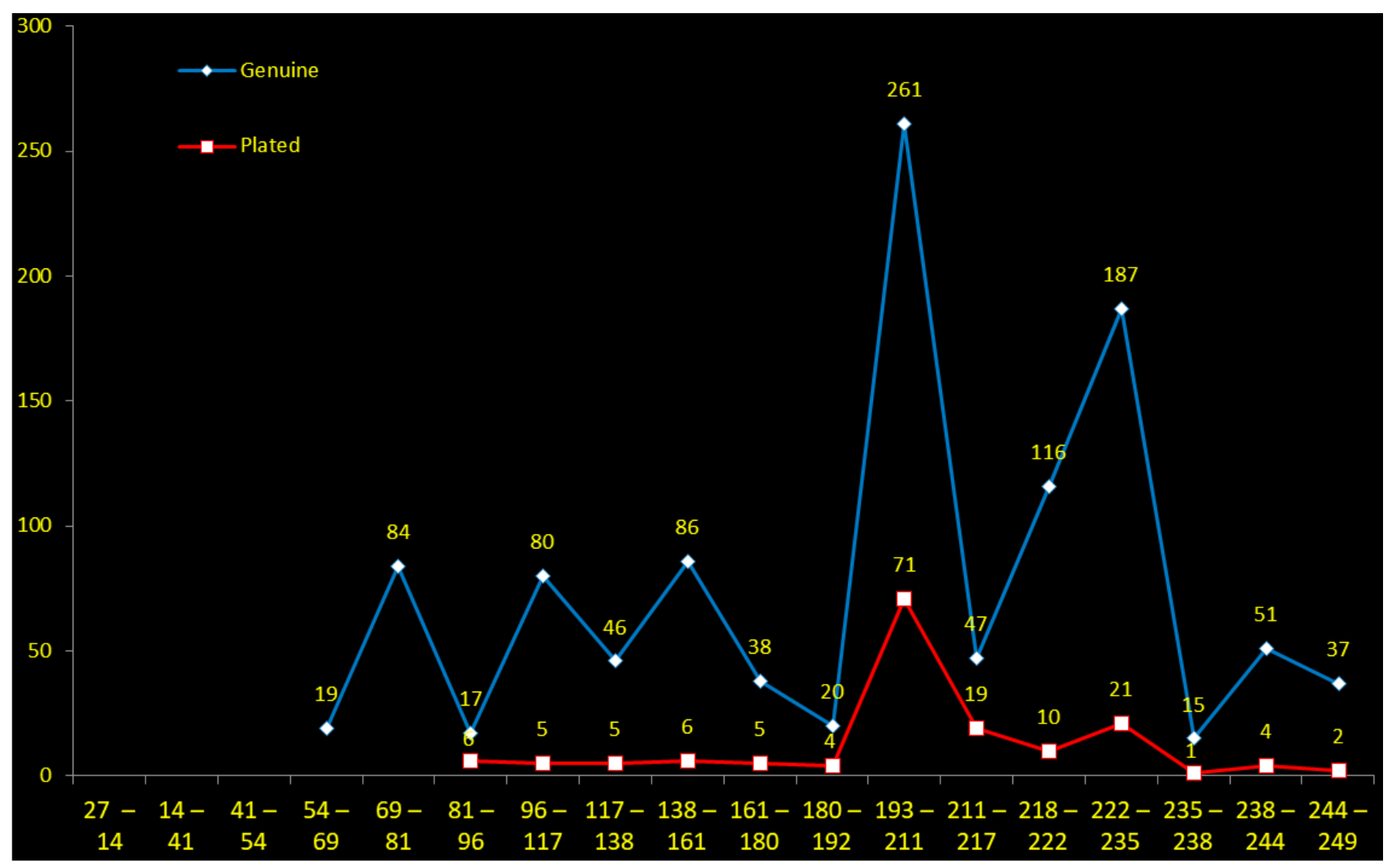

Fig.67. Graph with number of silver coins for Upper Danube region - genuine and plated pieces; 


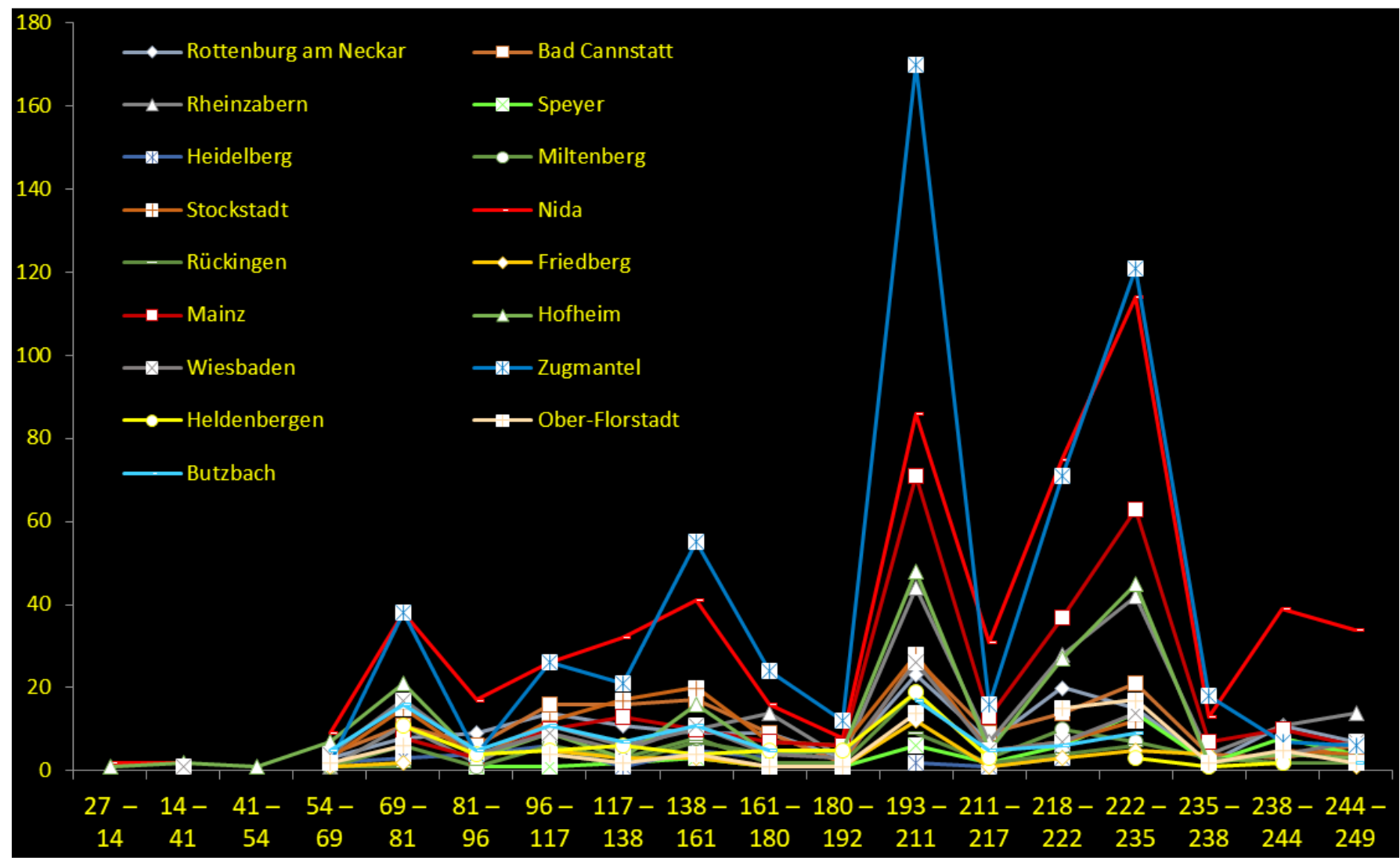

Fig.68. Graph with number of silver coins for Upper Rhine region - genuine pieces;

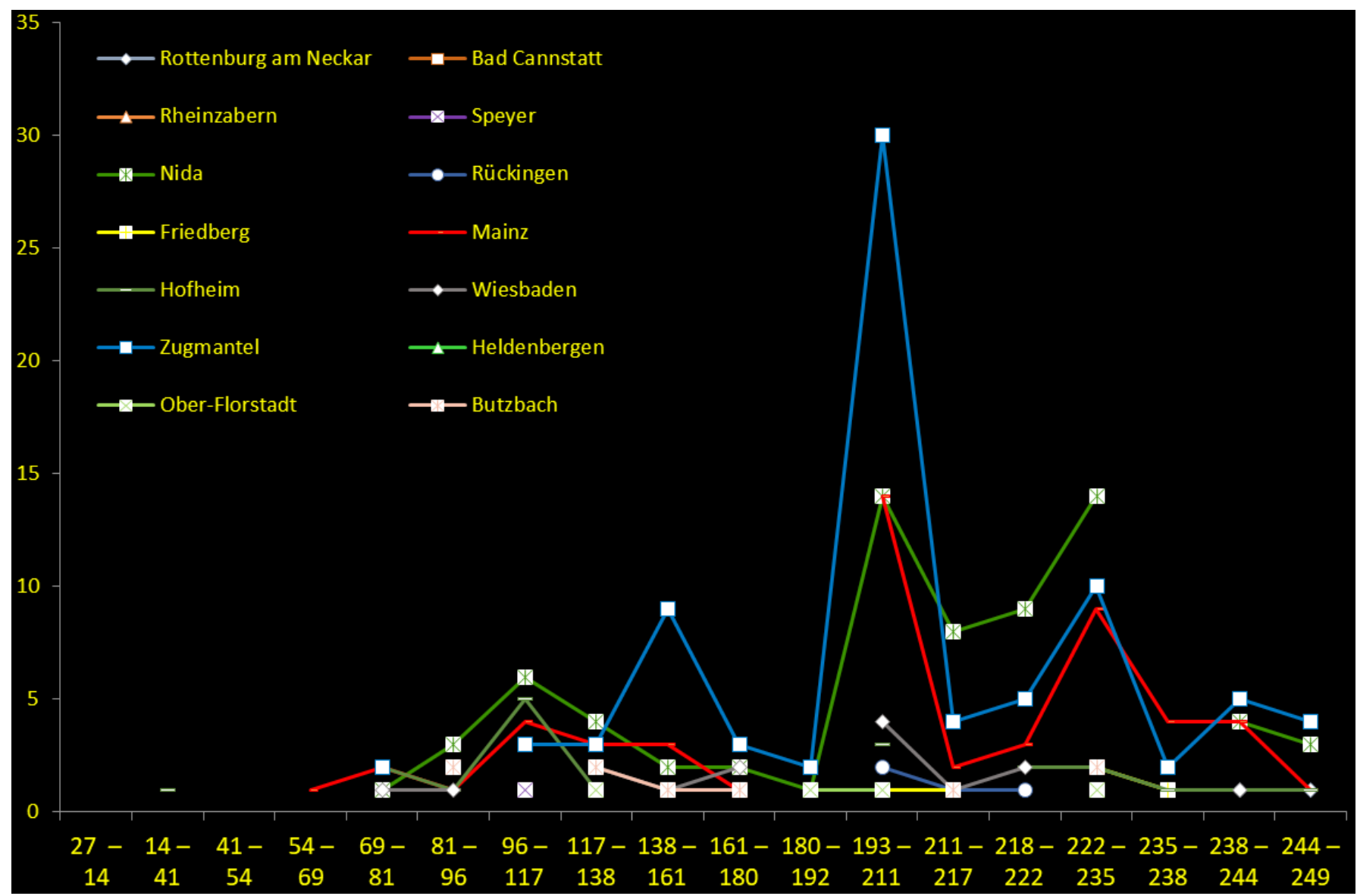

Fig.69. Graph with number of silver coins for Upper Rhine region - plated pieces; 


\section{Studies}

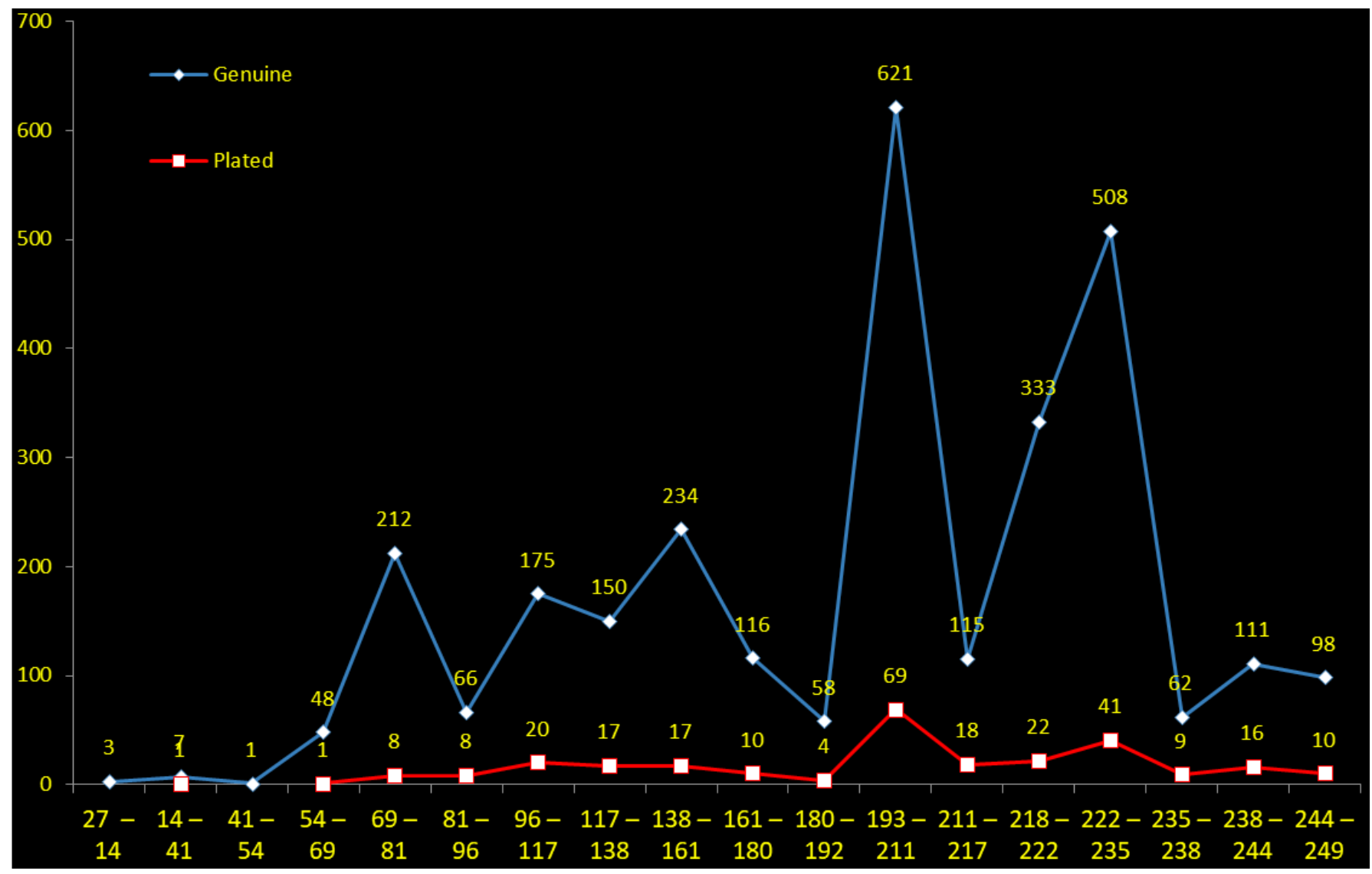

Fig.70. Graph with number of silver coins for Upper Rhine region - genuine and plated pieces;

coins were identified at Nida, Zugmantel and Mainz.

With the beginning of the Military Anarchy the coefficients will decrease, only in the case of Nida the index will increase during the reign of Gordian III (238-244) and Philip I (244-249).

Regarding silver plated coins discovered in this region we have Fig. 69 which shows pieces dated from Nero (5468) to Philip I (244-249), highest values being recorded for Septimius Severus (193-211) and Severus Alexander (222235) at Zugmantel, Nida and Mainz.

In the case of the general situation for Upper Rhine region, Fig. 70, there is a visible difference between genuine and plated pieces. Even if there were some few coins dated at the first half of the I century, the introduction of the silver coins by Roman authorities is better dated at the time of Nero (54-68) and the civil war of 69 AD.

The coefficient for genuine coins will increase during Vespasian (69-79) and Titus (79-81) and decrease for Domitian (81-96), value which increases again and maintain a steady rhythm during the Antoninian period.

For the period of Commodus (180-192) the coin coefficient will decrease, however during Septimius Severus (193-211) the coefficient will go up reaching the highest value for any period, up to two and a half more coins than any previous periods. During Caracalla (211-217) the index will decrease again but increase during Elagabalus (218-222) and Severus Alexander (222-235).

With the beginning of the Military Anarchy the genuine index will decrease in value, a small increase in value is visible for Gordian III (238-244) and Philip I (244-249).
On the other hand, even if the plated pieces were dated from Nero (54-68) to Philip I (244-249), only periods with some significant coins are those for Septimius Severus (193-211) and Severus Alexander (222-235).

Last formed region was that of Lower Rhine, which consists of archaeological sites from Germania Inferior and Gallia Belgica. First graph seen in Fig. 71 represents the distribution of genuine silver pieces according to where the coin was found. We can observe a distribution pattern for the smaller sites, except for bigger ones like Nijmegen and Trier.

In the case of Nijmegen, silver pieces are already present during the reign of Augustus (27BC-14AD) while during the reign of Hadrian (117-138) the military troops were transferred from this place and the coin infusion in the area was drastically affected. Most of the genuine pieces were dated during the $69 \mathrm{AD}$ civil war and to its victors, Vespasian (69-79) and his sons Titus (79-81) and Domitian (81-96).

Trier was located at some distance from the Roman frontier and was a civilian economic center in the area, therefor the coin infusion is different than that of a military fort. It is easy to observe how the coefficient for genuine pieces begins during the I century $\mathrm{AD}$, it increases in value during the reign of Nero (54-68) and the civil war of 69 AD, it keeps increases for Vespasian (69-79) and Titus (79-81). For the reign of Domitian (81-96) the coin index will decrease but increase again during Trajan (98-117) and Hadrian (117138) followed by a decrease in value for Antonius Pius (138161), Marcus Aurelius (161-180) and Commodus (180-192). During Septimius Severus (193-211) the coin index 


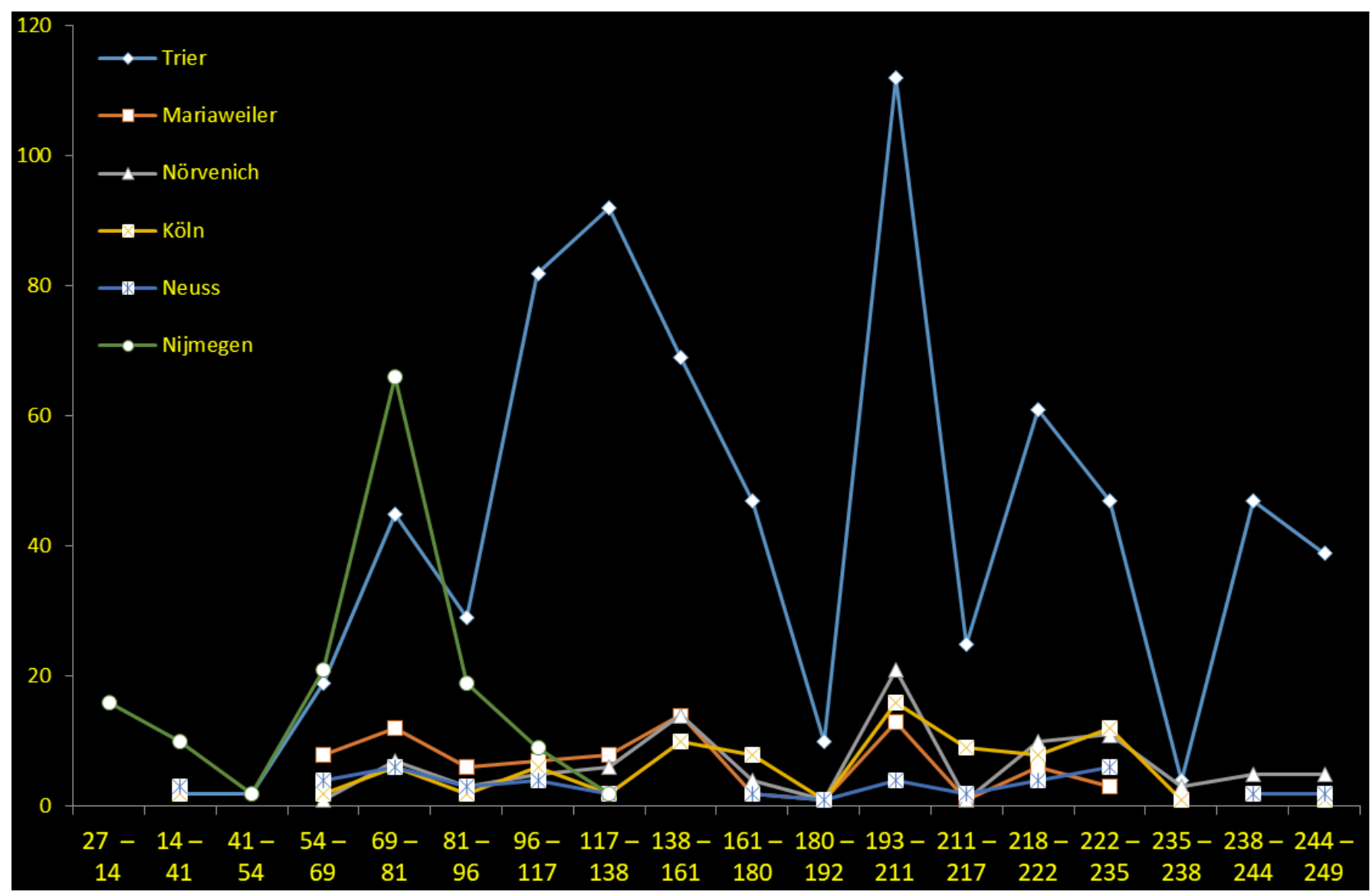

Fig.71. Graph with number of silver coins for Lower Rhine region - genuine pieces;

will increase reaching the highest values, followed by a decrease during Caracalla (211-217) another increase at Elagabalus (218-222) and a decrease at Severus Alexander (222-235) and Maximinus Thrax (235-238). With the beginning of Military Anarchy period a new increase in the value of the genuine coins is observed.

Regarding the other sites, discovered silver coins show a continuous supply of pieces dated from Nero (54-68) and until the beginning of Military Anarchy, highest values being recorded for Antonius Pius (138-161) and Septimius Severus (193-211).

Next graph represented in Fig. 72 shows all plated pieces discovered in this region. Unfortunately, because of the small number of identified coins no real historical information can be learned from this graph which looks more as a "modern art" piece that a graph for coin distribution.

In the case of Lower Rhine region and the total number of genuine pieces discovered on Roman sites we have Fig. 73 which shows two different situations.

First of them, seen using white-blue colors and having higher coin values represents the total number of genuine silver coins from Lower Rhine region including Trier, Fig. 54. The presence of coins starts at Augustus (27BC-14AD) than continues for Tiberius (14-37) and Caligula (37-41), but the coin coefficient will decrease for the period of Claudius (4154).

During Nero (54-68) and the civil war of 69 the coin index will increase and keep increasing in value during Vespasian (69-79) and Titus (79-81), follows a decrease for Domitian (81-96) and a new increase and steady rhythm for Trajan (98-117), Hadrian (117-138) and Antoninius Pius (138-161). For Marcus Aurelius (161-180) and during Commodus (180-192) the index will decrease again reaching very low values.

With the beginning of the Severian dynasty the index will rise again in value under Septimius Severus (193-211) and decrease at Caracalla (211-217), while for Elagabalus (218-222) and Severus Alexander (222-235) it will increase again in value.

During the reign of Maximinus Thrax (235-238) the coin index is represented by very low values but the situation will change during Gordian III (238-244) and Philip I (244249) when the index increases in value.

The second situation represented with red-blue shows the total number of genuine silver coins from Lower Rhine region without the pieces from Trier. As seen in Fig. 71, we can easily observe the pattern followed by genuine pieces. Only the site from Nijmegen has a visible impact on the graph because of high number of dated pieces during the I century $\mathrm{AD}$, same time frame with the prosperity of the settlement.

It's easy to see the impact produced by the silver coins discovered at Augusta Treverorum presented in Fig. 73 and the general situation on the region.

The very high number of genuine coins and their distribution differs very much when put together with other studied places because this location was a civilian settlement from the start, an economic and trade hub in the region. Therefor it was supplied round the clock with capital from various sources not like Roman forts situated at the edge 


\section{Studies}

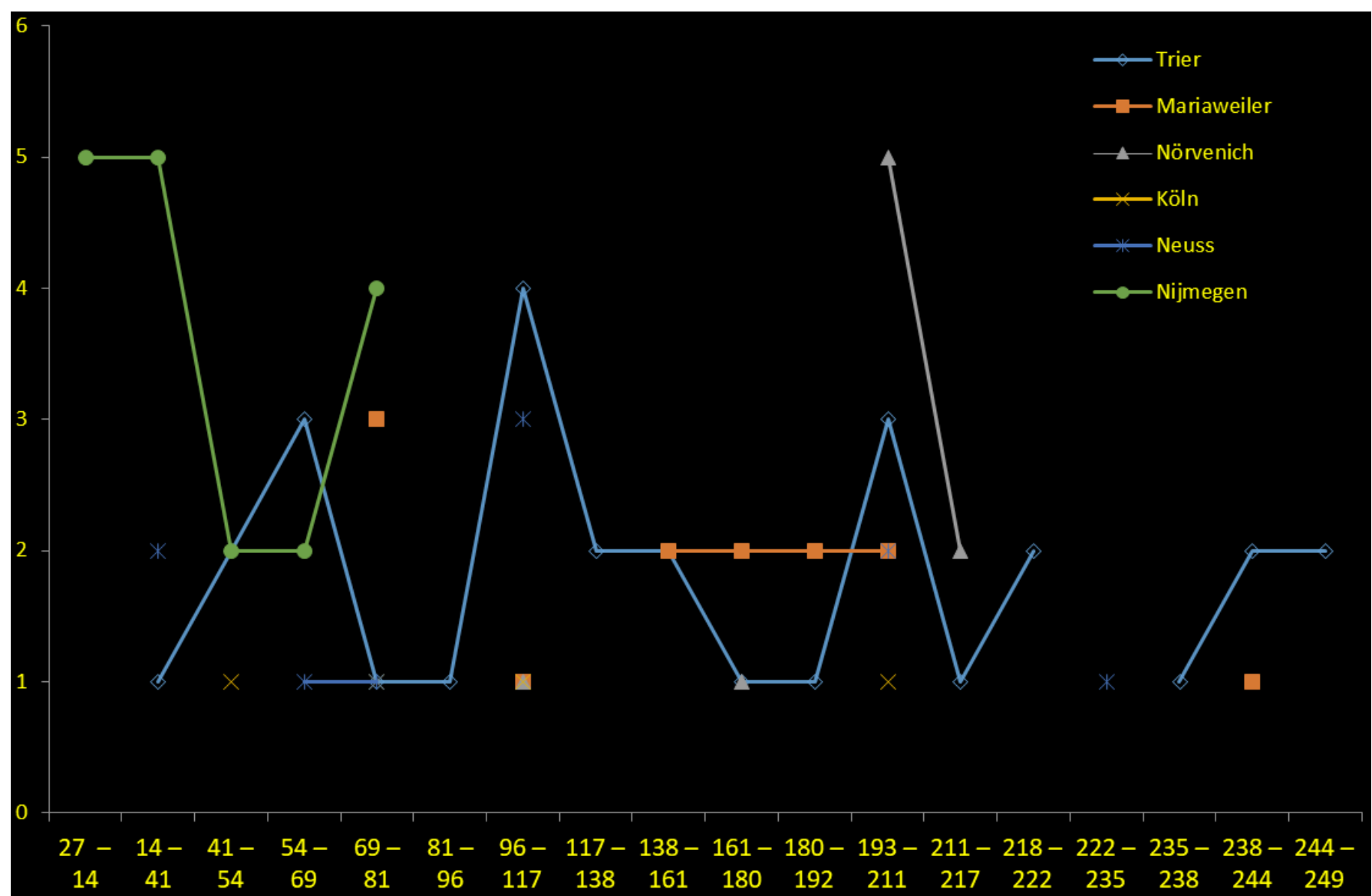

Fig.72. Graph with number of silver coins for Lower Rhine region - plated pieces;

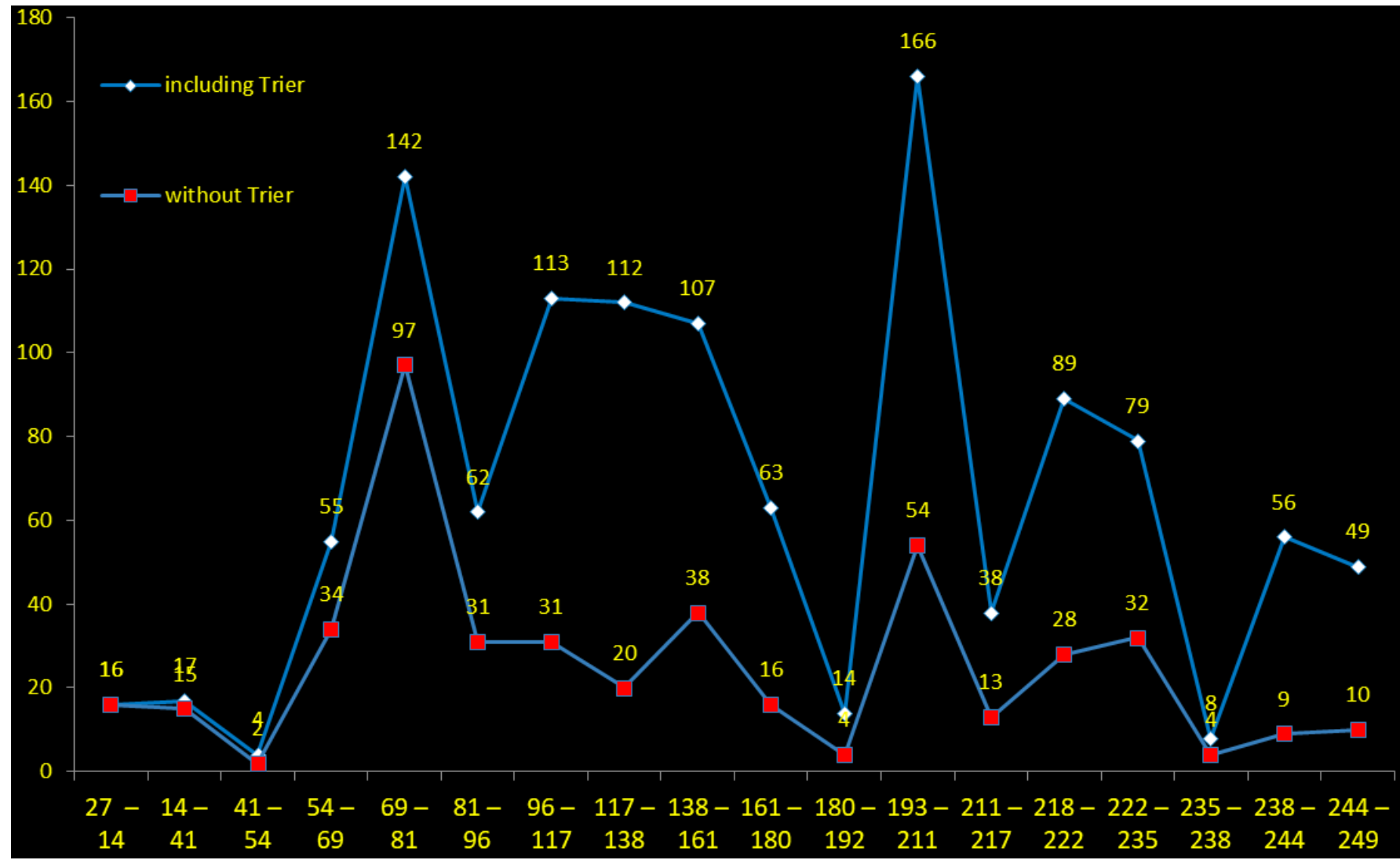

Fig.73. Graph with number of silver coins for Lower Rhine region - genuine pieces; 
of the empire and received their payments at regular time frames.

\section{PLATED COINS DURING SEVERIAN DYNASTY - CASE STUDY}

After looking at all graphs made until now a common image is always present, the very high number of pieces dated for Severian dynasty. Thus, for a deeper interpretation a few sites were selected from the current regions of Upper Danube, Lower and Upper Rhine and were compared with sites from Middle Danube, more exactly Pannonia and Dacia.

In order to produce accurate information only sites where large quantities of coin were identified have been chosen for this case study. The following pie charts show the number of genuine and plated coins and the proportion of them on the site.

\section{Vienna - Vindobona (Austria)}

First comes the regions of Upper Danube, Upper and Lower Rhine with the site of Vindobona ${ }^{140}$ seen in Fig. 74

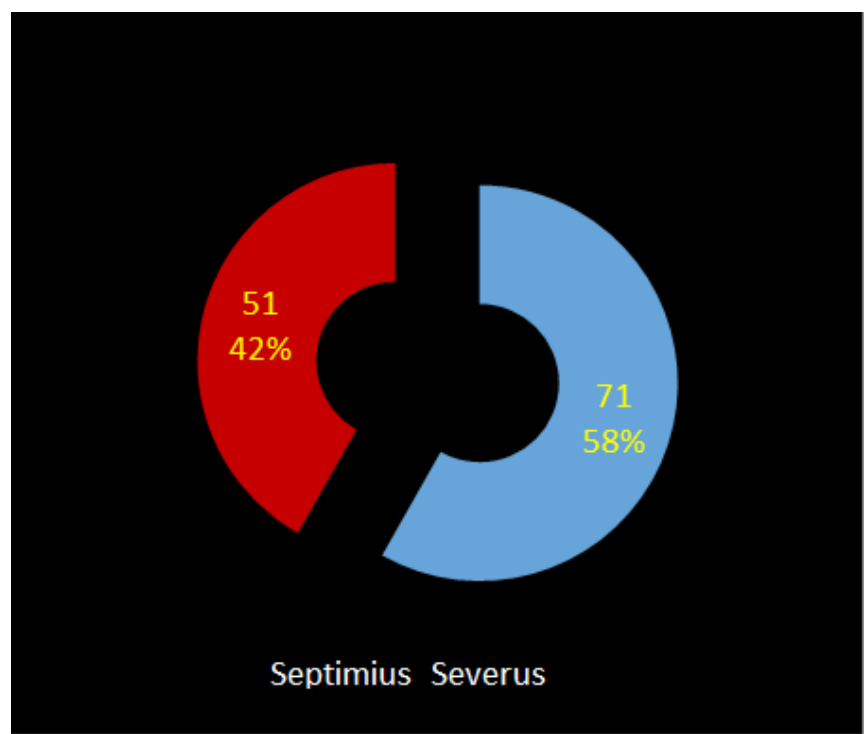

Fig. 74

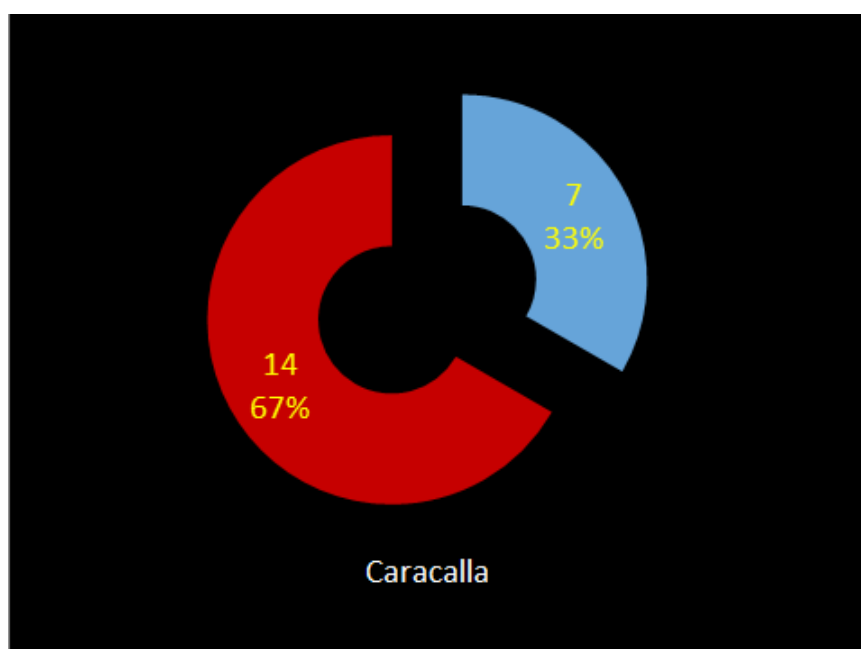

Fig. 75

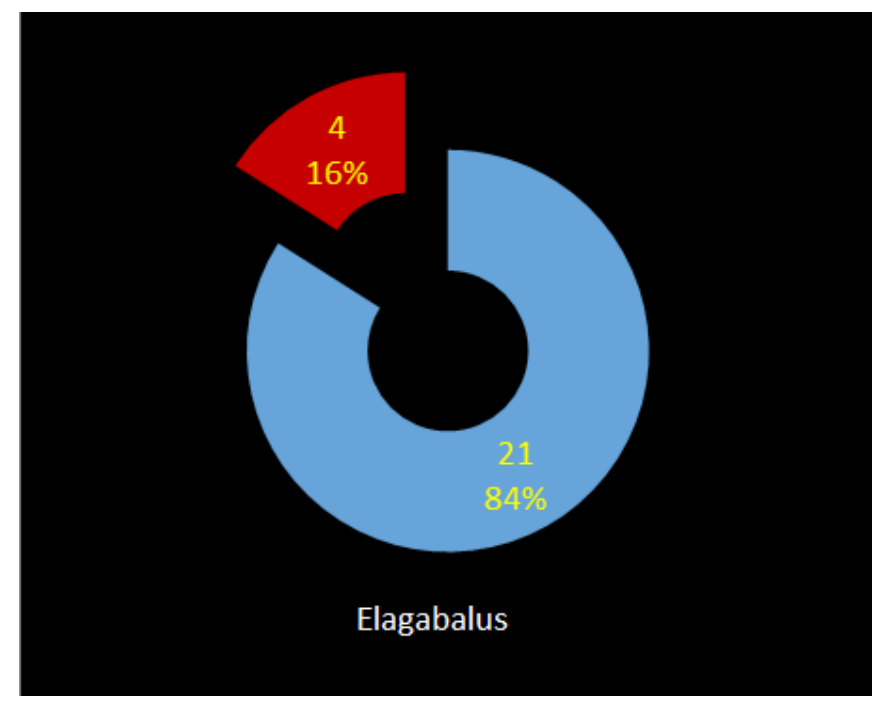

Fig. 76

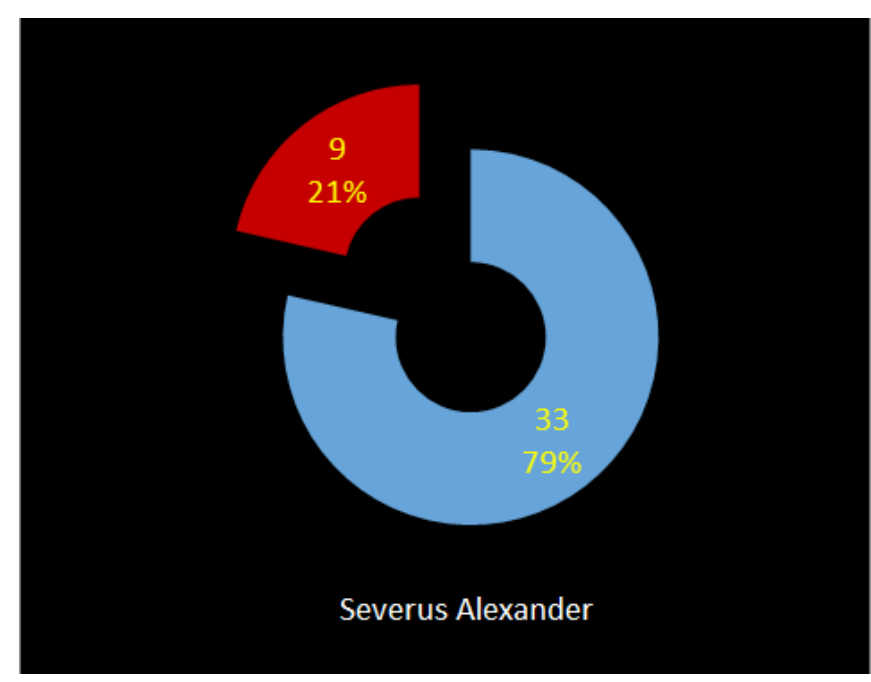

Fig. 77

regarding the reign of Septimius Severus (193-211) with a proportion of $58 \%$ genuine pieces, 71 coins, and $42 \%$ plated pieces, 51 coins. Fig. 55 regarding the reign of Caracalla (211217 ) with a proportion of $33 \%$ genuine pieces, seven coins, and $67 \%$ plated pieces, 14 coins. Fig. 76 regarding the reign of Elagabalus (218-222) with a proportion of $84 \%$ genuine pieces, 16 coins, and 21\% plated pieces, four coins. Fig 77 regarding the reign of Severus Alexander (222-235) with a proportion of $79 \%$ genuine pieces, 21 coins, and 33\% plated pieces, nine coins.

\section{Wels - Ovilava (Austria)}

For the site of Ovilava ${ }^{141}$ we have Fig. 78 for pieces dated during Septimius Severus (193-211), 81\% are genuine, 57 pieces, while $19 \%$ are plated, 13 pieces. Fig 79 shows dated pieces during the reign of Caracalla (211-217), 85\% are genuine, 17 coins, $15 \%$ are plated, three coins. Fig. 80 for pieces dated during Elagabalus (218-222), 90\% are genuine, 26 coins, while $10 \%$ are plated, three coins. Fig. 81 for pieces dated during Severus Alexander (222-235), 90\% are genuine, 60 coins, while $10 \%$ are plated, seven coins. 


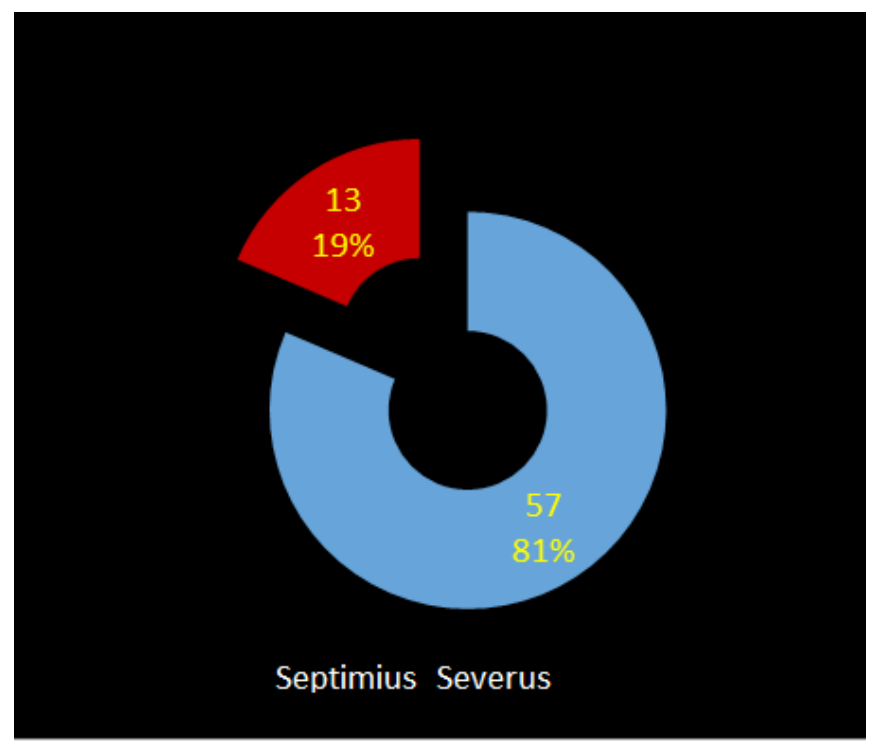

Fig. 78

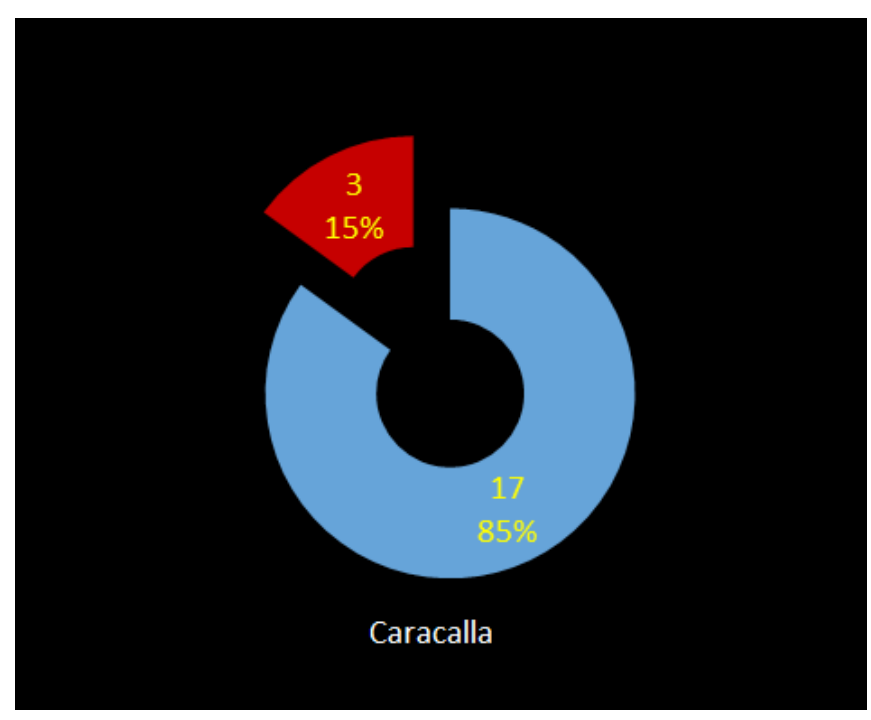

Fig. 79

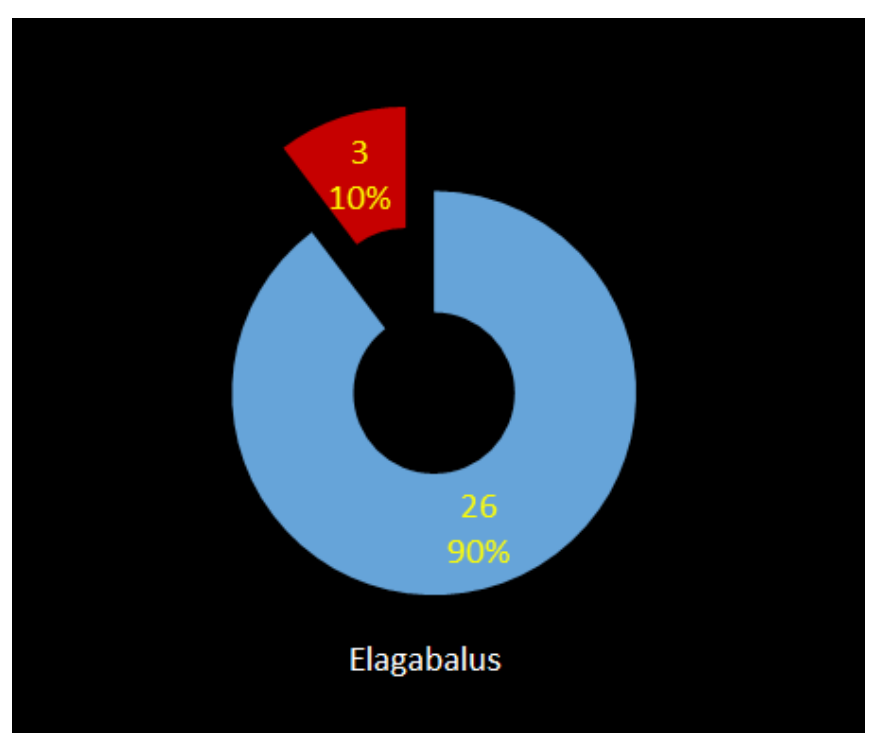

Fig. 80

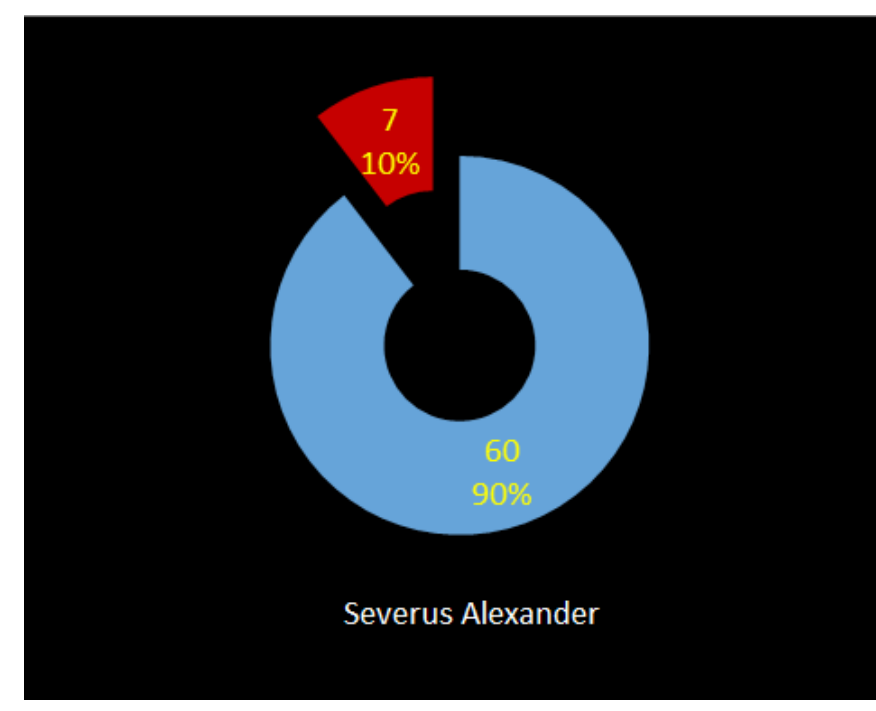

Fig. 81

Regensburg - Castra Regina (Germany)

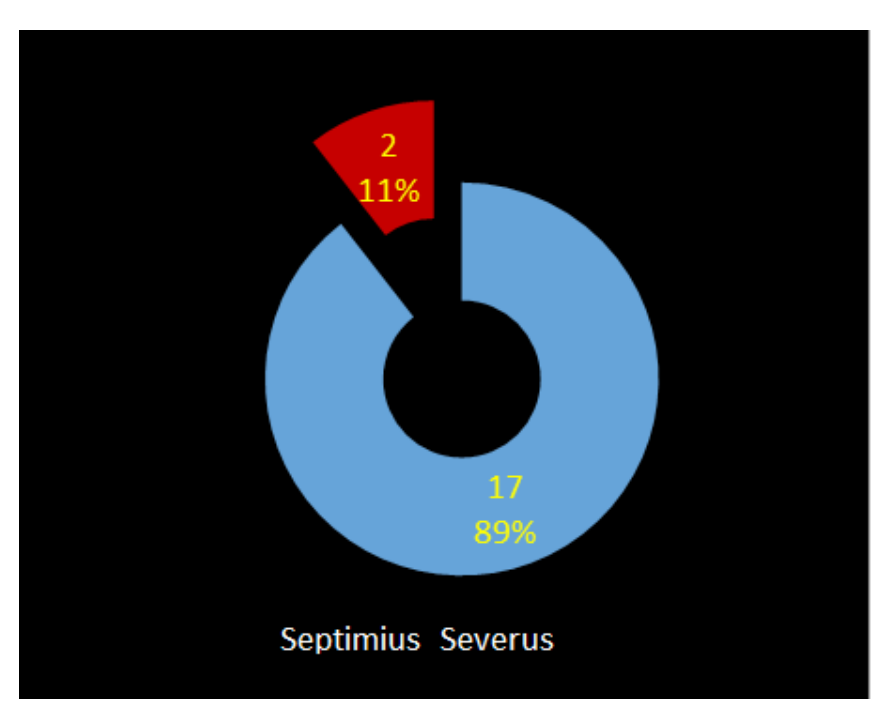

Fig. 82

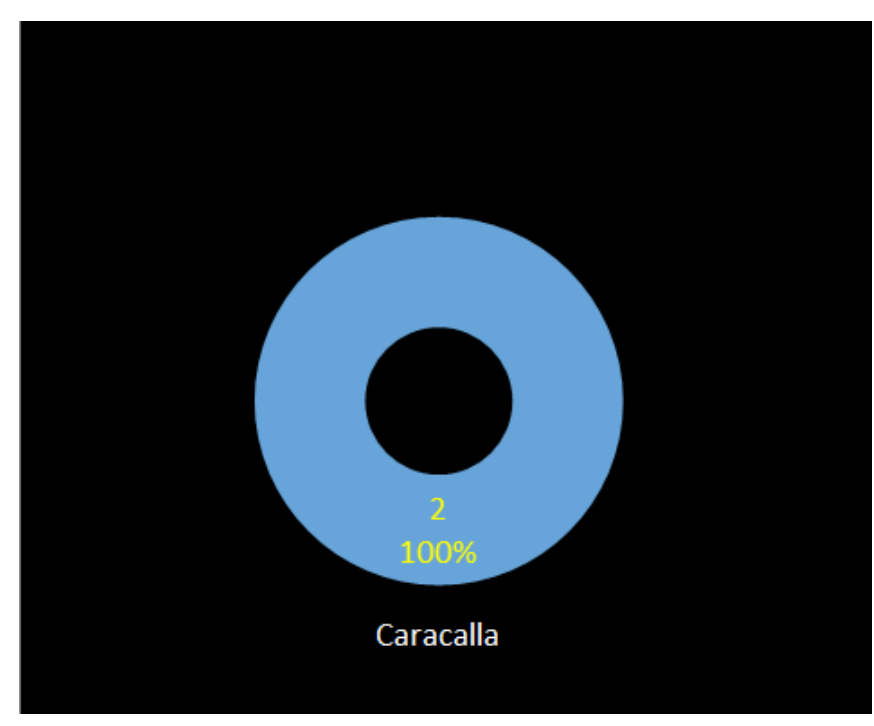

Fig. 83 


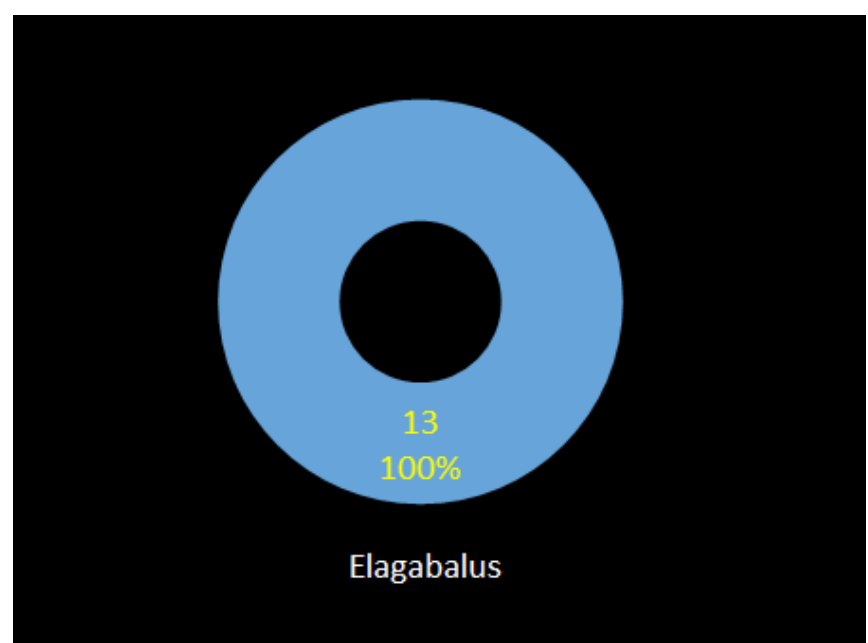

Fig. 84

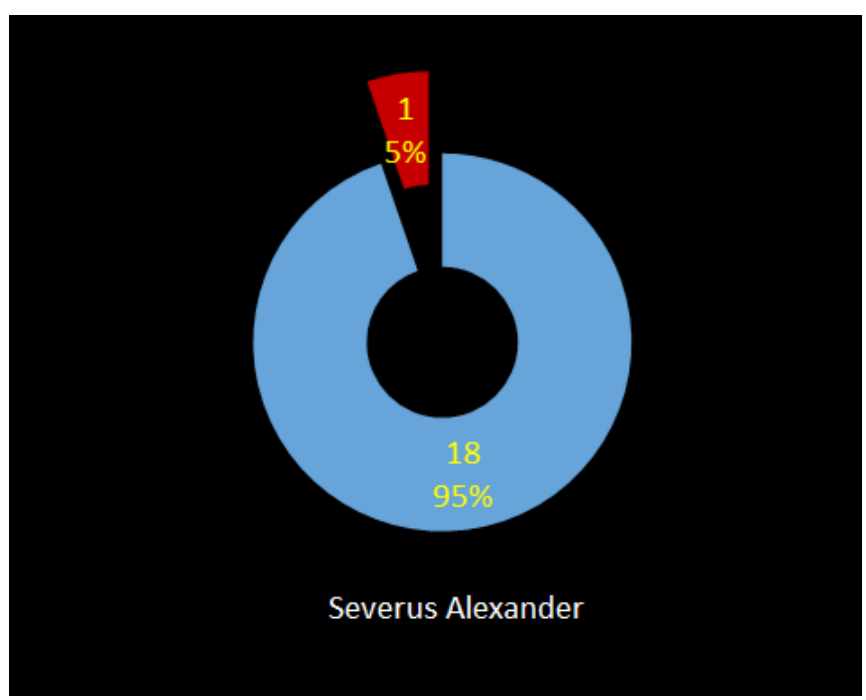

Fig. 85

Castra Regina ${ }^{142}$ seen in Fig. 82 regarding the reign of Septimius Severus (193-211) with a proportion of $89 \%$ genuine pieces, 17 coins, and $11 \%$ plated pieces, two coins. Fig. 83 regarding the reign of Caracalla (211-217) with a proportion of $100 \%$ genuine pieces, two coins. Fig. 84 regarding the reign of Elagabalus (218-222) with a proportion of $100 \%$ genuine pieces, 13 coins. Fig 85 regarding the reign of Severus Alexander (222-235) with a proportion of $95 \%$ genuine pieces, 18 coins, and $5 \%$ plated pieces, one coin.

\section{Eining (Germany)}

For the site of Eining ${ }^{143}$ we have Fig. 86 for pieces dated during Septimius Severus (193-211), 89\% are genuine, 33 pieces, while $11 \%$ are plated, four pieces. Fig 87 shows dated pieces during the reign of Caracalla (211-217), 92\% are genuine, 11 coins, $8 \%$ are plated, one coin. Fig. 88 for pieces dated during Elagabalus (218-222), 100\% are genuine, 31 coins. Fig. 89 for pieces dated during Severus Alexander (222-235), 100\% are genuine, 40 coins.

\footnotetext{
$142 \quad$ FMRD 1978, 51.

143 FMRD 1970.
}

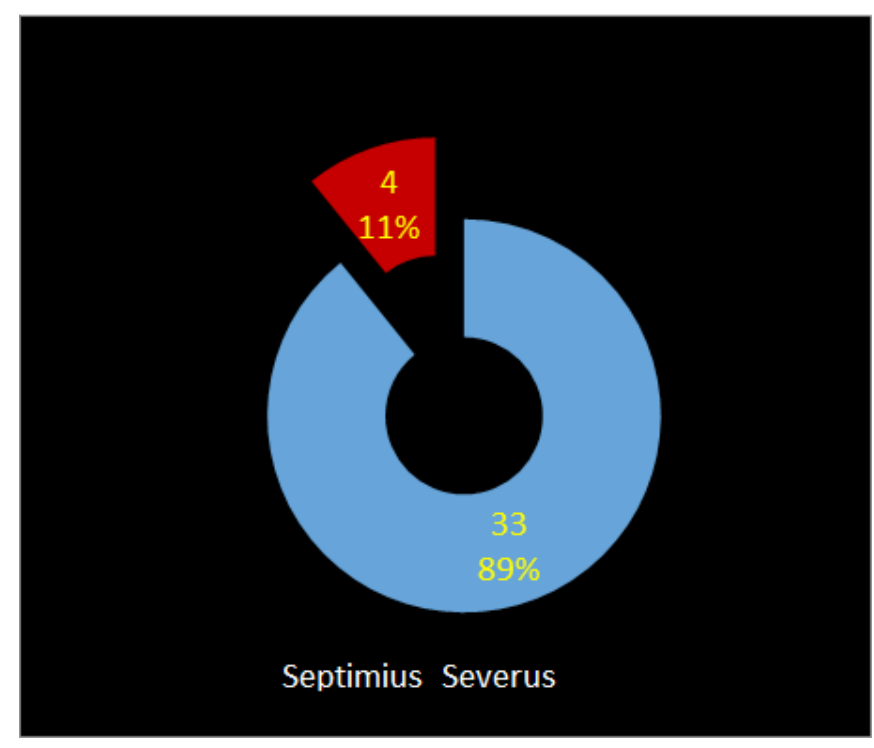

Fig. 86

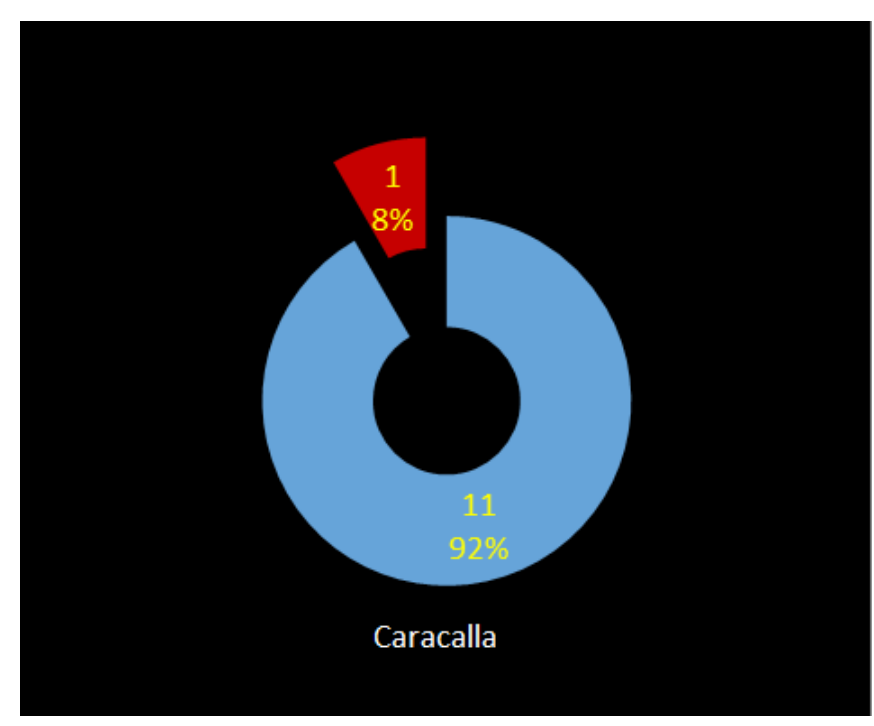

Fig. 87

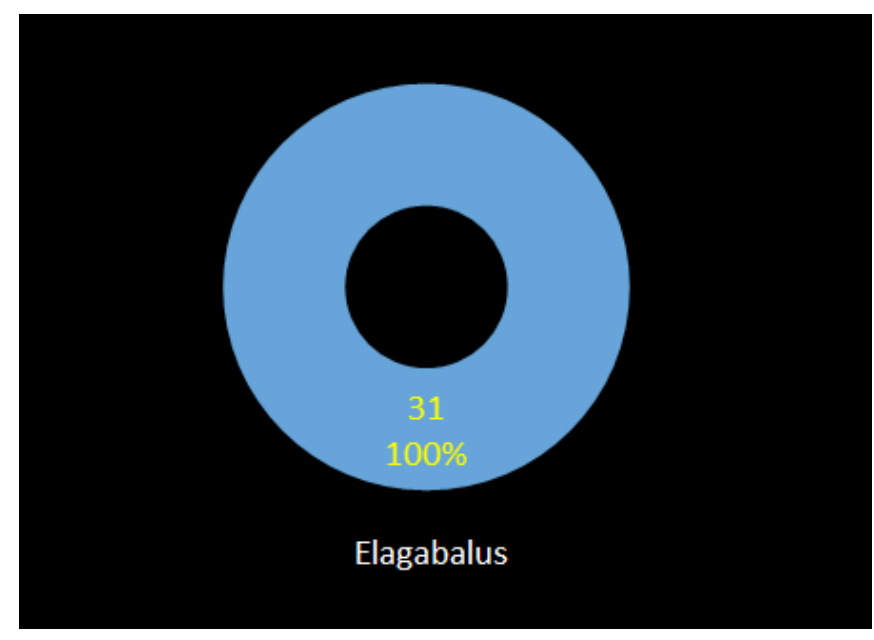

Fig. 88 


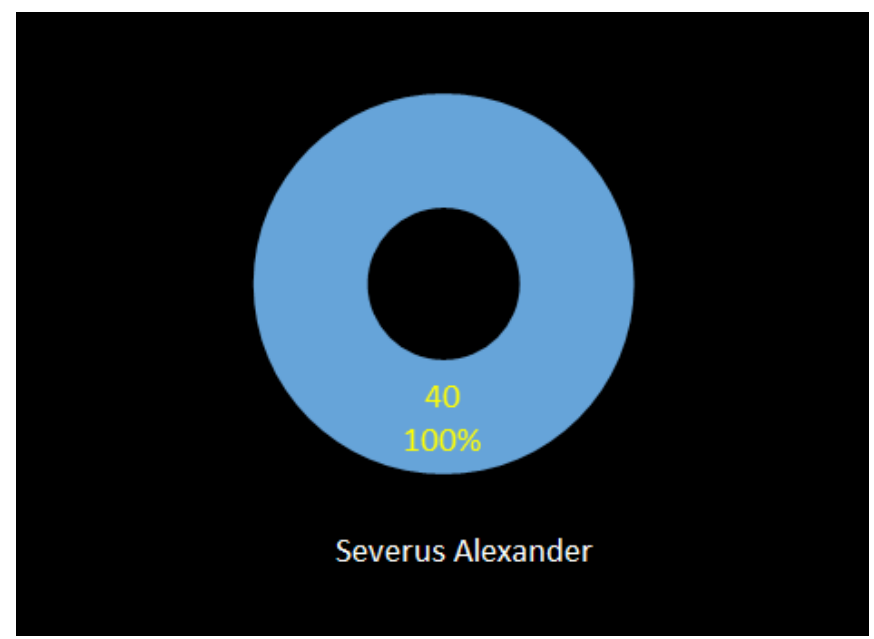

Fig. 89

\section{Augsburg - Augusta Vindelicorum (Germany)}

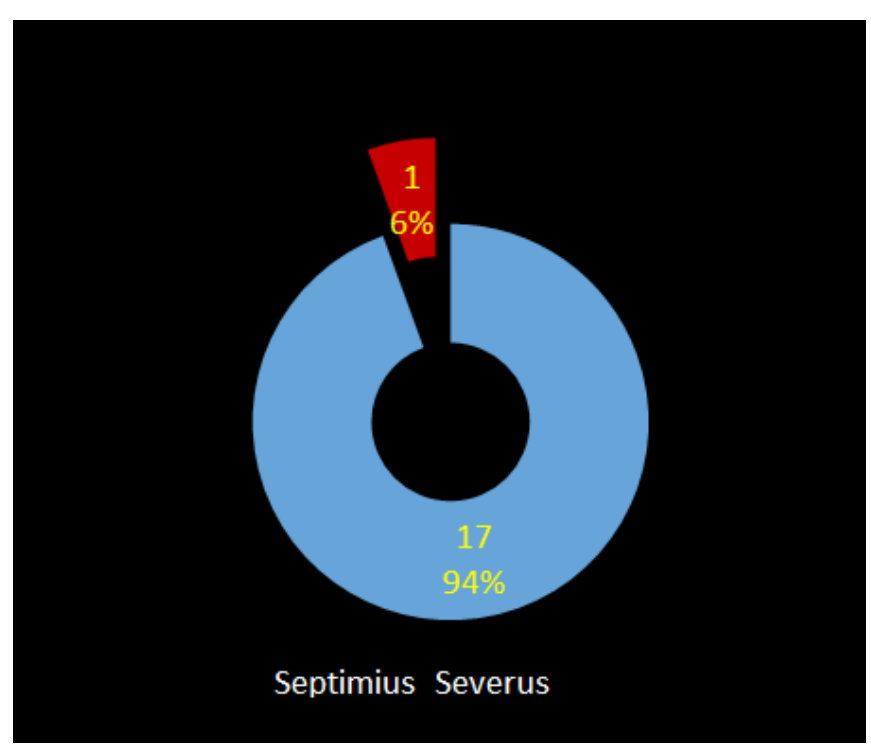

Fig. 90

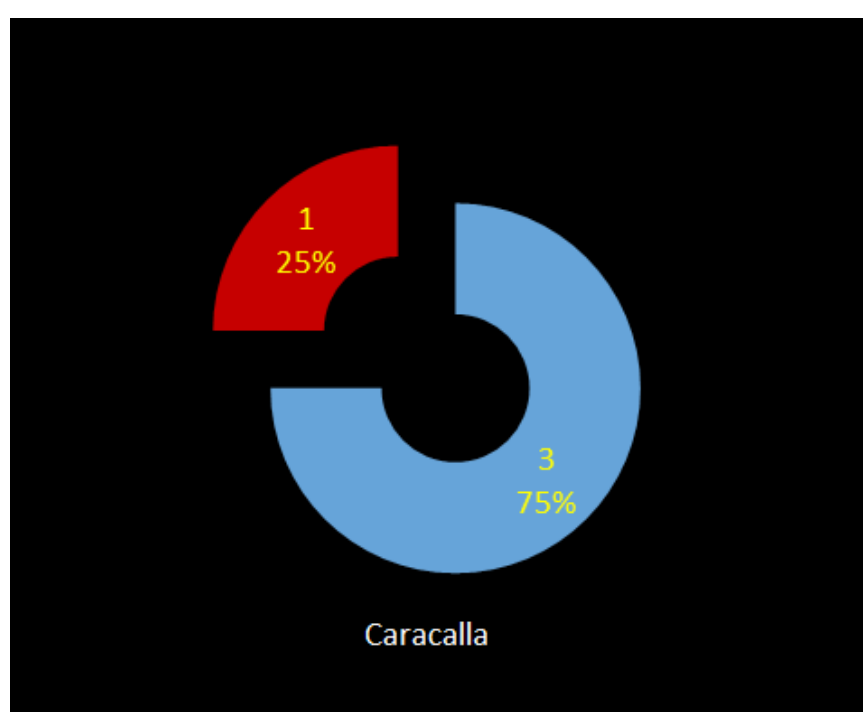

Fig. 91

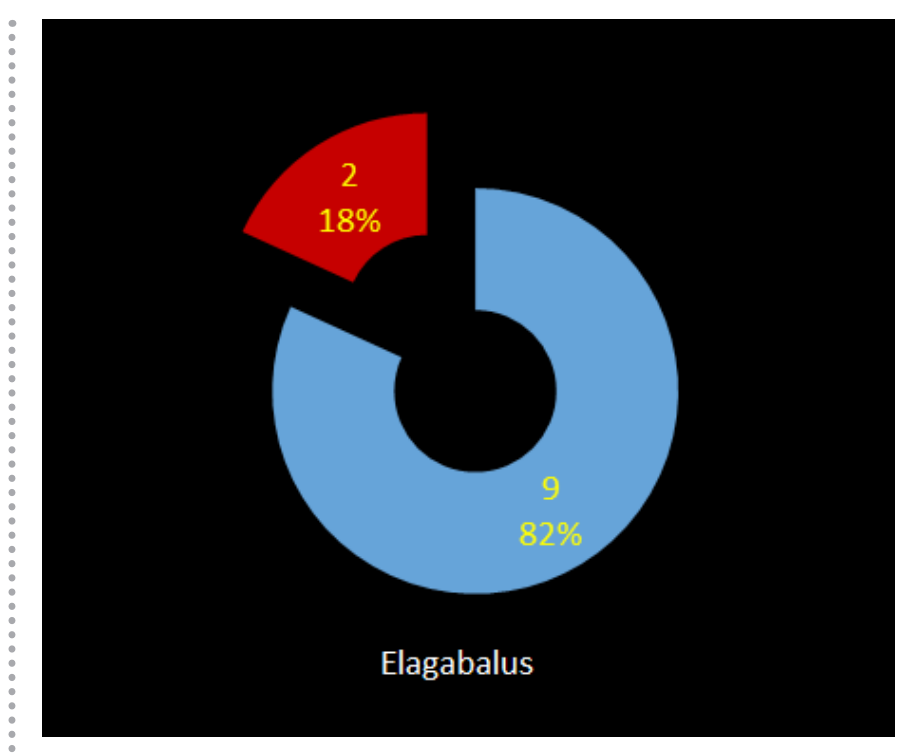

Fig. 92

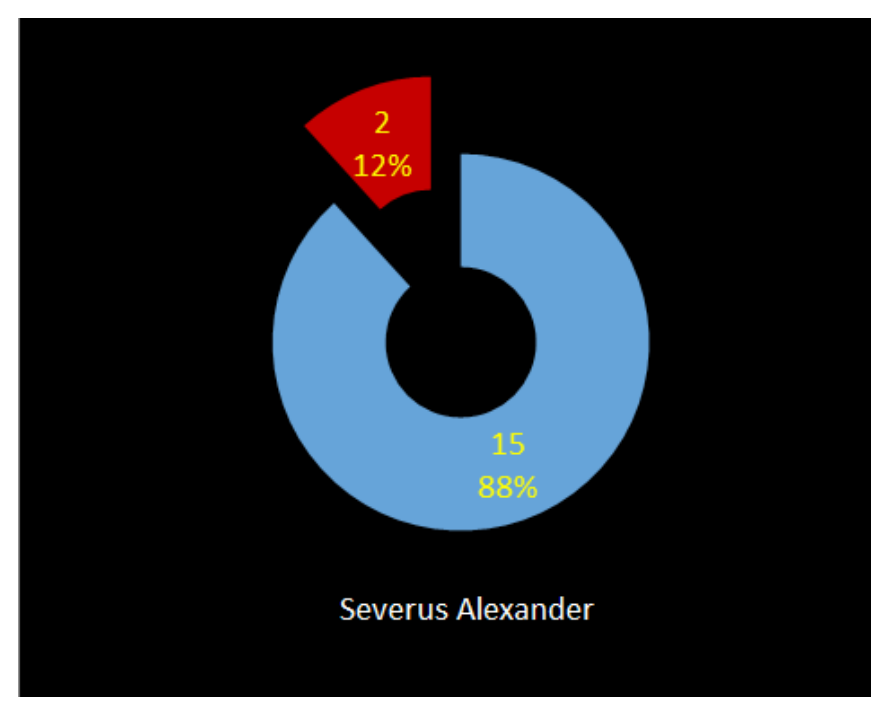

Fig. 93

Augusta Vindelicorum ${ }^{144}$ seen in Fig. 90 regarding the reign of Septimius Severus (193-211) with a proportion of $94 \%$ genuine pieces, 17 coins, and $6 \%$ plated pieces, one coin. Fig. 91 regarding the reign of Caracalla (211-217) with a proportion of $75 \%$ genuine pieces, three coins, and $25 \%$ plated pieces, one coin. Fig. 92 regarding the reign of Elagabalus (218-222) with a proportion of $82 \%$ genuine pieces, nine coins, and $18 \%$ plated pieces, two coins. Fig 93 regarding the reign of Severus Alexander (222-235) with a proportion of $88 \%$ genuine pieces, 15 coins, and $12 \%$ plated pieces, two coins.

\section{Nida (Germany)}

For the site of $\mathrm{Nida}^{145}$ we have Fig. 94 for pieces dated during Septimius Severus (193-211), 87\% are genuine, 86 pieces, while $13 \%$ are plated, 13 pieces. Fig 95 shows dated pieces during the reign of Caracalla (211-217), 79\% are genuine, 31 coins, $21 \%$ are plated, eight coins. Fig. 96 for pieces dated during Elagabalus (218-222), 97\% are genuine, 144 FMRD 1962, 31.

145 FMRD 1989b. 


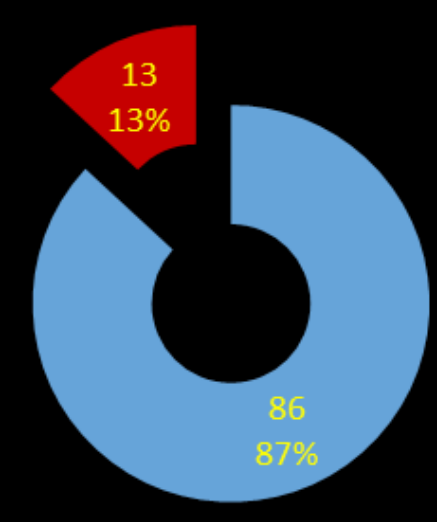

Septimius Severus

Fig. 94

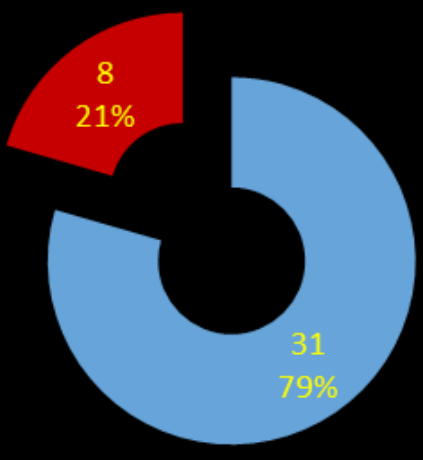

Caracalla

Fig. 95

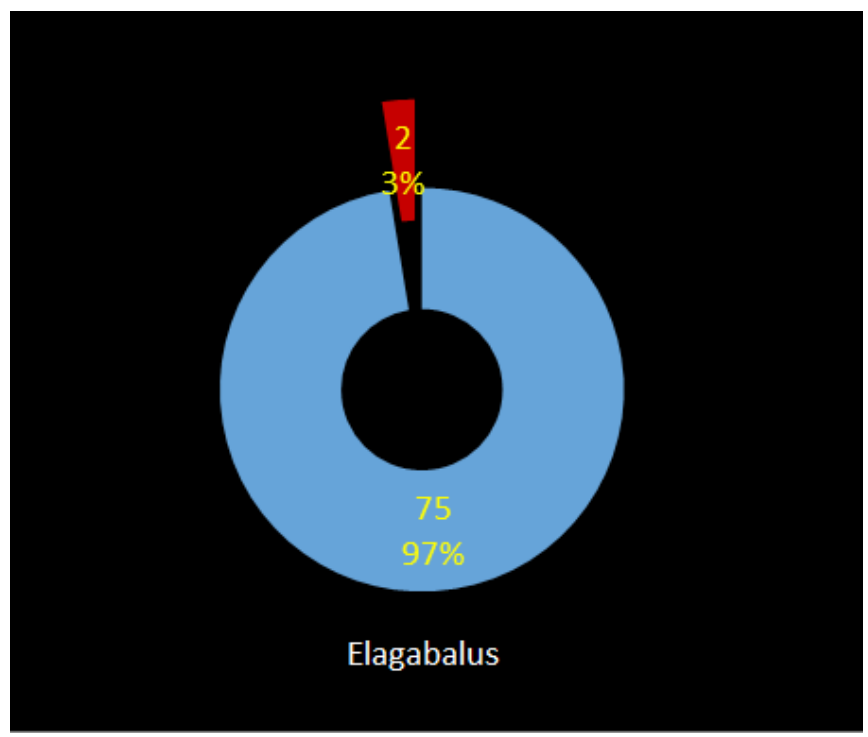

Fig. 96

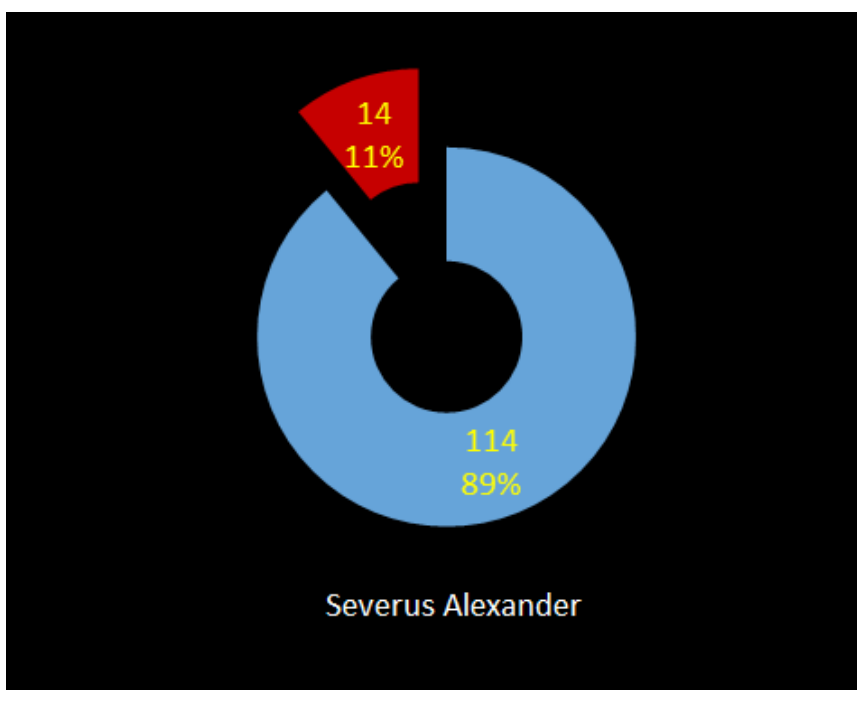

Fig. 97

75 coins, while $3 \%$ are plated, two coins. Fig. 97 for pieces dated during Severus Alexander (222-235), 89\% are genuine, 114 coins, while $11 \%$ are plated, 14 coins.

\section{Mainz - Mogontiacum (Germany)}

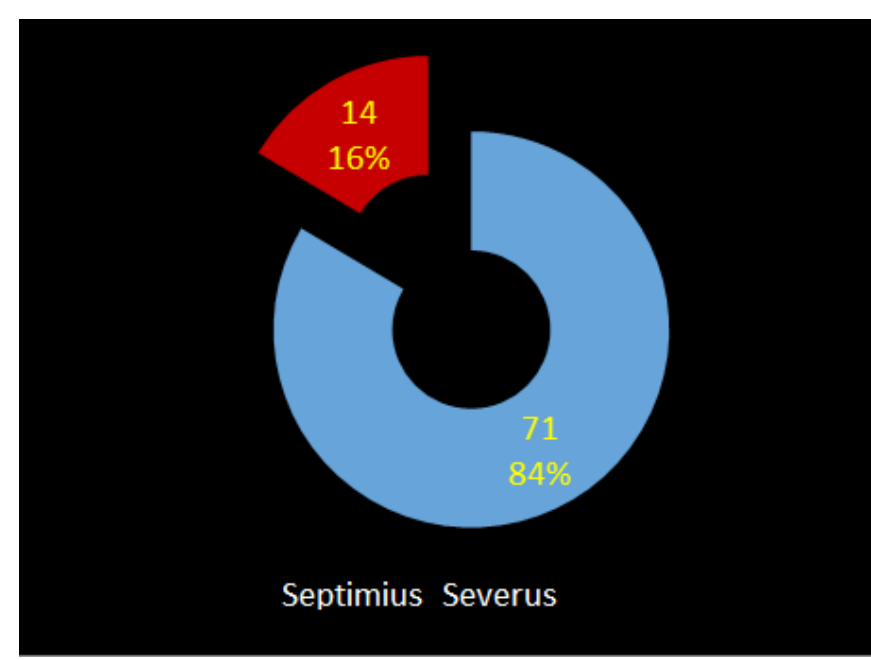

Fig. 98

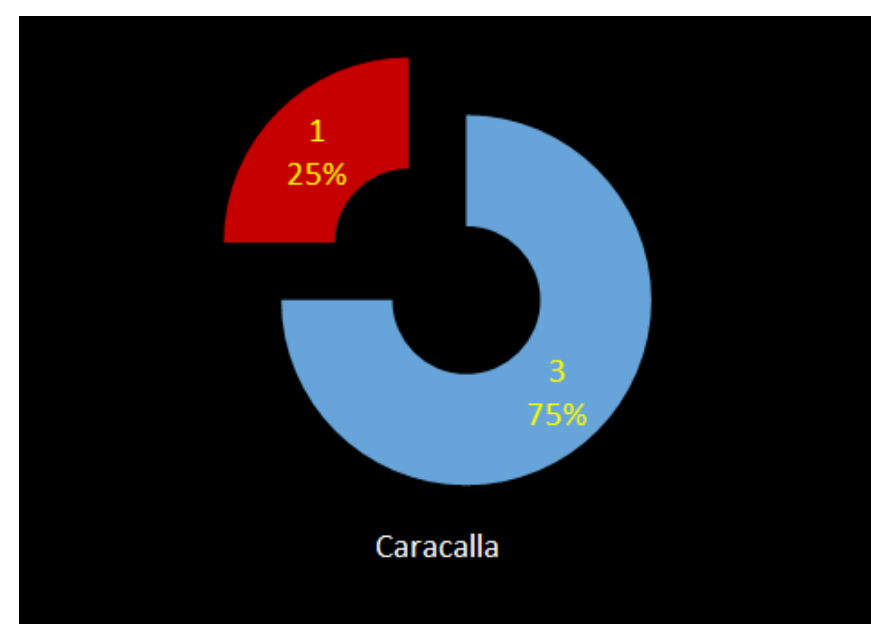

Fig. 99 


\section{Studies}

Mogontiacum ${ }^{146}$ seen in Fig. 98 regarding the reign of Septimius Severus (193-211) with a proportion of $84 \%$ genuine pieces, 71 coins, and 16\% plated pieces, 14 coins. Fig. 99 regarding the reign of Caracalla (211-217) with a proportion of $75 \%$ genuine pieces, three coins, and $25 \%$ plated pieces, one coin. Fig. 100 regarding the reign of Elagabalus (218-222) with a proportion of $92 \%$ genuine pieces, 37 coins, and 8\% plated pieces, three coins. Fig 101 regarding the reign of Severus Alexander (222-235) with a proportion of $87 \%$ genuine pieces, 63 coins, and $13 \%$ plated pieces, nine coins.

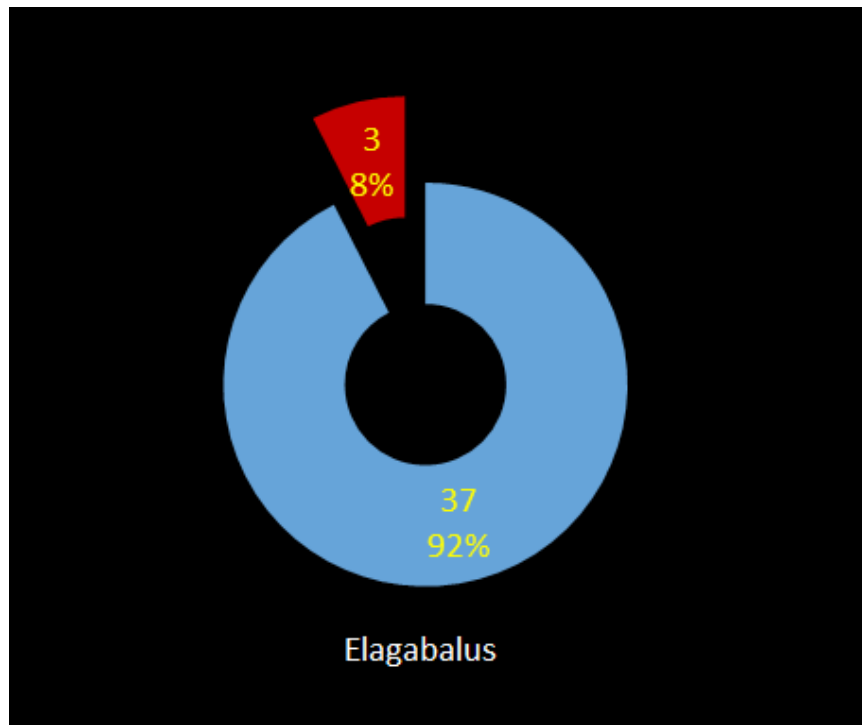

Fig. 100

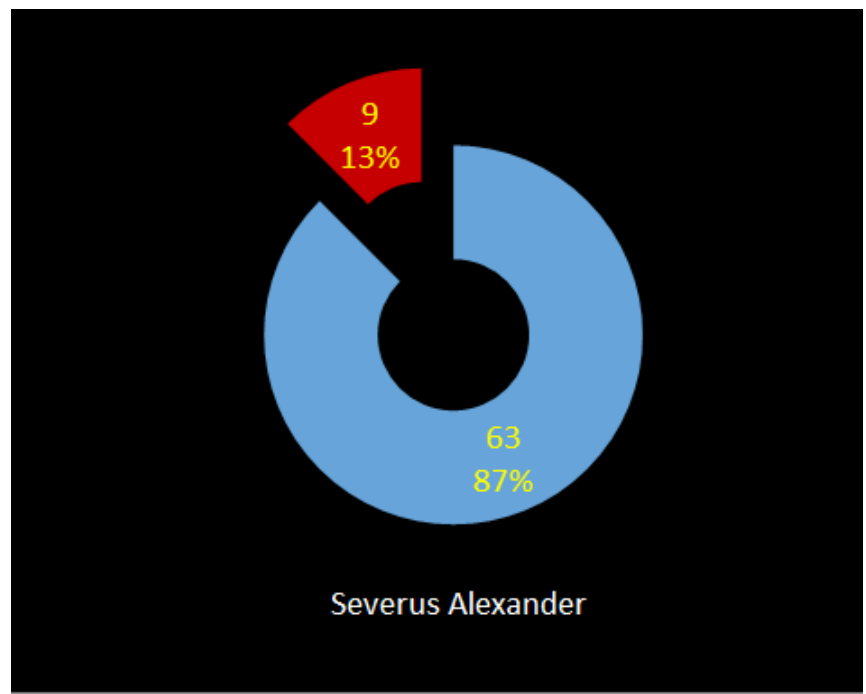

Fig. 101

\section{Hofheim-Main-Taunus (Germany)}

For the site of Hofheim-Main-Taunus ${ }^{147}$ we have Fig. 102 for pieces dated during Septimius Severus (193211), $94 \%$ are genuine, 48 pieces, while $6 \%$ are plated, three pieces. Fig 103 shows dated pieces during the reign

\footnotetext{
146 FMRD 2006a, 33.

147 FMRD 1994a.
}

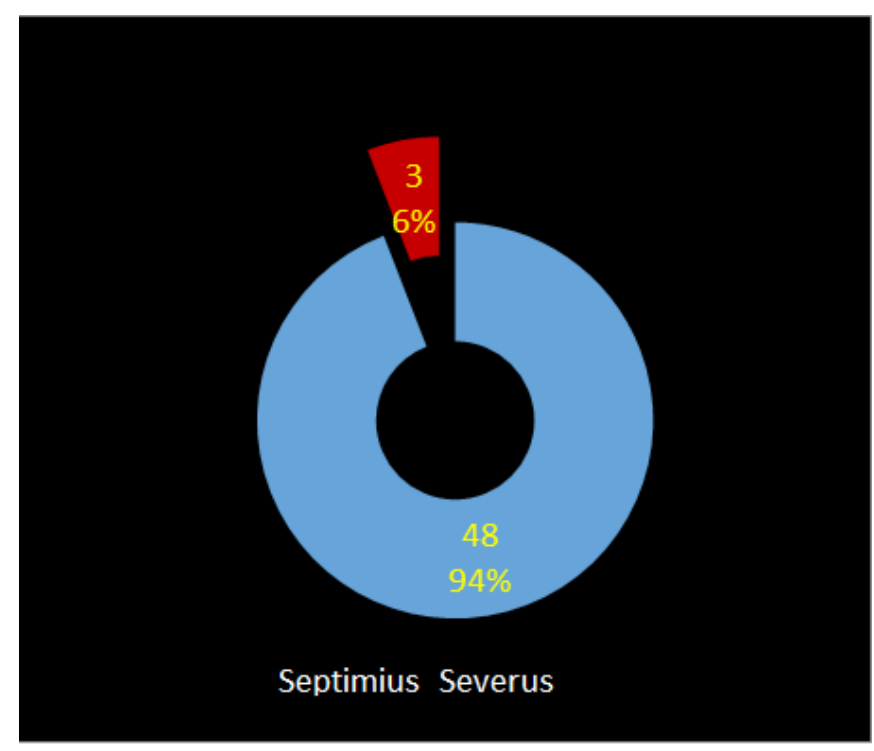

Fig. 102

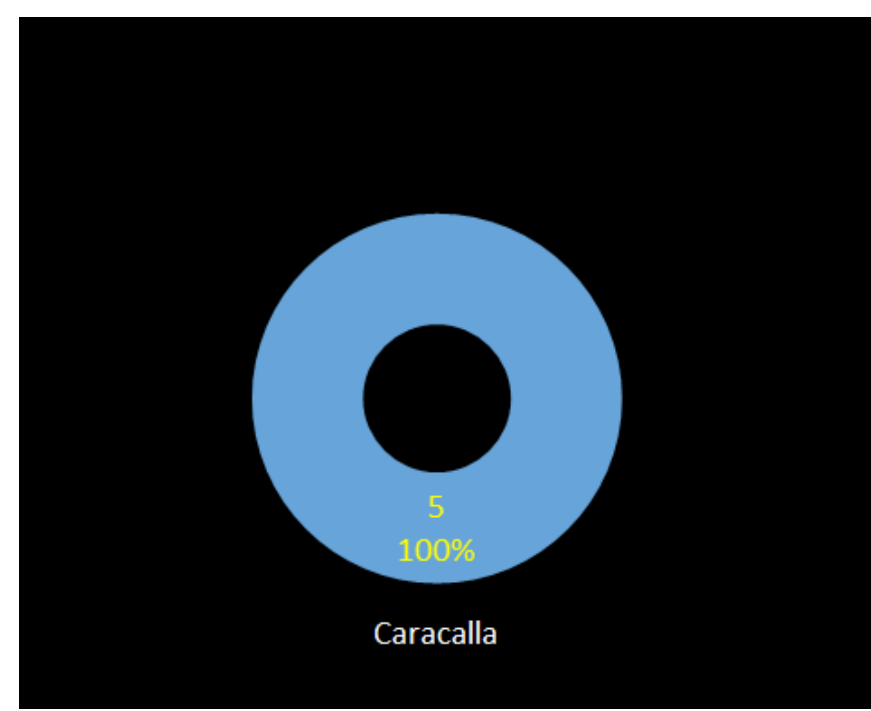

Fig. 103

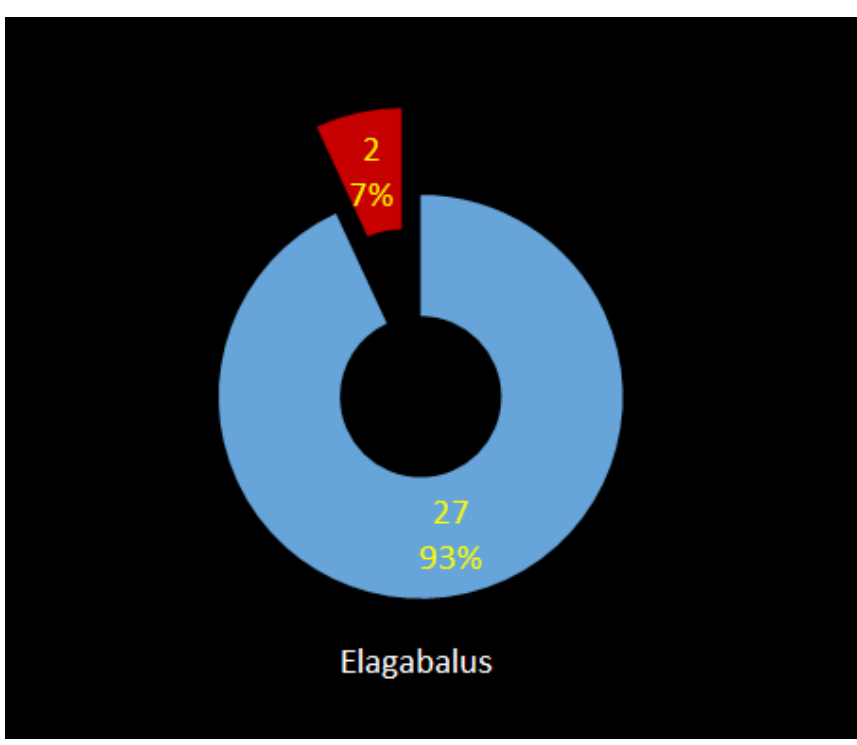

Fig. 104 


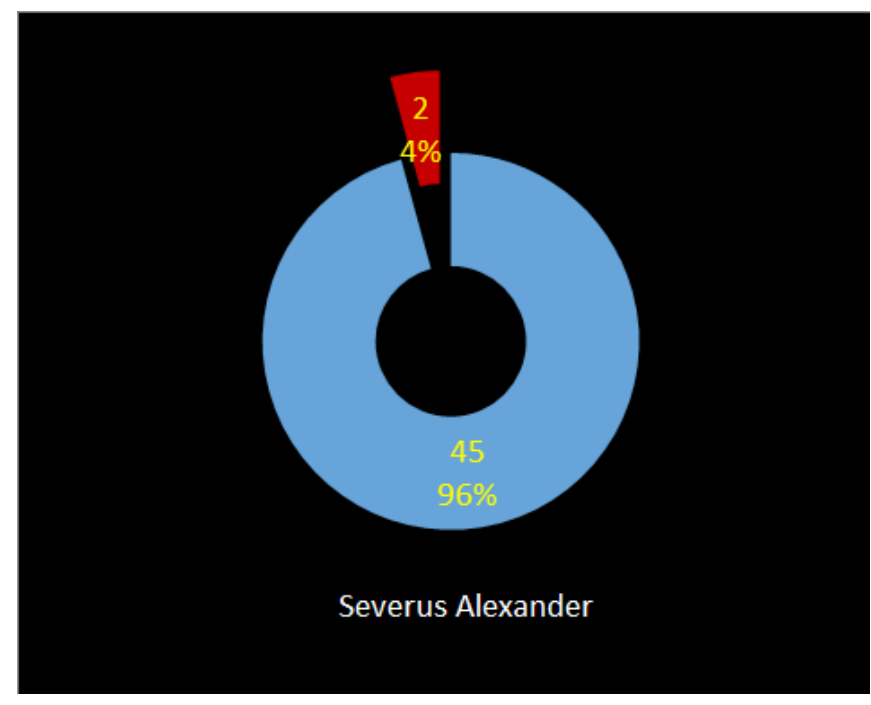

Fig. 105

of Caracalla (211-217), 100\% are genuine, five coins. Fig. 104 for pieces dated during Elagabalus (218-222), 93\% are genuine, 27 coins, while 7\% are plated, two coins. Fig. 105 for pieces dated during Severus Alexander (222-235), 96\% are genuine, 45 coins, while $4 \%$ are plated, two coins.

\section{Zugmantel (Germany)}

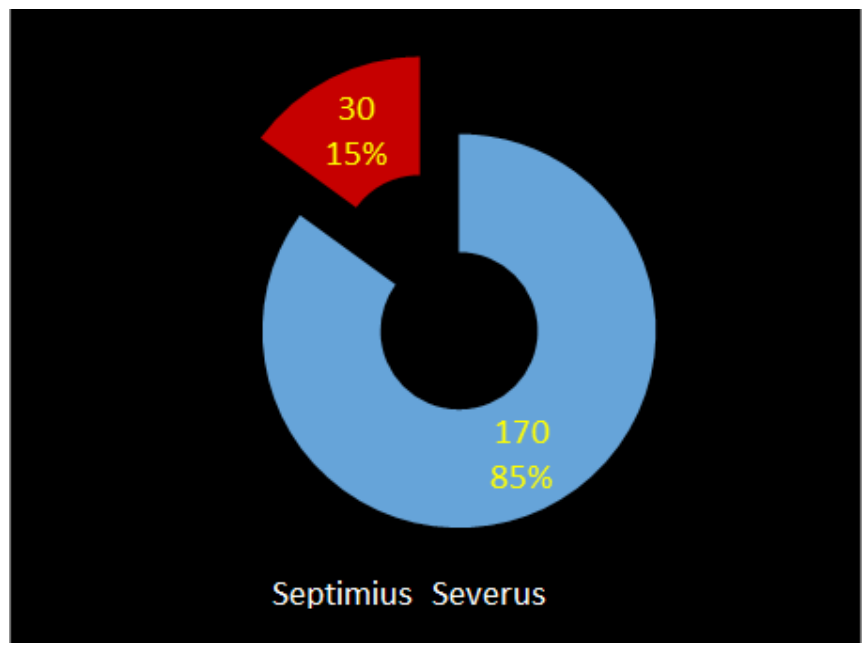

Fig. 106

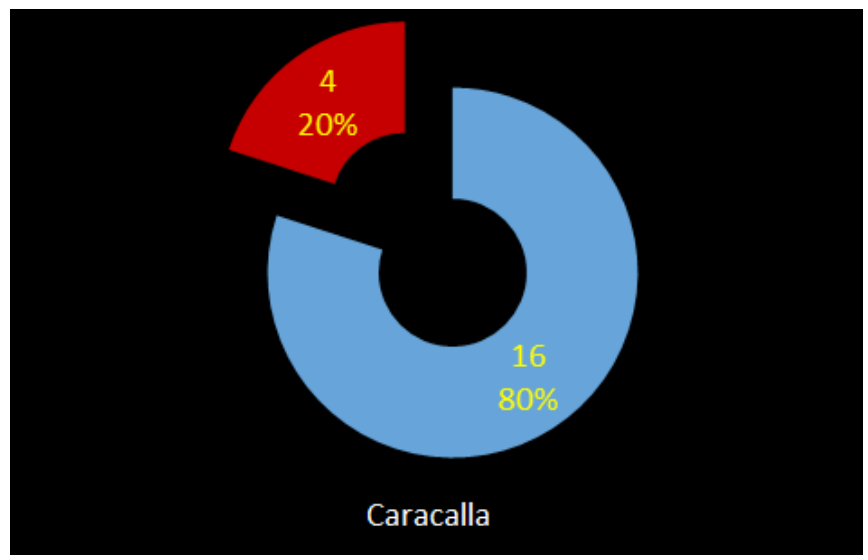

Fig. 107

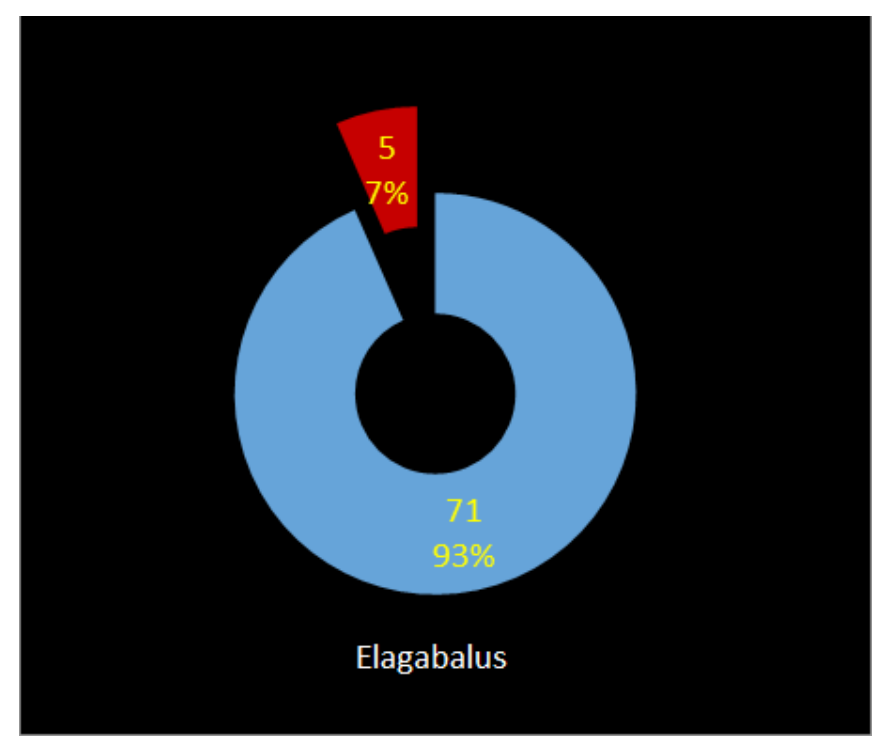

Fig. 108

Zugmantel ${ }^{148}$ seen in Fig. 106 regarding the reign of Septimius Severus (193-211) with a proportion of $85 \%$ genuine pieces, 170 coins, and 15\% plated pieces, 30 coins. Fig. 107 regarding the reign of Caracalla (211-217) with a proportion of $80 \%$ genuine pieces, 16 coins, and $20 \%$ plated pieces, four coins. Fig. 108 regarding the reign of Elagabalus (218-222) with a proportion of $93 \%$ genuine pieces, 71 coins, and $7 \%$ plated pieces, five coins. Fig 109 regarding the reign of Severus Alexander (222-235) with a proportion of $92 \%$ genuine pieces, 121 coins, and $8 \%$ plated pieces, 10 coins.

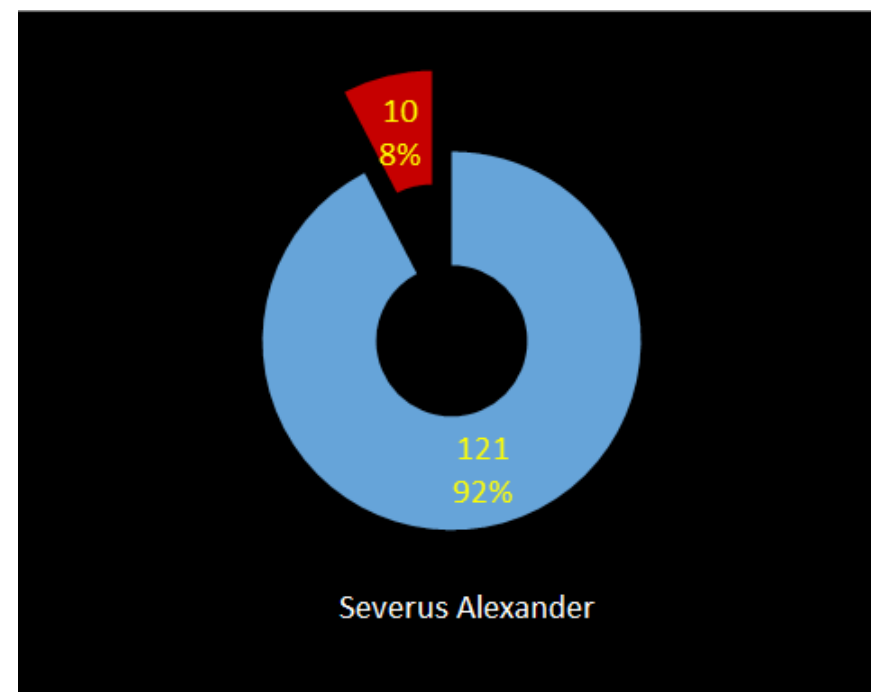

Fig. 109

Trier - Colonia Augusta Treverorum (Germany)

For the site of Augusta Treverorum ${ }^{149}$ we have Fig. 110 for pieces dated during Septimius Severus (193-211), 97\% are genuine, 112 pieces, while $3 \%$ are plated, three pieces. Fig 111 shows dated pieces during the reign of Caracalla (211217), 96\% are genuine, 25 coins, $4 \%$ are plated, one coin. Fig. 112 for pieces dated during Elagabalus (218-222), 97\% are

148 FMRD 1994b.

149 FMRD 2004. FMRD 2006b. FMRD 2007. 


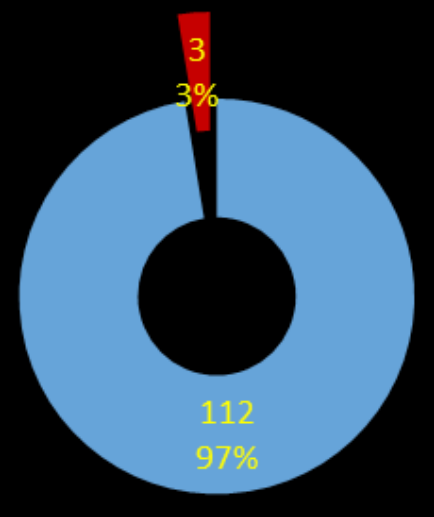

Septimius Severus

Fig. 110

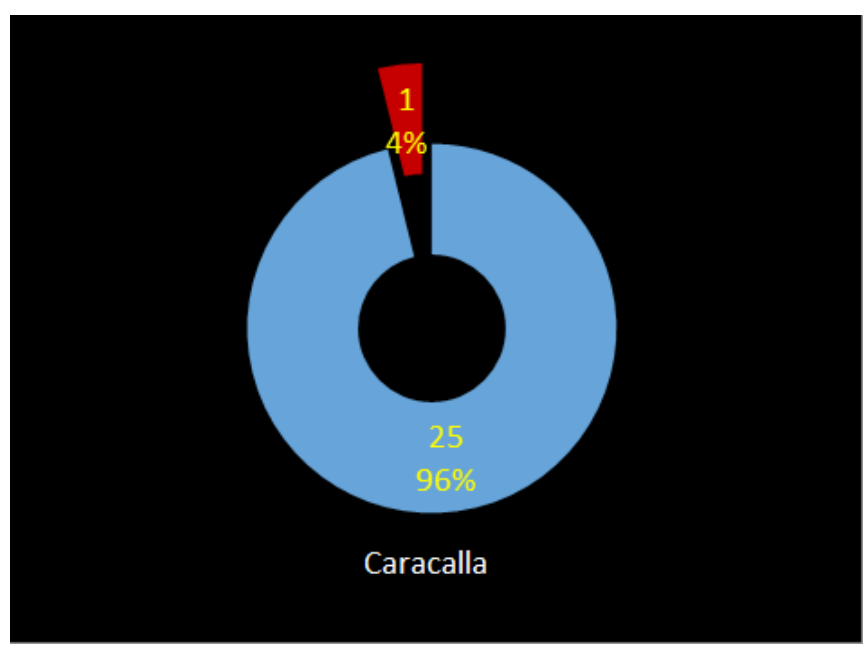

Fig. 111

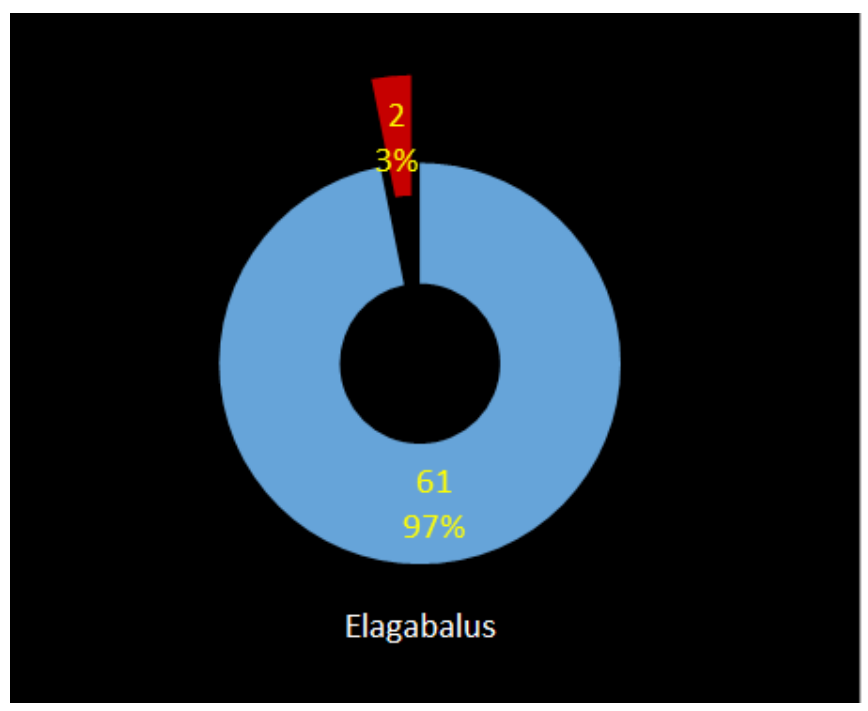

Fig. 112

genuine, 61 coins, while $3 \%$ are plated, two coins. Fig. 113 for pieces dated during Severus Alexander (222-235), 100\% are genuine, 47 coins.

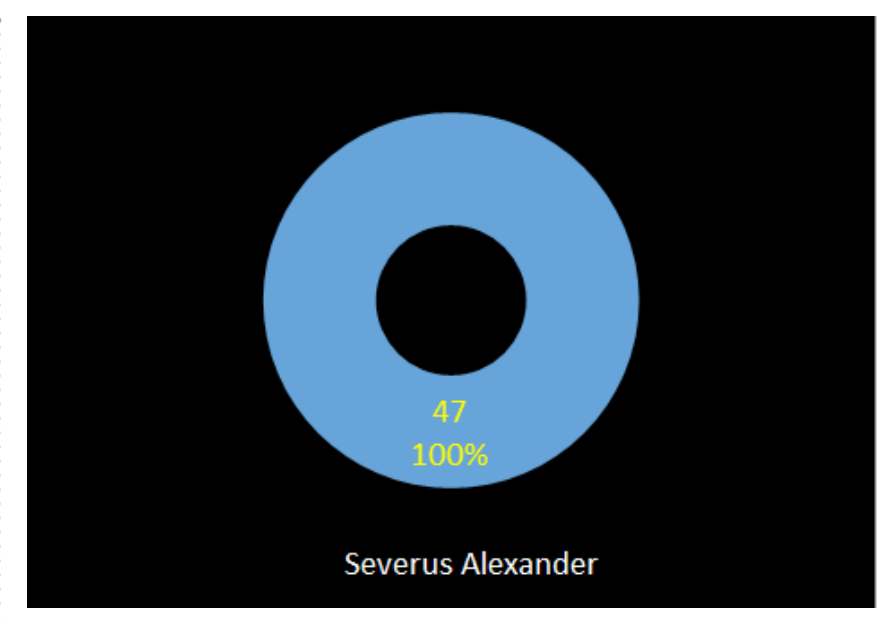

Fig. 113

Next follows a few sites from the Middle Danube region, to have a comparative view between the Rhine and Danube regions.

\section{Porolissum (Romania)}

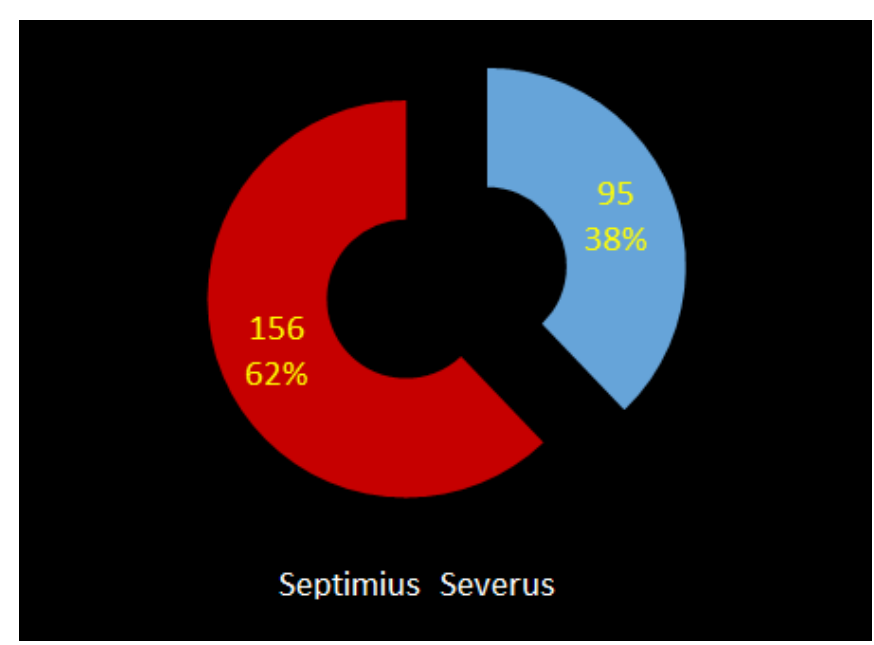

Fig. 114

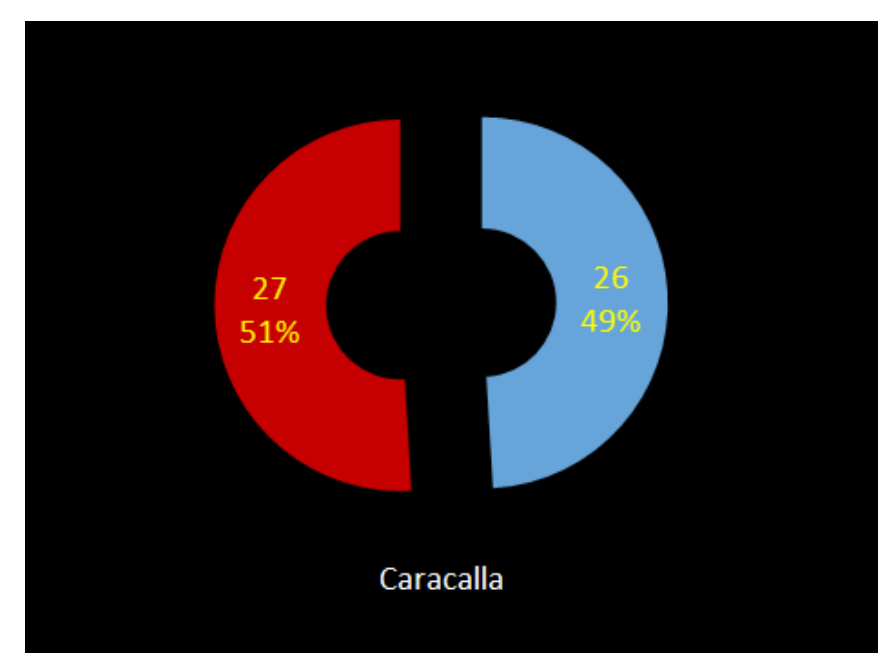

Fig. 115 


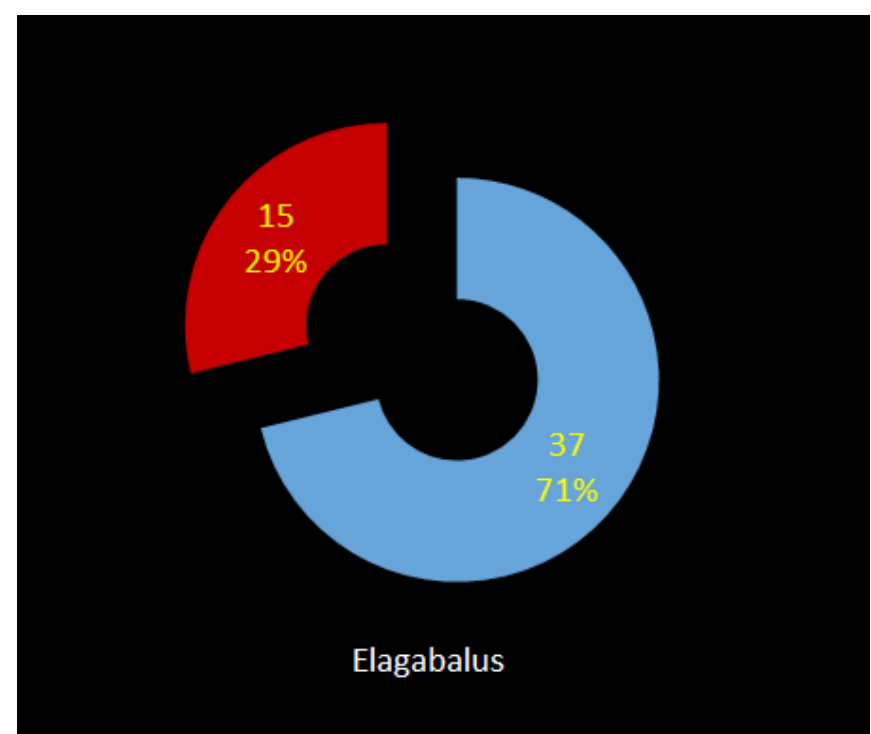

Fig. 116

Porolissum $^{150}$ seen in Fig. 114 regarding the reign of Septimius Severus (193-211) with a proportion of $38 \%$ genuine pieces, 95 coins, and $62 \%$ plated pieces, 156 coins. Fig. 115 regarding the reign of Caracalla (211-217) with a proportion of $49 \%$ genuine pieces, 26 coins, and $51 \%$ plated pieces, 27 coins. Fig. 116 regarding the reign of Elagabalus (218-222) with a proportion of $71 \%$ genuine pieces, 37 coins, and $29 \%$ plated pieces, 15 coins. Fig 117 regarding the reign of Severus Alexander (222-235) with a proportion of $67 \%$ genuine pieces, 74 coins, and $33 \%$ plated pieces, 37 coins.

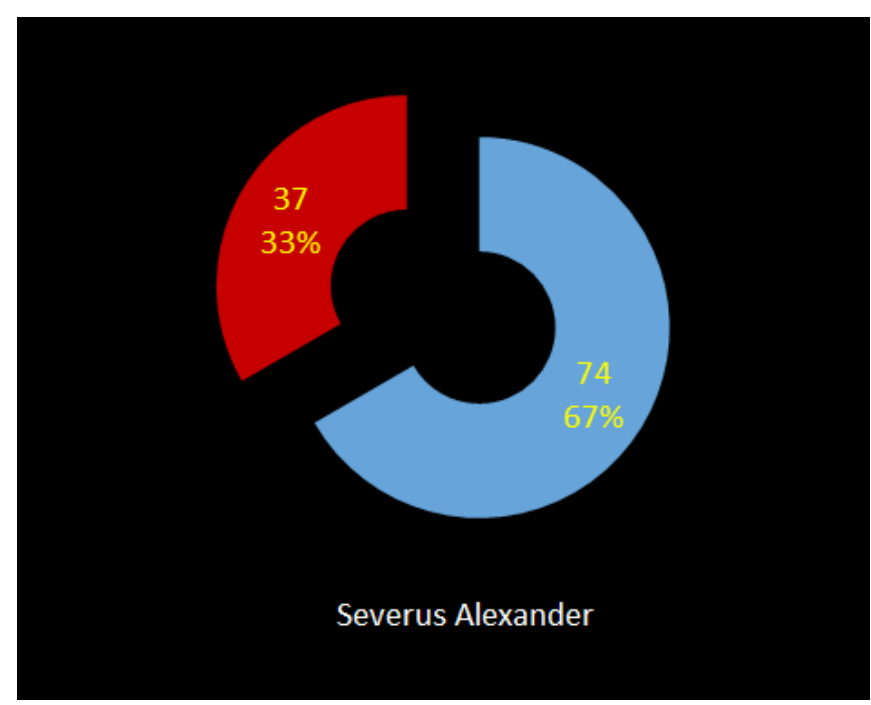

Fig. 117

\section{Arcobadara (Romania)}

For the site of Arcobadara ${ }^{151}$ we have Fig. 118 for pieces dated during Septimius Severus (193-211), 51\% are genuine, 38 pieces, while $49 \%$ are plated, 37 pieces. Fig 119 shows dated pieces during the reign of Caracalla (211-217), $62 \%$ are genuine, five coins, $38 \%$ are plated, three coins. Fig. 120 for pieces dated during Elagabalus (218-222), 67\% are

\footnotetext{
150 GĂZDAC/GUDEA 2006.

151 GĂZDAC/GAIU 2011.
}

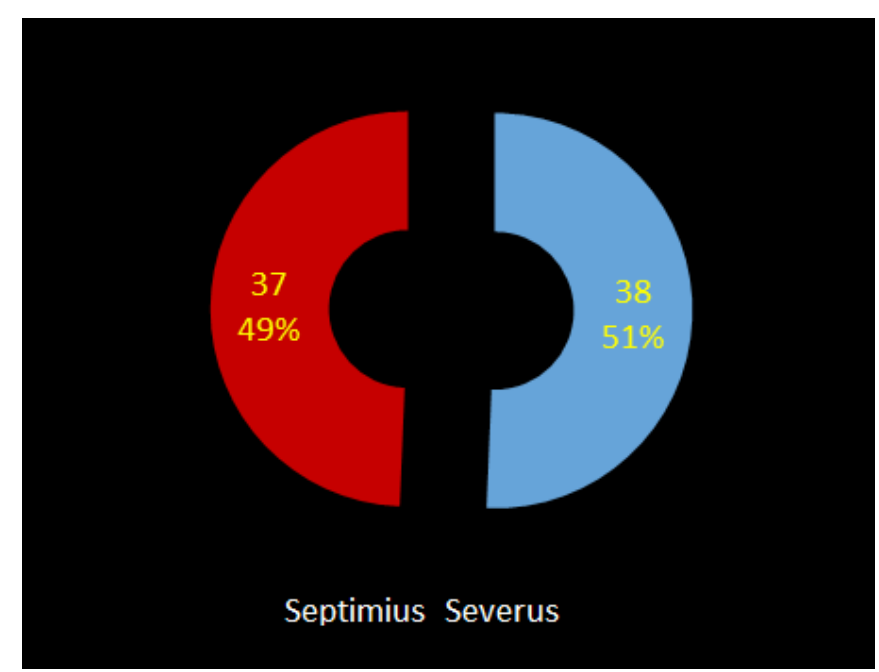

Fig. 118

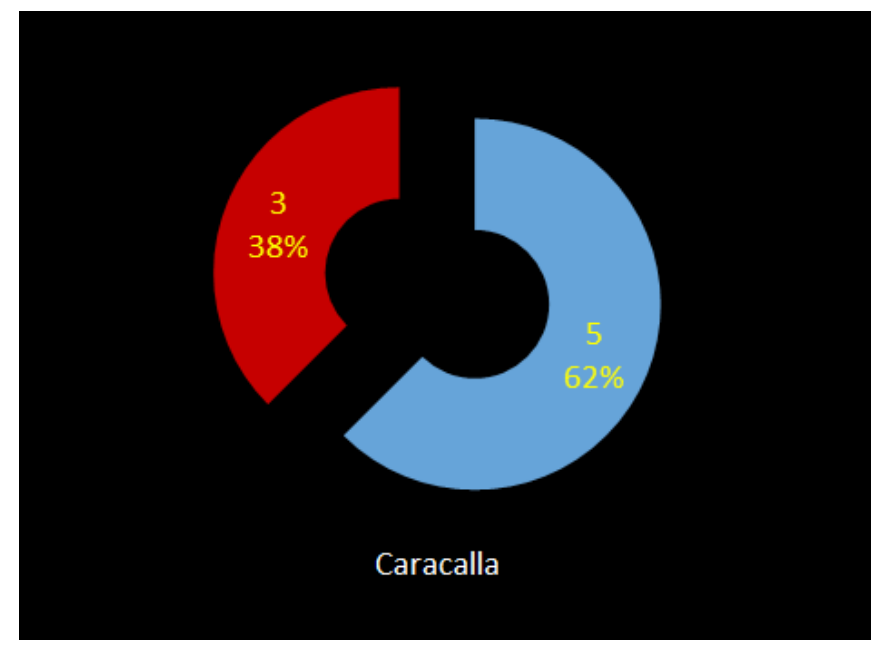

Fig. 119

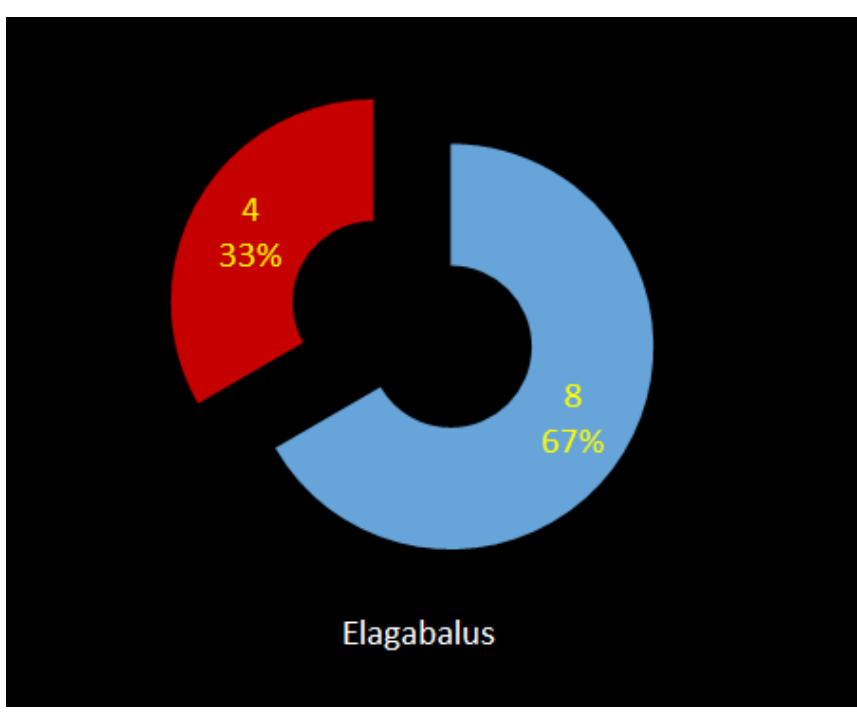

Fig. 120

genuine, eight coins, while $33 \%$ are plated, four coins. Fig. 121 for pieces dated during Severus Alexander (222-235), $69 \%$ are genuine, 25 coins, while $31 \%$ are plated, 11 coins. 


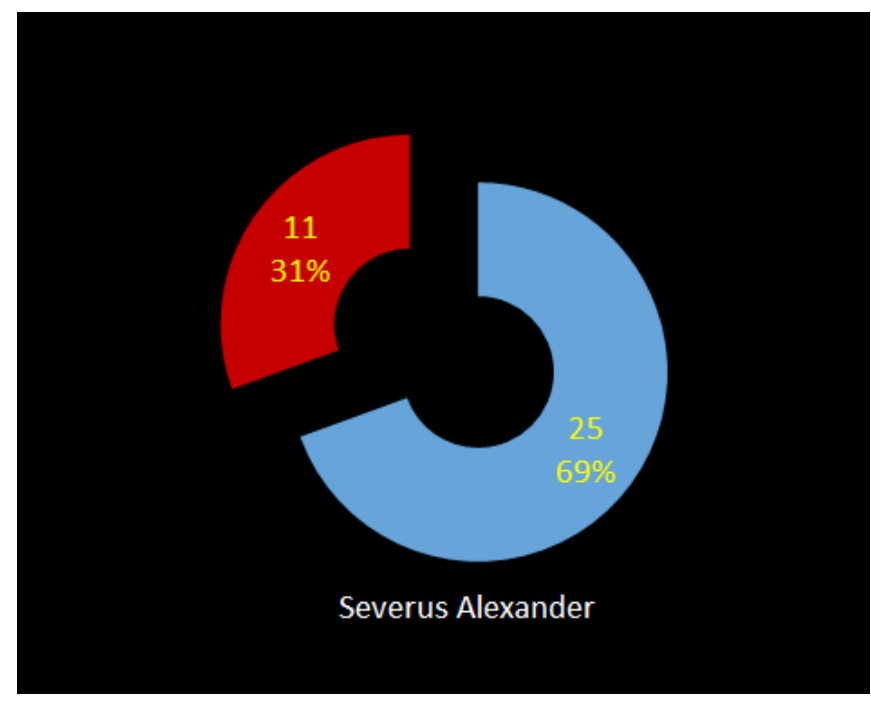

Fig. 121

\section{Turda - Potaissa (Romania)}

Potaissa ${ }^{152}$ seen in Fig. 122 regarding the reign of Septimius Severus (193-211) with a proportion of $87 \%$

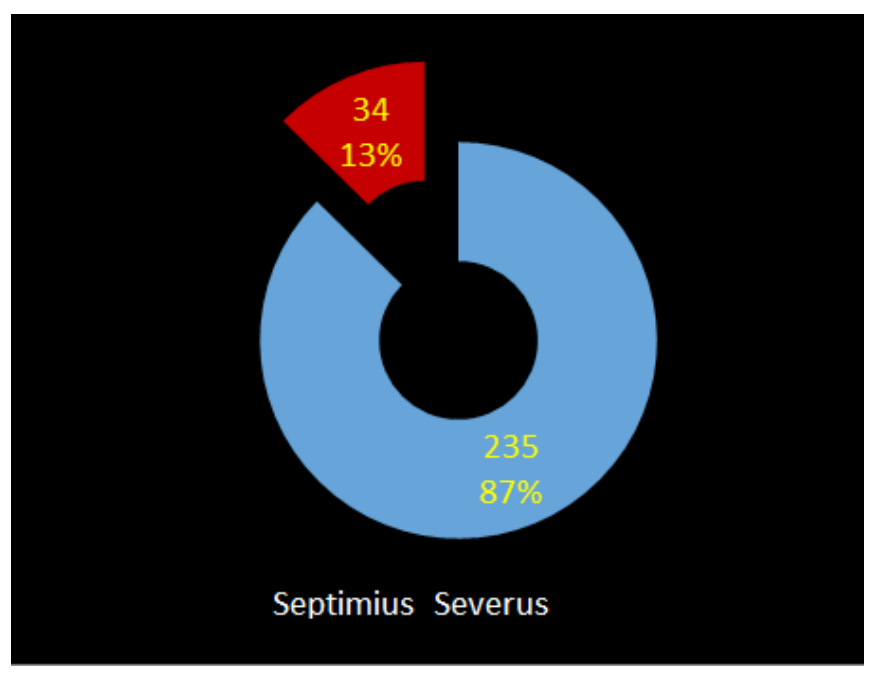

Fig. 122

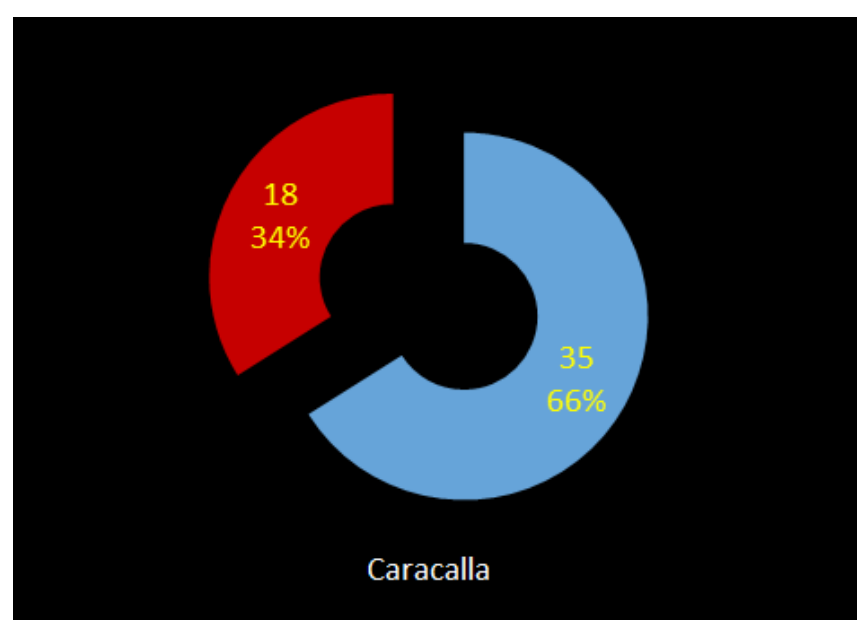

Fig. 123

152 PÎSLARU 2009.

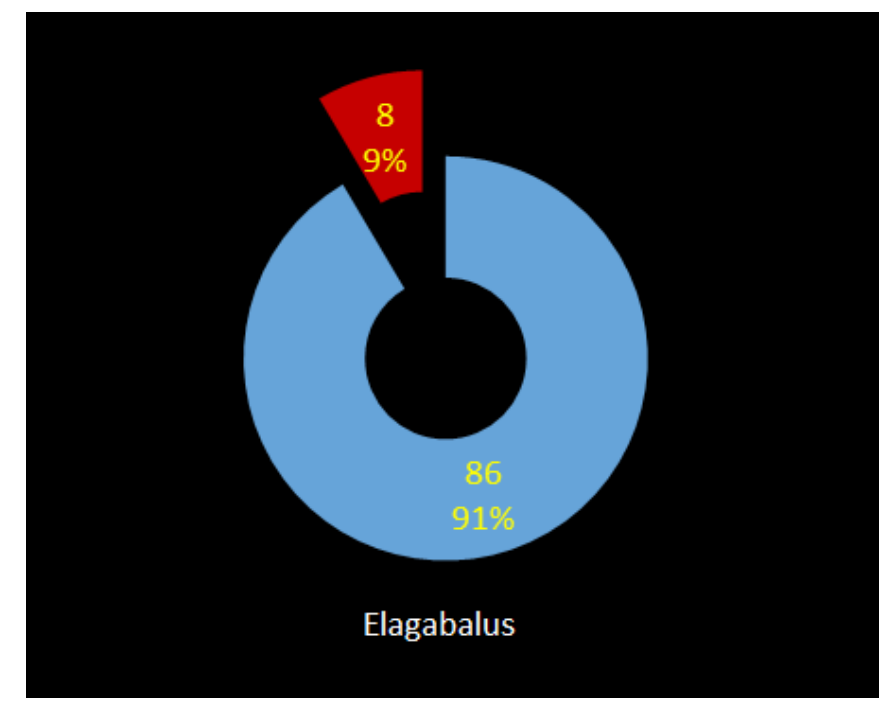

Fig. 124

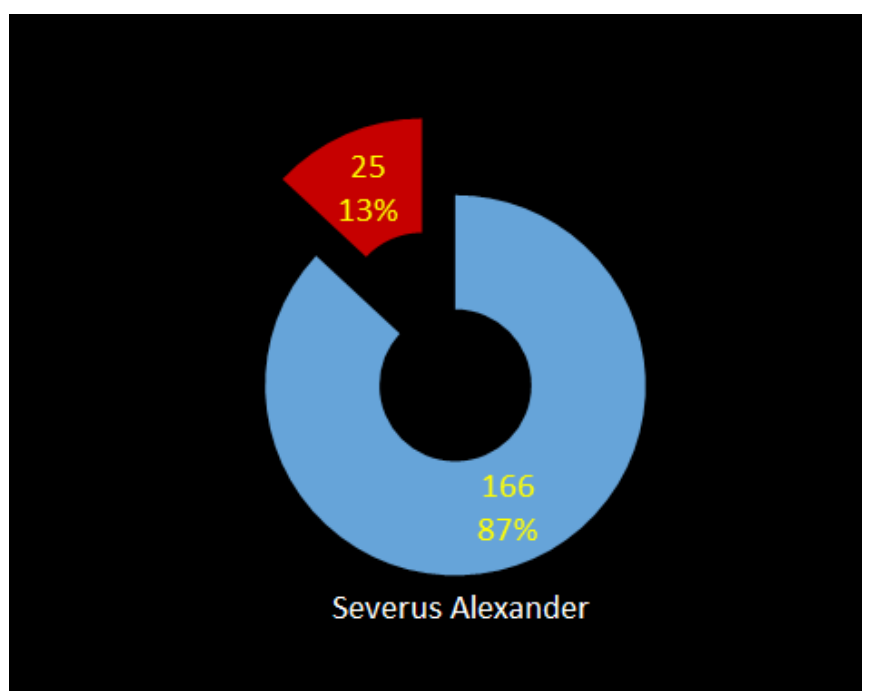

Fig. 125

genuine pieces, 235 coins, and 13\% plated and cast pieces, 34 coins. Fig. 123 regarding the reign of Caracalla (211-217) with a proportion of $66 \%$ genuine pieces, 35 coins, and $34 \%$ plated and cast pieces, 18 coins. Fig. 124 regarding the reign of Elagabalus (218-222) with a proportion of $91 \%$ genuine pieces, 86 coins, and $9 \%$ plated and cast pieces, eight coins. Fig 125 regarding the reign of Severus Alexander (222-235) with a proportion of $87 \%$ genuine pieces, 166 coins, and $13 \%$ plated pieces, 25 coins.

\section{Alba Iulia - Apulum (Romania)}

For the site of Apulum ${ }^{153}$ we have Fig. 126 for pieces dated during Septimius Severus (193-211), 46\% are genuine, 67 pieces, while 54\% are plated, 78 pieces. Fig 127 shows dated pieces during the reign of Caracalla (211-217), 31\% are genuine, nine coins, $69 \%$ are plated, 20 coins. Fig. 128 for pieces dated during Elagabalus (218-222), 49\% are genuine, 35 coins, while 51\% are plated, 37 coins. Fig. 129 for pieces dated during Severus Alexander (222-235), 51\% are genuine, 68 coins, while $49 \%$ are plated, 66 coins.

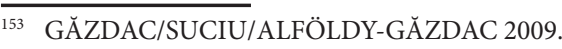




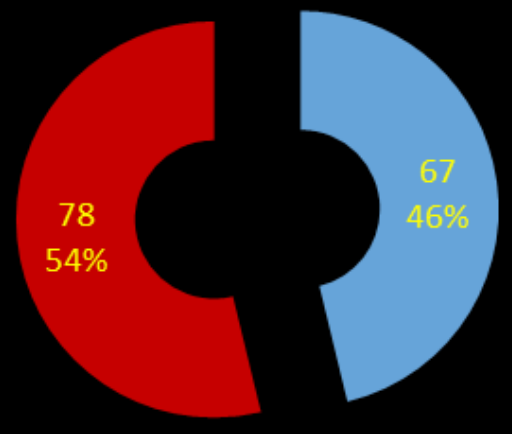

Septimius Severus

Fig. 126

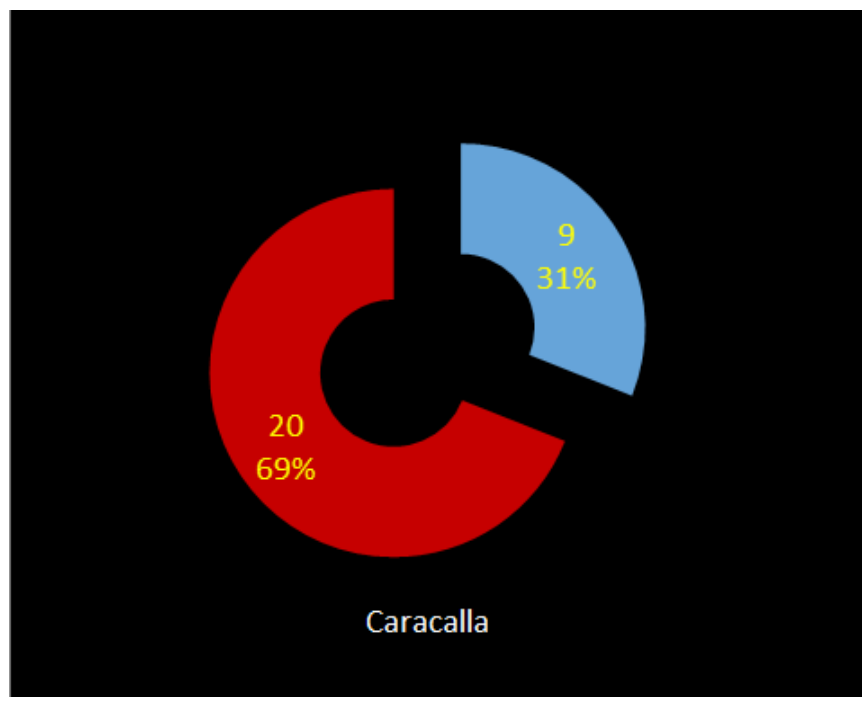

Fig. 127

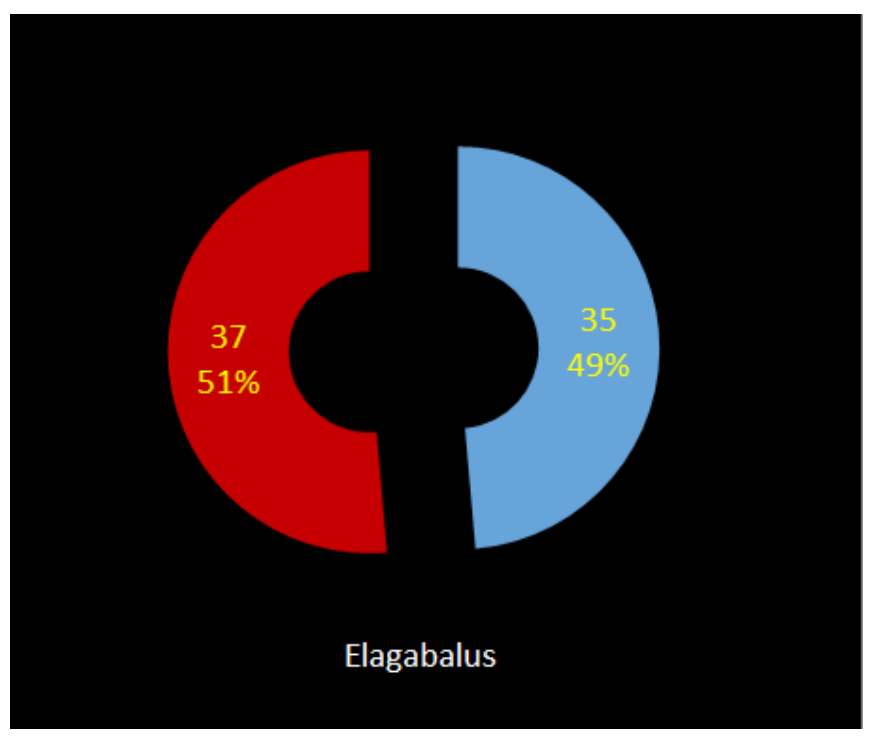

Fig. 128

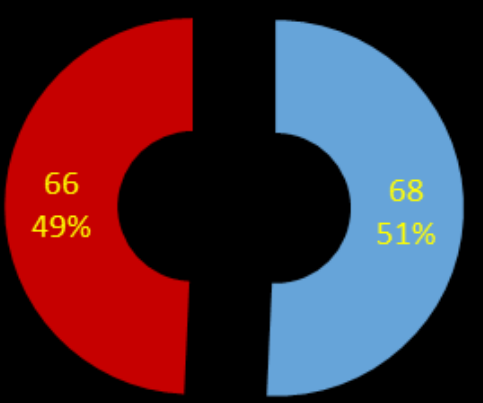

Severus Alexander

Fig. 129

Ulpia Traiana Sarmizegetusa (Romania)

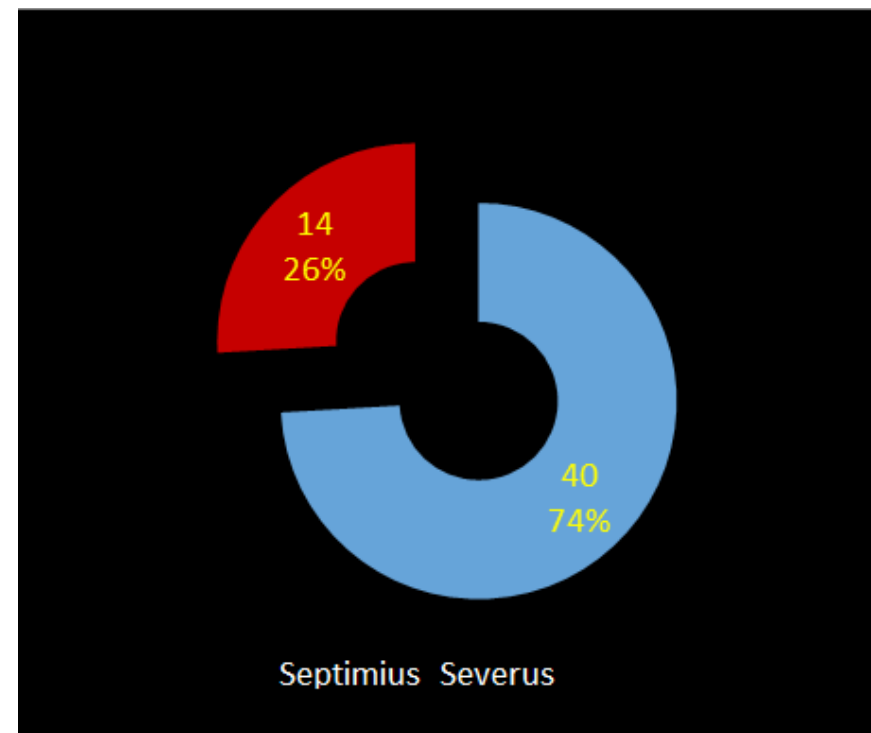

Fig. 130

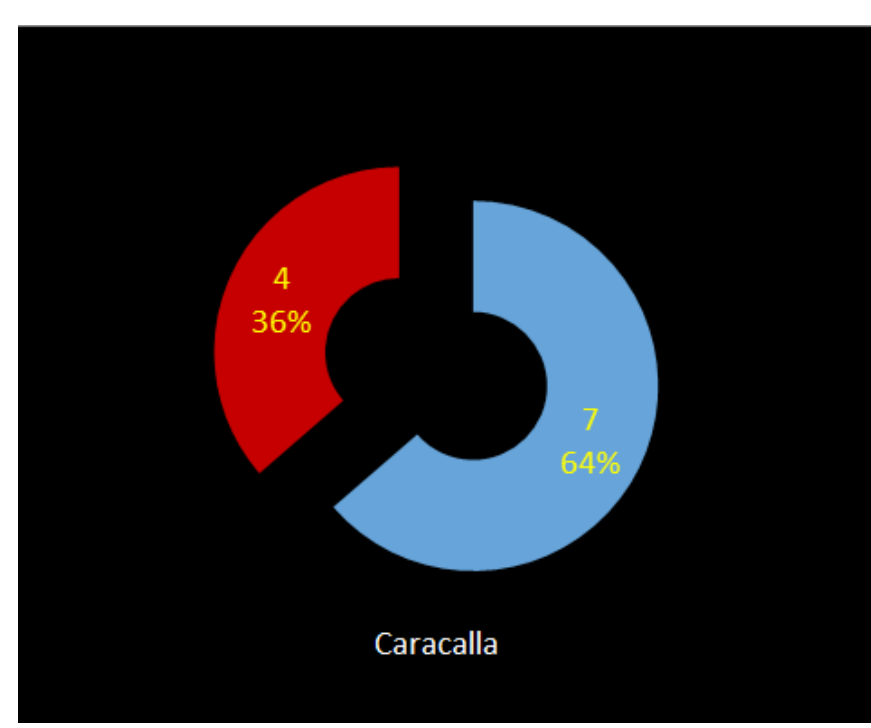

Fig. 131 


\section{Studies}

Ulpia Traiana Sarmizegetusa ${ }^{154}$ seen in Fig. 130 regarding the reign of Septimius Severus (193-211) with a proportion of $74 \%$ genuine pieces, 40 coins, and $26 \%$ plated pieces, 14 coins. Fig. 131 regarding the reign of Caracalla (211-217) with a proportion of $64 \%$ genuine pieces, seven coins, and $36 \%$ plated pieces, four coins. Fig. 132 regarding the reign of Elagabalus (218-222) with a proportion of $89 \%$ genuine pieces, 17 coins, and $11 \%$ plated pieces, two coins. Fig 133 regarding the reign of Severus Alexander (222-235) with a proportion of $82 \%$ genuine pieces, 37 coins, and $18 \%$ plated pieces, eight coins.

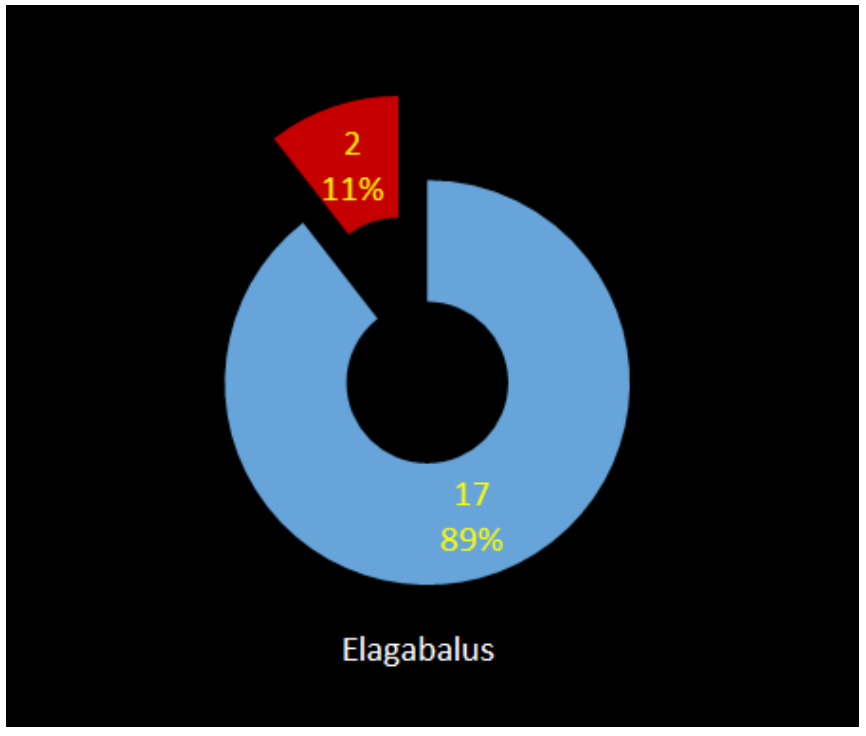

Fig. 132

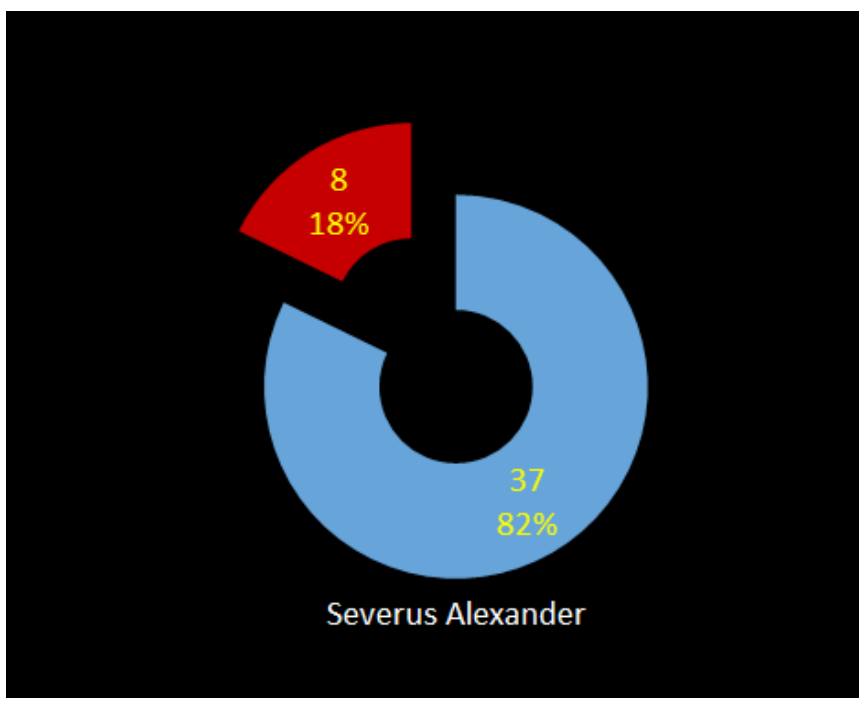

Fig. 133

\section{Dunaújváros - Intercisa (Hungary)}

For the site of Intercisa ${ }^{155}$ we have Fig. 134 for pieces dated during Septimius Severus (193-211), 51\% are genuine, 38 pieces, while $49 \%$ are plated, 37 pieces. Fig 135 shows

${ }_{154}$ GĂZDAC/COCIŞ 2004 .

155 FMRU I, 1990.

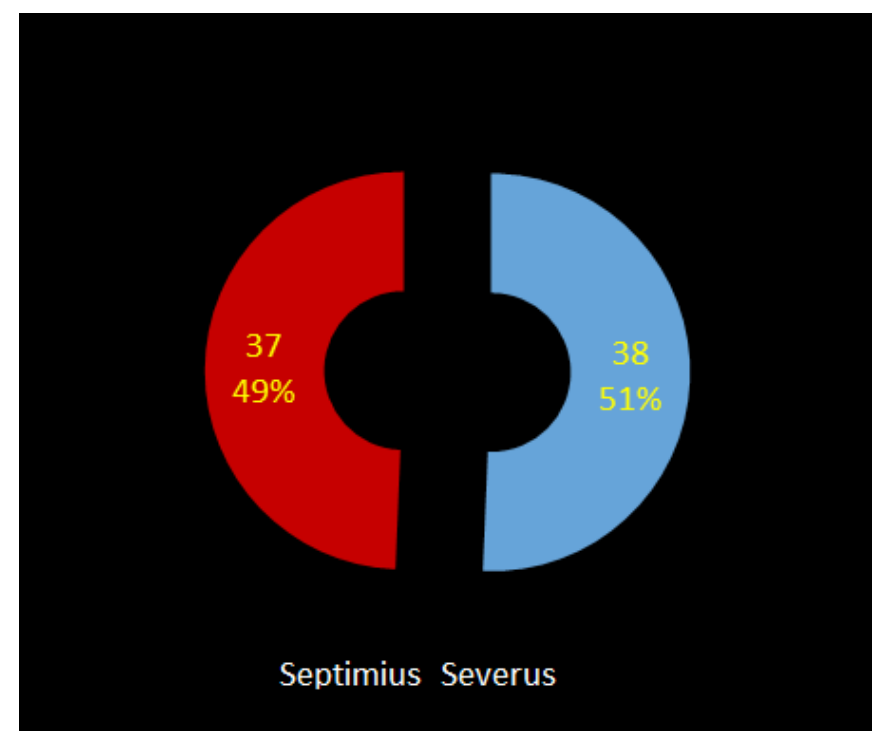

Fig. 134

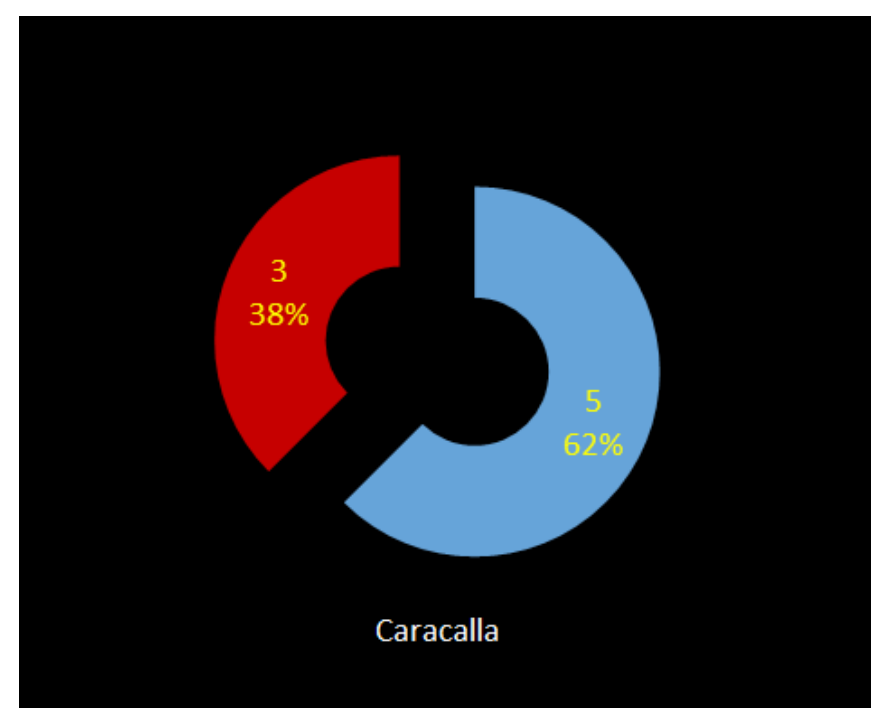

Fig. 135

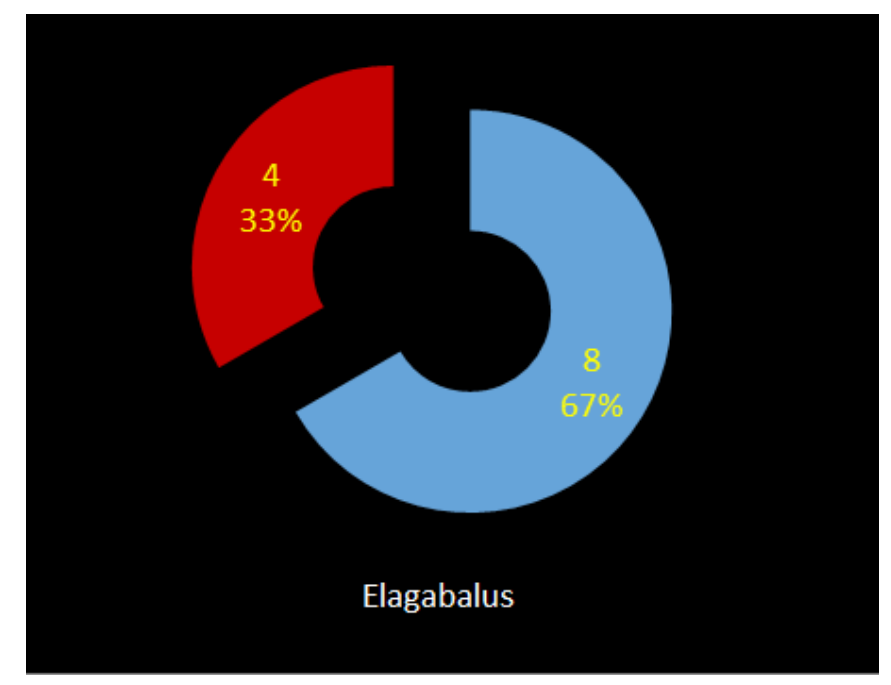

Fig. 136

dated pieces during the reign of Caracalla (211-217), 62\% are genuine, five coins, 38\% are plated, three coins. Fig. 136 for 


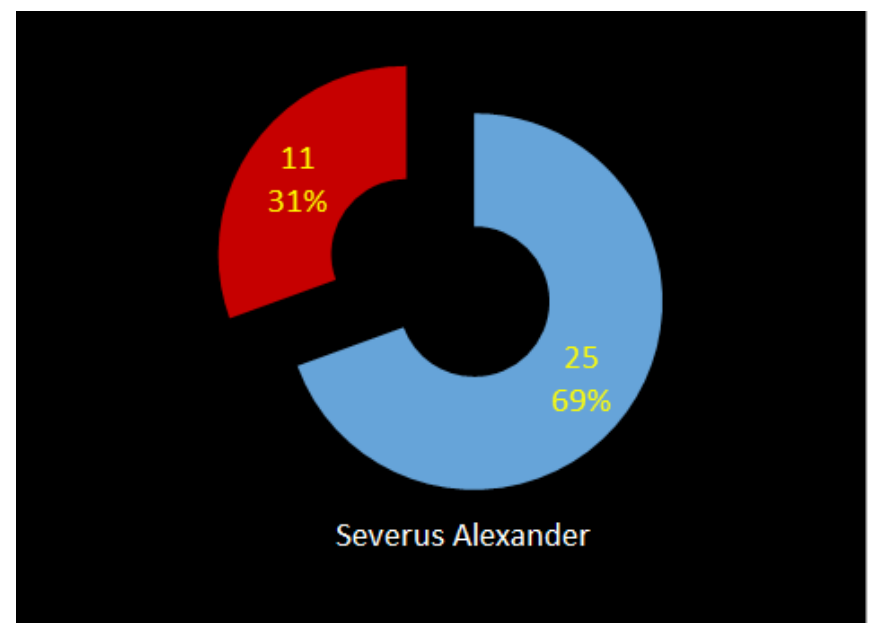

Fig. 137

pieces dated during Elagabalus (218-222), 67\% are genuine, eight coins, while $33 \%$ are plated, four coins. Fig. 137 for pieces dated during Severus Alexander (222-235), 69\% are genuine, 25 coins, while $31 \%$ are plated, 11 coins.

\section{Tác - Gorsium-Herculia (Hungary)}

Gorsium-Herculia ${ }^{156}$ seen in Fig. 138 regarding the reign of Septimius Severus (193-211) with a proportion of $100 \%$ genuine pieces, 24 coins. Fig. 139 regarding the reign of Caracalla (211-217) with a proportion of $88 \%$

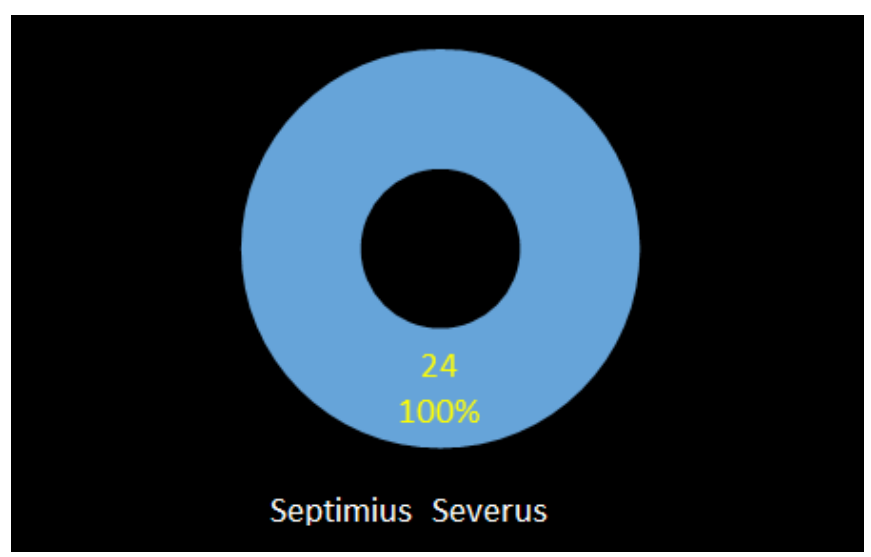

Fig. 138

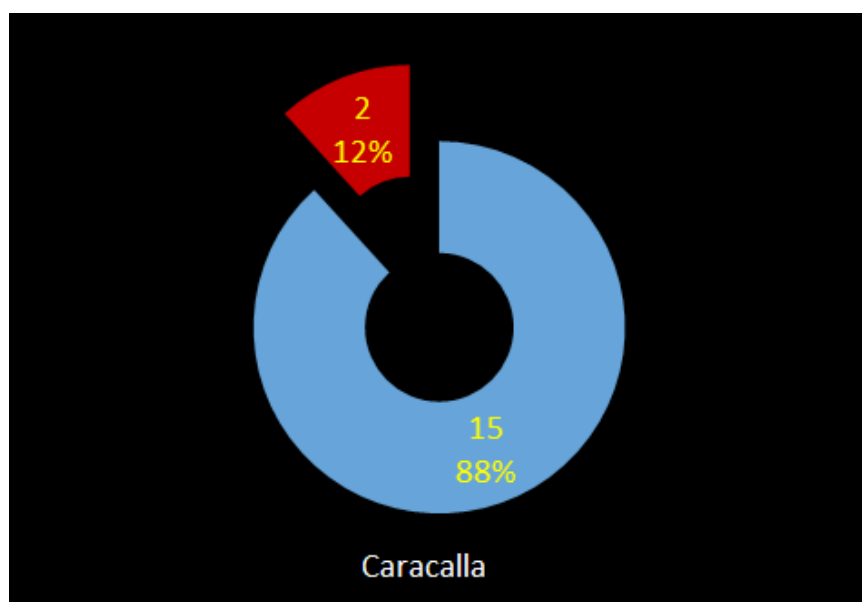

156 FMRU I, 1990.
Fig. 139

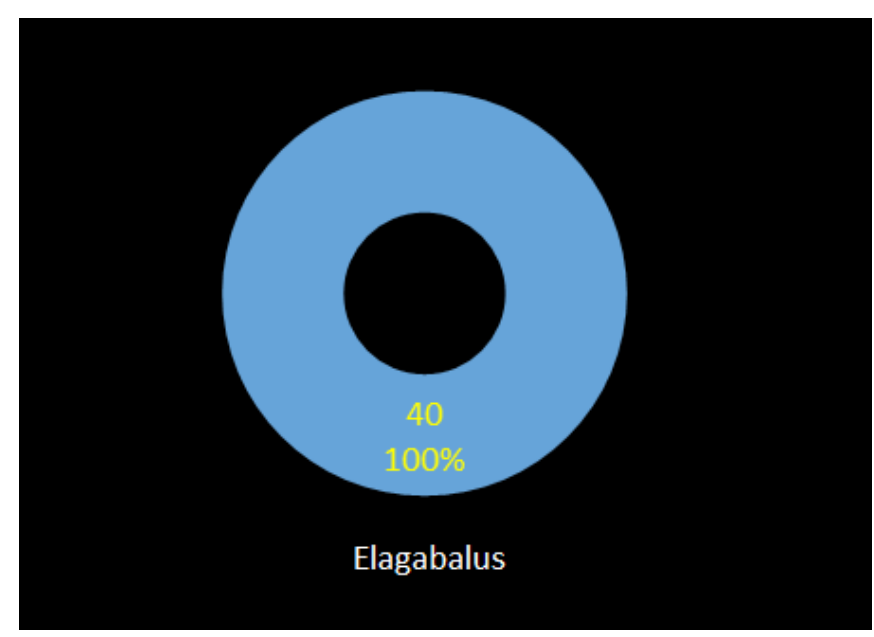

Fig. 140

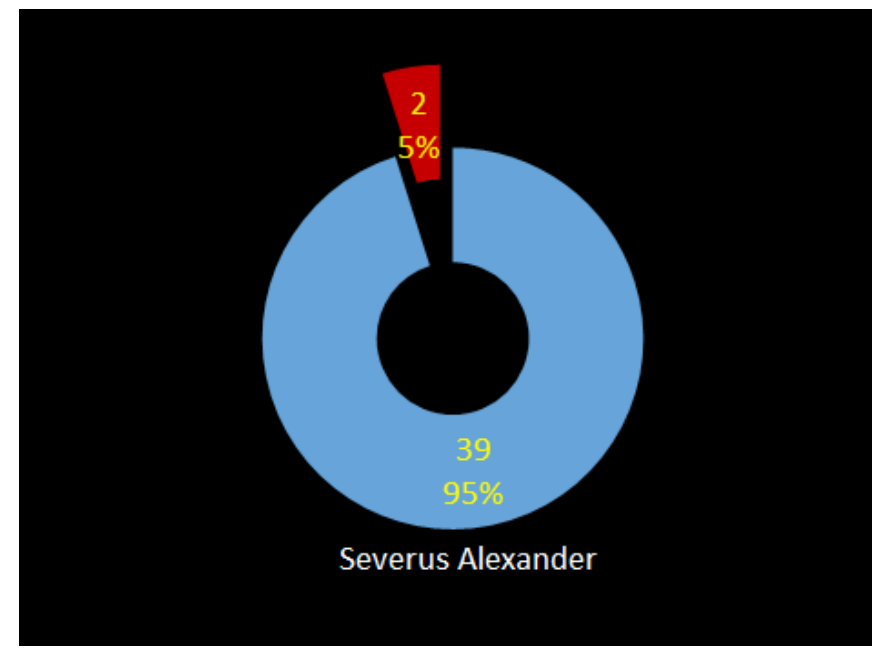

Fig. 141

genuine pieces, 15 coins, and $12 \%$ plated pieces, two coins. Fig. 140 regarding the reign of Elagabalus (218-222) with a proportion of $100 \%$ genuine pieces, 40 coins. Fig 141 regarding the reign of Severus Alexander (222-235) with a proportion of $95 \%$ genuine pieces, 39 coins, and 5\% plated pieces, two coins.

\section{Szőny - Brigetio (Hungary)}

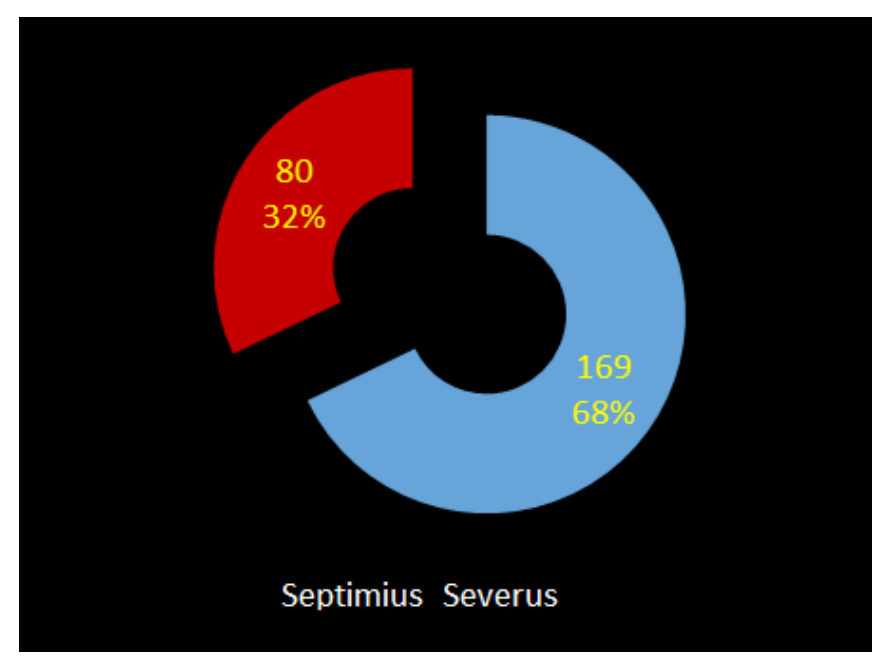

Fig. 142 


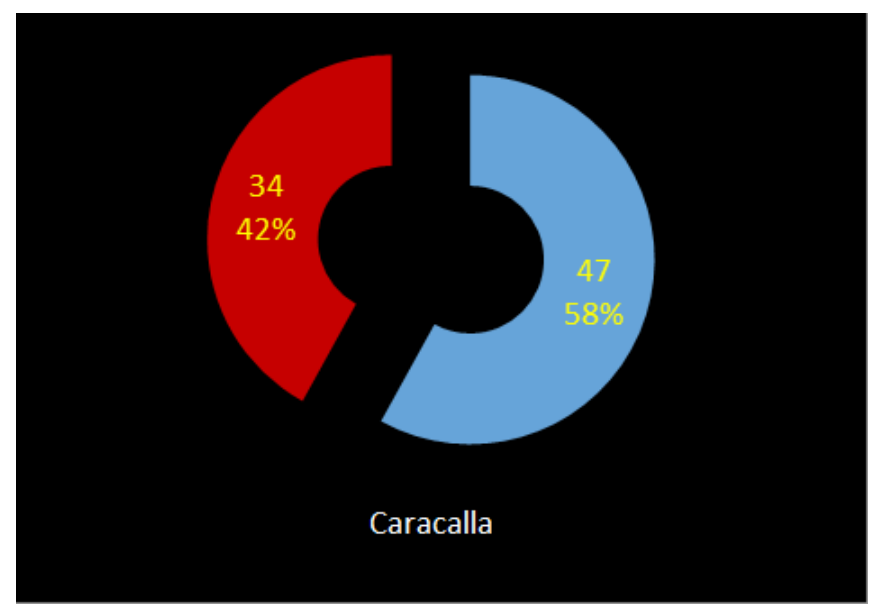

Fig. 143

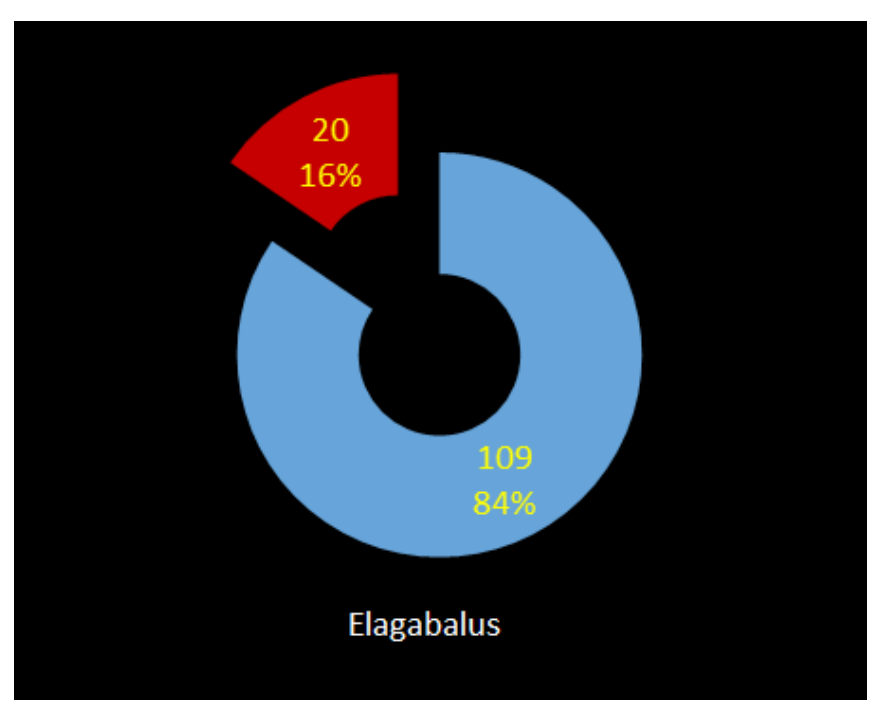

Fig. 144

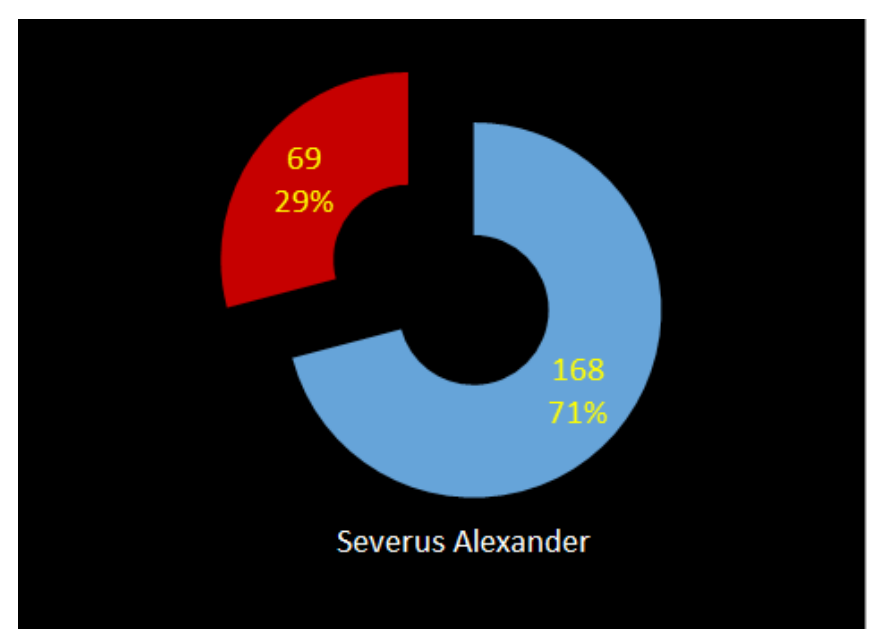

Fig. 145

For the site of Brigetio ${ }^{157}$ we have Fig. 142 for pieces dated during Septimius Severus (193-211), 68\% are genuine, 169 pieces, while $32 \%$ are plated, 80 pieces. Fig 143 shows dated pieces during the reign of Caracalla (211-217), 58\% are genuine, 47 coins, $42 \%$ are plated, 34 coins. Fig. 144 for pieces dated during Elagabalus (218-222), 84\% are genuine, 157 FMRU III, 1999.
109 coins, while $16 \%$ are plated, 20 coins. Fig. 145 for pieces dated during Severus Alexander (222-235), 71\% are genuine, 168 coins, while $29 \%$ are plated, 69 coins.

\section{Carnuntum (Austria)}

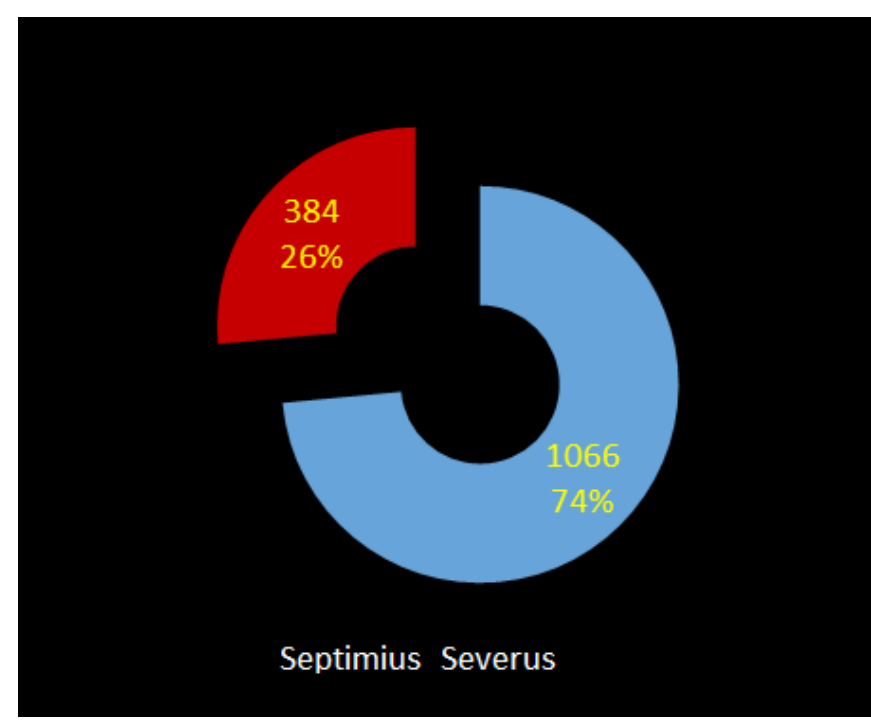

Fig. 146

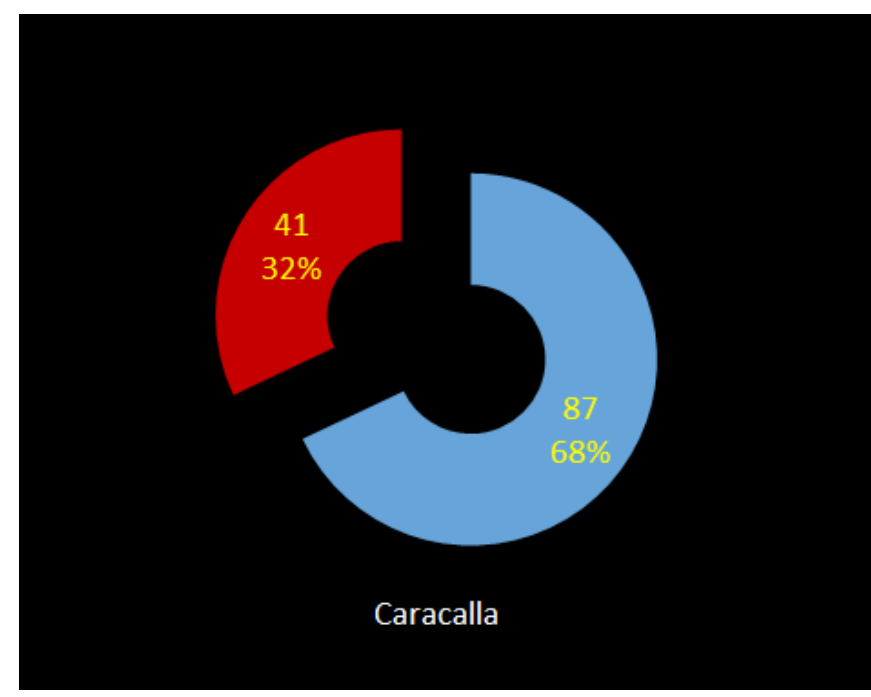

Fig. 147

Last but not least we have the site of Carnuntum seen in Fig. 146 regarding the reign of Septimius Severus (193-211) with a proportion of 74\% genuine pieces, 1066 coins, and 26\% plated pieces, 384 coins. Fig. 147 regarding the reign of Caracalla (211-217) with a proportion of $68 \%$ genuine pieces, 87 coins, and 32\% plated pieces, 41 coins. Fig. 148 regarding the reign of Elagabalus (218-222) with a proportion of $83 \%$ genuine pieces, 511 coins, and $17 \%$ plated pieces, 103 coins. Fig 149 regarding the reign of Severus Alexander (222-235) with a proportion of $72 \%$ genuine pieces, 703 coins, and $28 \%$ plated pieces, 279 coins.

Using the information provided by pie charts regarding the Severian dynasty and with the help of geography it was possible to create new representations, 


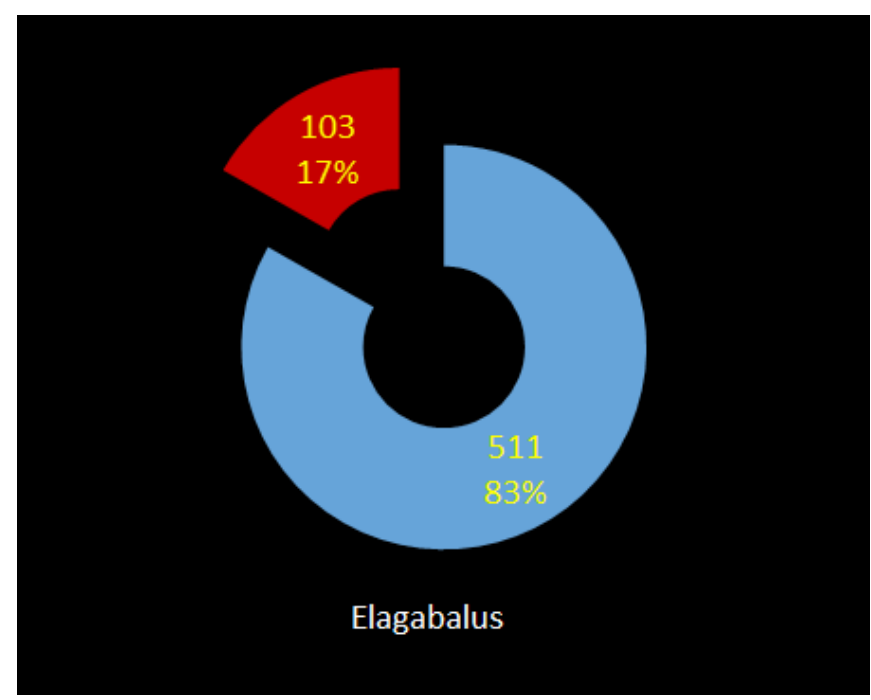

Fig. 148

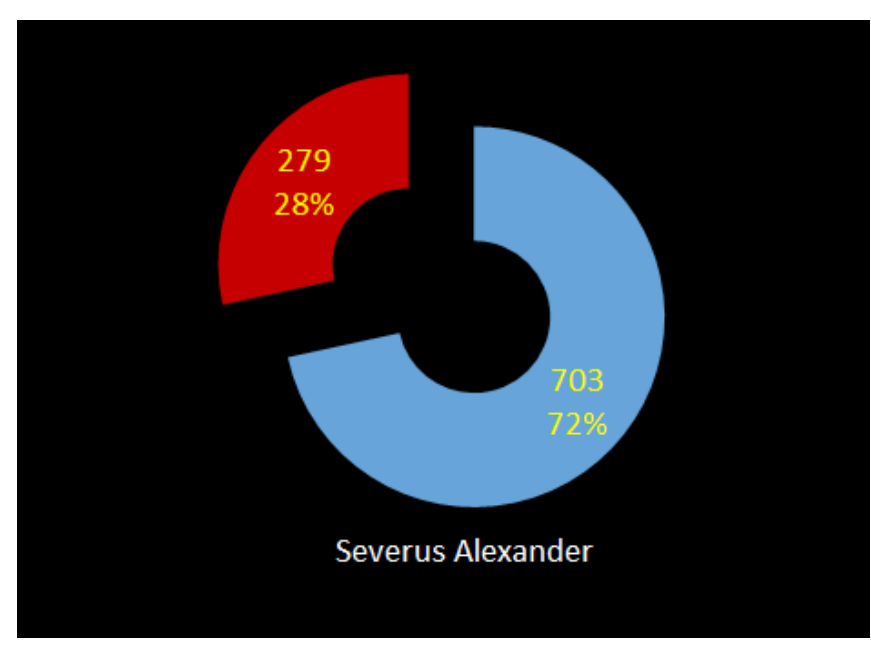

Fig. 149

Fig. 150, Fig. 151, Fig. 152 and Fig. 153 where the pie charts were placed on maps according to their location. This way it's possible to view the change in coin proportions during the Severian period (193-235) on different archaeological sites from East to West.

In Fig. 150 regarding the time frame of Septimius Severus (193-211) we can see sites numbered from 1 to 5 for sites located in Roman Dacia, Porolissum with 156 plated silver coins representing $62 \%$ of the total, Arcobadara with 37 plated silver coins representing 49\%, Potaissa with 34 plated and cast silver pieces representing 13\%, Apulum with 78 plated silver coins representing $54 \%$ and Ulpia Traiana Sarmizegetusa with 14 plated silver pieces representing $26 \%$.

Sites numbered from 6 to 9 are located in Roman Pannonia Inferior and Superior, Intercisa with 37 plated silver coins representing $49 \%$, Brigetio with 80 plated silver pieces representing $32 \%$ and Carnuntum with 384 plated silver coins representing $26 \%$.

Next follows Roman Noricum with sites numbered from 10 to 11, Vindobona with 51 plated silver coins representing $42 \%$ and Ovilava with 13 plated silver pieces representing $19 \%$. Roman Raetia is shown in sites numbered from 12 to 14 , Castra Regina with two plated silver coins representing $11 \%$, Eining with four plated silver coins representing $11 \%$ and Augusta Vindelicorum with one plated silver coin representing $6 \%$.

Towards to the west we have Roman Germania Superior with sites numbered from 15 to 18, Nida with 13 silver plated coins representing 13\%, Mogontiacum with 14 silver plated pieces representing 16\%, HofheimMain-Taunus with three plated silver coins representing $6 \%$, Zugmantel with 30 plated silver coins that represent $15 \%$ and for Roman Gallia Belgica site number 19, Augusta Treverorum with three plated pieces representing $3 \%$.

We can observe that when going westwards, the percentage for plated coins is decreasing. Thus, for Porolissum $62 \%$ are plated coins, Arcobadara with $49 \%$, Potaissa with $13 \%$, Apulum with 54\%, Ulpia Traiana Sarmizegetusa with $26 \%$, Intercisa with $49 \%$, Brigetio with $32 \%$, Carnuntum with $26 \%$, Vindobona with $42 \%$, Ovilava with $19 \%$, Castra Regina with $11 \%$, Eining with $11 \%$, Augusta Vindelicorum with $6 \%$, Nida with $13 \%$, Mogontiacum with $16 \%$, Hofheim Main Taunus with 6\%, Zugmantel with 15\%, Augusta Treverorum with 3\%.

Fig. 151 represents the coins situation during the reign of Caracalla (211-217), same as before we have sites from 1 to 5 for Dacia, Porolissum with 27 silver plated pieces representing 51\%, Arcobadara with three silver plated coins representing 38\%, Potaissa with 18 silver plated and cast pieces representing 34\%, Apulum with 20 silver plated coins representing 69\% and Ulpia Traiana Sarmizegetusa with four silver plated coins representing $36 \%$.

Sites numbered from 6 to 9 represent locations from Roman Pannonia Inferior and Superior, Intercisa with three silver plated coins representing 38\%, Gorsium-Herculia with two silver plated pieces representing $12 \%$, Brigetio with 34 silver plated coins representing $42 \%$ and Carnuntum with 41 silver plated coins representing 32\%.

For Roman Noricum, we have sites numbered from 10 to 11 , Vindobona with 14 silver plated coins representing $67 \%$ and Ovilava with three silver plated coins representing 15\%. Also for Roman Raetia there are the following sites numbered from 12 to 14, Eining with one silver plated coin representing $8 \%$ and Augusta Vindelicorum with one silver plated coin representing $25 \%$.

In Roman Germania Superior, we have sites numbered from 15 to 18 , Nida with eight plated silver coins representing 21\%, Mogontiacum with one silver plated coin representing $25 \%$ and Zugmantel with four silver plated coins representing 20\%. At the end, we also have site number 19 for Gallia Belgica, Augusta Treverorum with one silver plated coin representing $4 \%$.

For this time frame, the percentage of silver plated coins has increase since the previous issuer, Porolissum with $51 \%$, Arcobadara with 38\%, Potaissa with 34\%, Apulum with 69\%, Ulpia Traiana Sarmizegetusa with $36 \%$, Intercisa with $38 \%$, Gorsium-Herculia with $12 \%$, Brigetio with $42 \%$, Carnuntum with 95\%, Vindobona with $67 \%$, Ovilava with $15 \%$, Eining with $8 \%$, Augusta Vindelicorum with 25\%, Nida with 21\%, Mogontiacum with 25\%, Zugmantel with $20 \%$, Augusta Treverorum with $4 \%$.

Fig. 152 represents the situation during the reign of Elagabalus (218-222), we have the sites from 1 to 5 for Dacia, Porolissum with 15 plated silver coins that represent 29\%, 


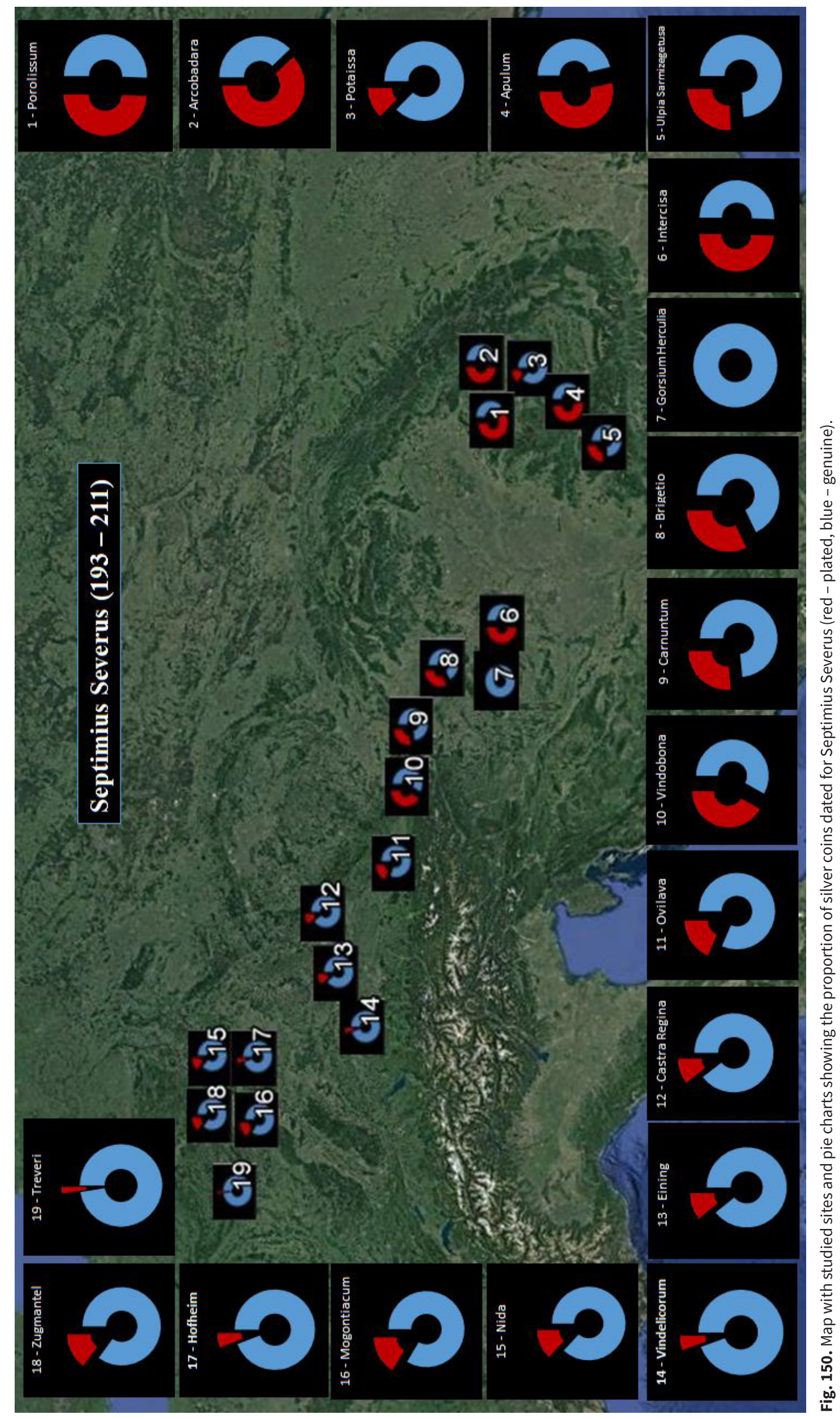

$$
\text { . }
$$

(1)

( 


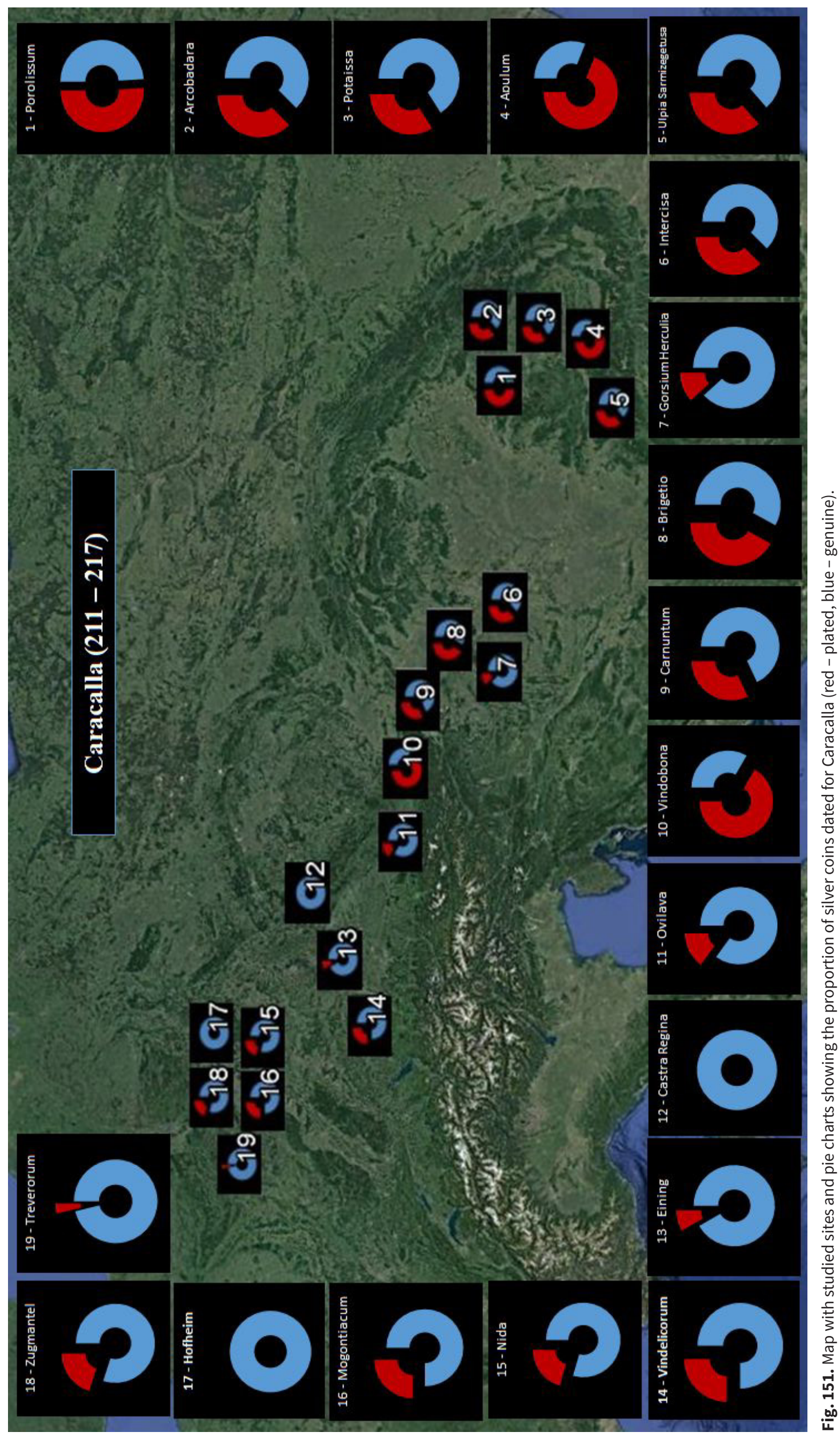


Arcobadara with four silver plated coins representing 33\%, Potaissa with eight silver plated and cast pieces representing 9\%, Apulum with 37 silver plated coins representing 51\% and Ulpia Traiana Sarmizegetusa with two silver plated pieces representing 11\%. The sites numbered from 6 to 9 are located in Pannonia Inferior and Pannonia Superior, Intercisa with four silver plated pieces representing 33\%, Brigetio with 20 silver plated coins representing $16 \%$ and Carnuntum with 103 silver plated pieces representing $17 \%$.

Next follows Noricum with sites numbered from 10 to 11 , Vindobona with four silver plated coins representing $21 \%$ and Ovilava with three silver plated pieces representing $10 \%$. For Raetia we have sites from 12 to 14 only at Augusta Vindelicorum there have been identified two silver plated coins representing $18 \%$.

Regarding Germania Superior we have the following sites numbered from 15 to 18 , Nida with two silver plated coins representing $3 \%$, Mogontiacum with three silver plated pieces representing $8 \%$, Hofheim Main Taunus with two silver plated coins representing 7\%, Zugmantel with five silver plated pieces representing 7\%. Also, we have number 19 regarding Augusta Treverorum with two silver plated coins representing $3 \%$.

During the reign of Elagabalus (218-222) the proportion of silver plated coins decreases in value but it's very easy to see how there are larger proportions of this type of coin found in the eastern side of the studied area. Thus, for this study case we have Porolissum with 29\%, Arcobadara with 33\%, Potaissa with 9\%, Apulum with 51\%, Ulpia Traiana Sarmizegetusa with $11 \%$, Intercisa with $33 \%$, Brigetio with $16 \%$, Carnuntum with $17 \%$, Vindobona with $21 \%$, Ovilava with $10 \%$, Augusta Vindelicorum with $18 \%$, Nida with $3 \%$, Mogontiacum with $8 \%$, Hofheim Main Taunus with 7\%, Zugmantel with 7\%, Augusta Treverorum with 3\%.

Fig. 153 serves as representation for the situation dated at Severus Alexander (222-235) where we can observe the same layout as before, sites numbered from 1 to 5 for Dacia, Porolissum with 37 silver plated coins representing $33 \%$, Arcobadara with 11 silver plated pieces representing $31 \%$, Potaissa with 25 silver plated coins representing 13\%, Apulum with 66 silver plated pieces representing $49 \%$ and Ulpia Traiana Sarmizegetusa with eight silver plated coins representing 18\%. Sites numbered from 6 to 9 are in Pannonia Inferior and Pannonia Superior, Intercisa with 11 silver plated coins that represent $31 \%$, Gorsium-Herculia with two silver plated coins that represent $5 \%$, Brigetio with 69 silver plated coins that represent $29 \%$ and Carnuntum with 279 silver plated coins that represent $28 \%$.

Roman Noricum follows up with sites numbered from 10 to 11, Vindobona with nine silver plated coins representing 33\%, Ovilava with seven silver plated coins representing $10 \%$, and Roman province of Raetia with sites numbered from 12 to 14, Castra Regina with one silver plated piece representing 5\%, Augusta Vindelicorum with two silver plated pieces representing $12 \%$.

For the Roman province of Germania Superior there are the sites numbered from 15 to 18 , Nida with 14 silver plated coins which represent $11 \%$, Mogontiacum with nine silver plated pieces that represent $13 \%$, Hofheim Main Taunus with two silver plated coins that represent $4 \%$ and
Zugmantel with ten plated silver coins that represent $8 \%$.

Thus, the largest proportion of plated coins are found on eastern studied sites, Porolissum with $33 \%$, Arcobadara with $31 \%$, Potaissa with $13 \%$, Apulum with $49 \%$, Ulpia Traiana Sarmizegetusa with $18 \%$, Intercisa with $31 \%$, Gorsium-Herculia with 5\%, Brigetio with 29\%, Carnuntum with $28 \%$, Vindobona with $33 \%$, Ovilava with $10 \%$, Castra Regina with 5\%, Augusta Vindelicorum with $12 \%$, Nida with $11 \%$, Mogontiacum with 13\%, Hofheim Main Taunus with $4 \%$, Zugmantel with $8 \%$.

It's easy to observe the difference in percentage for plated silver coins when it comes to eastern sites and western sites, settlements located in different Roman provinces and pieces used over the time of a dynasty.

During the reign of Septimius Severus (193-211) on sites located in Dacia there have been discovered silver plated coins which form up between $13 \%$ to $62 \%$ of the total number of identified coins on the sites, depending on the location, in Pannonia between $26 \%$ to $49 \%$, Noricum between $19 \%$ and $42 \%$, Raetia between $6 \%$ and $11 \%$ and Germania Superior with Gallia Belgica between 3\% and 16\%.

Later during the reign of Caracalla (211-217), we have the next values regarding the proportions for silver plated pieces, Dacia between $34 \%$ and $69 \%$, Pannonia between $12 \%$ and $42 \%$, Noricum between $15 \%$ and $67 \%$, Raetia with proportions between $8 \%$ and $25 \%$, Germania Superior and Gallia Belgica between $4 \%$ and $25 \%$.

For the time frame of Elagabalus (218-222) the following proportions have been recorded regarding the plated coins in studied regions, Dacia between $9 \%$ and $51 \%$, Pannonia between $16 \%$ and $33 \%$, Noricum between $10 \%$ and $21 \%$, Raetia with 18\%, Germania Superior and Gallia Belgica between $3 \%$ and $8 \%$.

During the reign of Severus Alexander (222-235) on the sites from Dacia there have been identified between $13 \%$ to $49 \%$ silver plated coins, in Pannonia between $5 \%$ and $31 \%$, for Noricum between $10 \%$ and $33 \%$, Raetia between $5 \%$ and $12 \%$ while in Germania Superior and Gallia Belgica between $4 \%$ and $13 \%$.

Thus, while in Germania Superior during the Severian dynasty the proportions for silver plated pieces oscillate between $5 \%$ and $20 \%$ or $25 \%$ and in Raetia between $5 \%$ and 20\%, in Pannonia the proportion for silver plated pieces move between $5 \%$ and $49 \%$ while in Dacia between $9 \%$ and $69 \%$.

It's highly possible that increase proportions of silver plated pieces discovered for Pannonia and Dacia suggest a mixt monetary distribution for frontier provinces located on the border of the empire. This may explain the visible predisposition for distributing more genuine pieces towards the Rhine frontier than its Danube counterpart which shows rich proportions of silver plated pieces.

\section{INTERPRETATIONS}

After each studied region was presented with its number of genuine and plated coins, it was time to compare the regions between themselves and with those located on the Middle Danube, Roman provinces of Pannonia Superior, Pannonia Inferior and Dacia. 


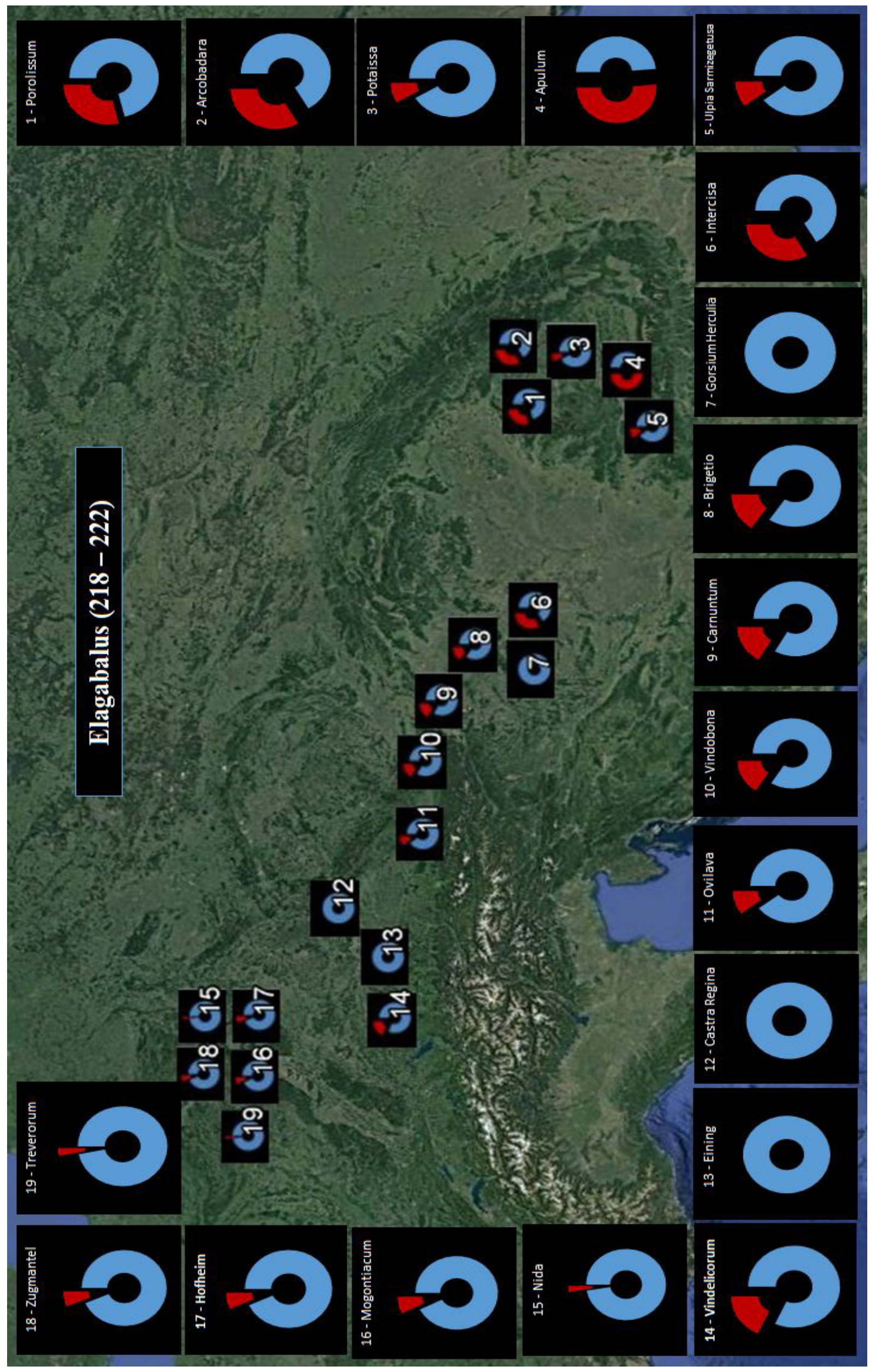

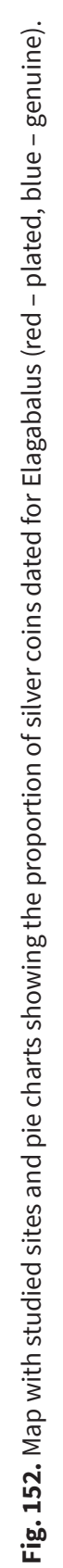




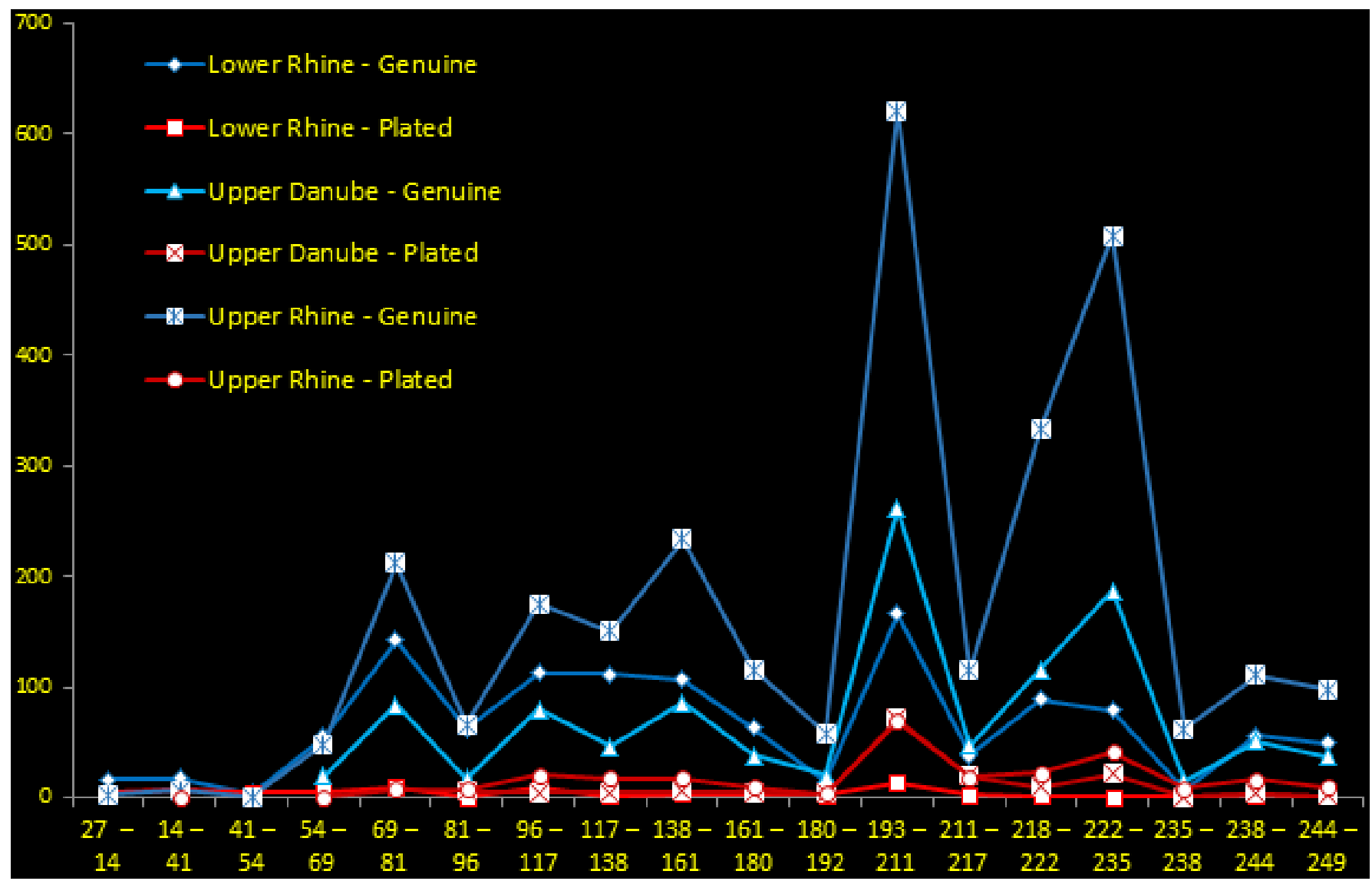

Fig.154. Numbered of genuine and plated silver coins on studied regions.

We can straightforward observe the sparse number of : of Fig. 154 we can observe the scale for quantity of pieces. plated pieces discovered for these regions, on the left side : Even if plated coins have been identified using images dated

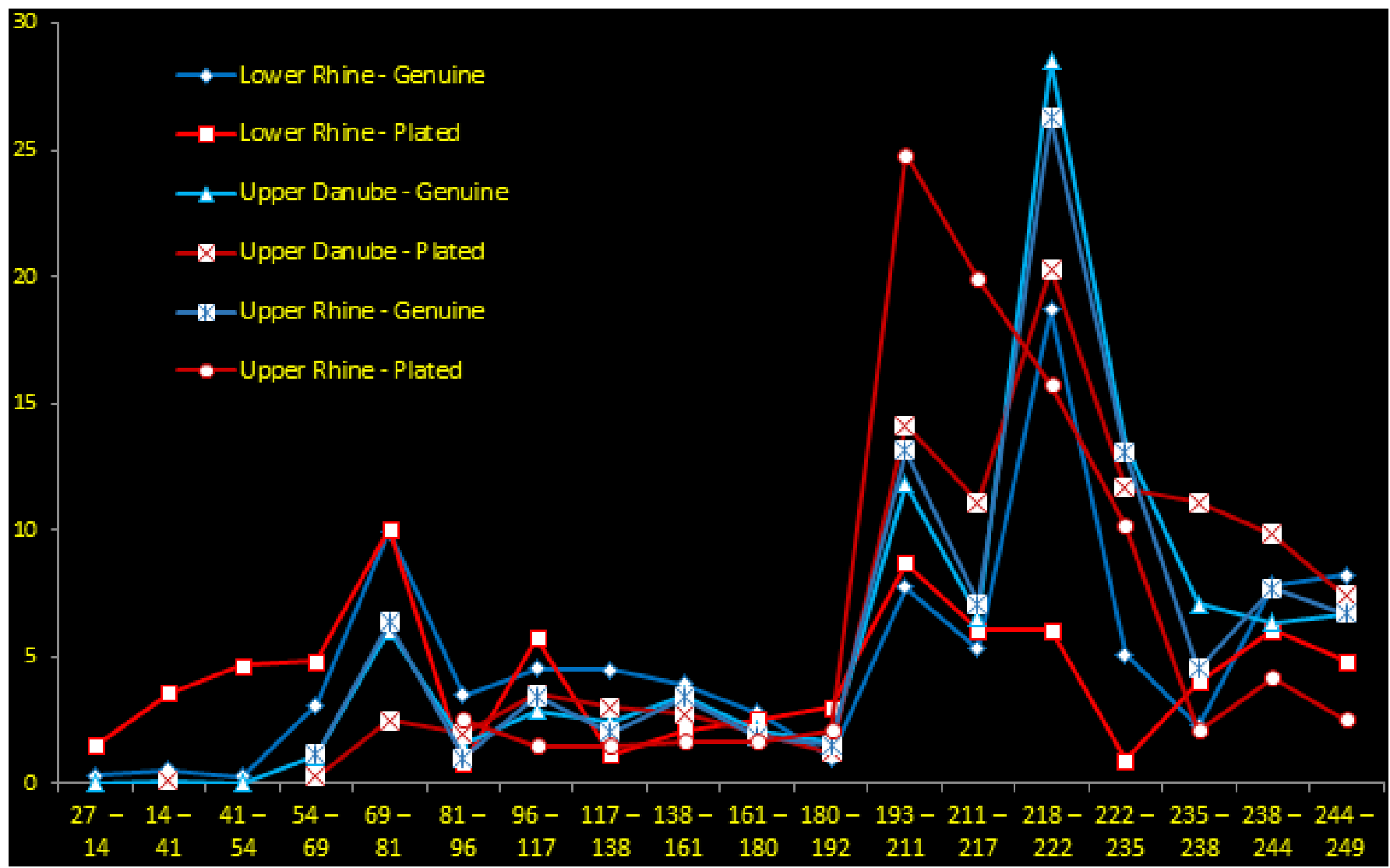

Fig.155. Coefficient of genuine and plated silver coins on studied regions. 


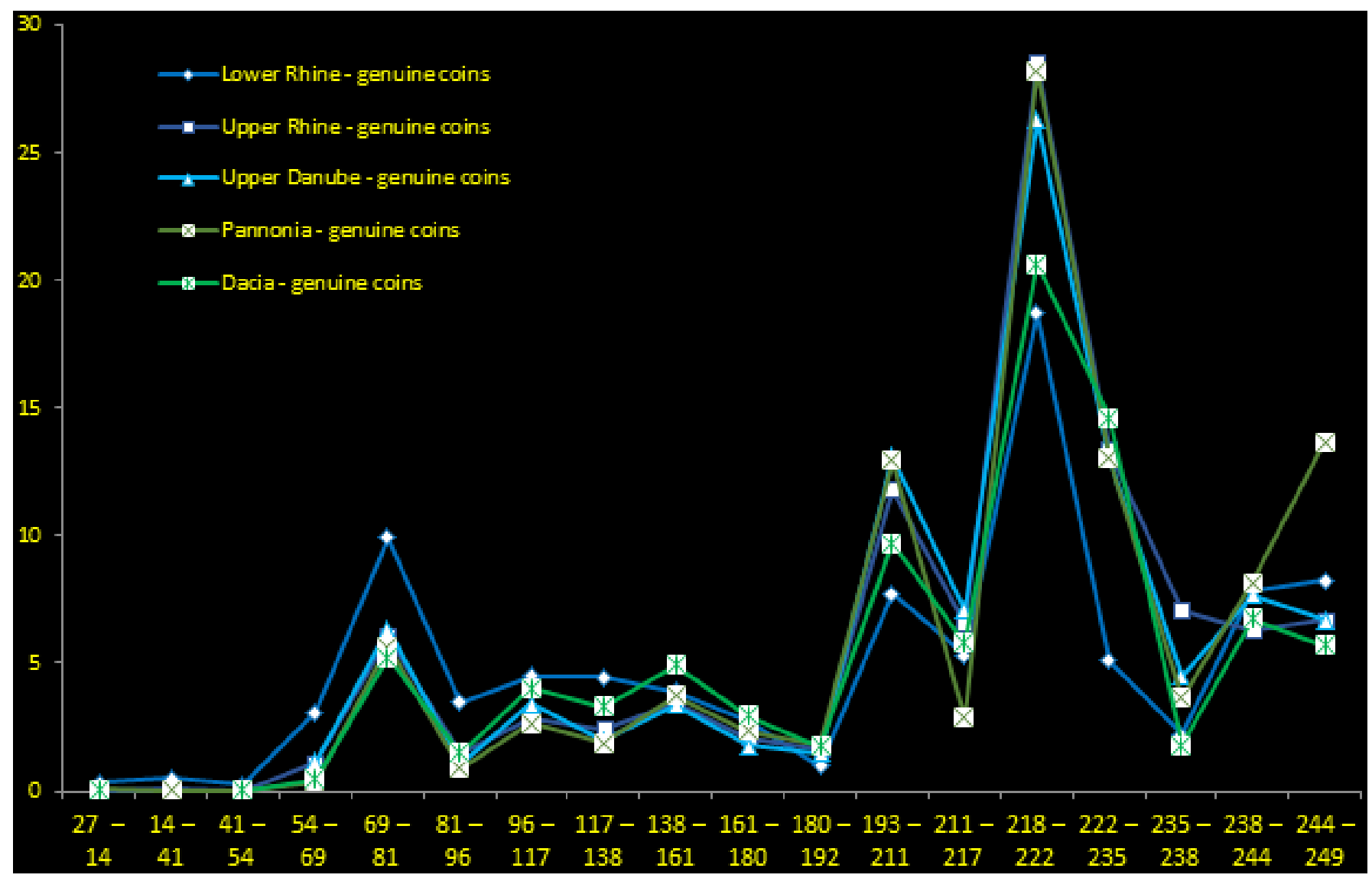

Fig.156. Coefficient of genuine silver coins - Rhine vs. Danube.

anywhere from Augustus (27BC-14AD) to Philip I (244-249) most coins have been dated during the Severian dynasty (193-235).

In the case of genuine pieces, we can see the substantial number of dated pieces between $69-81$ and the decrease of genuine pieces dated between 81-96. For the Antoninian period the index for genuine pieces increase and stays at a steady rhythm until the reign of Commodus (180192) when all index decrease.

Next follows the Severian period, for Septimius Severus (193-211) the index will increase very much while for Caracalla (211-217) they will decrease but increase again for Elagabalus (218-222) and Severus Alexander (222-235). With the beginning of Military Anarchy, all index decrease in value a smaller increase being recorded for Gordian III (238244) and Philip I (244-249).

Thus, we observe how the pattern of coin circulation for genuine pieces regarding these regions is most of the times identical with that of individual studied sites as seen in Fig. 65, Fig. 68 and Fig. 71.

In Fig. 155 on the other hand we can see the index for silver coins using the Ravetz ${ }^{158}$ formula. Because this formula works at its best only when using large quantities of coins and in order to reach accurate results this method was not used for individual sites just at regional level.

Coefficients for genuine pieces show very similar patterns during same historical periods, on the other side coefficients for plated pieces show different results.

First of all, the index for Lower Rhine region shows very high values during the first eight decades of the I 158 CASEY 1974, 41. century but during Vespasian (69-79) all plated coefficients increase in value, followed by a decrease during Domitian (81-96) and a steady rhythm during the Antoninian period.

During the Severian period all coefficients for plated pieces increase in value, under Septimius Severus (193-211) and Caracalla (211-217) the index for plated coins is equal or higher in value with that of genuine pieces, for Elagabalus (218-222) the genuine coefficient is higher than that of plated pieces and during Severus Alexander (222-235) index for plated coins decreases in value but have similar levels with coefficients for genuine coins.

These results are not enough however for a comparative view along the Roman frontier, that's why new graphs were formed by merging the results regarding coin coefficients at regional level from Germania Inferior, Gallia Belgica, Germania Superior, Raetia and Noricum with results from Pannonia Superior, Pannonia Inferior and Dacia ${ }^{159}$.

Fig. 156 presents coefficients for genuine pieces discovered on these regions, making it very easy to view the coin distribution in the area. The followed pattern is effortless to distinguish, low values during the first half of the I century followed by an increase in value during Nero (54-68) and civil war of 69, the increase continues during Vespasian (69-79) and Titus (79-81). The highest index is the one for Lower Rhine region which is very influenced by Roman sites of Nijmegen ant Trier which have massive quantities of silver coins dated during Vespasian (69-79).

For Domitian's period (81-96) coin coefficients decrease in value but during the Antoninian period they will increase again and maintain their rhythm. During 159 GASPAR 2015. 


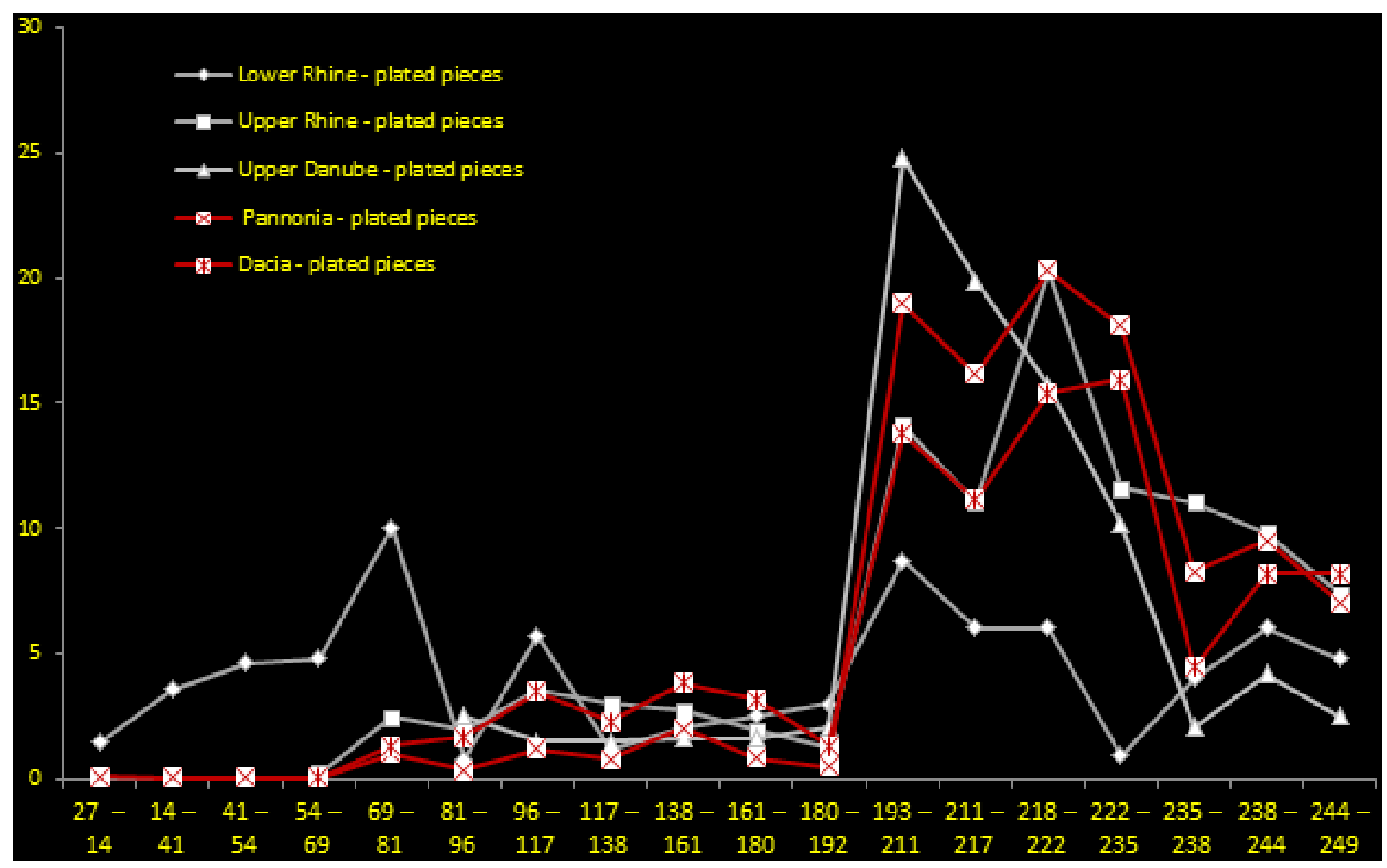

Fig.157a. Coefficient of plated silver coins - Rhine vs. Danube.

Commodus (180-192) all index decrease again but for Septimius Severus (193-211) an increase of about twice and a half in value, comparative to Antoninian values, is recorded for all coefficients.

During Caracalla (211-217) coefficients decrease again, under Elagabalus (218-222) however the index show a new increase between 4 to 6 times higher in value than the one dated during the Antoninian times. With Severus Alexander (222-235) a new decrease in value begins and will continue for Maximinus Thrax (235-238) as well.

For the beginning of Military Anarchy under Gordian III (238-244) and Philip I (244-249) index increase again in value.

It's plain simple to observe the pattern of coin distribution for genuine pieces for areas located on the empires border, even if we discuss about Dacia which was incorporated in $106 \mathrm{AD}$, of Noricum which is acquired during Claudius (41-54) ${ }^{160}$ or Germania Superior which is extended during the Flavian dynasty. One of the reasons why coefficients for genuine pieces have such high values dated during Vespasian (69-79) is because during his son Domitian (81-96) ${ }^{161}$ a monetary reform took place, old coins up to him being melted and reminted with his image ${ }^{162}$, highly unlikely of him to melt coins issued by his own father.

Next follows the times of stability and prosperity attributed to Antoninian rulers, the decrease in value during Commodus (180-192) and high quantities of coins being issued during Severian times, especially Septimius Severus

\footnotetext{
160 FISCHER 2002, 21.

161 HARL 1996, 14.

162 JONES 1992, 76.
}

(193-211) when the silver coinage is debased ${ }^{163}$, old pieces are melted and reissued under his image and his percentage of silver.

In Fig. 157 we can see the distribution of silver plated pieces regarding the studied area. In some places like Pannonia or Germania Inferior these pieces arrive even from Augustus's times because of the early Roman presence in the area. On the other hand, in Germania Superior plated coins arrive most likely only with the start of the Flavian dynasty, while in Dacia after Trajan (98-117) conquest. Unfortunately, since we can't calculate the time of circulation for a Roman coin the only timeframe that we have is the terminus post quem, more exactly the date at which the genuine image was issued.

Most coefficients for plated pieces increase in value during Vespasian (69-79), this is because of his son Domitian (81-96) and his monetary reform which melted and reissued older coins, which can also explain the low values for plated coins before Vespasian since not many genuine models were left to use for plating them.

On the other hand, the index regarding Germania Inferior shows high values even before Vespasian (69-79). This is because of Nijmegen, where most silver coins were dated during the I century $\mathrm{AD}$ and there were many silver plated pieces identified alongside the genuine ones.

Thus, after using the Ravetz formula at regional level and because in total only 83 plated coins were identified for this area, the coefficient is very high in value. This is not wrong from the historical point of view but it does influence the way that plated pieces are represented in graphs.

During the Antoninian period the coefficient for plated 163 DEPEYROT 2006, 126. 


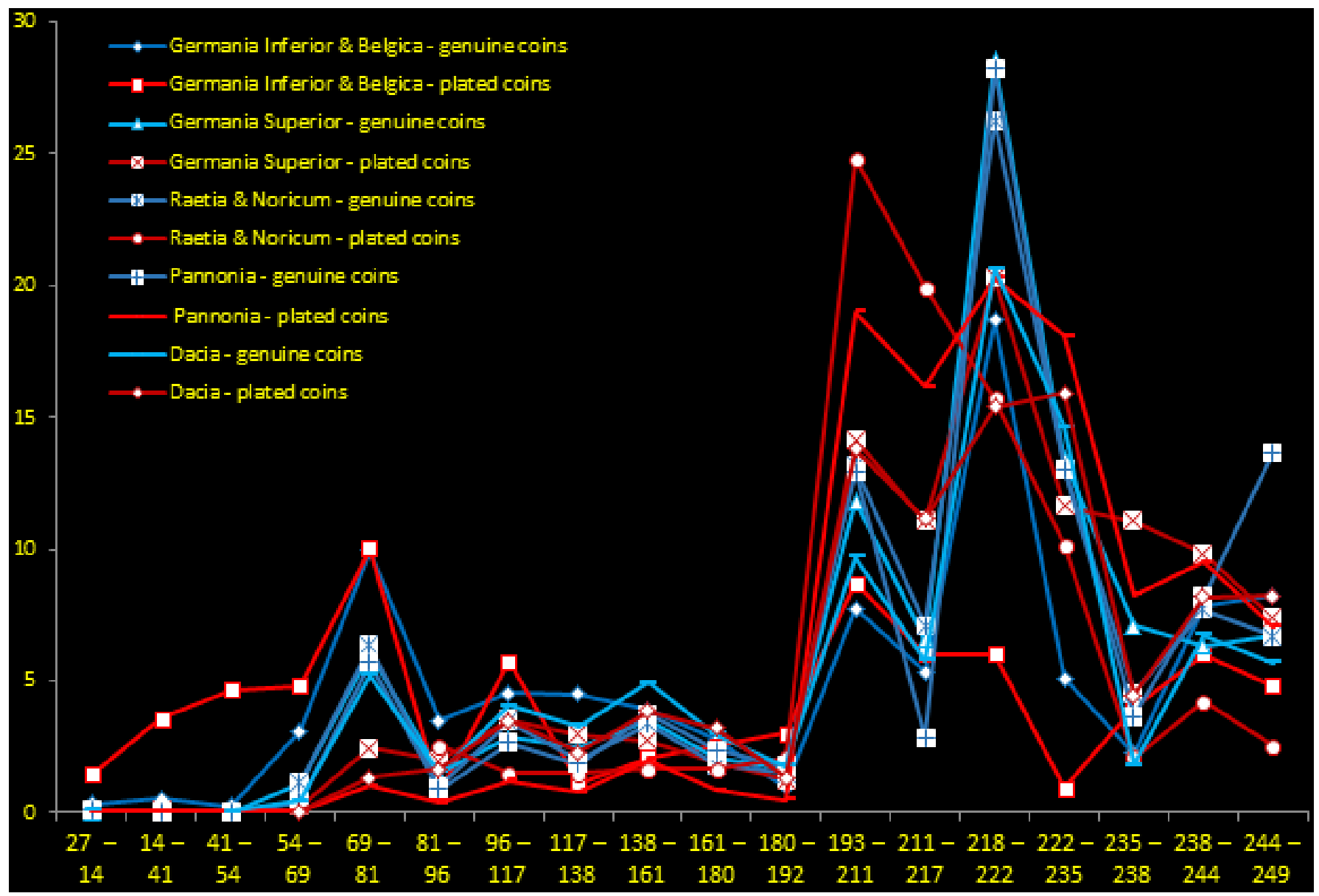

Fig.157b. Coefficient of genuine and plated silver coins - Rhine vs. Danube.

pieces maintains a steady rhythm which at the beginning of the Severian period will increase between 3 to 5 times in value. With the start of Military Anarchy, the index will decrease and maintain a new level.

In the case of Lower Rhine region, we can observe that it has the lowest value regarding plated pieces dated during the Severian dynasty. This is because the few plated coins discovered on sites from this area, the military camp from Nijmegen being abandoned during the reign of Hadrian (117-138) while the settlements from Nörvenich, Mariaweiler and city of Trier were all civilian areas.

Coefficients for Germania Superior, Upper Danube, Pannonia and Dacia show very high values which are typical when it comes to Severian dynasty and military areas, this timeframe represents the beginning of major debasements for silver coinage ${ }^{164}$.

After all these graphs, a new one was needed. Fig. 158 is the embodiment of the general situation for all the studied area, genuine and plated coin coefficients, so that we can observe the followed patterns by these coins. As we can see most of the time they followed a similar pattern during the I and II centuries, general increase in value for Severian dynasty and general decrease with Maximinus Thrax (235238) and Military Anarchy.

It is also possible to see particularities of the studies areas, for example how Germania Inferior has many identified plated pieces date during the Julio-Claudian and Flavian times but not the Severian period.

\footnotetext{
${ }_{164}$ DEPEYROT 2006, 126
}

Raetia and Noricum present the highest value for plated coins coefficients during the reign of Septimius Severus (193-211), value which decreases for the following issuers until Maximinus Thrax (235-238).

Highest values reached by plated coin coefficients during the reign of Septimius Severus (193-211) are those which represent Dacia, Pannonia, Noricum and Raetia, situation which remains the same during Caracalla (211217) as well.

On the other hand, during Elagabalus (218-222) the coefficients for genuine pieces regarding regions like Germania Superior, Noricum and Pannonia have higher values than any other index for this period. For Severus Alexander (222-235) the values start decreasing, only after Maximinus Thrax (235-238) the coefficients will increase in value again.

\section{PLATED COINS:}

After researching coin catalogs for pieces discovered along the German limes there have been found 5.212 genuine silver coins and 513 silver plated coins.

For Roman Noricum and Raetia, we have the site from Vienna where 66 silver plated coins which represent $24 \%$ were discovered as seen in Fig. 1 , at Wels there have been identified 41 silver plated pieces which represent $12 \%$ as seen in Fig. 3, for Straubing we have eight plated coins which represent $15 \%$ seen in Fig. 5, at Regensburg there have been discovered 10 silver plated pieces with $8 \%$ as per Fig. 7 , in the case of Pfunz four plated silver coins were identified 
seen in Fig. 9, Eining has nine silver plated coins with $5 \%$ as per Fig. 13 and Augsburg where six plated silver pieces were discovered and represent 5\% as seen in Fig. 15.

In the case of Germania Superior there are the following sites, Rottenburg am Neckar where two silver plated pieces were identified that represent $1 \%$ as seen in Fig. 19, Bad Cannstatt which has two silver plated pieces with $1 \%$ as per Fig. 21, Rheinzabern with one silver plated coin which represents $1 \%$ seen in Fig. 23, Speyer with one silver plated piece that represents $2 \%$ as seen in Fig. 25, Nida where 66 silver plated coins were identified representing $10 \%$ seen in Fig. 33, Rückingen with five silver plated pieces witch represent $11 \%$ as seen in Fig. 35, Friedberg where five silver plated pieces that represent $11 \%$ as seen in Fig. 37, Mainz where 44 silver plated coins where identified and represent $14 \%$ from the total number of coins on the site as seen in Fig. 39, Hofheim with 22 silver plated pieces that represent $10 \%$ as per Fig. 41, Wiesbaden which shows 15 silver plated coins with $12 \%$ as seen in Fig. 43 , Zugmantel where 66 silver plated coins were identified and represent $10 \%$ from the total number of coins as seen in Fig. 45, Heldenbergen where two silver plated coins where discovered that represent $3 \%$ as seen in Fig. 47, Ober-Florstadt with four silver plated coins that represent 5\% as per Fig. 49 and Butzbach with eight plated silver pieces that represent 7\% as seen in Fig. 51.

For Germania Inferior and Gallia Belgica we have the sites from Trier where 27 silver plated coins were discovered representing 4\% as seen in Fig. 53, Mariaweiler-Hoven where 13 silver plated pieces were identified representing $13 \%$ as seen in Fig. 55, Nörvenich where nine silver plated coins with $8 \%$ where discovered as seen in Fig. 57, Köln where three silver plated pieces with $3 \%$ were discovered as seen in Fig. 59, Neuss where eight silver plated coins that represent $14 \%$ were identified as seen in Fig. 61 and Nijmegen with 18 silver plated pieces that represent $11 \%$ as seen in Fig. 63.

Therefore, for Noricum silver plated pieces represent between $12 \%$ and $24 \%$, for Raetia between $5 \%$ and $15 \%$, in the case of Germania Superior between $1 \%$ and $14 \%$, for Germania Inferior between $3 \%$ and $14 \%$ and for Trier located in Gallia Belgica just 4\%.

We can see observe the decrease in proportions for plated silver pieces as the study moves westwards, in Noricum between $12 \%$ - $24 \%$ are plated pieces while for both German provinces only between $1 \%-14 \%$.

\section{HYBRID COINS:}

Hybrid coins are pieces that represent on their sides images originating from different types of coins or different issuers $^{165}$. Most of the times this happens because of human error during the minting process when a coin may get struck twice out of mistake or get struck with images from diverse issuers on its sides.

Authors of $\mathrm{RIC}^{166}$ have omitted these types of coins in their catalogues, without realizing that involuntary they made many future researchers to wrongly believe that all Roman coins issued by Roman authorities can be found in their catalogues ${ }^{167}$.

\footnotetext{
PREDA 2008, 151.

166 Roman Imperial Coinage.

167 MATTINGLY 1923-2007.
}

Back to hybrid pieces, for Roman Noricum there is Vienna showed in Fig. 2, there were discovered nine silver coins, six of them dated at Septimius Severus (193-211), one coin for Caracalla (211-217) and two coins during Philip I (244-249). For the site of Wels seen in Fig. 4 there were identified two coins, one dated during Antonius Pius (138161) and one during Septimius Severus (193-211).

For the province of Raetia, we have the following sites like Pfunz showed in Fig. 10 where one silver piece was dated for the reign of Septimius Severus (193-211). Eining seen in Fig. 14 with two hybrid coins, one dated at Septimius Severus (193-211) and one to Caracalla (211-217). Augsburg seen in Fig. 16 where one hybrid coin was detected for the reign of Gordian III (238-244).

In Germania Superior at Bad Cannstatt seen in Fig. 22 one hybrid coin was discovered that was dated at Hadrian (117-138). Rheinzabern represented in Fig. 24 with one hybrid coin dated for Caracalla (211-217). Nida represented in Fig. 34 with seven hybrid coins, one dated for Hadrian (117138), one for Antoninius Pius (138-161), one for Septimius Severus (193-211), one dated at Gordian III (238-244) and three pieces for Philip I (244-249). At Friedberg seen in Fig. 38 a hybrid coin was dated at Antonius Pius (138-161). At Mainz seen in Fig. 40 three coins were identified, two dated for Septimius Severus (193-211) and one for Caracalla (211-217). For Hofheim seen in Fig. 42 one hybrid coins was dated during Septimius Severus (193-211). At Zugmantel represented in Fig. 46 eight hybrid coins were identified, one for Marcus Aurelius (161-180), two for Septimius Severus (193-211), three for Caracalla (211-217) and two for Elagabalus (218222). For Ober-Florstadt seen in Fig. 50 only one hybrid coin was identified and dated at Gordian III (238-244) and in Butzbach represented in Fig. 52 also one hybrid coin was dated during Marcus Aurelius (161-180).

For Gallia Belgica and city of Trier seen in Fig. 54 seven hybrid coins were found, one dated for Domitian (81-96), one dated for Nerva (96-98), three for Septimius Severus (193-211), one for Caracalla (211-217) and one dated for Gordian III (238-244).

Regarding Germania Inferior we have the site from Köln seen in Fig. 60 where one hybrid coins discovered and dated at Tiberius (14-37) while at Neuss represented in Fig. 62 one hybrid coin was dated for Caracalla (211-217).

Alongside the genuine hybrid pieces found on these sites, which were issued by striking the image on the coin and were made with the consent of Roman authorities, there have been discovered hybrid silver plated pieces as follows.

For Noricum area, we have the site of Vienna seen in Fig. 2 where 18 silver plated hybrids were discovered, one coin dated at Hadrian (117-138), ten coins dated for Septimius Severus (193-211), five dated for Caracalla (211217), one piece dated for Elagabalus (218-222) and two coins dated for Severus Alexander (222-235). For the site located at Wels showed in Fig. 4 there were identified four silver plated hybrid coins, two dated for Domitian (81-96), one for Marcus Aurelius (161-180) and one for Septimius Severus (193-211).

In the case of Roman Raetia, we have the site from Regensburg seen in Fig. 8, where one silver plated hybrid was discovered and dated during the reign of Gordian III (238- 


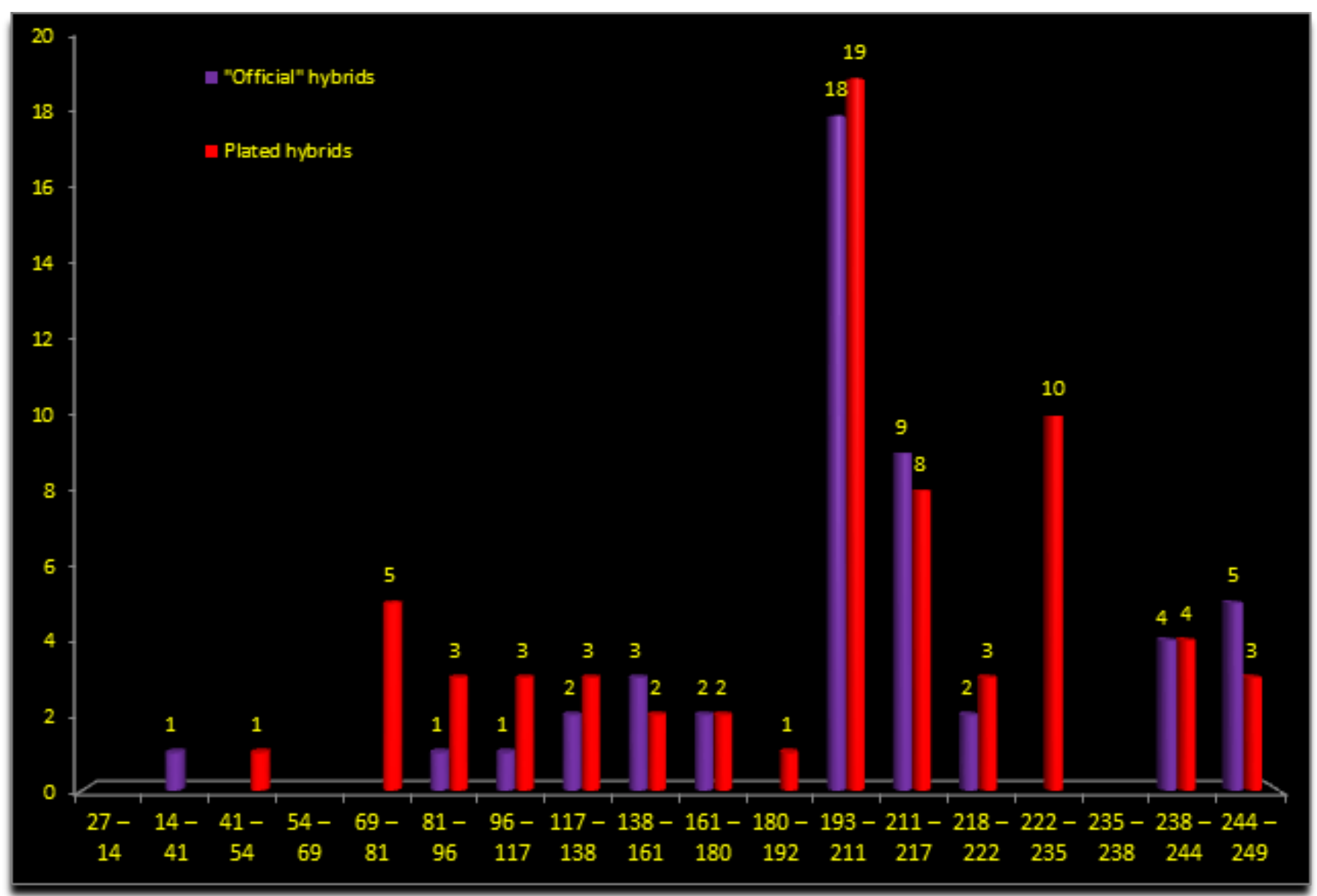

Fig. 158. Graph with number of silver hybrid pieces discovered along the Germanic limes.

244).

Regarding Germania Superior we have a few sites where silver plated hybrids were discovered. Nida seen in Fig. 34 has four silver plated hybrids, one dated for Hadrian (117-138), one for Caracalla (211-217) and two for Severus Alexander (222-235). Mainz seen in Fig. 40 shows nine pieces, one dated for Domitian (81-96), one piece dated for Hadrian (117-138), five coins dated during Septimius Severus (193-211), one piece at Caracalla (211-217) and one for Severus Alexander (222-235). Hofheim seen in Fig. 42 has five silver plated hybrids, one dated for Titus (79-81), one for Septimius Severus (193-211), one coin dated at Elagabalus (218-222), one dated for Severus Alexander (222235) and one hybrid plated coin dated at Philip I (244-249).

For Roman fort of Zugmantel seen in Fig. 4616 hybrid plated coins were identified, one dated for Trajan (98-117), one coin for Antonius Pius (138-161), another coin dated during Marcus Aurelius (161-180), one coin dated during Commodus (180-192), two pieces dated for Septimius Severus (193-211), one coin dated for Caracalla (211-217), another piece dated for Elagabalus (218-222), three hybrid plated coins dated for Severus Alexander (222235), two for Gordian III (238-244) and three hybrid pieces for Philip I (244-249). At Butzbach seen in Fig. 52 only one plated hybrid coin was discovered and dated for Hadrian (117-138).

For city of Trier represented in Fig. 54, four hybrid plated silver coins were discovered, one with images dated at Claudius (41-54), one for Trajan (98-117), one at Gordian III
(238-244) and one piece for Philip I (244-249).

Roman Köln seen represented in Fig. 60 has only one hybrid plated silver coin dated at Vespasian (69-79). At Neuss seen in Fig. 62 two coins were discovered, one dated at Trajan (98-117) and one for Severus Alexander (222-235). Finally, we have the site from Nijmegen seen in Fig. 64 where three silver plated hybrids were discovered and dated during the reign of Titus (79-81).

All these intricate details regarding where and when hybrid coins and hybrid plated pieces where discovered was compiled and represented in Fig. 158. It's important to remember that these coins were discovered in same conditions as genuine pieces and only historical information that we can extract from them is the terminus post quem. It is possible to date the images represented on these pieces but not the date when there were issued.

Hybrid genuine coins, which were struck and made under the supervision of Rome remain as "official" pieces because of their parentage, on the other hand hybrid plated pieces are just counterfeited coins.

Looking at Fig. 158 we can observe that this type of coins was discovered for most reigns, most of them being dated during the time of the Severian dynasty, most notable for Septimius Severus (193-211), Caracalla (211-217) and Severus Alexander (222-235).

There were some hybrid pieces dated during the Antoninian period which reign is considered the Golden Age of Rome, because of the long stability and prosperity for the empire. 


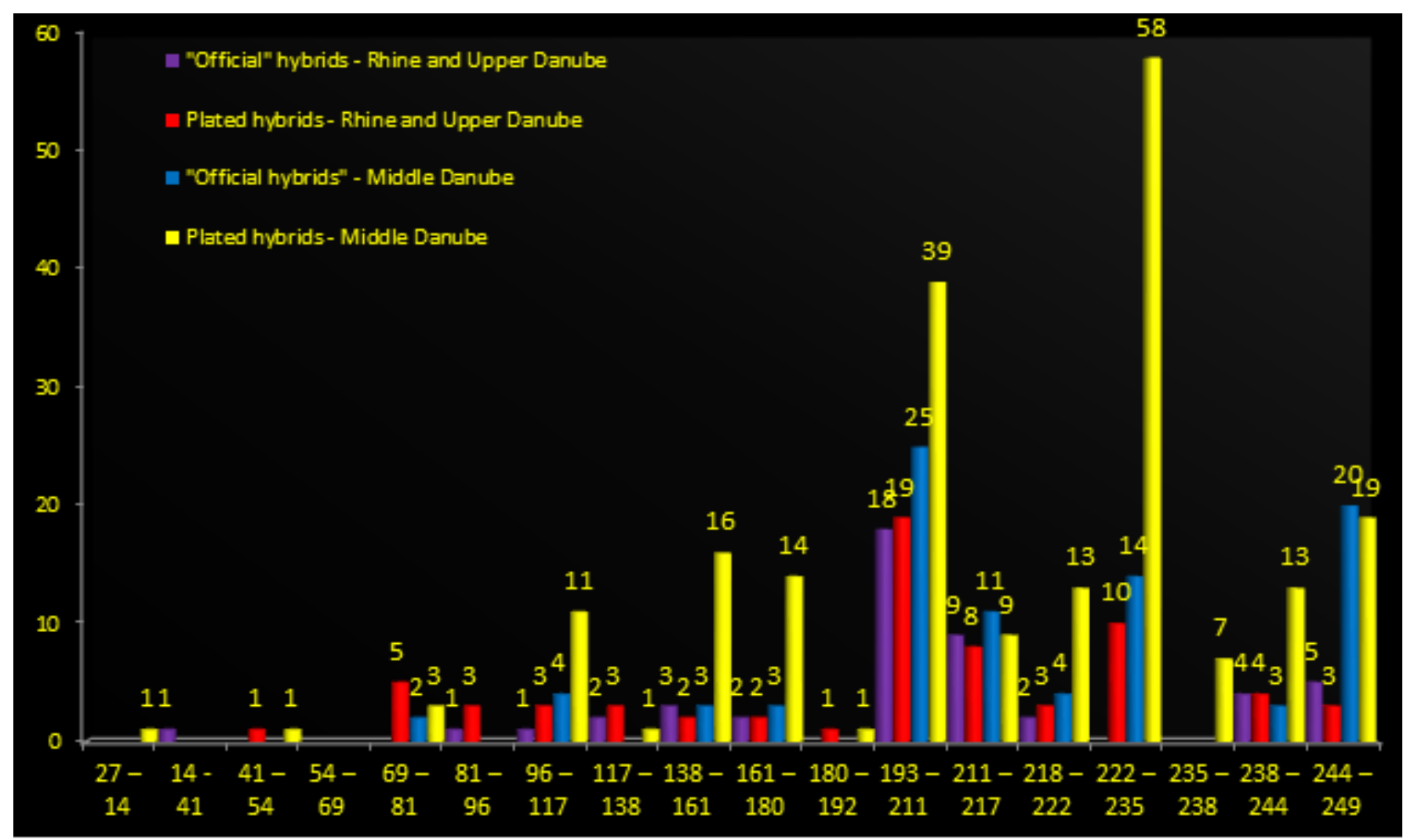

Fig. 159. Graph with number of silver hybrid pieces discovered along Germanic Limes vs. Dacia and Pannonia.

Without doubt, most silver plated coins dated during the I and II centuries were created during the Severian dynasty and Military Anarchy with the purpose of imitating older coins which in the collective knowledge and in fact did contain higher quality of silver. Without knowing the story behind hybrid pieces, those who manufactured and reproduced hybrid coins in plated form actually used for models pieces which already had some fabrication errors on them. Even if this is the case, silver plated hybrid pieces are nothing more than plated coins.

For comparing the situation for Rhine and Upper Danube region with that for Middle Danube, formed by Dacia and Pannonia, a final graph was made seen in Fig. 159 that represents the distribution of hybrid coins, genuine and plated pieces.

Represented in blue and yellow, the region of Middle Danube shows that more pieces have been discovered here that along the German Limes, seen in red and purple. Most of the pieces have represented on them images dated back during the reign of Septimius Severus (193-211) and Severus Alexander (222-235).

Also for Middle Danube region we can see higher values for plated coins dated during Trajan (98-117), Antonius Pius (138-161), Marcus Aurelius (161-180), Gordian (238-244) and Philip I (244-249).

From 5.725 silver coins identified along the German Limes area and used for this study, only 48 are genuine hybrids and 67 are plated hybrids which in total represent between $1-2 \%$ of the total number of silver coins. This case is similar with the one for Pannonia and Dacia where same percentage values were identified ${ }^{168}$.

\footnotetext{
168 GASPAR 2015.
}

Even so, no matter the number of discovered hybrid coins and plated hybrid piece, they continue to be a special chapter in the books of numismatics because of their originality and peculiarity.

\section{CONCLUSIONS:}

Besides the initial seven studied sites located in Dacia and nine sites from Pannonia an additional two sites from Noricum, seven locations from Raetia, 17 sites from Germania Superior, four locations from Germania Inferior and one for Gallia Belgica were added with the reason of expanding the studied area.

In the case of genuine coins, as we have seen in Fig. 156, there is a visible pattern followed by coins in their distribution on the frontier, regardless if the province is Dacia, Noricum or Germania Inferior the pattern stays the same.

It's very clear that a continuous distribution and a followed pattern existed when discussing about genuine pieces issued by Roman authorities and delivered on the studied sites. The coefficients for genuine pieces follow this pattern with few changes depending on region and local particularities. We can observe the lack of silver coins dated before the Flavian period because of the monetary reform made by Domitian ${ }^{169}$ and the debasement of silver in coins ${ }^{170}$. Also, the lower quantity of coins discovered during Domitian reign can be explained by the next monetary reform made by Trajan when the quality of silver is again debased ${ }^{171}$ and many old pieces are melted. In same circumstance coins dated to

\footnotetext{
HARL 1996, 14.

170 JONES 1992, 76.

171 CRAWFORD 1978, 152. HARL 1996, 92-93.
} 
Flavian period were left in circulation because the quality of silver was already debased during Domitian's rule, comparable situation happening during Mark Antony's times ${ }^{172}$.

Next follows the Antoninian period with a steady rhythm for genuine pieces, being a well-known time of peace and prosperity for the whole empire, only at the end of this period during the reign of Commodus the coefficients decrease in value because of fewer issued coins ${ }^{173}$.

The Severian dynasty is characterized by very large quantities of issued pieces, because of silver debasement and the need to pay the military troops which were promised and received higher pays with the reign of Septimius Severus and Caracalla ${ }^{174}$.

Silver plated coins generally follow same patterns as genuine pieces, we can observe in Fig. 157 and Fig. 158, even surpass in value the coefficients for genuine coins during the Severian dynasty.

Besides the general pattern followed by silver plated coins which we have seen on many sites, a new particularity was observed during the case study on the Severian period as seen in Fig. 150, Fig. 151, Fig. 152 and Fig. 153. Thus, while in Germania Superior the percentage of silver plated coins wavers between 5\% and 20\%-25\% and in Raetia between 5\% and $20 \%$, in Pannonia this proportions are closer to $5 \%$ and $49 \%$ while in Dacia between $9 \%$ and $69 \%$.

It's very clear that there is a difference between the influx of silver coins across the frontier, sites from Middle Danube being supplied with higher quantities of silver plated pieces. On the other side because of the recent discoveries from Mogontiacum ${ }^{175}$, Potaissa ${ }^{176}$ or Apulum ${ }^{177}$, there is a higher chance that many silver plated pieces were produced close to these military centers.

Although the idea that specific individuals were behind the manufacturing of plated silver coins is not yet dismissed, the substantial number of plated pieces can only mean that a centralized power could be responsible for this ${ }^{178}$. The necessity of maintaining a large and permanent army which was promised higher payments started to undermine the empires economy, not because of the enormous number of coins needed to make the payments but because of a lack in precious metal to maintain the demand for silver.

In these circumstances, even if counterfeiting coins was severely punishable by law ${ }^{179}$, the massive quantities of plated pieces and recent discovered of hoardings made entirely of plated pieces with fabrication errors points us to the existence of a serial production for this type of coins, Roman authorities being most likely informed and accomplice to the process.

The lack of silver plated pieces found on sites from Upper Germany and Raetia can partially be credited to Augustus and his testament, the idea of imperial expansion $^{180}$, to maintain the current lands under the power

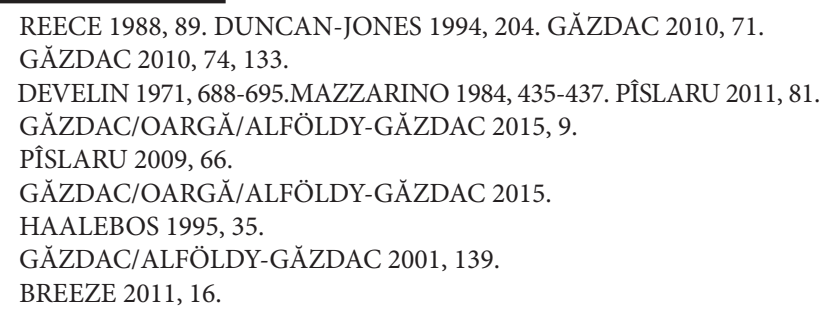

of Rome but to expand their influence and control beyond the physical borders onto neighboring factions ${ }^{181}$.

After almost a century from the death of Augustus, Tacitus writes his history of Rome where he also describes the Roman army and location of different units. Thus, he records "But chief strength was on the Rhine, as a defense alike against Germans and Gauls, and numbered eight legions." ${ }^{182}$

Clearly the upper region of the Rhine and Danube rivers was a thorn for Rome's presence in the area, since the region was very hard to supervise and acquired a lot of military manpower to keep it under control.

From the II century Rome's expansionistic policy was replaced with that of fortifying its borders, a vast number of defensive structures will be erected during the reign of Hadrian and Antonius Pius, followed by a demilitarization for the interior of the empire ${ }^{183}$.

Most probably the coin distribution of the empire was influenced by this change in policy, since during the I century most legions were situated in the Rhine area the coin distribution was centralized in the same region.

This leads us to the second motive, the possible mutiny risk produced by maintaining so many legions in the same place. As we can see from history, military commandants which were usually situated closer to Rome had the upper advantage in claiming the empty throne.

Thereafter by using silver plated coins, Roman authorities could reduce the needed quantity for issuing new coins ${ }^{184}$. In the case of plated silver coins discovered at Nijmegen none of them was dated before $70 \mathrm{BC}$, most of them were dated during the civil wars ${ }^{185}$ when large quantities of silver were used to obtain the loyalty of soldiers by combatants.

Hybrid coins remain a peculiarity of numismatics. As said before there is no pattern of distribution for this type of coins, being discovered randomly on archaeological sites and representing hardly between $1 \%$ and $3 \%$ from the total number of silver pieces. Also, many hybrid pieces were dated during the Severian dynasty, Fig. 159, but this is because there were a lot of coins issued in those times, thus a higher risk of making this kind of mistakes.

In the case of hybrid plated pieces, like the genuine hybrids, most of them were dated during the Severian period most likely as a side effect of the major debasement regarding silver coins, pieces manufactured with images belonging to issuers in times of which the coin used to be quality made. We have no sure way of dating these coins just their terminus post quem.

The occurrence of counterfeited coins is not specific to a certain region like Dacia or Pannonia but it's a general situation seen all along the Rhine and Danube frontiers. High quantities of silver plated pieces can only mean one thing, the issuing of this type of coins happened under the patronage and untold acceptance of the local Roman authorities.

\footnotetext{
81 BREEZE 2011, 16.

182 TACITUS, Annals, 4.

183 BREEZE 2011, 19.

184 CHANTRAINE 1982, 40-42.

185 HAALEBOS 1995, 35.
} 


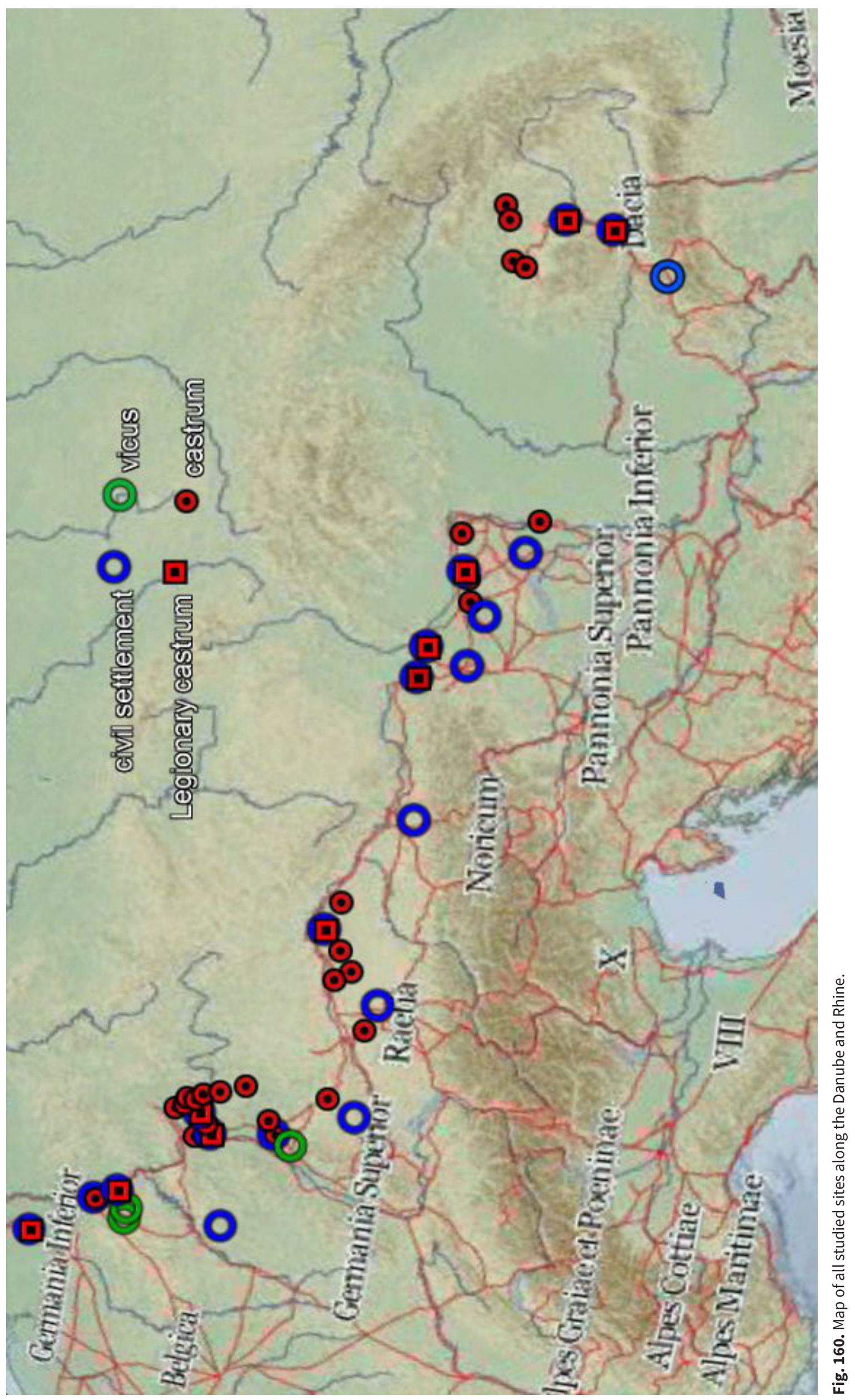




\section{REFERENCES:}

\section{Catalogues:}

AE 1978, 1995, 2005

CIL III, XIII

L’Année épigraphique, Paris.

Corpus Inscriptionum Latinarum.

FMRD 1960

Die Fundmünzen der römischen Zeit in Deutschland, Abteilung

I: Bayern. Band 1: Oberbayern (Berlin: Gebr. Mann).

FMRD 1962

Die Fundmünzen der römischen Zeit in Deutschland, Abteilung I: Bayern. Band 7, Schwaben (Berlin: Gebr. Mann).

FMRD 1963

Die Fundmünzen der römischen Zeit in Deutschland, Abteilung I: Bayern. Band 5, Mittelfranken (Berlin: Gebr. Mann).

FMRD 1964/3

Die Fundmünzen der römischen Zeit in Deutschland, Abteilung II: Baden-Württemberg. Band 3: Süd-Württemberg Hohenzollern (Berlin: Gebr. Mann).

FMRD 1964

Die Fundmünzen der römischen Zeit in Deutschland, Abteilung II: Baden-Württemberg. Band 4: Nordwürttemberg (Berlin: Gebr. Mann)

FMRD 1965

Die Fundmünzen der römischen Zeit in Deutschland. / Abteilung IV, Rheinland-Pfalz. Band 2, Pfalz (Berlin: Gebr. Mann).

FMRD 1970

Die Fundmünzen der römischen Zeit in Deutschland, Abteilung I: Bayern. Band 2: Niederbayern (Berlin: Gebr. Mann).

FMRD 1975

Die Fundmünzen der römischen Zeit in Deutschland, Abteilung I: Bayern. Band 6: Unterfranken (Berlin: Gebr. Mann).

FMRD 1978

Die Fundmünzen der römischen Zeit in Deutschland, Abteilung I: Bayern. Band 3, Niederbayern. Band 4, Oberfranken (Berlin: Gebr. Mann).

FMRD 1980

Die Fundmünzen der römischen Zeit in Deutschland, Abteilung II: Baden-Württemberg, Band 1, Norbaden (Mainz am Rhein: P. Von Zabern)

FMRD 1984

Die Fundmünzen der römischen Zeit in Deutschland. Abteilung VI, Nordrhein-Westfalen. Band 1/1, Stadt Köln (Berlin: Mann).

FMRD 1985

Die Fundmünzen der römischen Zeit in Deutschland. Abteilung IV, Rheinland-Pfalz. Band 5, Montabaur (Berlin: Gebr. Mann).

FMRD 1989a

Die Fundmünzen der römischen Zeit in Deutschland, Abteilung V, Hessen. Band 2/1, Darmstadt (Berlin: Gebr. Mann).

FMRD 1989b

Die Fundmünzen der römischen Zeit in Deutschland, Abteilung V: Hessen. Band 2/2, Darmstadt, Frankfurt am Main (Berlin: Gebr. Mann)

FMRD 1994a

Die Fundmünzen der römischen Zeit in Deutschland, Abteilung V, Hessen. Band 1/1, Wiesbaden (Berlin: Gebr. Mann).

FMRD 1994b

Die Fundmünzen der römischen Zeit in Deutschland, Abteilung V, Hessen. Band 1/2, Wiesbaden (Berlin: Gebr. Mann).

FMRD 2004

Die Fundmünzen der römischen Zeit in Deutschland. Abteilung IV, Rheinland-Pfalz. Band 3/3, Stadt und Reg.-Bez. Trier, Münzen ohne Funddort und/oder ohne Inventarnummer, 3021, 1-2 (Mainz: P. von Zabern).
FMRD 2006a

Die Fundmünzen der römischen Zeit in Deutschland, Abteilung IV, Rheinland-Pfalz. Band 1. Nachtrag 1, Stadt Mainz (Mainz am Rhein: P. von Zabern)

FMRD 2006b

Die Fundmünzen der römischen Zeit in Deutschland, Abteilung IV, Rheinland-Pfalz. Band 3/2, Stadt und Reg.-Bez. Trier, die Sog. Römerbauten (3003-3020) (Mainz am Rhein: Verlag Philipp).

FMRD 2006c

Die Fundmünzen der römischen Zeit in Deutschland, Abteilung VI, Nordrhein-Westfalen, Band 3/2, Stadt Neuss (Mainz am Rhein: Ph. von Zabern).

FMRD 2007

Die Fundmünzen der römischen Zeit in Deutschland, Abteilung IV, Rheinland-Pfalz. Band 3/4, Stadt und Reg.-Bez. Trier Stadt Trier, Strassen rechts der Mosel A-K,3022-3110 (Mainz am Rhein: P. von Zabern).

FMRD 2008

Die Fundmünzen der römischen Zeit in Deutschland, Abteilung VI, Nordrhein-Westfalen, Band 2/1, Reg.-Bez. Aachen (Mainz am Rhein: P. von Zabern).

FMRD 2010

Die Fundmünzen der römischen Zeit in Deutschland, Abteilung IV, Rheinland-Pfalz. Band 1. Nachtrag 2, Rheinhessen (Mainz am Rhein: P. von Zabern).

FMRÖ 1978

Die Fundmünzen der römischen Zeit in Österreich. Wien, Band FMRU I 9, (Wien: Osterreichische Akademie der Wissenschaften).

Die Fundmünzen der römischen Zeit in Ungarn, Bd. 1: Komitat Fejér (Bonn - Budapest: Habelt - Kultura Internat).

FMRU II

Die Fundmünzen der römischen Zeit in Ungarn, Bd. 2: Komitat Győr-Moson-Sopron, (Bonn: R. Habelt; Budapest: Kultura International Archaeolingua).

FMRU III

Die Fundmünzen der römischen Zeit in Ungarn, Bd. 3: Komitat Komárom-Estergom, (Berlin: Gebr. Mann).

\section{Ancient authors:}

TACITUS

Publius Cornelius Tacitus, Annales. I, 39,1.

TACITUS

Publius Cornelius Tacitus, Historiae, 4.

\section{Modern authors:}

\section{ANTIKEFAN.DE/REGENSBURG}

http://www.antikefan.de/staetten/deutschland/limes/ regensburg/castra.html, accessed March 2017.

BAATZ 1969

Baatz D., Zur Datierung des Bades am Limeskastell Stockstadt, (München: C. H. Beck).

BÖRNER 2002

Börner W., Wien-Vindobona, Legionslager-CanabaeAutonome Stadt in Der römische Limes in Österreich. Führer zu den archäologischen Denkmälern, 2, (Wien: Verl. der Österr. Akad. der Wiss).

BREEZE 2011

Breeze D. J., The Frontiers of Imperial Rome, (Barnsley: Pen \& Sword Military).

CASTRITIUS/CLAUSS/HEFNER 1977

Castritius H., Clauss M., Hefner L, Die Römischen Steininschriften des Odenwaldes (RSO), (S.1.).

\section{COH-II-RAET.DE}

http://www.coh-ii-raet.de/geschichte/abusina/index.html 
accessed March 2017.

CRAWFORD 1978

Crawford M. H., Ancient devaluation: a general theory, in Les „Dévaluations” à Rome époque Républicaine et Impériale (Roma, 13-15 November 1975), (Roma: École française de Rome), 147-158.

CÜPPERS 1990

Cüppers H., Die Römer in Rheinland-Pfalz, (Stuttgart: Thesis).

CÜPPERS 2005

Cüppers H., Die Römer in Rheinland-Pfalz, (Hamburg: Nikol).

DENKMALPFLEGE -SEITEN.DE

http://www.denkmalpflege-seiten.de/dtsch/cannstatt2. html, accessed March 2017.

DEPEYROT 2006

Depeyrot G., La Monnaie Romaine: 211 av. J.-C. - 476 apr. J.-C., (Paris: Errance).

DEVELIN 1971

Develin R., The Army Pay Rises under Severus and Caracalla and the Question of annona militaris, Latomus 30/3, 687695.

ECK 2005

Eck W., Köln in römischer Zeit. Geschichte einer Stadt im Rahmen des Imperium Romanum, (Köln: Greven).

FASOLD 1998

Fasold P, Ausgrabungen im teutschen Pompeji. Archäologische Forschung in der Frankfurter Nordweststadt, (Frankfurt: Imbescheidt).

FASSBINDER 2008

Fassbinder J., Neue Ergebnisse der geophysikalischen Prospektion am Obergermanisch-Raetischen limes, Neue Forschungen am Limes, (Stuttgart: Thesis).

FISCHER 2002

Fischer T., Noricum, (Mainz am Rhein: Philipp von Zabern).

FORUM/NIDA

http://www.forum-nida.de/nida/, accessed March 2017.

FRICKE 2007

Fricke M., Der Kastellvicus von Florstadt, Ober-Florstadt Funde der Grabung 2006, (Frankfurt am Main: Thesis).

GASPAR 2015

Gaspar R. B., Counterfeiting roman coins in The Roman Empire 1st.-3rd. A.D. Study on the roman provinces of Dacia and Pannonia, Journal of Ancient History and Archaeology, 2, 4, 2015, 31-74.

GĂZDAC 2010

Găzdac C., Monetary circulation in Dacia and the provinces from the Middle and Lower Danube from Trajan to Constantine I (AD 106-337), 2nd edition (Cluj-Napoca: Mega).

GĂZDAC/ALFÖLDY-GĂZDAC 2001

Găzdac C./Alföldy-Găzdac Á., The Roman law against counterfeiting between theory and practice: the case of Roman Dacia, Acta Musei Napocensis 38/1, 137-154.

GĂZDAC/COCIŞ 2004

Găzdac C./Cociş S., Ulpia Traiana Sarmizegetusa (ClujNapoca: Mega).

GĂZDAC/GAIU 2011

Găzdac C./Gaiu C., Arcobadara (Ilişua) (Cluj-Napoca: Mega).

GĂZDAC/GUDEA 2006

Găzdac C./Gudea N., Porolissum (Cluj-Napoca: Mega).

GĂZDAC/OARGĂ/ALFÖLDY-GĂZDAC 2015

Găzdac C./Oargă O./Alföldy-Găzdac A., It Was Supposed To Be Silver! The Scrap Coin" Hoard" Apulum VI (Cluj-Napoca: Mega).

GĂZDAC/SUCIU/ALFÖLDY-GĂZDAC 2009

Găzdac C./Suciu V./Alföldy-GăzdacÁ., Apulum (ClujNapoca:
Mega).

GUDEA 1999

Gudea N., Roman frontier studies: proceedings of the XVIIth International Congress of Roman Frontier Studies, (Zalău: County Council)

\section{GSCHWIND 2004}

Gschwind M., Abusina. Das römische Auxiliarkastell Eining an der Donau vom 1. bis 5. Jahrhundert n. Chr., (München: Beck).

HAALEBOS 1995

Haalebos J. K., Castra und Canabae: Ausbrabungen auf dem Hunerberg in Nijmegen 1987-1994, (Nijmegen: Katholieke Universiteit Nijmegen).

HAALEBOS 2000

Haalebos J. K., Romeinse troepen in Nijmegen, (Bijdragen en Mededelingen Vereniging Gelre).

HARL 1996

Harl K. W., Coinage in the Roman Economy, 300 B.C. to A.D. 700, (Baltimore; London: The John Hopkins University Press).

\section{HEINEN 1984}

Heinz Heinen H., Augustus und die Anfänge des römischen Trier in Rheinisches Landesmuseum Trier, (Mainz: Philipp Zabern).

HEINRICHS 2002

Heinrichs J., Civitas Ubiorum. Studien zur Geschichte der Ubier und ihres Gebiets, (Stuttgart).

HGV-NOERVENICH.DE

[http://hgv-noervenich.com/de/], accessed April 2017.

HORN 2003

Horn H. G., Die Römer in Nordrhein-Westfalen, (Stuttgart: Thesis).

HULD-ZETSCHE 1994

Huld-Zetsche I., Nida - Eine römische Stadt in Frankfurt am Main, (Stuttgart: Württembergisches Landesmuseum: Gesellschaft für Vor- und Frühgeschichte in Württemberg und Hohenzollern).

HÜSSEN 1995

Hüssen C. M., Römische Lager an der Donau in IngolstadtZuchering in Provinzialrömische Forschungen: Festschrift für Günter Ulbert zum 65. Geburtstag, (Espelkamp: Verlag M. Leidorf).

\section{JÄGER 1993}

Jäger U., Die Römer an der Donau. Bad Gögging, Kastell JONES 1992 Eining, (Treuchtlingen: Keller).

Jones B. W., The Emperor Domitian, (London: Routledge).

KEMKES 2006

Kemkes M., Der Limes. Grenze Roms zu den Barbaren, (Ostfildern: Thorbecke).

\section{KEMMERS 2006}

Kemmers F., Coins for a legion an analysis of the coin finds from Augustan legionary fortress and Flavian canabae legionis at Nijmegen, (Mainz am Rhein: Verlag Philipp von Zabern).

KORTÜM 1998

Kortüm K., Zur Datierung der römischen Militäranlagen im obergermanisch-raetischen Limesgebie in Saalburg-Jahrbuch, 49, (Mainz am Rhein: Von Zabern).

\section{KUNOW 2002}

Kunow J, Die Militärgeschichte Niedergermaniens in Die Römer in Nordrhein-Westfalen, (Hamburg: Nikol Verlagsgesellschaft \& Co).

\section{LIPPOLD 1979}

Lippold A., Regensburg 179 n. Chr. - Die Gründung des Lagers LIVIUS.ORG 
Livius.org/mogontiacum-mainz

http://www.livius.org/articles/place/mogontiacum-mainz/ accessed February 2017.

Livius.org/vindobona-vienna

http://www.livius.org/articles/place/vindobona-vienna/ accessed March 2017.

Livius.org/ novaesium-neuss

http://www.livius.org/articles/place/novaesium-neuss/ accessed April 2017.

LUDWIG 1997

Ludwig R., Kelten, Kastelle, Kurfürsten: Archäologie am unteren Neckar, (Stuttgart: Thesis).

MASPOLI 2014

Maspoli A. Z., Römische Militaria aus Wien. Die Funde aus dem Legionslager, den canabae legionis und der Zivilsiedlung von Vindobona, (Wien Phoibos-Verl).

MATTINGLY 1923-2007

Mattingly H., The Roman Imperial Coinage, vol. 10, (London: Spink).

MAZZARINO 1984

Mazzarino S., L'Impero romano, (Roma; Bari: Laterza).

MIGLBAUER 1997

Miglbauer R., „Es ist ein Kindlein uns geboren”: zur Ausstellung "Krippen und sakrale Kunst" Burg Wels, (Wels: Magistrat der Stadt Wels).

MÜLLER 1984

NUBER 1983

Müller G., Das römische Neuss, (Stuttgart: Thesis).

Nuber H. U., Die römischen Kastelle bei Hofheim am Taunus, Main-Taunus-Kreis, (Wiesbaden: Landesamt für Denkmalpflege Hessen).

OLDENSTEIN-PFERDEHIRT 1983

Oldenstein-Pferdehirt B., Die römischen Hilfstruppen nördlich des Mains. Forschungen zum Obergermanischen Heer I in Jahrbuch des Römisc-Germanischen Zentralmuseums, 30, (Römisch-Germanisches Zentralmuseum).

PÎSLARU 2009

Pîslaru M., The roman coins from Potaissa: legionary fortress and ancient town, (Cluj-Napoca: Mega).

PLEIADES.STOA.ORG

https://pleiades.stoa.org/places/109362, accessed March 2017.

PRAMMER 1989

Prammer J., Das römische Straubing: Ausgrabungen, Schatzfund, Gäubodenmuseum, (München: Schnell \& Steiner).

PREDA 2008

Preda C., Enciclopedie de numismatică antică în România, (Bucureşti: Editura Enciclopedică).

REECE 1988

Reece R., Numerical aspects of Roman coin hoards in Britain, in Coins and the Archaeologist, 2, (London: Seaby), 86-101.

REUTER 2004

Reuter M., Die römischen Kleinkastelle von HanauMittelbuchen und der Verlauf des östlichen Wetteraulimes unter Domitian in Limes Imperii Romani, (Bad Homburg: Römerkastell Saalburg Archäologischer Park).

RITTERLING 1909

Ritterling E., Das Kastell Wiesbaden in Der obergermanischraetische Limes des Roemerreiches, Abt. B 2.3b, Nr. 31, (Heidelberg: Petters).

RITTERLING 1925

Ritterling E., Legio (VI victrix) in Paulys Realencyclopädie der classischen Altertumswissenschaft (RE). Band XII,2, Stuttgart, 1925.

\section{ROECK 2005}

\section{RÜGER 1984}

Roeck B., Geschichte Augsburgs, (München: Beck).

Rüger C. B., Eine kleine Garnisonsgeschichte des römischen Neuss, in Das römische Neuss, (Stuttgart: Thesis).

\section{SCHÖNBERGER 1985}

Schönberger H., Die römischen Truppenlager der frühen und mittleren Kaiserzeit zwischen Nordsee und Inn, (Mainz am Rhein: Philipp von Zabern).

\section{SOMMER 1988}

Sommer C. S., Kastellvicus und Kastell: Untersuchungen zum Zugmantel im Taunus und zu den Kastellvici in Obergermanien und Rätien, (Stuttgart: Baden-Württemberg).

\section{STROBEL 1999}

Strobel K., Pseudophänomene der römischen Militär - und Provinzgeschichte, in Roman frontier studies: proceedings of the XVIIth International Congress of Roman Frontier Studies, (Zalău: County Council).

\section{TAUNUS-WETTERAU-LIMES/FRIEDBER}

http://www.taunus-wetterau-limes.de/index2.htm?friedber. htm, accessed March 2017.

\section{TAUNUS-WETTERAU-LIMES/WIESBADE}

http://www.taunus-wetterau-limes.de/index2.htm?wiesbade. htm, accessed March 2017.

\section{VICI.ORG}

https://vici.org, accessed February/May 2017.

\section{VONDROVEC 2003}

Vondrovec K., Die Antiken Fundmunzen von Ovilavis/Wels, (Wien: Österreichische Akademie der Wissenschaften).

\section{WALKE 1965}

Walke N., Das römische Donaukastell Straubing-Sorviodorum, (Bonn: Rheinisches Landesmuseum).

\section{WINKLER 1981}

Winkler G., Der antike Name von Wels, (Wels: Musealverein).

\section{WITTEYER 1999}

Witteyer M., Mogontiacum - Militärbasis und Verwaltungszentrum. Der archäologische Befund, in Mainz - Die Geschichte der Stadt, (Mainz: Zaberndruck).

\section{WÖRISHOFER/SIGG/SEITZ 2005}

Wörishofer G., Sigg A., Seitz R. H., Städte, Märkte und Gemeinden, in Der Landkreis Dillingen a. d. Donau in Geschichte und Gegenwart, (Dillingen a.d. Donau: Landkreis Dillingen). 